ROUTLEDGE RESEARCH IN RELIGION, MEDIA AND CULTURE

\title{
Media and New Religions in Japan
}

Erica Baffelli 


\section{Media and New Religions in Japan}

"Erica Baffelli's book breaks new ground by providing us with the first comprehensive analysis of the ways in which Japanese new religions use media forms to create marketable images of themselves and to construct images of their leaders and to transmit their teachings. Her study shows how the charismatic standing of leaders may be constructed and reinforced via media-ised processes, publications and rituals, and how new religions make use of spectacular, media-oriented rituals to attract new audiences. Yet she also shows that new religions at times have problems with new media, as her account of the ways in which they may struggle with the potentialities of the Internet shows. As such, this is a valuable study of importance to anyone interested in Japanese religions, new religions, and the media."

\section{-Ian Reader, University of Manchester, UK}

Japanese "new religions" (shinshūkyō) have used various media forms for training, communicating with members, presenting their messages, reinforcing or protecting the image of the leader and potentially attracting converts. In this book, the complex and dual relationship between the media and new religions is investigated by looking at the tensions groups face between the need for visibility and the risks of facing attacks and criticism through the media. Indeed, media and new technologies have been extensively used by religious groups not only to spread their messages and to try to reach a wider audience, but also to promote themselves as a highly modern and up-to-date form of religion appropriate for a modern technological age. In the 1980s and early 1990s, some movements, such as Agonshū, Kōfuku no Kagaku and Aum Shinrikyō, came into prominence especially via the use of media (initially publications, but also ritual broadcasts, advertising campaigns and public media events). This created new modes of ritual engagement and new ways of interactions between leaders and members. The aim of this book is to develop and illustrate particular key issues in the wider new religions and media nexus by using specific movements as examples. In particular, the analysis of the interaction between media and new religions will focus primarily on three case studies predominantly during the first period of development of the groups.

Erica Baffelli is currently a Senior Lecturer in Japanese Studies at the University of Manchester, UK. She is interested in religion in contemporary Japan, with a focus on groups founded from the 1970s onwards. Currently, she is examining the interactions between media and "new religions" (shinshūkyō) in the 1980s and 1990s and the changes in the use of media by religious institutions after the 1995 Tokyo subway attack. 


\section{Routledge Research in Religion, Media and Culture}

Edited by Jolyon Mitchell, David Morgan, and Stewart Hoover

1 Religion and Commodification

'Merchandizing' Diasporic

Hinduism

Vineeta Sinha

2 Japanese Religions on the Internet

Innovation, Representation, and Authority

Edited by Erica Baffelli, Ian Reader, Birgit Staemmler

\section{Religion and Hip Hop}

Monica R. Miller
4 Material Culture and Asian Religions

Text, Image, Object

Edited by Benjamin J. Fleming and Richard D. Mann

5 Religion, Media, and Social Change

Edited by Kennet Granholm, Marcus Moberg, and Sofia Sjö

6 Media and New Religions in Japan

Erica Baffelli 


\title{
Media and New Religions in Japan
}

\author{
Erica Baffelli
}


First published 2016

by Routledge

711 Third Avenue, New York, NY 10017

and by Routledge

2 Park Square, Milton Park, Abingdon, Oxon OX14 4RN

Routledge is an imprint of the Taylor \& Francis Group, an informa business

(C) 2016 Taylor \& Francis

The right of Erica Baffelli to be identified as author of this work has been asserted by her in accordance with sections 77 and 78 of the Copyright, Designs and Patents Act 1988.

The Open Access version of this book, available at www.taylorfrancis.com, has been made available under a Creative Commons Attribution-Non Commercial-No Derivatives 4.0 license.

Trademark Notice: Product or corporate names may be trademarks or registered trademarks, and are used only for identification and explanation without intent to infringe.

Library of Congress Cataloging-in-Publication Data

Names: Baffelli, Erica, 1976- author.

Title: Media and new religions in Japan / by Erica Baffelli.

Description: New York : Routledge, 2016. | Series: Routledge research in religion, media, and culture ; $6 \mid$ Includes bibliographical references and index.

Identifiers: LCCN 2015039821 | ISBN 9780415659123 (alk. paper)

Subjects: LCSH: Japan—Religion—1945-| Mass media in religionJapan. | Mass media-Religious aspects.

Classification: LCC BL2209 .B34 2016 | DDC 200.952/09045—dc23

LC record available at http://lccn.loc.gov/2015039821

ISBN: 978-0-415-65912-3 (hbk)

ISBN: 978-0-203-07503-6 (ebk)

Typeset in Sabon

by Apex CoVantage, LLC 
A Rosaria e Giuseppe 
This page intentionally left blank 


\section{Contents}

List of Figures and Tables $\quad$ ix

Acknowledgments xi

Note on Japanese Names, Terms and Transliteration xiii

Introduction: What Is This Book About?

1 Media and New Religions in Japan 14

2 The Importance of Media Engagements: Themes 44

3 Mediating (Buddhist) Rituals: Agonshū's Satellite

$\begin{array}{ll}\text { Broadcasting } & 68\end{array}$

4 Mediating the Leader's Image: Kōfuku no Kagaku's

Communication Strategies in the 1990s 89

5 New Religions and Offline/Online Interactions: Aum Shinrikȳo, Hikari no Wa and the Internet

Conclusions: Mediation Practices and Reception

Bibliography 153

Index 171 
This page intentionally left blank 


\section{Figures and Tables}

\section{FIGURES}

1.1 Seishin sekai (Spiritual world) section in a major bookstore in Tokyo.

1.2 "Kōfuku no Kagaku" section in a major bookstore in Tokyo.

1.3 The manga Metsubō no Hi ("Doomsday") published by Aum Shinrikyō.

1.4 Advertising material for Kōfuku no Kagaku's anime $\bar{O} g o n$ no Hō ("The Golden Laws"), 2003.

2.1 Agonshū Star Festival.

3.1 The two pyres at the Stars and Fire Rites Festival 1986/1987. 77

3.2 Participant at the Star Festival with loudspeaker, 1986/1987.

3.3 Members with headphones and two-way radios participating in the Star Festival 1986/1987.

3.4 Agonshū's advertisement poster, 2012.

4.1 Advertisement stickers for Ōkawa Ryūhō's books Nosutoradamusu Senritsu no Keiji " "The Terrifying Revelations of Nostradamus") and Arā no Daikeikoku ("Allah's Great Warning”) with the slogan "Jidai wa ima, Kōfuku no Kagaku" ("Now Is the Age of Kōfuku no Kagaku”), 1991.

4.2 Advertisement stickers distributed by Kōfuku no Kagaku, 1991.

5.1 Advertisement for Aum Shinrikyō's website.

5.2 Astral music available for download on Aum Shinrikyō's website.

5.3 Goods for sale on Aum Shinrikyō's website.

5.4 Aleph's official website.

5.6 Hikari no Wa's Net Dōjō. 
$\mathrm{x}$ Figures and Tables

5.7 Jōyū Fumihiro's blog.

6.1 Images of the anime Chōetsu Sekai (“Transcendental World").

\section{TABLES}

6.1 Videos on YouTube, August 15, 2008.

6.2 Videos on Niko Niko Dōga, August 15, 2008. 


\section{Acknowledgments}

Many colleagues and friends have supported me during the long process of writing this book. I am deeply indebted to Ian Reader for providing invaluable knowledge, suggestions, constructive criticisms and for reading through the entire manuscript before I submitted it for publication. Without his support and gentle prodding (and strict time management), this book would never have been completed.

My interest in religion in contemporary Japan and in media and religion started during my undergraduate and postgraduate studies, and I would like to thank Massimo Raveri and Jean-Pierre Berthon for guiding me and encouraging me to pursue this study.

Over the years, various people hosted me during my research trips in Japan, facilitated my access to material and to informants, shared stimulating discussions and invited me to present aspects of this study at conferences and seminars. I would like to express my gratitude to all of them. I would like to thank, in no particular order: Benjamin Dorman, Birgit Staemmler, Suzuki Masataka, Nakamaki Hirochika, Shimazono Susumu, Inoue Nobutaka, Tsukada Hotaka, Andrea Castiglioni, John Shultz, Mark Mullins, Elsa Pilone, Giulia Sepe, Levi McLaughlin, Stefania Travagnin, Fukamizu Kenshin, Kurosaki Hiroyuki, Lucia Dolce, Fabio Rambelli, Ioannis Gaitanidis, Tamura Takanori, Klaus Antoni, Paola Scrolavezza, Silvio Vita, Oda Tatsuya, Asakawa Yasuhiro, Suzaki Kayo and Hiro, Tsurumoto Akiko, Kawagiri $\bar{O}$ and Aki, Hayasaka Haruka, Paul Swanson, Yamaki Keiko, Okuyama Michiaki, Heidi Campbell, Uno Hitoshi, Fujita Shōichi, Chiara Ghidini, Monika Schrimpf, Jim Heisig, Matteo Segna, Matteo Rizzardi, Alessandro Verna, Koichiro Fukasawa, Toshio Miyake, Marcella Mariotti and Akira Tokuyasu.

I wish to thank the researchers at the Shūkyō Jōhō Risāchi Sentā (Religious Information Research Center) in Tokyo for patiently helping me collecting newspapers and magazine articles. I am grateful to the two anonymous reviewers who provided thoughtful comments and suggestions for improving the manuscript. I would also like to thank the members and representatives of the groups discussed in this book, who patiently replied to my questions and allowed me to attend events and ceremonies. Although their real names won't appear in this book, their contributions have been indispensable for my research. 


\section{xii Acknowledgments}

My colleagues and friends at the University of Otago supported me during my six-year stay in New Zealand and during the early stages of this project. In particular, I have been lucky to share this chapter of my life with Paola Voci, Cecilia Novero, James Harding, Mark Seymour, Gautam Ghosh, Will Sweetman, Gregory Dawes, Eric Repphun, Lena Tan, Carla Lamb, the Bayers, Ava Straw, Manu Straw, Emilio Novero, Grant, Alexandra Sweetman, Carrie Bouffard, Mary Griffiths, and Sandra Lindsay. I am also thankful to my colleagues at the University of Manchester for making me feel welcome: Jonathan Bunt (also for checking my translations from Japanese), Mara Patessio, Francesca Billiani, Aya Homei, Osen Kilic-Yildirim, Peter Cave, Sharon Kinsella, Nozomi Yamaguchi, Takako Iwakami and Aiko Otsuka. I thank all of them for their help. Obviously, any shortcomings are mine alone.

Financial support for researching and writing this book had been provided by numerous sources, including the Canon Foundation in Europe, the Japan Foundation, the Japan Society for the Promotion of Science, and a University of Otago Research Grant. Some sections of Chapter 4 have been previously published in my article "Mass Media and Religion in Japan: Mediating the Leader's Image", published in Westminster Papers in Communication and Culture 4/1. The section on "Hikari no Wa on the Internet" in Chapter 5 has previously appeared in my chapter "Charismatic Blogger? Authority and New Religions on the Web 2.0" published in Erica Baffelli, Ian Reader and Birgit Staemmler eds. Japanese Religions on the Internet: Innovation, Representation, and Authority. The brief introductions on Kōfuku no Kagaku and Aum Shinrikyō in Chapters 4 and 5 are based on my two chapters on these movements in Ulrich Dehn and Birgit Staemmler eds. Establishing the Revolutionary: An Introduction to New Religious in Japan. These articles and chapters have all been revised and updated here.

The final thanks go to my Italian big family, Giuseppe, Rosaria, Chiara, Gianlorenzo, Stefano, Ivan, Stella, Francesca Grande, Francesca Piccola and Nicola, and my Japanese family, Hiroshi, Kimiyo, Simon, Mario and Saya, for supporting me over the years. Finally, I would like to thank Toki, for supporting me in more ways that I can describe and for keeping me sane (and for the sushi), and Anna, for making me smile. This book is dedicated to my parents perché a loro devo tutto. 


\section{Note on Japanese Names, Terms and Transliteration}

All Japanese names are in standard Japanese order of family name first, followed by given name.

Long vowels are indicated by macrons $(\overline{\mathrm{o}}, \overline{\mathrm{u}})$, except for words and names commonly used in English (e.g., Kyoto, Tokyo).

When talking about religious institutions in Japan associated with its two main religious traditions, Shinto and Buddhism, I follow standard conventions and refer to Shinto institutions as "shrines" and Buddhist ones as "temples". 
This page intentionally left blank 


\section{Introduction}

\section{What Is This Book About?}

One night, during one of my first visits to Tokyo, I was waiting for the green light at the Shibuya pedestrian crossing. One of the busiest intersections in the world, it is surrounded by advertising signs and large video screens mounted on buildings overlooking the crossing, often showing the latest pop stars' music videos or advertising. One of these screens was showing rapidly moving images of young people playing different sports. I assumed this was the new advertisement of some well-known sport clothes brand, but at the end of the short video, the message "Possibilities are endless, Sōka Gakkai" (kanōsei wa mugendai, Sōka Gakkai) appeared on the screen. Sōka Gakkai is the largest new Buddhist organisation in Japan and advertisements of its publications frequently appear in newspapers and on television $^{1}$ and trains.

However, Sōka Gakkai's engagement with media and advertising is not unique among Japanese (new) religious organisations. In fact, it is just one example of the ways in which such movements seek to attract attention and get their messages across by using mass media strategies and advertising activities. For example, in July 1991, several thousand people gathered in the Tokyo Dome, a large baseball stadium in central Tokyo, to attend the "transformation" of Ōkawa Ryūhō, the leader of a religious movement called Kōfuku no Kagaku (literally, Science of Happiness, but now officially calling itself Happy Science in English), who proclaimed his true identity as a supreme deity called El Cantāre during a spectacular event and performance. In the months before the event, the group coordinated an intensive and expensive advertising campaign that prophesied the arrival of a new era with the slogan, "Now is the Age of Kōfuku no Kagaku" (Jidai wa ima, Kōfuku no Kagaku). Around the same period, Asahara Shōkō, the leader of Aum Shinrikyō, the group that later became notorious for committing the sarin gas attack on the Tokyo subway in 1995 and other atrocious crimes, was invited as a guest on TV talk shows, and his group, although sharply critical of modern society and media, was one of the first groups in Japan to engage with computer-based communication.

These are just a few examples of how Japanese "new religions" (shin$s h \bar{u} k y \bar{o})$ have in recent times used various mass media forms to publicise 


\section{Introduction}

themselves and get their messages across. This is not something that has only happened in the current era: since their emergence in the nineteenth century, Japanese new religions have been noted for their ability to use various media forms in such ways. While the movements that emerged in the nineteenth and early twentieth centuries were adept at using the printed page-often in the form of books, pamphlets and newsletters-in more recent times, as the above examples indicate, new religions have adopted newer media forms and technologies. ${ }^{2}$ In such ways, Japanese new religions appear to have kept pace with the times and with media developments and technologies. As this book will show, they have adjusted their strategies of self-promotion as media technologies have changed and developed in Japan. Lynch, Mitchell and Strahan have noted that "[...] it is increasingly difficult to think about religious phenomena in contemporary society without thinking about how these are implied with various form of media and cultural practices" $(2011,1)$ and studies of contemporary religion have argued that religious institutions have been implementing media logic to appeal to their audiences (Horsfield 2004). Although religion can always be seen as a part of mediated practices (De Vries 2001; Meyer and Moors 2005; Plate 2003; Stolow 2005), for some scholars, religion is progressively being subdued under the logic of media through the process of "mediatization" (Hjarvard 2008), ${ }^{3}$ that is, a process by which institutions and society are shaped by and dependent on media technologies and organisations. ${ }^{4}$ While the term "mediatization" has become widely employed by media and communication scholars, there has also been criticism of it and of the ways it has been used to suggest that religion in the present age is not only being affected, but deeply transformed or structured by mass media. In particular, critics have argued that mediatization is not necessarily a universal phenomenon (Hoover 2009, 136), nor necessarily a new and contemporary one (Morgan 2011, 138). Other scholars argue for a "mediation of religion" approach, asserting that the media have shaped religious practices in pre-modern contexts as well and that media and religion are interdependent. Stolow (2005) defines this approach as "religion as media":

Throughout history, in myriad forms, communication with and about 'the sacred' has always been enacted through written texts, ritual gestures, images and icons, architecture, music, incense, special garments, saintly relics and other objects of veneration, markings upon flesh, wagging tongues and other body parts. It is only through such media that it is at all possible to proclaim one's faith, mark one's affiliation, receive spiritual gifts, or participate in any of the countless local idioms for making the sacred present to mind and body. In other words, religion always encompasses techniques and technologies that we think of as 'media' [...].

As Carneiro (2015) has argued, according to the mediation approach, technology is not necessarily seen as modern media developed since the 
nineteenth century, but it is defined in a broader sense to denote "any human action that employs artefacts or techniques to attain some result within the environment or the human body itself" (Carneiro 2015, 9).

This book takes up these points, in particular the importance of considering the historical and cultural contexts, by discussing the key issues related to the media-religion nexus in the Japanese context.

In particular, my interest in this book is not on how new religions generally use media, but on how as new religions develop their media strategies in order to get their messages across to the wider populace, the strategies they adopt in turn impact the ways the movements develop. In particular, I will pay attention to such issues in the early stages of the formation of religious groups, since, as has been widely recognised, it is in their early periods of development that movements are at their most volatile. Therefore, the aim of this book is not to offer a comprehensive history of the use of media by Japanese new religions, but to identify key issues in the creation of media narratives by religious organisations in order to proselytise, communicate with members and create (and, at times, recreate or reshape) their image and in the relationship between those groups and the media. Thus far, there has been relatively little work done on how Japanese new religions use media communications or that considers the impact of media communications on new religions' practices, structures and belief systems. ${ }^{5}$ This book is intended to address this gap by using specific new religions as examples to develop and illustrate particular key issues in the wider new religions and media nexus.

Although this book is on Japanese new religions, it does not intend to claim that the Japanese case is unique. On the contrary, although recognising the specificities of the historical context and of each group, I identify key issues that are applicable to other groups and contexts where similar dynamics related to the ambivalent relationship between media and new religions occur. Indeed, media impacts on the definition of new religions and tensions in religious organisations between the use of media for achieving visibility and the negative consequences of media exposure have been discussed in other contexts, especially in relation to journalistic treatments of new religions (Beckford 1985, 1999; McCloud 2007; van Driel and Richardson 1988, 1997). Therefore, the selected themes: the importance of using media for increasing profile, improving image and recruitment; the impact on religious authority and on practices and ritual; the importance of branding, repackaging and regenerating media images, and finally, the risks connected to visibility, can contribute to discussions on the topic and provide a framework for the analysis of new religions-media dynamics in the larger context of the study of new religious movements. Religion and media, according to Hoover, are more and more connected $(2006,1)$, and to understand the processes of interactions between them, the historical context of these dynamics and the complexities of contemporary religions should be understood. 


\section{Introduction}

The term "media" commonly also refers to various forms (e.g., newspapers, radio, television, the Internet) through which information and views are expressed, generated and distributed, and in Japan, these forms have been highly important in the modern era. ${ }^{6}$ In the context of this book, I am also using the term "media" to refer specifically to media forms used by new religions. These include different media texts produced and distributed by new religions both internally, such as books published by in-house publishers (Chapter Four) and externally, that is, the use of industrial media by groups, such as, for example, the use of private satellite broadcasting companies (Chapter Three), the use of advertising agencies (Chapter Four) or the Internet and social media (Chapter Five). I will consider some media texts in detail in the context of the groups I use for my case studies, because they are particularly illustrative of the media technologies and image strategies those groups adopted in the early period of their formation. However, it would be problematic to focus just on one particular media form, as often groups implement a multimedia strategy, while the interconnections between different media are also important. For example, advertising campaigns are used to promote books that are used to advertise public media events, satellite broadcastings are advertised in magazines and on TV and new publications are advertised during the broadcasts and so on. Indeed, in the polymedia environment (Lynch, Mitchell, and Strhan 2011, 3), characterising contemporary Japanese society and making distinctions between different media (such as differentiated targets for specific publications or for animated movies, for example) is as important as interconnections and the overlap between them.

Finally, the role played by the media in both shaping public discourse on religion and in affecting how these movements are perceived and evaluated is also very relevant to the discussion. Although the focus of this book is more on the media texts produced and circulated by religious organisations, to the extent that an analysis of media representations of new religions ${ }^{7}$ is beyond the scope of this book, Chapter Four discusses media reactions to advertising campaigns and events organised by new religions, and the Conclusion analyses the reappropriation by online users of the materials created and distributed by a religious group.

Before introducing the structure of the book, some clarification regarding the term "new religions" is needed.

\section{NEW RELIGIONS}

The complex religious panorama in contemporary Japan includes numerous $^{8}$ groups that emerged from the nineteenth century and that have been labelled-according to the period of their development and the classification criteria adopted-with several terms, of which the most used by scholars are shinsh $\bar{u} k y \bar{o}^{9}$ (new religions), shin-shinsh $\bar{u} k y \bar{o}^{-10}$ (new-new religions), 
and shinreisei und $\bar{o}^{11}$ (new spiritual movements). ${ }^{12}$ Scholars have proposed different classifications and terminology for these groups over the last few decades in order to distinguish newly formed religious organisations from the so-called kisei shūkyō (institutionalised religions) or dentō shūkyō (traditional religions) (Inoue 1992; Shimazono 1992b; 2004), namely Buddhism and its various sects and Shinto. New religions developed in conjunction with the processes of modernisation and urbanisation, and in a recently published overview on these groups, Reader defines them as "the most significant organisational development in the Japanese religious context in modern times", and has noted that they are able to attract considerable numbers of members. ${ }^{13}$

The definition of new religions and their characteristics is rendered problematic by the fluidity and complexity of various groups and their affiliations (or lack of), and different phases of their development, formation and expansion. Just as the term shūkyo (religion) has been at the centre of several scholarly debates regarding the formation of the conceptual category of religion in Japan and its application to the Japanese context, ${ }^{14}$ so have the terms shinsh $\bar{u} k y \bar{o}$ and new religions been controversial, as the former was also used apologetically in the postwar period in order to grant new movements legitimacy (Thomas 2014), and the definition of "new religions" in other contexts does not necessary fit Japanese groups. ${ }^{15}$ Despite these limitations, however, the term new religions as a chronological category is used in this book because it remains the most viable English-language term to denote what we are focusing on. ${ }^{16}$

As has been previously mentioned, germinal forms of new religions appeared in the late Tokugawa period (1603-1867), and several phases of their development have been identified by scholars. Although there is no consensus about the exact dates of each phase, generally, the key periods are: the end of Tokugawa period and the beginning of the Meiji era (1868-1912), the 1920s and 1930s, the postwar period, the post "oil shock" period (post 1973) and finally, the post-1995 period (after the sarin gas attack). ${ }^{17}$ These phases of development also indicate that in the Japanese context, "new" does not necessary refers to first-generation new religions; some of these groups were established almost two centuries ago. The specific character of the "newness" in these religious groups lies in a combination of their historical period of formation, changes in relationships between members and in their organisational structure and in innovations regarding practices and doctrines. These changes must be understood in relation both with tradition-that is the main reference point for the doctrine of most groups-and with the specific historical context in which each of the groups developed.

Early studies (such as, for example, Thomsen 1963) listed a series of characteristics that were supposedly shared by new religions. Later studies criticised this approach and stressed significant differences in history, doctrine and practices and how the combination of these elements created different worldviews (Hardacre 1984). There are, however, some organisational and 
structural elements that could be identified and that are particularly relevant for the discussion of the relationship between media and new religions. First of all, there is the role of a charismatic leader who offers new teachings and practices, or a new interpretation of already existing ones, and a new path. The importance of the leader raises important issues related to the process of the legitimisation of leadership, which, depending on groups, could be founded in previous traditions (the new leader as the legitimate heir of a specific Buddhist school, for example) or through spirit possession ${ }^{18}$ and the channelling of deities and spirits. In some cases, the new leader claims to have received legitimation from the leader of another new religion, as, for example, Ōkawa Ryūhō (born 1956), the leader of Kōfuku no Kagaku, and Chino Yuko (1934-2006), the founder of Chino Shōkō (Chino True Law, also known as Panawēbu Kenkyūjo or the Pana Wave Laboratory), who both see themselves as legitimate heirs of Takahashi Shinji (1921-1976), founder of the GLA (God Light Association). Secondly, new religions have been defined as eclectic and dynamic, able to draw from different religious and philosophical traditions, and their affiliation can change over time. For new religions, it is often vital to demonstrate connections with an older, established tradition (such as a supposedly "true, original" Buddhism) while at the same time asserting that the previous teachings have been updated in order to fit contemporary society. Whelan calls the ability of new religions to incorporate different features into their own system as "survival syncretism", that is, "a self-conscious syncretism in which a religion assesses all of its potential competitive threats and attempts an energetic co-optation" (2007a, 389). This ability also allows groups to provide a plethora of practices and teachings for their members to choose from. They are also highly dynamic and can change quite radically over a short period of time, especially in the early stages of their formation. Their focus on this-worldly benefits has also been seen as an important characteristic of new religions, although this attention to practical benefits (genze riyaku) can be traced to other religious traditions and practices in Japan (Reader and Tanabe 1998).

Finally, from an organisational point of view, new religions are seen as particularly focused on proselytism efforts, also using the media and public events to promote their messages. The organisational structure of the new religions frequently includes teams specialising in public relations or media programming. Many groups have their own publishing houses that distribute their texts to ordinary retail bookshops, the latter often having special sections for groups with large numbers of publications (Ishii 1994). The use of media will be extensively discussed in the following chapters, but just to provide a couple of examples, Oomoto, a new religion founded in 1892 by Deguchi Nao, between 1908 and 1929 published 13 magazines and in 1920 , bought a newspaper that enabled it to get its message across to a larger national audience. Seichō no Ie, a group founded in 1930 by Taniguchi Masaharu, used the press as the main tool for proselytism, and its strategy of the publication and diffusion of its leader's books became a model for later 
groups. While Japan has not had anything directly akin to "televangelists", that is, Christian ministers that conduct sermons via television broadcasts, its new religions have maintained a high level of media presence. This has come mainly through advertisements in magazines and newspapers, in broadcasts on radio programmes and satellite television networks, and, more recently, through the use of websites and social networks. Furthermore, the enactment and fruition of religious rituals and festivals may be influenced by the presence of media, as, for example, when followers gather at the centres of their movements to watch videos, television and satellite broadcasts.

\section{CASE STUDIES IN THIS BOOK}

In this book, the analysis of the interaction between media and new religions will focus primarily on three case studies, and are set predominantly during the first period of the development of the groups being analysed (the 1980s for Agonshū, the late 1980s to early 1990s for Kōfuku no Kagaku, and post2007 for Hikari no Wa). The media strategies of such groups tend, of course, to change over time. My interest is to show how media forms have been essential at particular moments in the development of these groups, that is, when they were building their image and setting the basis of their teaching and doctrine. The choices of using particular media devices played a central role in the determining the success (with various degrees) of these groups and strongly impacted their public images for years to come.

While Kōfuku no Kagaku, Agonshū and Hikari no Wa are not the biggest new religious movements in Japan, they are significant examples in the discourse concerning media and religion for two main reasons. Firstly, they can be considered, for different reasons discussed in later chapters, very self-conscious groups when it comes to media communication strategies. Secondly, changes in their media strategies could be seen as correlated to the impact of the sarin gas attack in 1995. Kōfuku no Kagaku and Agonshū, although not directly involved in the crimes and violent actions, received significant attention and criticism after the sarin attack. Asahara Shōkō (born in 1955 as Matsumoto Chizuo), the leader of Aum Shinrikyō, was a member of Agonshū, a group founded in 1954 by Kiriyama Seiyu (born in 1921 as Tsutsumi Masuo), for a period of time and borrowed some of its teachings (Reader 2000a, 13; Shimazono 2001). Although Agonshū and its leader tried immediately to distance themselves from Aum after 1995 (Kiriyama 1995), the previous connection resulted in negative publicity. Kōfuku no Kagaku, founded in 1986 by Ōkawa Ryūhō (born in 1956 as Nakagawa Takashi) strongly criticised Aum Shinrikyō before 1995 (Kisala 2001a), but the rivalry between the two groups (Baffelli and Reader 2011), also fueled by media, as I will discuss later, created in the public mind the idea that they were similar, both having young leaders, a largely young and well-educated membership and an interest in being publicly visible. Finally, Hikari no Wa was founded 


\section{Introduction}

in 2007 by a group of ex-members of Aum Shinrikyō led by Jōyū Fumihiro (born 1962; previously a well-known Aum spokesperson) and it has, since then, been trying to distance itself from the previous group, a process that has implied a substantial reshaping of previous teaching and practices. ${ }^{19}$

As was mentioned above, the focus in this book will be on the early stage of development of religious organisations, although some reference will be made to later developments, but only in relation to the discussion of earlier media and image strategies. The necessity for these groups to present themselves as up-to-date and to continuously negotiate the relevance of the leader's message can become difficult to sustain over the long run. Second- and third-generation members are sometimes less involved and less enthusiastic. At the same time, the leader is no longer a young and novel "product" to be presented as innovative, while changes in organisational structures (the creation of a board of senior members, for example) may result in a more conservative approach toward implementing changes. As a consequence, what initially was a pioneering approach in media terms may be followed by less innovative, and even static, image strategies. This became evident with the introduction of the Internet and, later on, social media, and the fact that most new religions were very late or even cautious in using these new technologies (Baffelli 2011). As will be discussed later, this prudent approach to the Internet was also due to the impact of the sarin gas attacks and criticism toward new religions, as many groups learned that visibility is not necessarily always positive. However, it is also true that it is generally less controversial to implement changes or to include new technologies in the early stages of group formation, when teaching and practices are being created and often rapidly changed and reshaped, than later on, when a group has become more institutionalised, with more defined doctrines and ritual practices and, potentially, when members may be more resistant to changes. Therefore, the early stage of formation of new religions represents a dynamic and effervescent, but at the same time uncertain, moment where the processes of the media's impact on the creation of religious identity are particularly fascinating.

\section{STRUCTURE OF THE BOOK}

This book has been structured to provide a discussion of themes and key issues related to the interconnections between media and new religions, and an analysis of specific case studies.

In Chapter One, I highlight the dual and complex relationship between media and new religions. In particular, I look at the tensions groups face between the need for visibility through the use of media and the risks of facing attacks and criticism through other media. New religions use both internal media (that is, media technologies or institutions owned by the group, such as satellite broadcasting facilities or publishing houses) and external 
mass media (such as magazines and newspapers) as sources of legitimation and to reach a wider audience. They need external media such as newspapers and magazines because their internal media might be too limited in scope to broaden their visibility. However, this runs the risk that media exposure could have a negative impact on their public image. Yet without such exposure, they could be completely ignored by the larger public. Therefore, the media in general have played a central role in both defining new religions and creating interest about these groups. The chapter traces both the history of the treatment of new religions by the mass media and the communication strategies, mediated practices and media technologies used by new religions (press, radio, visual media, anime, manga, satellite broadcastings, websites and so on). The relationship between the media and religion changed on March 20, 1995, when the nerve gas attack on the Tokyo subway that I mentioned earlier occurred. Carried out by the new religion Aum Shinrikyō, the Aum Affair (Oumu jiken) is considered an important turning point in the relationship between new religions and society in Japan, and I argue that the media strategies of new religions in Japan must be examined in terms of the period before and the period after the events of 1995 .

Chapter Two concentrates on major themes within the image and communications strategies of new religions. First of all, media technologies can be employed by new religions to increase their profile and improve their image, and, ultimately, to support their propagation activities. Increasing numbers is a central issue for newly established organisations, as membership is also seen as proof that the organisation is a legitimate religion and not a dangerous group. Furthermore, active engagements with media technologies can project the image of a successful and up-to-date religion. Secondly, media exposure can impact on two important elements in the structure and organisation of the group, namely religious authority and practice. Mediated practices can reshape the relationship between a leader and followers, introducing new forms of interactions (such as online interactions), making the leader more accessible (for example, with live streaming of his/her lectures), or challenging his/her authority and legitimacy. Media technologies can also transform ritual practices by adapting them to the logic of media technologies or by transforming rituals into a spectacle and entertainment performance. Further themes are the role played by media forms in shaping the image of new religions (by creating, for example, standardised narratives of conversion stories) and repackaging this image in order to make the group look relevant and in tune with changes in society. Finally, visibility involves risks, as media exposure can lead to severe criticism. Reactions to criticism can severely impact the future of a religious organisation. Some groups are able to use media attention and even criticism to strengthen their identity, while others are unprepared to respond to media attacks and may never recover from the damage to their image.

Chapter Three investigates the emergence of new forms, contexts and experiences of rituals mediated by the media. In particular, the chapter 


\section{Introduction}

addresses the satellite transmission of Agonshū rituals and the impact that new media have had on religious practices and rituals. The analysis will discuss how the ritual is recreated and extended by the media and also how "sacralised screens" can be a means to spectacularise but also internalise religious rituals. Agonshū is a striking example of a new religion that came into prominence especially via the use of media forms, initially publications, but also dramatic rituals broadcast across Japan. Agonshū engaged in a process of "spectacularising" its practices in ways that attracted a following and also public attention. Also, Agonshū was a pioneer in creating new modes of ritual engagement and community, by transmitting its rituals visually and aurally to members in distant places, thereby creating a form of "mediated community" that enabled followers in different parts of Japan to participate together in a single ritual.

Chapter Four examines Kōfuku no Kagaku's communication strategies in the 1990s. It focuses especially on the two-year period between 1991 and 1992 when the sacralisation of the leader Ōkawa Ryūhō brought about through a massive publicity campaign can be contrasted with the attempt at delegitimisation carried out by the press in the same period (the so-called Kōdansha Friday Affair). Ōkawa is an interesting example of a religious leader whose status is particularly bound to his uses of media, in particular, printed media. The success of the group in the early 1990s was determined by a combination of savvy management strategies, combined with a flexible doctrine and an efficacious use of media strategies-including constant rewriting and republishing of texts according to doctrinal changes, advertising campaigns and large events centred around the leader.

Chapter Five is concerned with the use of computer-based communication by Aum Shinrikyō, and in particular with the use of websites and social networking sites by its splinter group, Hikari no Wa. For Hikari no Wa, the Internet is an important tool for reshaping its identity, claiming its separation from the violent past of Aum, communicating with members and presenting its reformed teachings. However, the Hikari no Wa case should be understood in the context of its specific circumstances. Because of its relationship to Aum, Hikari no Wa did not have access to media other than the Internet. Therefore, Internet-based interaction is vital for a group that is attempting to rebuild its credibility and legitimacy, but that is haunted by a traumatic past and has very limited access to mainstream media.

In the Conclusions, I suggest that the relationship between media and religion is not constant and stable, but shifting in a constant process of negotiation. In particular, users' reappropriation and reproduction (especially online) of publicly available materials produced by new religions can transform them completely from a tool for propagation to an object of ridicule that potentially challenges and undermines religious authority. Such appropriation practices also demonstrate the dualistic nature of the media-religion relationship that has been discussed in the other case studies and indicate how the Internet can potentially create new challenges for religious organisations. 


\section{NOTES}

1. In 2006-2007, for example, Sōka Gakkai launched a TV advertising campaign with the slogan "A new future for you, Sōka Gakkai" (anata no, ashita wo, atarashiku, Sōka Gakkai).

2. One of the first movements to use print media for propagation activities was a group called Oomoto, which established its first magazine in 1914 (Dorman 2012a, 45-65; Stalker 2008).

3. The field of the study of religion and media expanded from the mid-1990s onwards with the emergence of phenomena such as televangelists in North America. Subject areas include the new and evolving field of media, religion and culture (Clark 2007; Hoover 2006; Hoover and Clark eds. 2002; Hoover and Lundby eds. 1997; Lynch, Mitchell, and Strhan eds. 2011; Mitchell and Marriage eds. 2003; Morgan ed. 2008), audience (Stout and Buddenbaum 1996; 2001), popular culture (Forbes and Mahan 2005), critical studies (De Vries and Weber eds.2001) and anthropology (Meyer and Moors 2005). For overviews of the field, see Mahan 2014; Stout 2012; Stout and Buddenbaum 2002.

4. For synoptic accounts on mediatization, see Couldry and Hepp (2013); Lundby (2009).

5. Early works on the use of media by new religions in Japan and on representations of new religions in media include Ishii (1989) and two comprehensive sections of the Shinshükyō jiten (Encyclopaedia of New Religions) edited by Inoue et al. 1994 (one article is by Ishii, 322-31 and the other by Inoue, 516-58). A general overview in English on new religions and media is Inoue (2012). Some works have focused on use of media by Aum Shinrikyō, such as Fukamizu (1994; 1996); Watanabe (2005, on the group use of computer-based communication); Gardner (2008, on manga and Aum's views of media). In 2011, Inoue and the Religious Information Research Center published a comprehensive volume including 21 chapters on material produced by and on Aum Shinrikyō. Dorman's Celebrity Gods (2012a) investigates the relationship between media and new religions in the postwar period, while Stalker's Prophet Motive (2008) looks at the role played by media in the development of Oomoto in the 1920s. Thomas (2012) includes some discussion on anime and manga produced by new religions. There are also a few book chapters and articles that looked at related topics, such as Agonshü's use of spectacular events and media technologies (Reader 1991), GLA-mediated practices (Whelan 2007b), Konkōkyō and Seichō no Ie's use of radio (Enomoto 2006) and Kōfuku no Kagaku's anime (Tsukada 2010). See also Berthon (2011). Finally, several studies have focused on computer-mediated communication, including Baffelli 2000; Baffelli 2010; Baffelli, Reader, and Staemmler 2011; Ess, Kawabata, and Kurosaki eds. 2007; Fukamizu 2007; Giambra 2015; Ikegami and Nakamaki eds. 1996; Inoue ed. 2003; Kienle and Staemmler 2003; Kokusai Shūkyō Kenkyūjo ed. 2000; Kurosaki 2006; 2007; Kurosaki ed. 2000; Kurosaki, Hoshino, and Terazawa 2009; Tamura $1998 ; 2005$.

6. For example, during the 1980s and 1990s, that is the period when new religions examined in this book expanded. During that time, 72 newspapers were published each day in Japan and 90per cent of the public read newspapers on a daily basis (Foreign press centre 1990, 13; Nihon Shinbun Kyōkai 1994; Pharr and Krauss 1996, 4). Four newspapers had a circulation of more than two million copies (Yomiuri, Asabi, Mainichi and Sankei) and several local and regional newspapers were also distributed. A survey conducted in 1989 


\section{Introduction}

by NHK (Nippon Hōsō Kyōkai, in English, Japan Broadcasting Corporation) showed that there were more television sets than homes in Japan and on average viewers, spent three hours and 23 minutes daily watching TV (Foreign Press Centre 1990, 48). However, printed media and in particular newspapers enjoyed prestige and higher credibility ratings than TV news (but a majority of Japanese trusted both, Nihon Shinbun Kyōkai, 1992, 32; 36-37).

7. On the topic, see Dorman (2012a); Dorman and Reader (2007); Thomas (2012).

8. It is very difficult to estimate the exact numbers of new religions. The Federation of New Religious Organizations of Japan (Shin Nihon shūkyō dantai rengōkai, which is abbreviated shinshüren), includes 39 organisations, but many new religions are not affiliated with the Federation. Furthermore, legal registration under the Japanese Religious Corporation Law (Shūkyō Hōjin Hō) is not compulsory and some groups may decide not to register (or they are not allowed to, as in the case of the splinter groups from Aum Shinrikyō). The Shinshükyō jiten (Encyclopaedia of New Religions, Inoue et. al. 1994) includes the profiles of over 300 groups, and similar numbers are confirmed by the database of the Religious Information Research Center in Tokyo (http:// www.rirc.or.jp). For further discussion on numbers, see Astley (2006, 96-98); Reader (2015); Staemmler and Dehn $(2011,5)$.

9. In Japanese, shükyō is the standard term for religion, and shin simply means "new".

10. Nishiyama Shigeru first used the term shin shinshūkyō (New New Religions) in 1979 (Nishiyama 1979, 33-37). The journal Shūkyō to Shakai vol. 3 in 1997 published a debate regarding the validity of the term shin shinshükyo with a critical article by Inoue (1997) and responses from Nishiyama (1997) and Shimazono (1997a).

11. "new spiritual movements" is used to define the Japanese version of the New Age, and usually refers to a network of practitioners and practices not structured as a religious group. These can include informal gatherings of people sharing the same interests who occasionally attend the same ceremonies or activities. In these loose affiliations, there is rarely a well-defined leadership structure and these networks rarely form their own rites or doctrines. For a discussion of the term, see Shimazono (1992a).

12. Initially, more pejorative terms were used to indicate "new religions", such as ruiji shūkyō (quasi religions) or shinkō shūkyō (newly arisen religions, but implying derogatory nuances of superficiality, Astley 2006; Murakami 1980). The latter term is still often used in media when referring to new religions. After the 1995 sarin gas attack, the term karuto (cult) started to be used to indicate potentially dangerous or unusual religious groups.

Shimazono also discussed the term shinshūkyo in relation to the terms shūgō shūkyō (syncretic religions) and minzoku shūkyō (popular religions). The former understands new religions in a tripartite system of institutionalised religions, popular beliefs and syncretic religions. The former, however, was considered too generic (see Shimazono 1981 and 1987). Inoue (1999; 2000; 2012) has proposed the term haipa $\bar{a}$ shükyo (hyper-religions) to define groups established since the 1970s to indicate the tendency in these groups to adopt teaching and rituals from outside the Japanese tradition and to use language from the natural sciences and psychology. Finally, after the 1995 sarin gas attack, the image of new religions (and of religion in general) has become increasingly negative (Baffelli and Reader 2011). As a consequence, some groups avoid overt religious rituals or language or reject the term shinshükyo in order not to be associated with dangerous "cults". On terminology, see also 
Inoue (1997); Reader (2015); Shimazono (1994); Staemmler and Dehn eds. (2011).

13. It is often quite difficult to obtain precise figures regarding members, due to different ways of assessing membership figures by groups that tend to inflate numbers. Some scholars have estimated than between 10-20 per cent of Japanese population are members of a new religion. For further discussion on membership and figures, see Astley (2006, 96-98); Hardacre (1986, 3); Inoue (1992, 9); Kisala (1999, 2); Reader (1991, 195-196 and 2015); Shimazono (1992b, 106); Staemmler and Dehn eds. (2011, 5-6). Official figures submitted by religious institutions are published annually by the Agency for Cultural Affairs in the Shükyō Nenkan (Religions Year Book), now also available online at: http://www.bunka.go.jp/tokei_hakusho_shuppan/hakusho_nenjihokokusho/ shukyo_nenkan/. Accessed July 20, 2015.

14. See, for example, Fitzgerald (2000); Isomae (2003; 2005); Josephson (2012); Maxey (2014); Pye (2003); Reader (2004; 2005b); Shimazono and Tsuruoka eds. (2004).

15. For a debate on different criteria used to define "new religious movement", see the series of articles in Nova Religio by Barker (2004); Bromley (2004); Melton (2004); Reader (2005a).

16. The term is generally used in scholarship on Japanese religions. See Astley (2006); Hardacre (1986); Inoue et. al (1994); Prohl (2012); Reader (1991); Staemmler and Dehn (2011).

17. For a discussion on the historical phases of development of new religions, see Astley (2006, 95-96), Hardacre (1986, 4); Kisala (1999, 3); Nishiyama and Ōmura eds. (1998); Reader (1991, 195; 2015); Shimazono (1992b, 42-48); Staemmler $(2011,13-15)$.

18. On the role of spirit possession in new religions and charismatic founders, see Davis (1980); Ooms (2010); Staemmler (2009).

19. The analysis in this book is based on fieldwork and interviews I have conducted with the three groups over an extended period of time: since 2003 for Kōfuku no Kagaku, since 2005 for Agonshū and since 2008 for Hikari no Wa. 


\section{Media and New Religions in Japan}

\section{THE IMPORTANCE OF BEING “VISIBLE”}

In a scene of the documentary $A$ by Mori Tatsuya, ${ }^{1}$ Araki Hiroshi-acting as Aum Shinrikyō's spokesperson after its leader and other prominent members were arrested following the 1995 sarin gas attack-looks at the camera and says to Mori that he wants him to film and record "them" accurately (chanto kiroku ni tottemoraitai). Aum didn't have, he continues, a tradition of recording its activities; therefore, members' communal lives were not documented. And, he argues, even if members had produced records of their activities, people would have not believed them. ${ }^{2}$ Therefore, he wants people who are able to do so to see this (chanto mieru hito ni mitemoraitai).

Araki's words perfectly summarise the interdependence and the complex relationship between newly formed (and, at times, controversial) religious organisations and media in Japan. The leader of Aum Shinrikyō, Asahara Shōkō, and other members often appeared on television shows before the 1995 sarin gas attack (Gardner 2001; Kojima 2011). The unusual personality of the leader, and the fact the some members were young and successful but renounced their careers, donated their personal belongings, and left their families to join a communal life and to participate in extreme ascetic practices attracted media attention. Aum practices and lifestyles also raised many controversies over issues such as communes, brushes with the law and conflict with other groups, in particular with Kōfuku no Kagaku (Baffelli and Reader 2011; Dorman 2012a, 11; Reader 2000a; Watanabe 1997, 37-38). After the sarin gas attack, Aum was again used by the media to create an audience through the diffusion of stories of supposed brainwashing techniques used by new religions, and obsessive reportages on the group's unusual training practices and teaching. Members' daily activities too, from their dietary restrictions to their religious practice, were the subject of intense media scrutiny and were portrayed as unconventional, bizarre and weird. Aum itself initially enjoyed media exposure and actively used the media to respond to its detractors and to promote its image, even in the period immediately after the sarin gas attacks, when Aum representatives and Jōyū Fumihiro, the group's spokesperson, frequently appeared in 
press conferences and interviews to deny involvement in the crimes (Gardner 2001, 139; see also Chapter 5 in this volume). At the same time, Aum used media forms by producing numerous publications, videos and tapes with its leader's sermons and teachings to be used by members during their practices. However, as Araki noted, the daily life reality of members and the banality of their daily routine, which included ascetic training and religious practices, but also cooking, cleaning, laughing and talking together, were not recorded.

Although distinctive, due to the violent trajectories followed by the group and its consequences, the ambivalent and problematic relationship between Aum Shinrikyō and the media is not unique. In the case of other new religions too, as will be discussed in further detail later, the representations of groups in external media (that is, media texts produced by agencies external to the group, such as mainstream media or, at times, media produced by other religious organisations) tend to be constructed to criticise or ridicule members and make them appear as dangerous, eccentric, metaphorical "others" 3 that are therefore differentiated from the rest of society or from other religious organisations. At the same time, internal media (that is, media texts, such as magazines, videos, books and so on produced by the religious group itself) tend to present an image of harmony, and of highly committed and loyal members, while emphasising the role and importance of the leader. As Araki notes, very little is available, in both the material produced by religious groups and by external media, about the daily life activities of members and their personal histories and experiences. Paradoxically, publications by new religions frequently focus on personal accounts from members, their personal experiences in the group, and conversion stories. However, these accounts tend to be standardised and very similar to each other, creating a uniform narrative basis to strengthen a particular image of the group. These internal narratives, as well as external representations of members, tend to present the group as a uniform entity, while ignoring individual understandings of the teaching and the continuous negotiation (and, at times, dissent) between the leader's authority and the views of followers.

Araki's words also raise another issue. Material produced by religious organisations is often seen as biased. In the above-mentioned example, if Aum members themselves had filmed their lives in the group, it would have been difficult to persuade viewers that what was presented was an accurate account of daily life in the group. Viewers may think that the group is hiding something, and, obviously, the group will have an interest in only presenting a positive image of itself, avoiding showing potentially controversial practices or contradictory statements about doctrine. However, visibility is essential for newly formed organisations that have to make themselves known to the larger public, and that need to present a counterargument to their detractors' criticisms. As a consequence, groups are pressured to rely on external media to present a reliable account of themselves, that is, they are forced to depend on an external, non-member's gaze and point of view to present their teaching, while at the same time advising members that 
non-members and external media often misunderstand their practices and teachings. ${ }^{4}$ In an interesting conundrum, the documentary scene showed how Aum members had to rely on media, through Mori's work, not only to attempt to show to the general public that the idea created and amplified by the media themselves of Aum's members as "evil" and "weird" was inaccurate, but also to have a record of their own existence, at a time when most of the group's buildings and facilities were being confiscated and destroyed.

This contradiction seems unable to be resolved, as material produced by religious groups tends to be apologetic and didactic, making the reader wary that they are just attempts at proselytism. At the same time, the need for visibility by such groups has raised issues of media "objectivity", as journalists, TV show producers and presenters, video directors and so on are extremely cautious when presenting materials about religious groups, to avoid being accused of partisanship or even of being supporters of a particular group. Objectivity, of course, cannot exist. In the two documentaries he filmed about Aum members, $A(1998)$ and $A 2^{5}$ (2001), and in his publications about the group (in particular, A3, 2010) Mori Tatsuya decided to take a different approach in filming Aum members compared to other Japanese mainstream media that tended to represent the group as an "evil cult" and members as "brainwashed" (Gardner 2001; Reader 2000a). He wrote a letter to Aum's spokesperson asking for the group's permission for him to enter its facilities and to film members' daily lives, and he decided not to add any commentary to his movies. Therefore, Mori obtained privileged access to the group and members' private lives. As a consequence, members shared with him personal feelings and emotions, while his ability to keep a distance was questioned when members asked him to help them by providing his filming of their confrontation with authorities after a member was arrested (as discussed later in this Chapter). ${ }^{6}$ Mori also had to pay a high price for his decision, resulting in his movies being ignored by mainstream media and the Japanese public (Gardner 2001; Mori 2000), in a sense reinforcing the widespread perception of incommunicability between Aum members and the external world.

Such problematic issues and dilemmas need always to be borne in mind when examining the strategies of new religions in the context of the media. Before discussing media strategies implemented by new religions, it is important to briefly contextualise how the general media has perceived these groups. Although this is not the main focus of the book, it needs to be understood as the framework within which new religions' media strategies operate. Furthermore, the analysis of the relationship between shinshükyo (new religions $)^{7}$ and society in contemporary Japan needs to take into account the role of the media in both shaping public discourse about religion and in (re)creating religious groups' images and identities. As noted by Dorman, the relationship between the media and newly founded and emerging religious groups can been described as a "mixed blessing" (Dorman 2005a): media technologies and, at times, media attention may support the development of some new religions, but media scrutiny also can become a major destabilising 
factor for some groups. As Hoover notes, "it is through the media that much of contemporary religion and spirituality is known" $(2006,1)$; indeed, the media can affect our ways of interpreting, understanding and representing religion.

\section{MEDIA VIEWS ON NEW RELIGIONS}

As previous studies have noted (Dorman and Reader 2007; Hoover 2002), it is problematic to treat media and religion as completely separate entities, and the different layers of interconnections between the two spheres should be explored. In the context of Japan, it is important to note how mass media organisations and new religions developed around the same period and, as a consequence, how the two spheres became part of the same process of negotiating their new role(s) in the society. This resulted in a complex and ambivalent relationship between media and new religions that it is still visible nowadays and also in an overlap and in similarities in the language, image strategies and imagery shared between them.

Since the late nineteenth century, the media, in particular printed media, has become an important source of information regarding new religions in Japan. During the Meiji period, the development of newspapers, magazines and journals was encouraged and, in 1925, radio broadcasting started. ${ }^{8}$ The media were under strict control and censorship, ${ }^{9}$ especially concerning such topics as the emperor and the imperial family. Religious groups that were perceived as potentially "undermining or offering alternatives to the model of national and cultural identity centered on the emperor" (Gardner 2005, 155) were put under severe scrutiny by the authorities and described as "pseudo-religions" (ruiji shükyō) and "heresies" (jakyō). ${ }^{10}$ The press played a central role in defining religious orthodoxy (Dorman 2012a, 25; and, more generally, Chapter One; Sawada 2004, 236), repeating the terms used by political authorities and labelling new religions as "repugnant, unwholesome phenomena that threatened the moral fiber of the Japanese nation" (Sawada 2004, 256) and attacking them on the based on their supposed "immorality" (Dorman 2012a). The media contribution to campaigns against new religions (Gardner 2005, 155) resulted in harsh criticism of these groups and their practices. The press was even stronger that the state in its condemnation, in order to show its role as protectors of national ideals (Dorman 2012a; Stalker 2008). An early example of this attitude is the publication in Chüo Shinbun in 1896 of 150 installments attacking Tenrikyō (Inoue 1992, 57; Stalker 2008, 84)—one of the earliest new religions, founded in 1838 by Nakayama Miki (1798-1887) and one of the largest movements at the time-which was condemned as "immoral heresy" (inshi jakyō). ${ }^{11}$ Tenrikyō received criticism from different newspapers from 1883 to 1902 (Inoue 1992, 56-64; Sawada 2004, 236-38; Stalker 2008, 84). 
The most significant example of the role played by those assuming the position of "public moralist" in the late nineteenth century in defining religious orthodoxy (Sawada 2004, 236) and also of the earlier tensions between media and new religions is probably the case of a short-lived group called Renmonkyō. Established by Shimamura Mitsu (1831-1904) in 1883, in the late nineteenth century, Renmonky $\overline{0}^{12}$ became one of the largest new religious organisations in Japan. The adherents were attracted by Shimamura's teachings, which included aspects of Nichiren Buddhism, and by her practices based on "holy water" (shinsui), which was believed to have healing properties for different illnesses, including cholera (Dorman 2012a; Takeda 1991). In 1894, Renmonkyō and its leader became the object of a defamatory campaign by Yorozu Chōhō, a popular newspaper established in 1892. The first derogatory articles appeared in February 1894 and for about nine months, critical articles about the leader and its followers were published, including a ninety-four installment series entitled, Inshi Renmonkyokai ("The Immoral Religion Renmonkyō”, Inoue 1992, 49; Sawada 2004, 246; Takeda 1991). In these articles, the leader was accused of personal immorality, of being engaged in fraudulent practices and of illicit healing (Dorman 2012a, 37; Sawada 2004, 256), accusations that, as will be discussed in Chapter Two, are often used in media attacks on new religions. ${ }^{13}$ Furthermore, Yorozu Chōhō and other newspapers accused Renmonkyō of heterodoxy and heteropraxis and of being anti-Shinto. ${ }^{14}$ In doing so, the newspaper subtly criticised the legal provision of freedom of religion as one of the factors that contributed to the emergence of "dangerous" groups (Dorman 2012a, 36), and assumed the role of the defender of religious orthodoxy. At the same time, criticisms toward Renmonkyō (and other new religions) were echoed in publications by other religious organisations, such as the Buddhist paper Meikyō Shinshi (Sawada 2004, 250), which called for groups like Renmonkyō to be dissolved by the Ministry.

Therefore, the attacks on Renmonkyō can be seen as representative of how new religions were used for power negotiations and definitions of religious orthodoxy between different actors in the Meiji period, such as government authorities, the emerging media and other religious institutions. The actors involved were concerned about the ability of emerging religious groups to attract adherents from different social groups that could result, in the case of Buddhist leaders, in the potential loss of their own parishioners (Dorman 2012a, 28; Sawada 2004, 250) and about devotion to the leader that could potentially challenge established religious and secular authorities. The case of Renmonkyō is also emblematic because of how the group responded to the crisis. As will be discussed in Chapters Two and Four, different responses to media attacks have resulted in significantly different consequences for the survival of the religious group involved in such conflicts. It is also important to note, however, that similar strategies have had dissimilar outcomes in different periods and circumstances. Renmonkyō responded by sending rebuttals to the newspapers that attacked it and demanding the retraction of 
their accusations (Takeda 1991). Subsequently, the group placed announcements in several newspapers, including Yorozu Chōhō, explaining its decision to start legal action against Yorozu Chōhō and its fabricated reporting. The civil suit was filed in April and, following a temporary injunction on publication issued by the Tokyo Court of Appeals, Yorozu Chōhō suspended its derogatory series (Takeda 1991). However, the decision by the group to take legal action, instead of refuting the criticism on doctrinal grounds, was highly criticised as not appropriate for a religious group and, ultimately, resulted in general reinforcement of the perception that Renmonkyō was a "bogus religion" (inshi jakyō $)^{15}$, Takeda 1991). The numbers of adherents dropped, leading to a rapid decline of group's activities.

In the period of Japan's rising militarism and involvement in campaigns in China from 1931 onwards and culminating in its involvement in World War Two, religious organisations that were not affiliated with one of the thirteen legally approved Sect Shinto (kyōha shintō) sects were considered suspicious and closely monitored by the authorities (Murakami 1980). This increased control by the authorities resulted in some groups, such as Oomoto, ${ }^{16}$ being suppressed (Murakami 1980). Morioka $(1994,309)$ argues than in general, the press uncritically embraced the charges made by the police and in doing so helped to justify the government's actions. However, Dorman (2005c, 61-62) argues that there was no unanimity in journalists' reports about accusations against new religions. He shows, for instance, that some articles criticised (at least until mid-1930s) the accusations made by the authorities, without, however, questioning the severe scrutiny on new religions or the dominant depiction of them as problematic.

In the postwar period, the media continued their role in shaping and defining the image of new religions, assuming the role of protector of social norms and denouncing groups that were seen as potentially antisocial or a threat to social stability. Expressions such as "rush hour of the gods" (kamigami no rashu awa $)^{17}$ appeared in the press to indicate an apparent increase in the numbers of new religions following the introduction of the Religious Juridical Persons Law in $1951 .{ }^{18}$ New religions were described in terms that made them sound transient and ephemeral, as "sprouting like bamboo shoots after the rain" (ugo no takenoko no yōni), (Dorman 2012a, 5), and media reporting on them in the immediate postwar period tended to be very critical (Dorman 2005c; Inoue 1994, 516-517). Media personalities, such as the influential and prolific journalist Ōya Sōichi, also played an important role in shaping the negative image of new religions (Dorman 2005c) and in creating specific tropes with which to designate these groups.

Such attention on the supposedly rapid growth in the number of religious organisations or in religious practices has been a recurrent theme in media portrayals of new religions. In the late 1970s, for example, the media began to draw attention to a "return to religion" (shükyō kaigi) and religious boom (shükyō bümu ${ }^{19}$, Inoue 1992; Ishii 2008; Shimazono 1992b). ${ }^{20}$ The basis for asserting a supposed revival of religious practices and beliefs 
were two surveys, Nihonjin no Kokuminsei (The Japanese National Character) conducted by the Institute of Statistical Mathematics (Tōkei Sūri Kenkyūjo), a national research institute, and Nihonjin no Ishiki (Japanese Consciousness), a public opinion poll conducted by NHK, Japan's national broadcasting corporation, both showing a supposed increase since 1973 in respondents claiming to have some sort of religious beliefs and to be interested in religion (Inoue 1992, 208; NHK Hōsō Yoron Chōsajo ed. 1979; Shimazono 2001a,175-176). As discussed in Reader (1990), academic discussions about religion in modern society affected the interpretation of this survey data. A shift occurred in the mid-1970s and corresponded to a new approach to theories of secularisation, in which religion started to be seeing not as opposed to, but compatible with, modern society. At the same time, the media started showing an interest in religion-related topics and practices. Between 1976 and 1977, the Mainichi newspaper published a series of five volumes $^{21}$ investigating the state of religion in Japan (Reader 1990, 62-63) that included a portrayal of a vibrant religious life. The series attracted a remarkable amount of interest, and other news and accounts about religious practices started to appear more frequently in mass media. Stories on mysticism and occult-related phenomena were featured in broadcasts and printed media (Haga and Kisala 1995, 237). Popular magazines specialising in the occult and supernatural phenomena (and in the sale of related goods), such as $M \bar{u}$ and My Birthday, were established in the late 1970s, and translations of books associated with the New Age in the American context or with related topics, such as Nostradamus's prophecies, ${ }^{22}$ were published. Concurrently, popular movies, such as Genma Taisen (1983) and Akira (1988) popularised science fiction and apocalyptic themes (Haga and Kisala 1995, 238), and variety shows with religious content appeared on prime time TV (Ishii 2008, 19).

Scholars have expressed doubts regarding a quantifiable religious "boom" in the period (Inoue 1992; Ishii 2008), instead directing attention to the boom as a media-driven phenomenon, such as, for instance, an increase in TV programmes from the 1970s devoted to topics such as supernatural powers, prophecies, UFOs, telepathy and so on (Ishii 2008). According to Inoue, if a boom existed, it was more related to the increase of information about religion (Inoue 1992, 338-348) than an increase in interest in something specifically religious or spiritual. The role played by the media in shaping definitions of religious practices in this period, "encouraging consumption of occult information as a form of entertainment" (Haga and Kisala 1995, 238), created an interesting overlap between the spheres of media, religion and marketing. An interesting example is provided by the use of the term seishin sekai (spiritual world), a term used to indicate an amorphous group of religious practices and teachings organised around loose networks or small groups. ${ }^{23}$ It is outside the scope of this research to attribute the correct genealogy to the term, but it appears that it started being used around the same time by the media, practitioners, bookstores and new religions. 
Publications loosely addressing the variety of topics related to the "spiritual world" (from channelling to meditation, yoga, mysticism and so on) started appearing in the 1970s. Events on the seishin sekai were also organised in bookstores and department stores. For example, in June 1978, the bookstore Kinokuniya in Tokyo organised an event on Indo-Neparru Seishin Sekai no Hon ("Books About the Indo-Nepalese Spiritual World"). In the same year in December, the bookstore Prasad hosted an event on Seishin Sekai no Hon-Best 800 ("Best 800 Books on the Spiritual World"). In 1981, Kinokuniya opened a fair titled Seishin Sekai no Hon ("Spiritual World Books") and in the 1980s, a seishin sekai corner started appearing in different bookstores (Fig. 1.1). Articles related to the spiritual world appeared in newspapers, ${ }^{24}$ while publications by new religions also started to use the term. In 1977, for example, Za Meditēshon ("The Meditation"), a new quarterly magazine published by Hirakawa, a publisher connected to the new religion Agonshū published a ranking of the top 100 books on the "spiritual world" (Shimazono 1996, 168). Furthermore, volume seven of Agonshū's magazine Meisō Meditation in 1982 was devoted to the theme of the "spiritual world", and the same group used the term seishin sekai in several publications and events from the late 1970s. ${ }^{25}$ Therefore, the term offers an interesting example of how marketing, new religions and

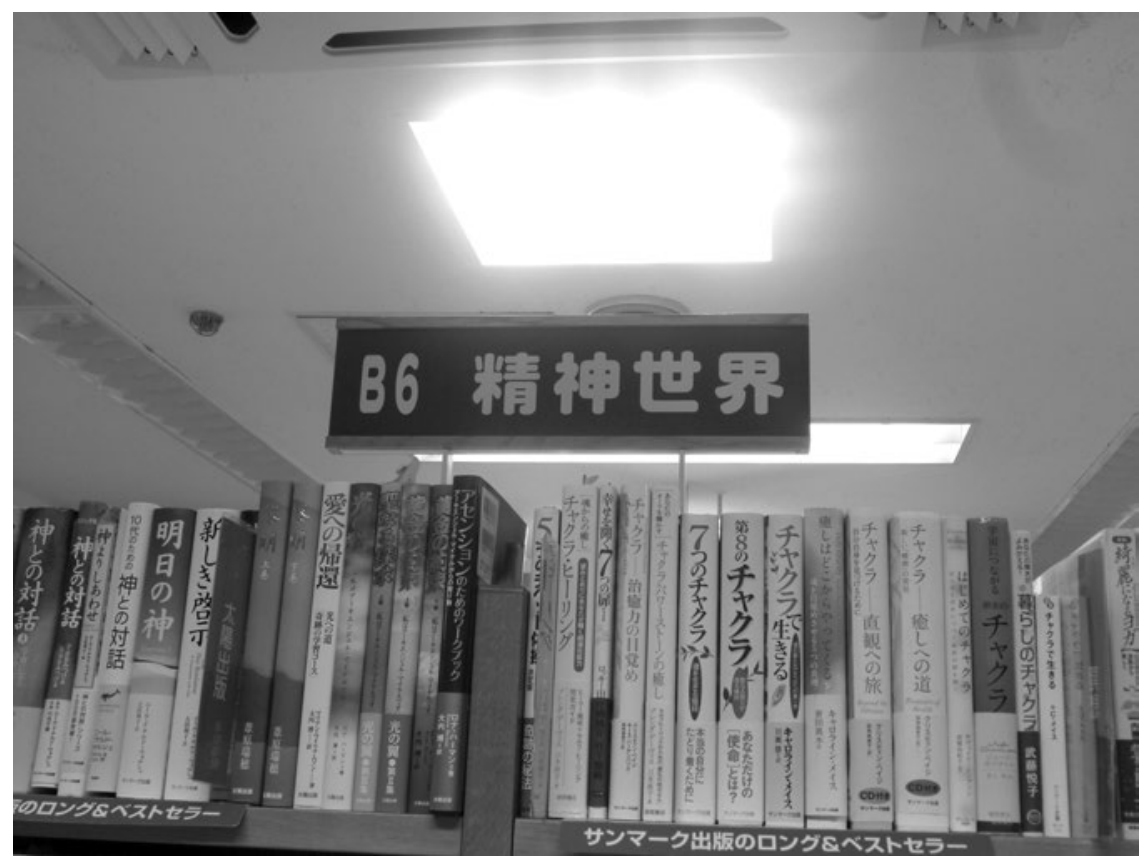

Fig. 1.1 Seishin sekai (Spiritual world) section in a major bookstore in Tokyo. Photo by Erica Baffelli. 


\section{Media and New Religions in Japan}

media, often considered entirely separate spheres, used similar references and imaginary, and equally participated in the construction of a supposed "religion boom" in Japan in the 1970s and 1980s.

These are only few examples of a wider pattern of interconnectedness between new religions and media in Japan and in particular the role played by the media in shaping the image of new religions since the Meiji period. As these examples demonstrate, the ways in which media and new religions interact are neither stable nor predictable, while larger historical and political contexts have influenced media attitudes toward new religions. Furthermore, although media reporting on new religions has tended to be critical, there have been instances where new religions attracted media curiosity and even, although less commonly, resulted in positive portrayals. This dualism in media approaches continued during the 1980s and early 1990s, when, as mentioned above, topics related to spiritual and religious practices often appeared in newspapers, magazines and entertainment TV shows, and spectacular events and large advertising campaigns sponsored by new religions attracted media curiosity and controversies (see Chapters Two, Three and Four in this volume).

\section{THE AUM AFFAIR AS A “TURNING POINT”}

The relationship between the media and new religions that I have briefly outlined above changed on March 20, 1995, when members of Aum Shinrikyō perpetrated the nerve gas attack on the Tokyo metropolitan subway. Responsibility for this and other atrocious crimes was attributed to Aum's leader Asahara Shōkō's (born Matsumoto Chizuo, 1955-) influence upon his followers. Tensions between the group and society had already appeared in previous years, and legal groups in opposition to Aum were established already in the late 1980s, such as the Aum Shinrikyō Victims' Society (Oumu Shinrikyo Higaisha no kai) that started in 1989. Others appeared immediately after the sarin attack, such as the Subway Sarin Incident Victims' Association (Chikatetsu Sarin Jiken Higaisha no Kai) and the Japan Society for Cult Prevention and Recovery (Nihon Datsukaruto Kyōkai). The Aum Affair (Oumu jiken), as it was referred to in the media, is considered an important turning point in the relationship between religion and society in Japan (Baffelli and Reader 2012; Kisala and Mullins 2001) and it strongly affected how religion is perceived there nowadays. ${ }^{26}$

Following the attack, journalists, lawyers and anti-cult activists became the main public voices claiming knowledge about Aum (Wilkinson 2009, $120)$, and they called for a greater control on new religions, now labelled "cults" and accused of brainwashing their members. ${ }^{27}$ Several texts published by American anti-cult activists were translated into Japanese. ${ }^{28}$ Furthermore, many representatives of American anti-cult movements were invited to Japan and anti-cult activists such as Steve Hassan and Asami 
Tadao frequently appeared on television (Wilkinson (2009, 129). Anti-cult journalists, such as Egawa Shōko, who was very critical of Aum before 1995 and published extensively against the group (Egawa 1991a; Egawa 2000), achieved greater credibility and visibility. Before 1995, being a small-scale group, Aum Shinrikyō had not been extensively studied. This caused a lot of criticism toward Japanese scholars, who were accused of not having recognised the potential public threat and even of having been supportive of Aum $^{29}$ (Baffelli and Reader 2012; Dorman 2012b; Reader 2000b; Tsukada 2011; Watanabe 2001). As a consequence, the media became the primary source of information about the group, as explained by Hardacre:

Besides the media coverage that reported Aum's various scrapes with the law since 1989 and mostly since the subway attack, Aum's own publications, a couple of 'instant books' rushed out after the police investigation began, and a single book by investigate reporter Egawa Shōko, no literature of volume or substance on Aum had been available. [...] In the absence of academic research, scholars, no less than the general public, were heavily dependent upon media representation for their understanding of this religion and the nerve gas attack.

(Hardacre 2007, 173)

At the same time, the media were accused of letting the group and its leader's imposing personality use and manipulate them. Indeed, the group used the media not only for promoting its image and political activities, but also to confront its critics and to counter its negative image (Dorman and Reader 2007; Hardacre 2007; Reader 2000a). Yet, in the period immediately after the sarin gas attack and before Asahara's arrest in May 1995, several television debates occurred between anti-Aum activists (such as Egawa Shōko, Arita Yoshifu, Takimoto Tarō) and the group's representatives, such as Murai Hideo, Aoyama Yoshinobu and Jōyū Fumihiro (Gardner 2001). ${ }^{30}$ For several months after the attack, until the end of 1995, Aum Shinrikyōrelated issues continued to receive extensive coverage in newspapers and on TV news programmes. ${ }^{31}$ In 1996, television broadcasting on new religions decreased and between 1996 and 1999, news concerning these groups was very limited. At the same time, new religions decreased their big public events (in the same cases, the media were no longer invited to attend these events) and reduced their massive advertising campaigns in order to avoid harsh criticism. Suddenly, these religious groups seemed to disappear from view.

The sarin gas attack therefore forced both the media and religious groups to renegotiate and change their relationship. The media assumed for a brief period both the role of society watchdog, in a sense reasserting the role they had assumed during the Meiji period, as mentioned above, willing to denounce and publicly expose potentially "dangerous" groups, but they also took on an educational role (Dorman 2012a, 239) in order to provide 


\section{Media and New Religions in Japan}

information on Aum, due to the lack of knowledge and information available about the group.

On the other side, new religions reacted by condemning Aum's actions, distancing themselves from it (Kisala 2001a, 195), and re-evaluating their image strategies. For these reasons, it is important to understand that the media strategies of new religions in Japan must be examined in terms of the period before and the period after the events of 1995 .

Several works have addressed the relationship between the media and Aum Shinrikyō and about how media representations of religion in Japan changed after the sarin gas attack (Dorman 2001; 2012a; Dorman and Reader 2007; Gardner 2001; Hardacre 2007; Inoue 2012; Reader 2000a; Watanabe 2005). As mentioned earlier, the relationship between religion and media in Japan in the 1980s and in particular the 1990s cannot be understood without reference to the traumatic events of 1995. After the Aum Affair, religious organisations in Japan had to face open criticism and still-lingering negative images of religion in society. As other studies have discussed (Baffelli and Reader 2012; Chilson 2004; Dorman 2012a; Gagné 2014; McLaughlin 2012), the consequences of the Aum Affair involved not only new religions, but also more traditional religious organisations with no evident link to Aum. For the groups discussed in this book (Agonshū, Kōfuku no Kagaku and Hikari no Wa), the situation was more complicated, due to the fact that they were, as discussed in the Introduction, more or less directly a target of criticism and were associated in the public mind with Aum. In the case of Kōfuku no Kagaku, the group had been seen as Aum's rival. Despite Kōfuku's open criticism towards Aum (the group also organised several anti-Aum demonstrations and regularly criticised Aum in its publications), the two groups were perceived as similar by the general public due to the fact that they both had a young leader and young, well-educated membership and a similar interest in public visibility, showed, for example, by their intense use of the media and frequent appearances on television.

After numerous Aum members were arrested and extended and very detailed reports about Aum started to appear in the media, Agonshū became a focus of attention because Asahara had been affiliated with the group before leaving to found Aum. Although Agonshū immediately distanced itself from Aum and tried to downplay the relevance and length of Asahara's membership, the media claimed that Kiriyama's teaching had influenced Aum's doctrines, and this shed a negative light on the group. The book published by Kiriyama Seiyū (Kiriyama 1995), Agonshū's leader, to explain the differences between his group and Aum clearly illustrates the pressure placed by the media on the group after the attack. Finally, Hikari no Wa is one of the two splinter groups created by ex-Aum members, and its leader, Jōyū Fumihiro, maintained a highly public profile before and after 1995 .

Therefore, the analysis of religion and media in the 1980s and 1990s in Japan offers an important angle on the discussion of how traumatic events could impact image shaping and member-leader relationships. It also shows 
that evaluations of the impact of violence and trauma should not be limited to the analysis of the group that committed violence or to the victims, but also extended to consider the wider effects on society. Moreover, it demonstrates that traumatic events could suddenly shift the attitude of the media toward religion. In the Japanese case, for example, after 1995, new religions were no longer viewed mainly as unusual groups with extravagant leaders who could create audiences, but they became potentially dangerous groups. Media institutions, which received severe criticism after the Aum Affair for having provided Asahara, on several occasions, with a public and wide-reaching stage and visibility by inviting him onto talk shows, for example, reacted to criticism by becoming very suspicious of any new religions that could be potentially seen as "similar to Aum" (Baffelli and Reader 2012; Dorman 2005b). ${ }^{32}$ Otherwise, they avoided reporting about new religions' activities. This applied not just to new religions, but also to more established religious organisations (Hardacre 2003). Finally, the sarin gas attack happened while a major publisher, Kōdansha, was involved in a long legal suit with another new religion, Kōfuku no Kagaku. The so-called Kōdansha Friday Affair (Kōdansha Furaidē Jiken), see Chapter Four in this volume) also impacted the negative media image of new religions, and it reinforced the image of new religions as potentially belligerent and prone to aggressive responses to criticism.

The above-mentioned documentary by Mori Tatsuya is again an emblematic example of the fact that, after the Aum Affair, when representations of new religions in the media tended to be negative, divergent or more nuanced voices were not accepted. Mori Tatsuya was the only non-member allowed inside the group's facilities to film members' daily activities after the sarin gas attack and the arrest of Asahara and other senior members. As recounted by the director himself (Mori 2000), he was first commissioned to produce a TV documentary on Aum, but when he obtained permission from the group, he decided to film their daily activities and to present a documentary without overall commentary. His employer didn't support this new idea and fired him, so Mori was forced to interrupt his filming and to opt for a self-produced documentary. When $A$ was finally completed and showed at movie theatres in Japan, the director expected to create a debate regarding his different approach in presenting Aum members, who were showed in their quotidian routines and interactions with neighbours, and presented them as people who had divergent opinions on the crimes committed by other members, showed individual personalities, and who were far from being "brainwashed". Mori's documentary also showed that the media and police exasperated Aum members, creating in the viewers the impression of watching the unfolding of events from members' points of view (although in reality, this view was still mediated by Mori's gaze into the camera and his editing of the movie). Viewers are also confronted with the limits of supposedly detached media reportage, when Mori is asked to intervene and provide a video he filmed during a confrontation between members and 
The Public Security Intelligence Agency (kōan chōsachō) officers, in order to help an Aum member to be released from gaol. Mori himself, at this point, became part of his documentary, thereby creating an overlap between the media (himself) and the religion (the group): it is then unclear who is filming whom and whose experiences are narrated in the documentary. The unfolding of Mori's $A$ reveals the different layers involved in the complex relationship between media and religion in 1980-1990s Japan. These layers include the need for the group to tell its truth-and the fact that only the media could help it to have a public face; the search for the "truth" by Japanese media after the traumatic event, which resulted in obsessive reporting about and scrutiny of Aum and its members; the need to create an uncompromising distinction between "evil" and "good"-which resulted in Aum's members not being accepted as "ordinary", but only as "deviant" and problematic, in order that the evil should be something far and strange, not familiar and "banal"; the morbid attention paid by the media to Aum's members-with the extreme example of Murai Hideo, one of Aum's senior representative, being stabbed to death in front of journalists and TV crews, which did not stop filming the event (Gardner 2001); the risk for the media of being trapped in an ethical dilemma when dealing with Aum, as exemplified by Mori's experience; and, finally, the media and public rejection of any alternative construing of the event. Indeed, Mori's documentary was not received with criticism, but was completely ignored (Gardner 2001).

\section{BEYOND CRITICISM}

Media reports on new religions tend to be unsympathetic, but it would be erroneous to claim that all representations of new religions were negative, especially in the pre-1995 era (Dorman and Reader 2007). Indeed, Aum itself received, as mentioned above, some positive representations in the media. On September 28, 1991, for example, Asahara and other Aum members were invited as panellists, together with members of Kōfuku no Kagaku, on a four-hour-long, live programme called "Live TV Until Morning" (Asa Made Nama Terebi) on the Asahi network to discuss the topic of Shükyō to wakamono ("Religion and Young People"). In the following days, several positive comments about the group's performance during the debate and its members' knowledge of Buddhism were circulated by scholars and media personalities, such as Beat Takeshi ${ }^{33}$ (Watanabe 1997, 37-38).

The media are not only an important source of information on new religions, but see emerging groups and their leaders as providing a source of interesting stories. Newspapers and magazines can increase circulation via reporting rumours and scandals involving leaders and members. Similarly, television programmes have attracted viewers' attention by presenting unusual personalities and practices (not only Aum and Kōfuku no Kagaku, but representatives of other groups such as World Mate ${ }^{34}$ and Hō no Hana 
Sanpōgyō $\bar{c}^{35}$ appeared on talk shows). In his study on postwar new religions, Dorman also showed how media reports about a group called Tenshō Kōtai Jingūkyō, ${ }^{36}$ although often critical, were not entirely negative and that journalists had a more positive attitude after they interviewed Kitamura Sayo, the group's leader, and her followers (Dorman 2012a, 191). Similarly, Mori Tatsuya commented that his opinion about Aum, which he previously had considered a dangerous group, changed after he met the group members and started filming his documentary. ${ }^{37}$

Another often-overlooked element that has an impact on media reporting on new religious is related to the fact that religious groups, including new religions, could become important sources of revenue for newspapers through advertising. ${ }^{38}$ In general, new religions' events and publications are promoted not only in in-house publications, but also in external media, posters at train stations, billboards, leaflets and so on. It was in particular from the 1970s that some new religions started investing in large advertising campaigns in magazines and, less frequently, on television. ${ }^{39}$ In 1971, for example, the group Reiyūkai, a lay Buddhist organisation founded in 1925 by Kakutarō Kubo (1892-1944) and Kimi Kotani (1901-1971) (Hardacre 1984) launched a campaign entitled, "Inner Trip-ningen no kokoro ni kaerō" ("Inner Trip: Returning to People's Hearts"), which represents one of the first examples of mass media used for proselytism advertising. The advertisements were published in large format in newspapers and magazines and aimed to attract a young audience and to change the image of religion from something looking old and outdated (toshiyorikusai, Iwasa 1993, 131) to something modern and up to date. The following year, the group launched the monthly magazine Inna Torippu (Inner Trip), and its first issue sold four hundred thousand copies (Iwasa 1993, 132). Around the same period, on August 18, 1973, Tenrikyō started an advertisement campaign with the slogan "Ningen onaji kyōdai" ("People are all Brothers and Sisters"), which occuppied a full page in the morning edition of forty-two newspapers throughout the country. In the late 1980s and 1990s, Agonshū was one of the most media-savvy groups and sponsored large advertisement campaigns to promote the leader's publications or its events, such as the annual Hoshi Matsuri (Star Festival, also Stars and Fire Rites Festival). ${ }^{40}$ As will be discussed in Chapter Three, Agonshū also employed advertising agencies to promote its image, a strategy used in the 1990s also by Kōfuku no Kagaku for its large promotional campaigns (see Chapter Four in this volume). Although more research is needed on the economic aspects of the relationship between the media and new religions, it is possible to speculate that economic issues may also affect reporting on new religions, as mass media institutions, dependent on advertising revenue, may well have been reluctant to attack groups that were important sources of income.

The entrepreneurial skills of some new religions have also been recognised by media and communication analysts and these have led to some, although infrequent, positive representations of these groups. For example, in 1993, Senden kaigi, a publication specialising in marketing communications, published a series by Iwasa Yoshiya, a marketing producer, titled 
Shūkyō ni manabu maketing katsudō ("Learning Marketing Activities from Religion"). In the second part of the series (titled Kyōdan no kōkoku puromōshon, "Religious groups' promotion through advertising”, 1993) strategies implemented by several new religions (such as Kōfuku no Kagaku, Aum Shinrikyō, Agonshū, Byakkō Shinkō Kai, Seichō no Ie and Tenrikyō) to promote their images are analysed from the point of view of three marketing ideas, concept, activism and performance, in order to demonstrate how the appropriate balance between these elements has resulted in these groups' success in the religious marketplace. The same magazine published in 1994 a series titled Shūkyō no māketingu chikara ("The Marketing Power of Religion", 1994), in which an article by Maeno Kazuhisa, a professor of information studies at Gunma University, defined "religion" as an "information society" (jōhō sangyō, Maeno 1994, 78). ${ }^{41}$

Therefore the media, while often hostile, has been dualistic in its representations of new religions. What is undeniable is that the media in Japan has had a central role in defining these groups and has been seen as a trustworthy authority defining how we should think about religion and the religious groups that we could accept in society and those that should be labelled as "dangerous". Recent publications (Fujiyama 2011a, 2011b; McLaughlin 2016) have discussed changes in media discourse about religion following the Great East Japan Earthquake disasters in March 2011. These studies make similar observations about how the recent traumas have not resulted in a particular increase of media reporting about religion, but, compared to the post-1995 Great Hanshin/Awaji earthquake ${ }^{42}$ and post-Aum Affair context, media narratives about religion have been more positive since 2011. As McLaughlin noted, however, positive representations focus on interdenominational activities promoted by some organisations that are supported by specific "information curators", while "religious actors who do not fit a sanitized discourse deemed acceptable for public consumption" (McLaughlin 2016, 39) are still excluded. New religions have been (and still are) often represented as "problematic", so they have to develop strong media strategies to present a different perspective and publicise their self-image. This leads to the discussion on how new religions use media.

\section{NEW RELIGIONS' USE OF MEDIA: A BRIEF OVERVIEW}

Media forms have been important tools for new religions that use publishing and visual technologies for training, communicating with members, presenting their messages, reinforcing or protecting the image of the leader and potentially attracting converts. Media forms are also employed to affirm authority and legitimacy, for instance, to prove that new religions have a solid textual basis and should be considered legitimate religious organisations. Furthermore, media mastery displays images of leaders as multi-talented individuals, up to date and able to use technologies: for example, Sōka 
Gakkai has published collections of the group leader, Ikeda Daisaku's, photographs, and Ōkawa Ryūhō, leader of Kōfuku no Kagaku, recently promoted his collaboration with his son in writing the original script of one of the animated movies produced by the group (Tsukada 2010). ${ }^{43}$

The intensive use of media by new religions was highlighted in both academic studies and journalistic reports on these groups that have at times been labelled as "media religions" (media shūkyō, Inamasu 1992). However, it is important to clarify that these groups are not completely mediated (i.e. existing only in the media or having all their practices and activities supported by media), but that they use the media to support some of their practices and activities. The chapters in this book will discuss a number of examples in which media forms have had a relevant role in shaping religious practices or leader-member relationships, but I should emphasise also that new religions continue to operate primarily through their local and national centres, which are promoted online and via media means. Furthermore, media usage was not the only reason for the success of new religions. Earlier studies, such as McFarland $(1967,92),{ }^{44}$ emphasised the role of media in the development of new religions, but they did this as a way of minimising their relevance and implying that they were ephemeral, media-driven phenomena with an emphasis on proselytism and propaganda. This portrayal, as we will see, is simplistic and does not acknowledge how the media strategies implemented by some groups are highly sophisticated (indeed, other religious organisations, such as the Sōtō Zen Buddhist sect, showed an interested in new religions' image strategies and admitted that they should follow their example (Reader 1983)). Consumer society from the early twentieth century "provided religious organisations [...] with new marketing opportunities" (Stalker 2008, 110) and media technologies, from photography to satellite broadcasting and finally to the Internet, offered new platforms for disseminating teaching, explaining doctrines and branding leaders' images. As far as organisational aspects are concerned, numerous new religions have teams specialising in public relations or in media planning. ${ }^{45}$ Some groups, as will be discussed later, also employ advertising agencies or web communication experts. Numerous groups, moreover, have their own publishing houses. They also distribute their books not just via their own religious centres but through general bookshops, which often have special sections for groups with large publications, such as Sōka Gakkai, Seichō no Ie and Kōfuku no Kagaku (Fig. 1.2).

It is beyond the scope of this book to provide a comprehensive account of the media used by new religions since the late nineteenth century. However, I will provide a brief overview, in chronological order, from the press to the Internet, and a few examples to highlight some pioneering entrepreneurial initiatives implemented by new religions and to emphasise the variety of media strategies that have been developed.

One of the forerunner groups in implementing a savvy use of media for enhancing the group's public image was Oomoto, a group founded in 1892 


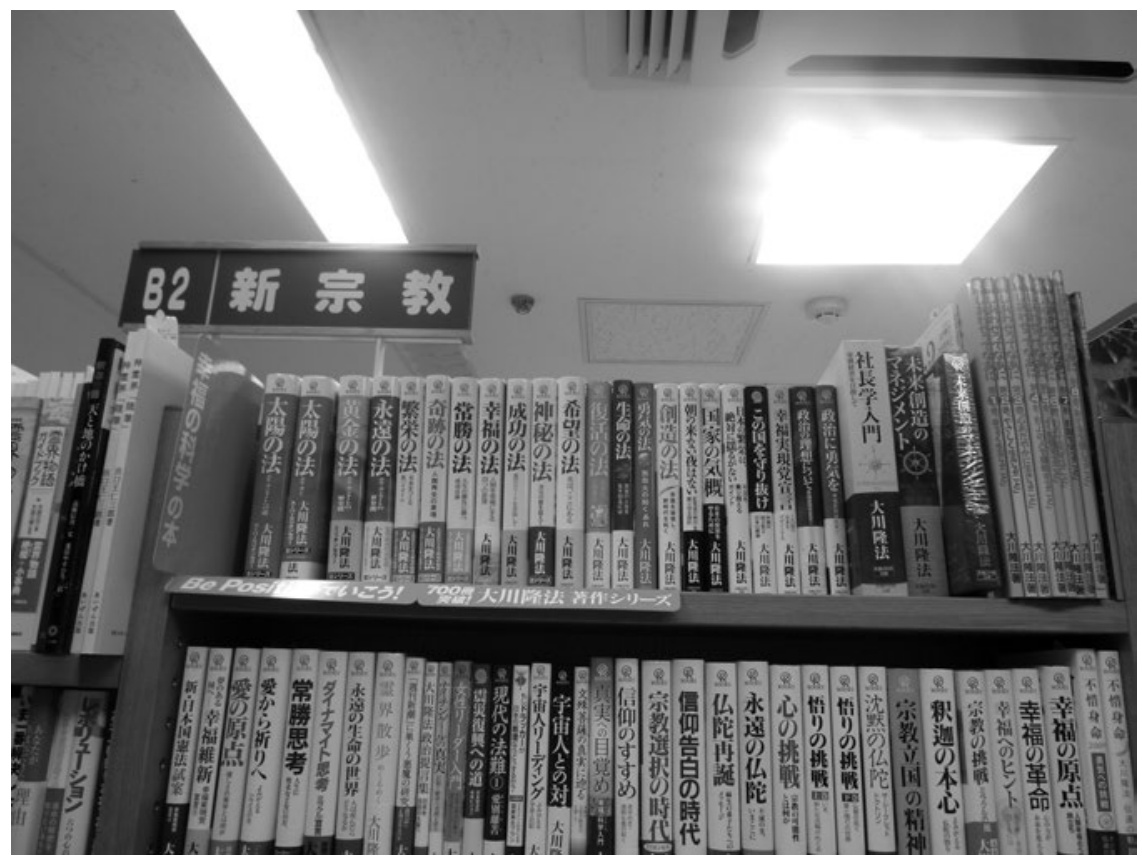

Fig. 1.2 "Kōfuku no Kagaku" section in a major bookstore in Tokyo. Photo by Erica Baffelli.

by Deguchi Nao (1836-1918). It was under the co-founder Deguchi Ōnisaburō (1871-1948) that the group's media strategies were implemented. In 1908, the group published its first magazine, called Honkyo kōsh $\bar{u}$, and by 1929 , it owned thirteen magazines. In 1920, the group bought an Osaka newspaper, the Taishō Nichinichi Shinbun, published a magazine in the Esperanto language called Oomoto in 1925 and opened its own publishing house in 1931. Deguchi Ōnisaburō, in particular, extensively employed print media and recognised the power of visual images. Oomoto also implemented what we would now define as "media mix" (in Japanese media mikkusu), a combination of different media technologies and advertising strategies to promote the group and target different audiences: magazines, journals, photograph albums and visual media, in particular, film. ${ }^{46}$ Movies could be used to attract larger audiences and reach viewers outside the sphere of Oomoto's members, a strategy that, as will be seen later, was implemented by other groups by using public events and spectacular rituals (such as Agonshū's Hoshi Matsuri discussed in Chapter 3 in this volume). Furthermore, movies were used by Oomoto to enhance the leader's charismatic aura and create visual associations between the leader and various figures in the Japanese religious pantheon. In the film Show no no shichijifukujin ("The Seven Lucky Gods of the Showa Period"), for example, Ōnisaburō dressed in costumes 
representing each of the Seven Lucky Gods (shichijifukujin, Stalker 2008, 133-137) and embodied the deities. It is clear that Oomoto's legacy is important for new religions' media strategies, especially for the importance placed on visual media. For example, in the 1990s, Ōkawa Ryūhō, leader of Kōfuku no Kagaku, dressed up in a similar fashion, as deities he was supposedly reincarnating during ceremonies. In addition, other groups developed different strategies; Oomoto was not a unique example of religious groups experimenting with media language and imagery.

Among the media, the press played a central role in the development of new religions and in their communication strategies. Large publications were used, not exclusively by new religions and not uniquely in Japan, to reach out to a wider public, but also to convey the idea of a valid religion with a large textual base, and to enhance their leaders' charisma-Seichō no Ie, Kōfuku no Kagaku, but also Scientology (to cite an example from outside Japan) are just a few examples of movements that operate in this way. For many new religions, the publication of leaders' teachings, diaries and doctrines has played an important role in the process of institutionalisation. The oral messages of the kyōso (founders) are often rewritten in a later period of development of the group as its teachings are systematised into a more fixed doctrine. They are therefore transformed into "sacred texts" (Berthon and Kashio 2000, 72) that are used to reclaim the legitimacy of the group as part of a coherent and valid religious tradition and also as training materials for members. ${ }^{47}$ Earlier groups, such as Tenrikyō and Oomoto, are examples of this process.

Printed media are still nowadays central for new religions in Japan; in most cases, they still are the most used media and an important source of revenues. New publications are promoted with massive advertising campaigns and public events and leaders' publications often appear in the bestsellers rankings. One of the first groups to start advertising its publications during the 1940s was Seichō no Ie, a group founded in 1930 and registered under the Religious Juridical Persons Law (Shūkyō Hōjin Hō) in 1952 (Staemmler 2011, 144). The group has been named by the media as "the publisher religion" (shuppan shükyō) ${ }^{48}$ and "the advertising religion" (kōkoku shūkyō, Iwasa 1993, 130) to point out the large amount of publications it has promoted. The founder, Taniguchi Masaharu, a former member of Oomoto, believed in the importance of the press, radio and television in the diffusion of his teachings (Enomoto 2006; Ishii 1994, 331; Iwasa 1994), and the first magazine published by the group, Seicho no Ie, was launched in 1930 (Inoue 2012, 124). Printed media used by new religions include newspapers, such as the above-mentioned Taishō Nichinichi Shinbun owned by Oomoto, and the Seikyō Shinbun, founded in 1951 by Sōka Gakkai and currently, with a circulation of 5.5 million copies, representing the third-largest circulation in Japan for newspapers (McLaughlin 2009, 143). Other publications, such as magazines, are diversified according to the audience (members, non-members, children, young members and so on), of which earlier 
examples are Michi no Tomo ("Friend of the Way"), a magazine launched in 1891 by Tenrikyō and Tenri jiho ("Tenri Chronicle"), launched in 1930 by the same group (Inoue 2012, 124); both are published by Tenrikyō's publishing house, Dōyūsha, established in 1891. Kōfuku no Kagaku, for example, currently publishes six magazines in Japanese: Kōfuku no Kagaku Happy Science, established in 1987 and recently supplemented by the small booklet What's Kōfuku no Kagaku; The Liberty, a monthly magazine on social, and political issues established in 1995; Za dendo ("The Mission"), a bimonthly publication for members and Herumesu Enzerusu ("Hermes Angels"), for children, both founded in 1996; Are you happy? a monthly women's magazine started in 2004; and Young Buddha, a magazine for young followers published from 2005. At the moment, the group publishes only one magazine in English, Happy Science Monthly. ${ }^{49}$ In general, the topics covered in magazines include articles on doctrinal aspects-often with practical examples of application to everyday life-excerpts from leaders' publications, information and reports on activities, essays about lifestyle and commentary on socio-political events. Several pages are often devoted to interviews or testimonies by members about their experiences as well as to advertisements of books or other items. Sometimes, advertisements of members' businesses or services are also included, providing a source of income for the group. ${ }^{50}$

Manga ${ }^{51}$ or comics, have also been used by new religions, especially to reach a younger readership. Most of the manga produced by new religions have a didactic orientation and this can make them pedantic and even "potentially boring" (Thomas 2012, 71). ${ }^{52}$ However, they deserve attention as part of the communication strategies used by groups and because they reveal groups' attempts to reach different audience segments and to "experiment" with different media. Manga have been used by several new religions to spread their message or, in some cases, to attack their critics (as the manga discussed in Chapter Four of this volume will illustrate). Differently from manga published by commercial publishers, religious manga are not initially published in episodic form in weekly or monthly magazines, but usually they immediately appear as paperbacks. Some publications (such as, for example, Kōfuku no Kagaku's manga) can be purchased at larger bookstores in Japan. Authors are often members of the group (for example, Aum's manga were created by members of Aum's Manga and Anime Team, Fig. 1.3), but sometimes the religious organisations may employ professional mangaka (manga artists) or animation studios to create and distribute their products, in order to potentially increase visibility and have a wider distribution of works.

Some of the earlier examples of manga published by new religions focused on the biography of the leader to show his/her importance as a central element for the group, such as, for example, The Founder of Konko Religion, ${ }^{53}$ published by Konkōkyō in 1966 (Ishii 1994, 326), and the longer series, dedicated to the founder Makiguchi Tsunesaburō and his successor, Toda Jōsei, in Sōka Gakkai: Makiguchi Sensei ("The Teacher Makiguchi”, in thirteen 


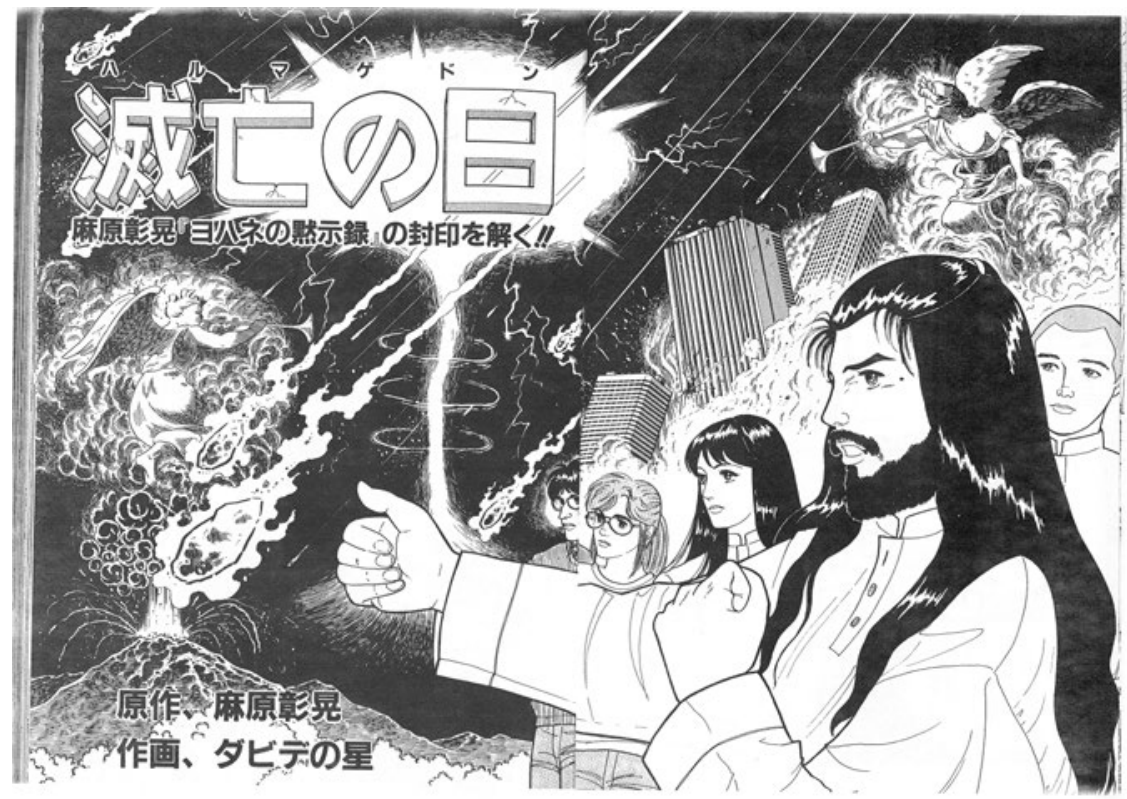

Fig. 1.3 The manga Metsubō no Hi ("Doomsday") published by Aum Shinrikyō.

volumes, 1972-79) and Komikku Kyojin Toda Jōsei ("The Great Men Comic"-Toda Jōsei, in five volumes, 1984). Usually, the life of the leader is narrated through major events in his/her life and particular attention is given to the first spirit possession or call by a kami. Graphic techniques are sometimes used to visually illustrate the leader's change from a "common person" to a divine being. For example, in the manga series Kyōso monogatari ("The Story of Our Founder") published by Tenrikyō in 1987-1988 (and reprinted in 2008), Nakayama Miki's face disappears after she "becomes" a kami (Ishii 1994, 24). Other publications include works focusing on doctrinal explanations that can be used for proselytism or for members' training and education. For example, in Tenrikyō's Ritoru magajin ("Little Magazine"), the teachings are applied to daily life situations such as school exams or relationships with classmates. Other works are used to provide an illustrated edition of already published books and their style recalls that of information manga (jōho manga, MacWilliams 2012, 606), that is, comics with an educational purpose. In these manga, large sections are often devoted to written text quoted from the original work and images tend to be static. For example, the manga versions of the first three volumes of Kōfuku no Kagaku's Laws Series, Taiyo no hō (illustrated by Hashimoto Kazunori, Ōkawa and Hashimoto 1996-2000), Ōgon no hō (illustrated by Hashimoto Kazunori, Ōkawa and Hashimoto 2003a; 2003b; 2004) and Eien no hō (illustrated by Hashimoto 
Kazunori, Ōkawa and Hashimoto 2006) are characterised by plain and simple images in well-defined and closed cells, the predominance of written text that faithfully follows the content of the original text, didactic explanations of each character and very little narrative development.

Some of these books and manga have been made into animated films. ${ }^{54}$ For example, Kōfuku no Kagaku between 1994 and 2012 released several films based on Ōkawa's writings, most of them as animated movies: Herumesu ai wa kaze no gotoku ("Hermes, love as the wind", 1997), Taiyo no hō ("The Laws of the Sun", 2000), Ōgon no hō ("The Golden Laws", 2003), Eien no hō ("The Laws of Eternity", 2006), Buddha Saitan ("The Rebirth of Buddha", 2009) and Shinpi no ho ("The Mystical Laws", 2012). ${ }^{55}$ The movies were widely advertised and shown at mainstream cinemas throughout the country, and many were produced by the well-known Japanese corporation Toei Animation (Tōei Animēshon Kabushikigaisha). Kōfuku no Kagaku's anime are not simply the adaptation of books or manga into animated movies, but they are part of a wider multimedia strategy including advertising campaigns, ad hoc manga (created when the film is released), sophisticated websites (devoted to the film), posters, figurines, collectable and games (sold or distributed at the launch of the movie). The visual media allow the possibility to iconographically represent all the deities, historical characters and events narrated in the leader's books and to integrate them in a fantasy story where the main characters are usually a young couple (male and female) who are, as the audience will discover at the end, members of Kōfuku no Kagaku. The stories develop in different adventures, but the conclusion is always the discovery of the "light from Japan", the spirit of El Cantāre (the group's supreme deity, who is reincarnated in the leader). For example, in the anime Ögon no hō ("The Golden Laws", 2003), the story is set in the future, in 2403, where Satoru, a student of the U.H.S. (University of Happiness Science), located in a city called New Atlantis, finds a book called The Golden Laws in the school library. Shortly after, a time traveller called Alisa visits him from the thirtieth century. The two decide to start a time travel together to explore the twenty-first century, but a malfunction of the time machine will sent them through different historical periods and geographical areas (Ancient Greece, India, China, Palestine) where they will meet important historical and religious figures (such as Hermes, Moses, Jesus, Siddhartha and so on). Their travels become a spiritual journey through which they learn different expressions of "love" and "courage", thanks to the help and teaching provided by their guides. The anime was launched with an advertising campaign in newspapers and on television, and with the distribution of flyers (Fig. 1.4) and posters. Toei Animation, which produced the movie, also created a sophisticated website $^{56}$ in English and Japanese with trailers of the movie, posters and press reviews. The website also included an interactive game allowing the visitors to "travel" through different historical periods and also a test to discover one's previous lives. 


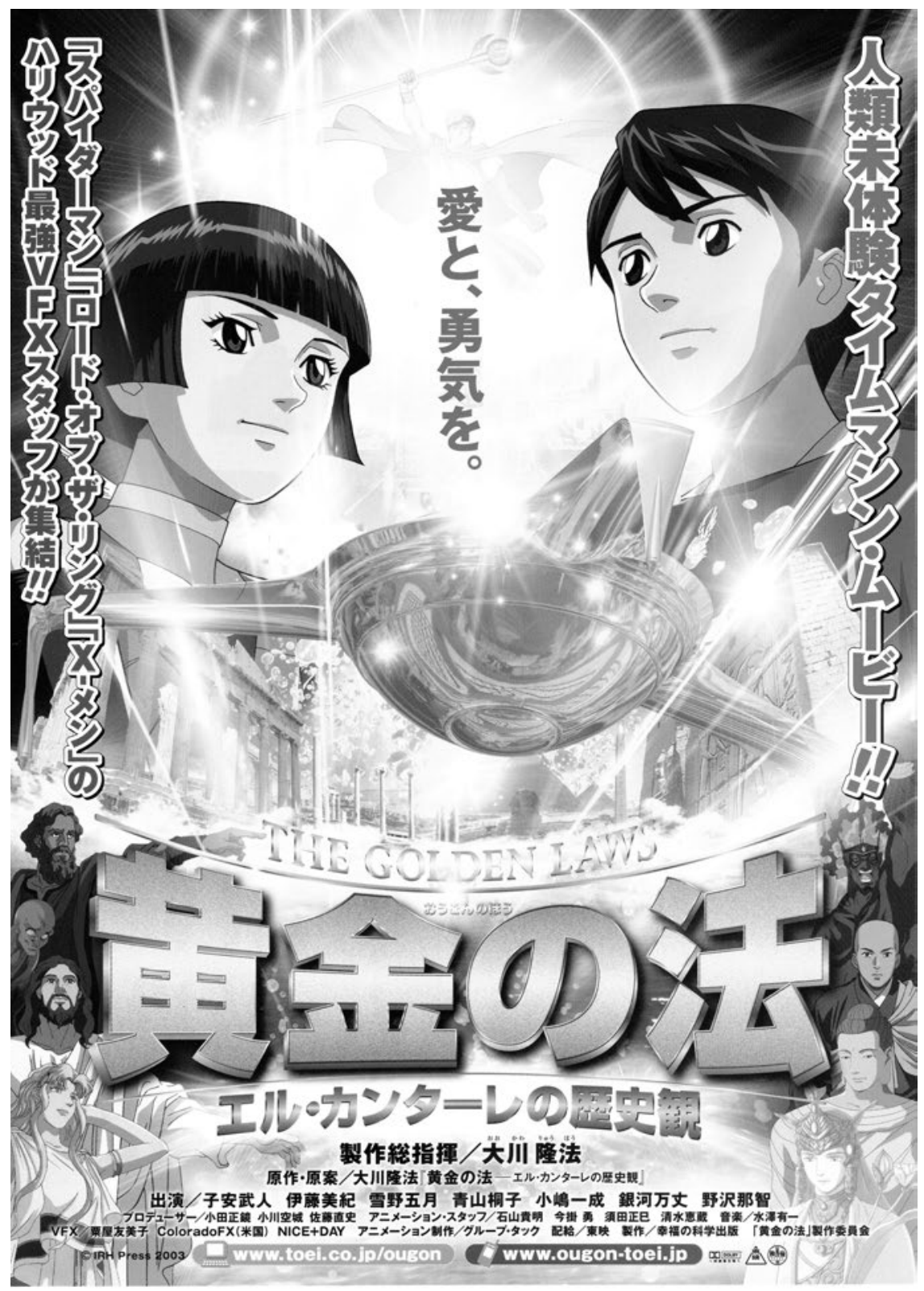

Fig. 1.4 Advertising material for Kōfuku no Kagaku's anime Ōgon no Hō ("The Golden Laws”), 2003. 
As far as broadcasting is concerned, several groups started their own radio programmes in the postwar period, following the introduction of the Broadcasting Law in 1950 (Enomoto 2006, 38). These include, for example, Konkōkyo's Konkōkyō no Jikan ("The Time of Konkōkyō") and Tenrikyō's Tenrikyō no Jikan ("The Time of Tenrikyō"), both started in 1951 (Ishii 1994, 323). ${ }^{57}$ Radio programmes are still used nowadays by several groups, often for weekend programmes with religious contents, such as Kōfuku no Kagaku's Tenshi no mōningu kōru ("Angels' Morning Call”), a thirty-minute programme started in 1991 and transmitted every Saturday and Sunday mornings. More limited has been the use of television by new religions, mainly due to the cost involved, but mostly due to the restrictive rules imposed by broadcasting companies on transmissions with religious content (Inoue 2012; Ishii 1994). ${ }^{58}$ One of the few examples in this context was the TV programme Hito-monokoto ("People and Things") by Tenrikyō started in 1962 and discontinued in 1988 (Ishii 1994, 323). Usually, even the groups' ceremonies are not broadcast on main television channels, except for some spectacular events, such as the fireworks organised on August 1st by PL Kyōdan in the Kansai area. More numerous are the examples of groups that, while not producing specific TV programmes, publicise texts or ceremonies through radio and television networks, or have expressed an interest in doing so. ${ }^{59}$

Satellite broadcasting has less restricted rules and from the 1980s, when satellite broadcasting started in Japan, several new religions have been using it for transmitting their public events or to communicate with members. The first group to implement the new technology was Agonshū, which signed a contract in 1987 with Japan Satellite Broadcast (Inoue 2012; see also Chapter Three in this volume). Risshō Kōseikai used a satellite programme to transmit ceremonies and conferences in 200 centres around the country, and similarly, satellite broadcastings have been used by other groups, such as Reiyūkai, Seichō no Ie, Tenrikyō, Shinnyoen, Sōka Gakkai and World Mate (formerly Cosmomate). ${ }^{60}$ Often, such transmissions could be seen at the centres of the groups concerned, but in some cases, they can be accessed at some designated members' houses, such as the katei kyōkai ("home church") established by Kōfuku no Kagaku, especially for members living in the countryside and with no access to centres in their vicinity. ${ }^{61}$ The use of media was often paired with the organisation of choreographed, multi-media events that attracted many viewers. The spectacular events organised by Agonshū and Kōfuku no Kagaku will be analysed in detail in Chapters Three and Four, respectively, but events organised by other, groups such as Sōka Gakkai and the GLA have also been widely advertised and attended. Events are at times recorded on DVDs (and previously on videocassettes) that are then viewed again and reproduced in the centres for training purposes, or to remind members of how active the group is and how many people it attracts during events. Similarly, leaders' speeches are often recorded and circulated. Videocassettes and now DVDs are relatively inexpensive items that can be created by non-professionals, so they are largely used by new 
religions. There are also a small but limited number of examples where new religions have invested in more costly ventures, such as the above-mentioned films by Oomoto and the recent animated movies by Tenrikyō and Kōfuku no Kagaku (Tsukada 2010). Videos are also utilised by many groups during their ceremonies; for example, in the GLA, some meetings called "visual sessions" (bijuaru sesshon) were set up primarily for viewings of the leader's speeches and explanations of the teachings. Some groups have also been using video to substitute for or integrate with printed newsletters to update members about recent activities and events, as with, for example Oomoto's Ōmoto Bideo Nyūsu ("Oomoto Video News") and Agonshū's Agon Nyūsu ("Agon News"). ${ }^{62}$ On August 1, 2014, for example, I attended an Agonshū ceremony transmitted via satellite broadcasting at its centre in Miyazaki city. After the ceremony, I was asked if I wanted to see the "Agon News" DVD for that month. The DVD showed the performance of fire rituals around Japan (in particular, in the Miyazaki and Tottori Prefectures) and encounters between the leader Kiriyama and other representatives with local religious leaders. When the ritual was performed in Miyazaki, for example, the Agonshū priest met with the head priest of Aoshima shrine, one of the main Shinto shrines in the area. The DVD concluded with a "personalised" message from the leader to his followers.

Since the 1990s, the Internet has been offering new religions new possibilities for presenting their teachings and reaching a wider audience, also at international levels. In 1999, I conducted an online search on 120 new religions, at which point twenty-five of them had a website (Baffelli 2000). Several new religions established their online presence in the late $1990 \mathrm{~s},{ }^{63}$ but the websites mainly replicated information provided in printed material, with very limited (or no) interaction with viewers. Nowadays, all groups tend to have a website and to engage to some extent with social media. However, thus far, new religions have tended to take a cautious approach to the Internet. As discussed in other publications (Baffelli 2011), one of the main reasons for this lack of use of new media has been the fact that the Internet, being an open-structured environment, is more difficult to control compared to other media, so that groups can be exposed to harsh and unpredictable critical attacks. ${ }^{64} \mathrm{~A}$ few groups, such as, for example, Hikari no Wa and Seichō no Ie, have recently started engaging more in social media, and this could represent a new development in the use of new media (see Chapter Five in this volume). What is important to note, however, is that, compared to the pioneering approach new religions have had toward other media, as illustrated in the brief overview provided, the approach to the Internet has been more prudent, if not even suspicious. This change can also be ascribed to the consequences of the 1995 sarin gas attack. Twenty years after the Aum Affair, new religions are still exploring new avenues and strategies for presenting their teachings and activities and restructuring their images. Expensive media campaigns and spectacular events promoted in the pre1995 period may now be seen as exposing the group to criticism. Very little 
data are available on the financial situation and membership figures of new religions, but it is possible to argue that decreasing or stagnating membership may also be one of concurrent causes in the decline of costly events and advertisings. New religions are also still confronted with the image of being "dangerous" in popular culture representations ${ }^{65}$ and in public discourse, especially on the Internet. For example, discussions about new religions in bulletin board systems such as the popular 2Channel (2channeru) tend to be extremely critical (Tamura and Tamura 2011). Therefore, the use of the media by new religions should be considered both in the historical circumstances of a specific group and in the broader context of the intersection between media and religion in Japan.

In conclusion, as Gardner notes:

The history of Aum Shinrikyō cannot be written without continual reference to questions concerning the relation of religion and media. The growth of Aum, for instance, might be charted by tracing Aum's development of a range of media forms (books, magazines, audiotapes, anime [animated films], manga, radio broadcasts, homepages, etc.) for use in both proselytizing and religious practice. Much of Aum's teachings might also be viewed as a recycled version of images, ideas, and notions circulated in a variety of forms by the mass media.

$(2001,133)$

Similarly, the history of other new religions cannot be written without considering how their media strategies were shaped by reactions to media reporting, but also by a process of mutual influence and borrowing between different religious groups and between the two spheres of media and religion. Indeed, religious groups influenced each other and borrowed from different contexts. For example, Agonshū promoted itself as the Japanese version of American televangelists (but with the claim that it was in advance of them), while Kōfuku no Kagaku's publications, events and advertising strategies were strongly influenced by other Japanese groups such as Agonshū, Sōka Gakkai, the GLA and Seichō no Ie, while also recalling the image strategies of non-Japanese groups such as Scientology. Risshō Kōseikai representatives mentioned in an interview with me that they have used the Catholic Church as one of their models for magazines differentiated by audience and so on. New religions have also borrowed media language and imaginaries, as with the publication of Nostradamus-related books and videos by Agonshū, Kōfuku no Kagaku and Aum Shinrikyō in the late 1980s and 1990s, ${ }^{66}$ for example, which followed the popularity of Gotō Ben's 1973 translation of Nostradamus's prophecies. ${ }^{67} \mathrm{New}$ religions have also promoted spectacular events that call to mind secular events such as artists' live performances, political events or sports competitions. These events also recall matsuri, or large traditional religious festivals, which are mass-media events that are often shown on mainstream television. 
At the same time, the media, at least until 1995, looked at new religious not only as unusual and potentially dangerous groups, but also as successful enterprises that could be exploited to attract audience attention. It is therefore inadequate to view the relationship between the two spheres as simply antagonistic or competitive. The interactions should be explored in the complexity of layers they involve in order to understand why media engagement is important for religious organisations in general, and even more so for groups whose developments have been parallel to that of the modern and contemporary mediascape.

\section{NOTES}

1. Director: Mori Tatsuya; producer: Yasuoka Takaharu. 136 minutes. Color. 1998.

2. The conversation is translated in the film's subtitles as follows: "I want you to look at us closely. I want you to record us. We don't have a tradition of recording things. Even if we did, people would see it differently because we made it. I want ordinary people, people who can understand, to see what they can see, to hear what they can hear".

3. For a discussion on the construction of "metaphorical foreigners" in the late Meiji period, see Gluck $(1985,135)$. On the "otherness" of new religions, see also McLaughlin (2012).

4. This insider/outsider tensions was particularly explicit in Aum. Although Araki seems to show respect toward Mori's role and allowed him into the facilities to film his documentary, when the director asked him at the end of above-mentioned scene, "Do you think I can see?" Araki can only laconically reply with a vague "Well ..." ("soudesune").

5. Director: Mori Tatsuya; producer: Yasuoka Takaharu. 131 minutes. Color. 2001.

6. For a detailed analysis on this episode, see Gardner 2001. For Mori's account, see Mori (2000).

7. For a discussion about terminology, see the Introduction in this volume.

8. On mass media in this period, see Huffman (1997) and Gluck (1985, 232-233).

9. On censorship, see Kornicki (1998); Mitchell (1963).

10. On the use of jakyō, see Dorman (2012a, 25); Ketelaar (1990, 42).

11. As pointed about by Dorman, inshi literally means "shrine of indecency" and refers to a "Confucian moralistic judgment implying sexual immorality and female promiscuity" (2012a, 25).

12. For a more detailed account of Renmonkyō history and teaching, see Dorman (2012a); Sawada (2004); Takeda (1991); on the conflict between Renmonkyō and the press, see also Inoue (1992, 47-56).

13. Furthermore, according to Dorman (2012a), the form of condemnatory reporting (danzai hōdō) developed by Yorozu Chōhō and other emerging newspapers at the time constitutes a predecessor of the form of reporting, often based on alleged scandals, of the weekly magazines that developed in postwar Japan (2012, 34).

14. On the formation of State Shinto, see Hardacre (1989); Murakami (1970; 1980); Shimazono (2010). More generally, on the history of Shinto, see Breen and Teeuwen eds. (2000); Teeuwen and Scheid (2002).

15. As previously mentioned, the term can also be translated as "immoral heresy".

16. On Oomoto's First and Second Suppressions in 1921 and 1935, see Berthon (1985); Staemmler (2009); Stalker (2008). 
17. The Rush of the Gods is also the title of one of the earliest works on postwar new religions by $\mathrm{H}$. Neill McFarland. This is another example of how influential media definitions of new religions have been for both public and academic discourses on these groups.

18. On phases of religious policy during the Occupation, see Dorman (2012a, esp. chapter 4) and Thomas (2014).

19. "Boom" is a loanword used in Japanese media to denote cultural, economic and fashion trends. According to Skov, "One side-effect of successive booms is the creation of a strong sense of here-and-now- which, at least to some extent, dispenses with the content and causality of what happens to be in style in a particular year. Indeed, the Japanese word boom refers to more than consumer trends: environmental problems, economic fluctuations, political issues, cultural debates-along with television series, writers and models-have been popularised and then forgotten according to the same temporal logic. This had led one scholar to go so far as to argue that Japan is in fact a "boom-based society' (Yoshimoto 1989:9)" $(1995,175)$.

20. On religious revival and shükyō bümu, see also Berthon (1997); Inoue, Komoto, Nishiyama, Umetsu (1985); Reader (1990); Yokoyama and Nishiyama (1988) and the Special Issue of Shisō to Gendai. Shūkyō no kakusei: Gendai no shūkyō būmu o dō miru ka (1988).

21. The volumes were reprinted in a three-volume series by Kadokawa Bunsho in 1989.

22. The first translation appeared in 1973 and met with considerable success (Kisala 1997).

23. Berthon and Kashio (2000, 76-77) compare seishin sekai (spiritual world) and shinreisei undō (new spiritual movements) to the New Age in North American and European contexts. On seishin sekai, see also Shimazono (1992a; 1992b; 1996; 2001a; 2007). On the New Age and spirituality in Japan, see also Horie 2011.

24. For example, see the article "Seishin sekai no hon' jiwajiwa ryūhō" in Asahi Shinbun, February 4, 1980.

25. A list of all events and publications using the term or covering topics related to Seishin sekai is available in the above-mentioned volume seven of Meiso Meditation published in 1982.

26. On the repercussions of the Aum Affair in Japanese society, see Kisala and Mullins (2001); and the Special Issue of the Japanese Journal of Religious Studies edited by Erica Baffelli and Ian Reader (2012). On public perceptions and attitudes toward religion in Japan after 1995, see Inoue (1999; 2003); Ishii (2007).

27. Examples of publications supporting these ideas are Nishida (1995); Takahashi (1995); Takimoto and Nagaoka eds. (1995).

28. For instance, Steve Hassan's Combating Cult Mind Control, written in 1988 about the Unification Church; Michael D. Langone What Parents Should Know. 1988; Phillip Zambardo. What is Mind Control? 1995. See Watanabe (2001).

29. In particular, two scholars, Shimada Hiromi and Nakazawa Shin'ichi, faced criticism after the sarin attack for perceived associations with and positive endorsement of Aum. Shimada lost his university position as a result.

30. For a detailed account on Aum Shinrikyō's members portrayals on Japanese television, see Kojima (2011); on journalist and academic reporting about Aum before 1995, see Kumamoto (2011); Tsukada (2011).

31. Forty to fifty hours every week, according to Hardacre $(2007,175)$.

32. The most striking example was the Pana Wave Laboratory (Panawēbu kenkyūjo), a small group founded in 1977 by Chino Yūko (1934-2006) and referred to in the Japanese media as "the white-clad group" (shirozukume shüdan). 
The group became the focus of a massive media campaign in 2002 and 2003 because of escalating conflicts with local residents and authorities in the Fukui and Gifu Prefectures. Some characteristics of the group (communal lives, emphasis on prophecies, members wearing only white clothes and so on) resulted in it being labeled as potentially dangerous and as the "next Aum"(Baffelli and Reader 2012, 13; Dorman 2005b).

33. Beat (Kitano) Takeshi (born 1947) is a Japanese TV personality and film director. He often appears in TV programmes discussing religious practices or supernatural phenomena.

34. World Mate (formerly Cosmo Mate) is a new religion founded by Fukami Tōshū (born Handa Haruhisa and known as Fukami Seizan, 1951-, in mid1984. In 1994, the group changed its name to World Mate. Fukami is a prolific writer, and his bestseller, Daikinun ("Lucky Fortune", 1991) has sold about a million copies worldwide (see Prohl 2004 and 2006).

35. Hō no Hana Sanpōgyō was established in 1987 by Fukunaga Hōgen (born Fukunaga Teruyoshi, 1945-). The group was dissolved in early 2000s following the arrest of the leader for fraud. The group was usually referred in the media as the ashiura shindan ("foot reading cult") because the leader claimed to be able to diagnose people's illnesses by examining the soles of their feet. (Baffelli and Reader 2012; Fujita 2008; Inoue et. al. 1996; Wilkinson 2009; Yonemoto 2000).

36. Founded by Kitamura Sayo (1900-1967) in 1945 and known as the "Dancing Religion" (Odoru Shūkyō) for the practice known as "dance of ecstasy" (muga no mai). See Dorman (2012a).

37. Personal communication with Mori Tatsuya, March 2015.

38. For some examples about the advertising of temples in Japan, see Reader and Tanabe (1998, 212-17); Reader (2014).

39. For examples of large funding invested by new religions in advertising in the early 1990s, see Iwasa $(1993,13)$.

40. The advertising campaigns covered newspapers, magazines (often occupying several pages), television and public transport.

41. In his overview on the use of media by new religions, Ishii (1994) also mentioned the publication by YTV Jōhō Sangyō Kenkyū Gurūpu (1975) that looked at several new religions as "information industries" ( $j \bar{o} h \bar{o}$ sangyō).

42. After the Hanshin Awaji daishinsai (Great Hanshin/Awaji Earthquake) that occurred on January 17, 1995, religious groups were criticised in the media and accused of not having offered solace to the people affected by the disaster.

43. Interview with representatives of Kōfuku Kagaku's Public Relations Department, July 2014.

44. Also, Thomsen quoted a report from the General Secretary of the Soto Branch of Zen Buddhism who was worried about the threat posed by new religions and their "astonishingly effective propaganda methods" (1963,31).

45. As an example, Risshō Kōseikai, one of the largest lay Buddhist movements in Japan, which was founded in 1938 by Niwano Nikkyō (1906-1999) and Naganuma Myōkō (1889-1957), has a publishing house and a department of external affairs that looks after the website and a specialised section for TV programmes. It also uses external experts as consultants.

46. In 1935, the group opened a movie studio in Tokyo and established a Sacred Film Division (Eiga shingekibu) in Kameoka (Stalker 2008, 132).

47. According to Berthon and Kashio, "Lorsque le group religieux accroît le nombre de ses fidèles et que son rayonnement dépasse les frontières villageoises, s'opère, souvent, un travail de réécriture des premiers écrits (réajustement du message en fonction de l'échéance messianique, mais aussi réorientation du mouvement dont les premiers écrits peuvent être, alors purement et simplement 
supprimés). Une attention très vive est portée a la forme légitime du discours écrit, devenu, a fil du temps, " écriture sacrée » et source de valorisation, par la mise en perspective avec une tradition revendiquée" (Berthon and Kashio 2000, 72).

48. Tsukada $(2010,74)$ uses a similar term for Kōfuku no Kagaku, which he defines as "a religion that publishes and produces literature" (shuppandokusho shükyō).

49. Similarly, in an interview conducted in 2003, a Risshō Kōseikai representative told me that the group had, at the time, different publications for different audiences: Yakushin for members, Dāna for senior members, Candela for high school girls and Ambition for boys (both issued every four months), as well as Donguri kurabu for kids and, finally, Dharma World, which was in English and included also contribution from scholars.

50. See the example of GLA magazines mentioned by Whelan $(2007 \mathrm{a}, 72)$.

51. Manga, or comics, occupy a significant sector of publishing in Japan. In the mid1990s (and up to 2005), manga represented roughly forty per cent of the print publishing market (Zenkoku Shuppan Kyokai/Shuppan Kagaku Kenkyūjo 2006). Although sales have declined over the last few years, the decrease seems tied to an overall drop in the publishing industry and in 2012, the reported sales of tankōbon (compiled book volumes) was still an impressive amount of 267.5 billion yen (See: http://www.animenewsnetwork.com/news/2013-0203/oricon/manga-volume-sales-dipped-1.5-percent-in-japan-in-2012, accessed July 21, 2015). These numbers do not include manga sold second-hand, manga read at manga kissa (cafés where, for an hourly fee, one can read comics, watch DVDs and surf the Internet) or at bookshops or manga exchanged between readers or the numerous dojinshi (amateur manga). Indeed, the Comiket (or komikku māketto, Comic Market), the largest dōjinshi fair started in 1975 and held twice a year (August and December) in Tokyo, attracts over 30,000 circles (publishing groups) and a large number of visitors (http://www.comiket.co.jp/ info-a/WhatIsEng080528.pdf Accessed July 21, 2015). Manga and anime are not consumed by an "average Japanese recipient" (Berndt 2008, 297), but they include different subgenres catering to specific audience targets (boys, girls, men, women). Some have also a large crossover readership.

Manga are usually first published as short episodes in weekly or monthly magazines. Some of them are later compiled into single volumes and organised in series. Some manga are also turned into anime (or, in a few cases, live actions film).

52. In his study on religious anime, Thomas (2009) divides religious narratives into two main types: aesthetic and didactic. Didactic products, such as, for example, proselytising videos or video used as teaching tools in religious meeting, are conceived to convert or to introduce religious doctrine, while aesthetic works "utilize religious vocabulary and imagery to promote affective responses ranging from casual diversion to strong conviction" (Thomas 2009, 205). Some anime (and similarly, some manga) skillfully combine the two elements and create "emotive" products (Thomas 2009, 206). On representation of religious themes in manga, see also MacWilliams (2012); Thomas (2012); Watanabe (2015); Yamanaka (1996).

53. The title is in English.

54. Generally, the examples of new religions' visual media distributed to the general public are quite limited, also due to the elevated cost involved in the production and distribution of movies. For other examples, see Tsukada 2010, 77.

55. To date, two movies produced by the group are not animated movies: Nosutoradamusu no senritsu no keiji ("The Terrifying Revelations of Nostradamus", 1994) and Fainaru Jajjimento ("The Final Judgement", 2012). The latter is the 
first movie produced by Kōfuku no Kagaku with an original script not based on previously published books.

56. http://www.toei.co.jp/ougon. The website is no longer available.

57. In the same period, other groups started radio broadcastings, such as Seichō no Ie, PL Kyōdan and Oomoto (Ishii 1994, 323). For a comparative analysis of the use of radio by Seichō no Ie and Konkōkyō in the postwar period, see Enomoto (2006). On Japanese religions' use of radio and television, see also Abe (1990).

58. TV broadcasting started in Japan in 1953. The first TV programme with religious content was Shükyō no Jikan ("The Time of Religion") broadcast by Nihon Terebi and Yomiuri Terebi in 1960 (Enomoto 2011: 75-76). For a comprehensive study on TV programmes with religious themes, see Ishii (2008 and 2010).

59. This interest was not limited to new religions. In 1987, the Agency for Cultural Affairs published a survey on the use of media by religious groups, comprising 241 religious groups (Bunkachō Bunkabu Shūmuka 1987). It emerged that one group out of five had sponsored radio or television programmes or had public relations activities and that many groups are willing to utilise the mass media for propaganda purposes. Even though the report concerns not just new religions, it shows how the use of video, radio and television in that period was still quite limited.

60. An article in the Asabi Shinbun on June 4, 1992 listed the groups that make use of satellite transmissions: Sōka Gakkai, Risshō Kōseikai, Agonshū, Shinnyoen, Sekai Kirisuto Kyōitsu Kyōkai, Kōfuku no Kagaku and Aum Shinrikyō. Quoted in Maeno (1994, 78-81).

61. Interview with representative of Public Relations Department, July 2014.

62. Video newsletters were also used by PL Kyōdan, Ennokyō and Shinnyoen (Ishii 1994, 328).

63. For example, MOA Sekai Kyūseikyō, 1995; Agonshū, 1997; Risshō Kōseikai 1998; PL Kyōdan 1999 (Baffelli 2000).

64. On Japanese religions online, see Baffelli, Reader and Staemmler (2011); Enomoto (2012); Fukamizu (2007); Ikegami and Nakamaki eds. (1996); Inoue (2000) Inoue ed. (2003); Kawabata and Tamura (2007); Kienle and Staemmler (2003); Kurosaki (2007); Kurosaki et al. eds (2000); Porcu (2010); Staemmler (2011).

65. For a discussion of representations of new religions in manga after 1995, see Thomas (2012).

66. For instance, Kiriyama of Agonshū published the book 1999 nen karuma to reishō kara no dasshutsu ("Escape From Harmful Spirits and the Karma of 1999") in 1981; Asahara of Aum published Nosutoradamusu himitsu no daiyogen. 1999 nen no nazo ("The Secret Prophecy of Nostradamus. The Enigma of Year 1999") in 1991 and a movie version of the book in 1992. Ōkawa of Kōfuku no Kagaku published his first book on the topic in 1987, Nosutoradamusu no shinyogen. 1999 nen to daikyūseishu no kōrin wo kataru ("The New prophecy of Nostradamus. Telling the Year 1999 and the Advent of Great Messiah") and a second book on prophecies, Nosutoradamusu no senritsu no keiji ("The Terrifying Revelations of Nostradamus"), in 1991 (Baffelli and Reader 2011, 11-12). The former work by Ōkawa in particular borrowed extensively from Gotō Ben's 1973 book (Baffelli and Reader 2011; Kisala 1997).

67. The book Nosutoradamusu no daiyogen. Semarikuru 1999 nen 7 no gatsu, jinrui metsubo no bi ("The Great Prophecies of Nostradamus. The seventh month of 1999 is hanging over, the day of humankind destruction") by the journalist Gotō Ben was published in Japan in 1973 and became a bestseller. Several other books, magazines, manga, films and animated movies on the topic were produced, including 10 subsequent books by Gotō himself between 1973 and 1998 (Baffelli and Reader 2011, 11; Kisala 1997). 


\section{The Importance of Media Engagements Themes}

\section{INCREASING PROFILE, IMPROVING IMAGE AND RECRUITMENT}

The outline presented in the previous chapter showed how the nexus between new religions and media technologies has developed and how media literacy has been an important instrument for the expansion of these groups. In particular, as the case studies discussed in the following chapters will elucidate, image strategies are particularly relevant at the initial stage of formation of religious organisations, when groups need to develop from an early stage of a small circle of interested people, usually formed around a charismatic teacher and leader, into a more distinctly defined and structured religious institution. As discussed in the Introduction, new religions usually refer to or locate themselves within an existing tradition to claim their legitimacy and to build their reputation, but at the same time, they need to offer a new innovative path and to increase their visibility in the religious marketplace. Media engagement can therefore become a vital element to determine the development and success of these groups.

Consequently, the first thematic issue in the analysis of media and new religions in the Japanese context is the opportunity offered by the media to increase a group's public profile, improve its image and, ultimately, attract new members. Effective media use can play not just an important role but in fact a central one in creating, reshaping and innovating the identity of new religions. New media technologies create new opportunities for disseminating teachings and reaching wider audiences. As discussed by Stalker (2008), for example, visual media were instrumental in Oomoto's rapid expansion in Japan under its second leader, Deguchi Onisaburō:

Onisaburō foresightedly recognised the power of visual images and the increasingly influential role they would play in modern religious life. Oomoto used visual technologies and images to engage in market differentiation, tailoring its message according to audience: art exhibitions emphasised the versatility, spirit, and genius of its charismatic leader and the promise of art for everyman; expositions stressed the sect's modern 
and international character, its status as an educational, humanitarian body that transcended the Japanese state; newsreels and movies featured Shintoist rituals and traditional arts during an era in which many Japanese sought a return to traditional Japanese culture as a stable form of national identity.

(Stalker 2008, 139)

In the 1980s, Agonshū used spectacular public events, widely advertised and magnified by state-of-the-art technology, to raise its profile as a "religious movement very much at home in the modern world" (Reader 1991, 219) and to attract the attention of the general public. Similarly, Koffuku no Kagaku's rapid expansion in the late 1980s and early 1990s was due in part to its large use of advertising in public spaces and use of slogans and catchphrases in the style of commercial enterprises (Astley 1995; Baffelli 2005 and 2007). Sōka Gakkai also maintains a high level of visibility, and its new publications are advertised in trains, shops and other public spaces such as screens at major crossroads in Tokyo (as described in the Introduction). Media forms are therefore used to "promote a desirable self-image in the public eye" (Stalker 2008,100) and to generate interest beyond the circle of adherents.

Media are also important to increase members' cohesion and enhance the image of the group internally. The "media empire" (McLaughlin 2009, 18) created by Sōka Gakkai, for example-which includes the daily newspaper Seikyō Shinbun, ${ }^{1}$ magazines and publications, visual media, music, websites-not only engages members in media-related activities (such as distributing newspapers), but also frames what kinds of information are received by members (McLaughlin 2009, 18).

At the same time, the creation of positive images and the distribution of group-specific narratives are also important for existing members. For example, movies and videos produced by new religions are often made for internal use and employed for training purposes during seminars and meetings. In the case of Agonshū and other movements, videos of public events are also available at their centres to be watched by visitors and to demonstrate the group's ability to attract large audiences. In the case of the anime (animated movies) produced by Kōfuku no Kagaku and mentioned in Chapter One, they are apparently produced to reach a wider public, as they are screened in cinemas throughout Japan and advertised with large campaigns and multimedia strategies (books, magazines, soundtrack CDs, DVDs, collectables, TV advertising). Tsukada (2010, 18), however, notices that the main purpose of such animated-movie production seems to be to demonstrate to members that the group is reaching its objectives and to convey a sense of achievement and affirmation. Therefore, in this case as well, media activities like anime are mainly intended for existing members to both reinforce their loyalty (with the distribution of free tickets, for example) and strengthen their interest by showing the movement's ability to create and invest in costly media productions. 
At the same time, as public media are important sources of knowledge about religion, they have also created a space within which religious organisations have "to act as their own advocates or defend themselves from public criticism" (Lynch and Mitchell 2011, 1); this is especially important for new religions because of general public mistrust (see discussion in Chapter One of this volume). As a consequence, media literacy is becoming a vital skill for the survival of these groups. New religions' media strategies have to be sophisticated to enable the difficult balancing act between being exciting, exotic and different (for example, by offering the possibility to achieve extraordinary spiritual powers, or promising attractive miracles and benefits) without appearing too peculiar or demanding too much of potential followers. An example of a movement that failed to manage this balance and ended up developing a very negative image as a result was Aum Shinrikyō. As discussed in Chapter One, media external to the group played a crucial role in the initial development of Aum. When the magazine Sunday Mainichi in 1989 published interviews with concerned family members, Aum was also able to launch a "charm offensive" (Reader 2000a, 38) in order to use criticism as a chance for self-promotion (Dorman 2012a, 10-11; Hardacre 2007, 185). Asahara appeared in several interviews and TV programmes and the group demonstrated its ability to turn the critical portrayals to its favour. However, in the aftermath of the subway attack, the group's unusual practices generated sensationalist accounts and Asahara became the "personification of evil" (Reader 2000a, 34). Aum representatives initially attempted to deny their involvement in the criminal actions, but after the leader and top members were arrested, the remaining members were left without a clear direction to face media attacks and public condemnation, and their inability to explain Aum to the outside world became evident. ${ }^{2}$

Other new religions have been more successful in constructing an image of a media-savvy and up-to-date religion, especially in the pre-1995 period. Agonshū, for example, emphasised its ability to use media in advertising campaigns. Reader, for example, cites an advertisement sponsored by Agonshū in the Mainichi Daily News on October 15, 1987, in which the group is described as a "user-friendly religion":

Kiriyama Seiyū consciously interprets Buddhism into a language that young people can relate to-thus the satellite broadcasts, the modern temple building, his friendly sermon and his approachable manner. All this adds up to a user-friendly religion appropriate to the needs of the modern Japan.

$(\text { Reader 1991, 219) })^{3}$

Similarly, for Kōfuku no Kagaku, the development of media engagementsfrom the foundation of its publishing house, to the establishment of its first magazine, radio broadcast, animated movie and so on-is part of a narrative 
used by the group to appeal to the general public and to reinforce the idea of being part of a successful and modern group to adherents. ${ }^{4}$

Finally, terminology related to new technologies is also used by leaders to explain teachings and doctrine, while demonstrating their ability to use an accessible and easy-to-understand language. Seichō no Ie's founder, Taniguchi Masaharu, for example, encouraged the use of radio in the postwar period. For Taniguchi, radio was not just a means of propaganda, but he also used the metaphor of "tuning" in to radio waves to explain the mind reaching the "divine nature" (naibu shinsei or bontō no jibun, "true self") and defined the meditative practice of shinsōkan, ${ }^{5}$ the most important ritual in the group, as an "antenna for spiritual exchange" (reiko no antena, Enomoto 2006). ${ }^{6}$ GLA's founder Takahashi Shinji, too, used a media-related metaphor to explain teachings, creating an overlap between media and religious languages. Referring to a technology that was new at the time, Shinji preached the idea that the soul was "a videotape on which all past lives had inevitably been recorded"7 (Whelan 2007a, 113) to explain his practice of past-life glossolalia. Therefore, by using modern media technologies, new religions tend to employ modern language forms and thus project an image of modernity compared to the more archaic language used by other religious institutions, in particular Buddhism. A recurrent comment by members I have heard during my visits to different new religions over the years is that the language used by leaders, as well as the language used in prayers and rituals, is a language that is accessible and easily comprehensible (wakari yasui) to anybody. Media therefore offer new religions not only convenient technologies to make their name and teachings known to a larger public, but also a new language for branding their images and conveying a sense of modernity and innovation.

\section{RELIGIOUS AUTHORITY: SHOWING CHARISMA IN THE MEDIA}

The use of media may be suitable for circulating religious ideas and promoting a religious group's image, but it also raises important questions regarding religious authority.

The presence of a charismatic leader proposing a new vision has been one of the main characteristics attributed to new religions. ${ }^{8}$ The most-cited definition of charisma is that provided by sociologist Max Weber (1864-1920), who defines charisma as:

[...] A certain quality of an individual personality by virtue of which he $[s i c]$ is set apart from ordinary men $[$ sic $]$ and treated as endowed with supernatural, superhuman, or at least specifically exceptional powers or qualities. These are such are not accessible to the ordinary, but are 
regarded as of divine origin or as exemplary, and on the basis of them the individual concerned is treated as a leader.

Charisma is portrayed as an anti-traditionalist and potentially revolutionary force (Comaroff 1994; Weber 1946, 249). At the same time, charisma is described as unstable and prone to deterioration, because it is based on recognition of the leader by the members and on their emotional involvement. Therefore, leaders are forced to constantly prove their legitimacy and success to members in order to maintain their authority. Several studies have debated the definition of charisma and charismatic authority, evaluating the complexity of relations between leader and members. Stalker (2008), for example, draws attention to the entrepreneurial character of charismatic leadership in Oomoto. According to her definition, "charismatic entrepreneurship" involves a "combination of spiritual authority, an intuitive grasp of the religious marketplace, savvy management skills, and a propensity for risk taking"(Stalker 2008,3) and it represents one of the key elements of successful new religions in the context of the competitive marketplace of religion (Stalker 2008,15). Chilson (2014) discusses the importance of the identification of members with the leader and the centrality of the mentor-disciple relationship in Sōka Gakkai. Feuchtwang emphasises the importance of institutionalisation, not as something opposed to charismatic authority, but as something suitable for reinforcing charisma and realising the vision shared between members and leaders (2008, 92). Finally, Csordas (1997) interprets charisma not as "a quality, but a collective, performative, intersubjective self-process" $(1997,140)$. Also important is the relational aspect of charisma, as it is constructed in and dependent on the dynamics between leader and followers. Therefore, it is not a one-way process, as followers' responses to mediatised projections of the leader are also important.

The case studies presented in this book explore these aspects-the performative aspect of charisma, the importance of entrepreneurial skills, the role played by religious intermediaries and institutions and the importance of the process of identification with and devotion to the leader-through a discussion of how media could impact religious authority and on the relationship between members and leaders. Media representations and visual culture play a central role in modern societies in the construction of a leader as a "bricoleur of heroic roles, religious symbols and stories" (Feuchtwang $2008,94)$ and in popularising and framing narratives centred around the leader. As mentioned in Chapter One, for example, printed media are crucial to the transformation of leaders' writings into a stable canon. They are also pivotal in reinforcing the emotional involvement of both leaders and followers in the vision and "expectation of the extraordinary" (Feuchtwang 2008, 103), especially when the group is expanding and direct contact between them is no longer feasible. Therefore, it is important to ask: how are mediation practices impacting the relationship between members 
and leaders and the perception of proximity between them? The case studies I use in this book refer in particular to primary charisma, that is, the charisma of the founding leader, and not to the secondary charisma of the successor. ${ }^{9}$ New forms of mediation offer immense potential for enhancing a leader's status, presenting him/her as a multi-talented entrepreneur and a visionary and pioneering leader in using media. Indeed, the leader is generally projected by the group as its main visual focus, and this in turn further develops the relationship between the leader and followers, for whom the leader becomes an ever-accessible visible presence. The following chapters will explore these issues by investigating the mediation of the leader-members relationship through satellite broadcasting (Agonshū, Chapter Three) and videos (Kōfuku no Kagaku, Chapter Four), the construction of a new idea of leader (Hikari no Wa, Chapter Five) and the attack on authority and attempt to "de-sacralise" the image of the leader through defamatory attacks to his persona (such as, for example, the vilifying reporting about Ōkawa Ryūhō that led to the Kōdansha Friday Affair; see Chapter Four in this volume).

Media could offer important tools for shaping leader-member relationships, encouraging emotional involvement and the internalisation of "models" of conversion and "ways of life". The autobiographical accounts in Ikeda's diaries (Chilson 2014) or Jōyū's blog (Baffelli 2011), for example, create a sense of intimacy through the sharing of everyday life. Through these accounts, the readers can identify themselves with the leader as "someone with whom readers can relate, and who readers can imagine as relating to them" (Chilson 2014, 74). Social media, in particular, can create the image of a close, familiar leader who is engaged in a direct dialogue with members, in contrast with the distant, inaccessible leader presented in other groups (see for example, the shift in leader's presentation from Aum Shinrikyō to Hikari no Wa discussed in Baffelli 2011 and in Chapter Five in this volume). In the case of Hikari no Wa, for example, the leader's engagement with social media such as Mixi or Twitter has created new spaces in which to reposition authority and affirm alternative ways of interaction between the leader and his audience. Similarly, conversion stories used in groups' publications that emphasise practical guidance for everyday life (discussed later in this chapter) could reinforce the authority of the group and strengthen the internalisation of its ethics and values, and its visions regarding inter-personal relationships and society. Finally, the relationship between members and the leader can become virtual, offering a way to overcome the limits of physical proximity. As movements grow, indeed, leaders' direct contact with members, such as direct one-to-one healings, initiations and so on, decrease. This leads to the development of structures with intermediaries, such as a board of directors or local leaders, who may gain some power and have some control on how messages from the leader are communicated to the members. New media therefore can offer leaders a way to interact directly with followers without intermediaries that could also potentially challenge their authority. 


\section{The Importance of Media Engagements}

At the same time, media practices can be used to create the image of a semi-divine leader (see Chapter Four in this volume) and to protect his/ her "aura" from criticism, making most of his/her contact with the public become mediated through the screen. Media can both protect the aura of the leader, but also make him/her more vulnerable and open to attack. As discussed in Chapter Four, for example, the overexposure of Ōkawa in the early 1990s triggered criticism and attacks from newspapers and magazines. Other studies have also examined how leaders have been cautious in using the Internet because of the risk of criticism (Baffelli, Reader and Staemmler 2011). For Benjamin (1970), the aura of a piece of art lies in its distance from the audience (Meyer and Moors 2005, 17). Similarly, the aura of the charismatic leader may be attributed to his/her distance (in the sense of "extraordinary quality", but also physical and spatial distance) from the members. Therefore, the "reproducibility" of a leader's image and its visibility and accessibility may be a danger for its aura, although visual culture and mediation practices (such as the satellite broadcasting discussed in Chapter Three and videos analysed in Chapter Four) can also play an important role in relocating the aura, which may have not disappeared, but, as pointed out by Meyer and Moors, may be "being reconstructed through new techniques of representation" $(2005,17)$ :

[...] In the era of media globalization the aura is re-embedded and reactivated in the place and time of the beholder, through its reception, thereby legitimating social authority through the medium of visual culture.

(Meyer and Moors 2005, 17)

An interesting example about how media technology could affect leader-member relationships and also transform the role of intermediaries is provide by Sōka Gakkai, the lay Buddhist movement founded in the 1930s by the educator Makiguchi Tsunesaburō (1871-1944) and considered the biggest religious organisation in Japan. In the 1950s, the second leader, Toda Jōsei (1900-1958), introduced monthly meetings for local leaders (bonbu kanbukai) in Tokyo. In the 1960s and 1970s, under Toda's successor Ikeda Daisaku (born 1928), these meetings were usually held at large facilities that could contain a considerable audience. The meeting included representatives from all of Japan's Prefectures and the aim was to share information and to report back to members in their area about guidelines that they were in charge of. In the 1980s, the meetings were suspended due to the high cost involved in their organisation, and for around three years, they were held via audio conferences. The communication in this case was unidirectional and the representatives were only able to listen without the possibilities of dialogic interactions. Although practical, according to Sōka Gakkai’s representatives, this system was not perceived as very "inspirational" by local leaders. ${ }^{10}$ In the late 1980 s, the group decided on a joint venture with 
communication companies and on August 24, 1989, the meeting was transmitted for the first time live from Sōka Gakkai's headquarters via satellite broadcasting. After the first transmission, however, it was decided that the meetings were going to be recorded and broadcast some days later. According to the group's representatives, the introduction of satellite broadcasting in the 1990s strongly affected the role and authority of local leaders. Previously, information and directives from the headquarters were transmitted to the members via the representatives, who were in the powerful position of being in control of this information. With satellite transmission, their mediation was not needed anymore and members could see and listen to Ikeda directly. Therefore, the new technology facilitated the feeling of direct contact with the leader and made it harder for intermediary figures to maintain their authority. The introduction of the new technology also facilitated the process Sōka Gakkai started in mid-1970s of "transformation from an organization headed by Ikeda into a group devoted completely to Ikeda Daisaku" (McLaughlin 2009, 108-109). Consequently, the sole authority of Ikeda became perceived as "less mediate" through the mediation practice of satellite broadcasting, and the practice is still commonly used nowadays. ${ }^{11}$

These broadcasts also allow members to witness interactions between the leader Ikeda and senior local leaders. During an interview I conducted with representatives of Soka Gakkai International and Sōka Gakkai Academics Affairs Division, it was stressed that the feeling of "being there with the leader" is more important than just reading texts and that this is one of the main positive aspects of satellite broadcasting. ${ }^{12}$ The transmission is usually one hour long ${ }^{13}$ (although the actual meeting is usually longer) and it is transmitted only at Sōka Gakkai centres in Japan. ${ }^{14}$ Programmes are usually showed for four days at specific times, so that members can choose the time that is more convenient for them. Similarly to other videos produced by new religions (see the example of Agonshū in Chapter Three), Sōka Gakkai broadcasts can only be watched at the centre, not in private homes. The broadcasts are open to external audience, but they are strongly encouraged to attend the group's beginners' programme or face-to-face discussion groups as well. Indeed, a strong emphasis is placed on face-to-face interactions, and introductions to its teaching are mainly done via personal contact and direct interaction. Therefore, in the case of Sōka Gakkai, satellite broadcasting seems to have been used to reinforce the inspiration and commitment of members, more than as a proselytisation tool. Indeed, as previously discussed, the use of mediation practices is not necessary limited to practices of external promotion and proselytism, but may be introduced to support internal changes and transitions.

In conclusion, when discussing the impact of media on religious authority, the focus is again on the need for a religious leader to be "visible", as a proof of the validity of his/her teachings and as a means of legitimation of his/her vision. The fluidity of charismatic authority creates the necessity for a leader to constantly demonstrate his/her approachability and to be able to 


\section{The Importance of Media Engagements}

able to innovate and to use new technology, while at the same time, media exposure raises issues about the protection of the leader's image and about the risks associated with damage control from critical attacks. Finally, the leader's lectures recorded on DVDs or other media can become part of the canon and used in ceremonies and practices after the death of the leader, so as to maintain the connection between the members and the founder. ${ }^{15}$

\section{IMPACT ON PRACTICES, RITUAL, SPECTACLE}

Another theme considered in the case studies is how various media forms could affect religious practices. As pointed out by Meyer and Moors in the introduction to an edited volume on Religion, Media, and the Public Sphere, "there is nothing entirely new about the link between religion and the media" $(2005,7)$ as religion could only exist as a form of mediation, through a book, a prophet or a founder acting as mediators between supernatural entities or forces and believers. However technology can create new forms of mediation practices or have an impact on existing ones. The ways in which this can occur will be discussed in later chapters, where I show how specific changes in various religious groups' practices have been influenced by the use of media. Examples include practices created to fit a particular new technology, such as, for example, the new version of the fire ritual introduced by Agonshū to fit the broadcasting timeslot the group had access to (Chapter Three), or how the use of media impacted internally on the relationship between leaders and members, as previously discussed. One of the central questions is about what occurs when a ritual is not merely transmitted by the media, but when the media also enables viewers to participate via the screen. Through the media, rituals can become spectacle-oriented, stressing artistic performance and theatrical enactments (as illustrated by the use of satellite broadcasting of annual rituals by Agonshū in Chapter Three), in order to entertain followers and spectators-an association that, along with entertainment, has been seen as "crucial" for the survival of contemporary religion (Meyer and Moors 2005, 15). Ritual is not only recreated as spectacle, but also consumed via the media; Agonshū members, for example, will gather together in their centres and participate in the ritual via the screen. The media can make the ritual more accessible, allowing members who are living in remote centres or abroad to participate in it and have direct visual access to their leader, and it could help to foster the image of a cohesive, large organisation. At the same time, rituals that are media events are also spectacles in which believers are simultaneously spectators. They are not, however, simply passive, but actively involved as spectators and believers in the ritual performance, something that will be developed further in Chapter Three.

Large public events have been organised by several new religions to promote devotion to the leader and to exhibit their power and wealth. ${ }^{16}$ Sōka Gakkai, for example, started organising mass performances in the postwar 
period under its second leader, Toda Jōsei. After Toda's death in 1958, his successor, Ikeda Daisaku, continued the use of mass performances and in 1964, the first Sōka Gakkai "culture festival" (bunkasai) ${ }^{17}$ was held under Ikeda's leadership at the National Stadium in Sendagaya, Tokyo:

One hundred thousand people filled the stadium; fifteen thousand performers swirled around the grounds in gymnastic routines, and thirty thousand people in the stadium seats created images of Mount Fuji and other symbols by holding up large flash cards. Three years later, Sōka Gakkai staged an even larger event at the same stadium, this time with forty-two thousand 'human letters' (hitomoji) flashing images of famous paintings, gardens, and finally the words 'world peace' in seventeen languages, as Gakkai performers from all over Japan and branches overseas danced in formation on the field by the thousands.

(McLaughlin 2009, 107)

In the 1970s, grandiose media spectacles in which hundreds of followers and artists performed in dances and elaborate choreographies ${ }^{18}$ were organised throughout the country, ${ }^{19}$ and supported the affirmation of Ikeda Daisaku as Sōka Gakkai's central and sole authority (McLaughlin 2009, 108). As will be discussed in Chapter Three, Agonshū staged spectacular rituals ${ }^{20}$ that were widely advertised and used in the 1980s to construct an image of a wealthy and powerful religion able to adapt traditional performances in a modern setting, and of a religious leader who was a skilled ritual practitioner with vital teachings for the modern day. These events were also a means of recruiting new members, by attracting visitors and impressing them with spectacular performances. Grandiose spectacles with staged and rehearsed performances also characterised Kōfuku no Kagaku events in the 1990s. Its first event, examined in Chapter Four, was organised in July 1991 on the occasion of the birthday of its leader, and after that, several other festivals were instituted. During these events, its leader performed in different costumes, and dramatic choreographies were accompanied by members' performances and parade. These events became well known and widely commented upon in the media for their grandeur and ostentation. Astley, for example, described the El Cantāre Festival held on December 26, 1991 as "Disneyesque":21

In the first part of the program, after the obligatory fanfare for passing the five-million-member mark, the various divisions in turn took to the stage. The Women's Division, representing love or family harmony, appeared first along with children dressed as angels and figures dressed as Disneyesque characters, to the accompaniment of nursery-rhyme music and clouds of bubbles. Next the Senior Division, representing Shinto and indigenous culture, appeared with the Seven Gods of Fortune to stylised Japanese music. Finally the Youth Division appeared, symbolising vigour and strength, and perhaps the purity of youth in 
their clean-cut attire. These Warriors of Light performed a rousing song titled Tsudoe, hikari no tenshi [Gather, angels of light!] to the accompaniment of what I would loosely describe as military music, punching the air with gold, then-dramatically at the climax of the song—red, blue, and white handkerchiefs.

$(1995,362)$

An important predecessor of Kōfuku no Kagaku's events were the performances of Takahashi Shinji, the GLA's founder, which created a strong emotional involvement and exchange between the GLA's leader and his followers and were characterised by the supposed transformation of Shinji's sweat into flecks of gold that followers "scrambled to collect on their handkerchiefs" (Whelan 2007a, 114). Dramatic events became a characteristic of public performances of Shinji's successor, his daughter Keiko, as well.

On January 25, 2004, I attended the GLA's Shinnen no Tsudoi ("New Year Gathering") held at the National Convention Hall at Pacifico Yokohama, a large convention centre in Yokohama city. The most anticipated moment of the ceremony was the final speech by the leader. As preparatory stages to her lecture, other teachers introduced elements of the GLA's doctrine, and a video showing Keiko's interactions with members was shown. When Keiko appeared on stage, the set was totally changed and revolved around lighting effects that drew attention to her figure and her words. Her elegant clothes, pure white, in perfect harmony with the set, and her movements created the image of a strong and determined woman, but also compassionate and caring. The voice, however, unwavering and quite loud in tone, grasped the attention of the audience. Keiko reproduced live a staged dialogue with a follower-aimed at a sort of "awakening of awareness of one's potential"similar to the interaction shown in the video in the first part of the ceremony. She started an intense "spiritual dialogue" (shinri jissen) with a man called from the audience, narrating his past difficulties and troubles and enthralling him not only with a peremptory and rapid way of speaking, but also through physical contact, touching him on the shoulders and arms. ${ }^{22}$ The audience's emotional involvement was such that not only did the follower on stage burst into tears, but so did many of those present. After the public conversation, during the handing out of a "truth card" (shinri card) to preselected groups of members, short conversations were allowed with the leader, demonstrating the importance given by the group to constant, direct contact between members and teachers.

The impact of media on ritual and practices, therefore, is not simply as an intermediary, but as a mediating force with the power to transform what is transmitted and to redefine how religious rituals are presented and consumed. Media-centred ritual performances and practices can project the image of a powerful group, boost the image of leaders, and create bonds directly between him/her and followers. They can also, however, produce negative responses, as the dramatic and spectacular projection of religious 
rituals and excessive displays of attention- grabbing performances and events may negatively convey the image of a highly ambitious leader and of an overly materialistic organisation. I will discuss this issue further below, but here will just note that this further indicates how media can be a dual-edged mechanism, offering both potential for the development and reinforcement of a movement's strengths and a leader's charisma-and a potential means of generating criticism.

\section{BRANDING NARRATIVES: MEDIA AND CONVERSION STORIES}

A further important aspect in the use of media forms by new religions is the creation of testimonies and conversion narratives. The use of narratives centred on members' stories and teaching explanations through daily life examples are often found in new religions' publications, such as magazines, comics, videos and websites. These accounts are initially presented at meetings and then eventually published. Many of these testimonies express teachings concretely as being applicable to daily life and describe how difficulties can be overcome through faith. The stories are repeated at different meetings, from small to large and medium groups, and while repeated they are polished into a more coherent corpus that can then be published. According to Shimazono $(1986 ; 1993)$, such conversion stories, despite focusing on individual experiences, tend to become "standardized and uniform" (Shimazono 1986, $161)$ and as pointed out by Watanabe (2011) create a "model" for members:

[...] testimonials which have been told repeatedly become internalized by the persons in question as their conversion stories based on the religion's system of beliefs, while additionally they serve as essential factors in offering conversion models for other members including ways of attributing meaning to certain situations and strategies of coping with them.

(Watanabe 2011, 78)

Kawakami (2008) explores how World Mate, Kōfuku no Kagaku and Agonshū developed the conversion tales found in their magazines and shows that there is a uniformity of style within each religious group. He also points out how verbal and written accounts may differ, with stories being written to shape how members think about their conversion and to attract potential new members. Media narratives and meeting performances therefore construct a narrative of testimonies and a "model" of conversion that becomes the "blueprint for members to interpret their own life experiences" (McLaughlin 2009, 139) and allows members to identify their individual goals with those of the organisation. The publications become what McLaughlin calls "a participatory canon", in which standards of conduct and moral values are explained and members can become exemplary models themselves. 


\section{The Importance of Media Engagements}

One of the media forms that has been used to convey testimonial and conversion narratives is manga, or comics. In manga, visual and written texts are combined together to create "multimodal texts" (Orcutt 2010, 94) in which the reader is required to "fill in" the gaps and details, such as, for example, the sounds and dialogue between characters or the temporal succession between sequential panels. Manga narratives create a multi-sensorial experience through the use of rhetorical figures, onomatopoeia and cinematic techniques (such as close ups). An important aspect of the iconic power of manga is its being a participatory media (Orcutt 2010,98) that creates immersive narratives. The reader is deeply involved in the narratives and identifies with the characters and their imaginary words. These characteristics of manga seem suitable, according to Orcutt, for the type of narratives familiar in religious traditions, narratives aiming to explain teachings or to offer exemplary role models and provide moral guidance (Orcutt 2010, 98).

The manga series Manga de Miru Kōfuku no Kagaku ("Kōfuku no Kagaku in Manga"), which includes four volumes, was initially published between 1992 and 1994, and it is an example of the presentation of conversion tales in manga.

The first volume (Tengoku no Mon, "The Gate of Heaven"), published in 1992, presents an introduction to Ōkawa Ryūhō's teachings. It includes four chapters drawn by four authors with a prologue, and intervals illustrated by a fifth author. ${ }^{23}$ Each chapter focuses on one of the Principles of Happiness (Kōfuku no Genri) constituting Kōfuku no Kagaku's yonshōdō (Fourfold Path, see Chapter Four in this volume): ai (love), chi (wisdom), hansei (self-reflection) and hatten (progress).

The first page shows an image of an imposing door marked by the group's logo (which was created in the early 1990s) and illuminated by a radiating light. The door slowly opens on the second page and a man appears and welcomes the visitor-reader to the "gate of heaven". The man (who, as we will discover at the end of the volume, is an angel in disguise) makes immediately explicit his role as a narrator. The choice of having an internal narrator who comments on the events described is unusual in comics, but in this case, it is used to engage the reader and to enhance his/her emotional response and identification with the manga's main characters. The omniscient narrator, indeed, does not simply report the stories, but he addresses the reader directly, looking at him/her as if he was looking at a camera. The narrator asks questions to the reader and "listens" to his/her answers. He shows interest and wants to grab the reader's attention. The narrator creates a sort of conversation with the audience and graphically, this is illustrated by using close ups that position him face-to-face with the reader-viewer. The task of the narrator is to guide the reader through the episodes and to show $\mathrm{him} / \mathrm{her}$ the right path to achieve happiness. The intervals between chapters are used to explain the doctrinal points and also, to suggest further readings. In so doing, they become a sort of "advertising break" that interrupts the narration to promote other books published by the group. The frequent 
repetition of the group's logo and name together with the advertising of other publications confirms the importance given to reading and distributing printed material by Kōfuku no Kagaku, for which publishing represents a major source of revenue.

Each episode presents a story with different characters (a young female student, a young boy and a young adult) and contexts (this or "other" worlds), but the chapters follow similar themes and narrative developments. First of all, the protagonist is always represented together with a spiritual guide: an angel, a teacher or shugorei, a "guardian spirit" (except for the last episode, where the young woman herself becomes a guide for her co-workers). The role of the guide, who mirrors the relationship between the narrator and the reader, is to help the protagonist to discover Ōkawa's teachings and to reflect on his/her actions and lifestyle. Thanks to the help of the guide, the central character achieves a sort of "spiritual awakening", and he/she will understand the validity of the leader's teachings and will join the group. Only in the third chapter does the main character, a young man, refuse to admit his mistakes and is damned. The main character in this chapter is the only one who is clearly identifiable with one of the journalists who wrote critical articles of Ōkawa in the magazine Friday (a topic that I will discuss extensively in Chapter Four).

The story stresses the unique, dramatic inner change of the individuals. The focus is on the occurrence of a new, remarkable event through which the character should reflect back and interpret his/her past and previous actions. After joining the group, the protagonist is rewarded with happiness that is expressed through "worldly benefit", such as success in the workplace, improvement in personal relationships and economic success (the idea that economic wealth corresponds to a higher spiritual achievement is a common theme in Kōfuku no Kagaku, Astley 1995; Baffelli 2005).

One can find a similar story pattern, based on an encounter with a spiritual guide, the development of a dramatic event followed by a personal crisis and, finally, a conversion, in other manga published by new religions. For example, in an earlier manga published by Sōka Gakkai, Michore!Taiyō ("Look! The Sun!), which was published in two volumes and illustrated by the mangaka Ishii Isami (born 1941) in 1972-73, the young male protagonist, after the first conversion in volume one, encounters a faith crisis, leaves the group, falls again into unpleasant situation and, finally, understands that he has to return to the group to achieve happiness and/or success. Similarly, Aum Shinrikyō's manga feature stories about the experiences of young people joining the group and, as with Kōfuku no Kagaku, manga were used to advertise other materials and goods distributed by the group (Schodt 1996, 231). The three-volume series Spirit Jump, for example, uses different styles to narrate the history of members who became disillusioned with their lives, joined the group and found happiness through Aum's practice.

The narratives in these manga rely on easy comprehensible schema and reader's identification with the stories' characters (MacWilliams 2000, 10). 


\section{The Importance of Media Engagements}

Although the use of different authors with different styles seems to suggest an attempt to reach different audience groups, the characters in Tengoku no mon (and in the other manga mentioned above) are mainly young employees or students, and their problems concern daily life events (relationships with friends or colleagues, workplace-related stress, low-self esteem). The application of the teachings to daily life encourages the reader's identification, because he/she is probably familiar with the situation narrated in the stories (at the end of Tengoku no mon, the narrator explicitly ask the reader to choose one of the stories in order to understand "the nature of their own soul"). Therefore, the characters' adventures and worries are recognisable to the reader, who can easily imagine being there. Each character embodies a set of values that have to coincide with the values of the group and its leader; otherwise the protagonist will have to face punishment, unhappiness and damnation (such as, for example, the character in the third episode of Tengoku no mon, who refuses to recognise his mistakes and bad actions).

This is only one example of how media texts can be used to present selected and polished conversion narratives in order to both create a model for members and to brand the image of the group for potential new members. In 2006-2007, I conducted research on conversion stories in a small new religion based in Tokyo. I attended the group's meetings in which conversion tales were told and then asked members if they could write down their stories and then, if possible, I interviewed them. Around 50 members answered my questionnaire; 12 accepted a formal interview (that took around 3 hours each), while many others wanted to talk to me informally, during group meetings or while walking in a park in the neighbourhood. Finally, the office staff gave me copies of a group magazine where testimonies about members' first encounters with the group were published. The comparison between different narratives confirmed what other studies have pointed out, that is, "conversion stories" appear to be quite different depending on context. In particular, testimonies in the magazine, as well as written testimonies, appeared very similar and standardised. Almost all members wrote about health problems and the healing benefits received through the group's teachings and practices. The narratives in these stories follow a similar pattern to the manga discussed above: physical sufferanceencounter with the group-happiness. During group meetings, the audience (other members) participates as "authors" and "critics" in constructing the story itself, adding particulars and anecdotes or asking questions. However, in one-to-one interviews, members' accounts became individualised and personal. One of the members I interviewed, who was also employed by the group, realised that the story she was telling me was quite different from her testimony in the magazine (which had a strong focus on health issues and the benefits of the practice). She admitted that she wasn't lying, but that she had adapted her story to the medium, creating a narrative of teaching applied to daily life that could be used as a model by other members. She was, indeed, branding her group as a "healing-focused group". 


\section{IMPORTANCE OF THE NEW: REPACKAGING AND REGENERATION}

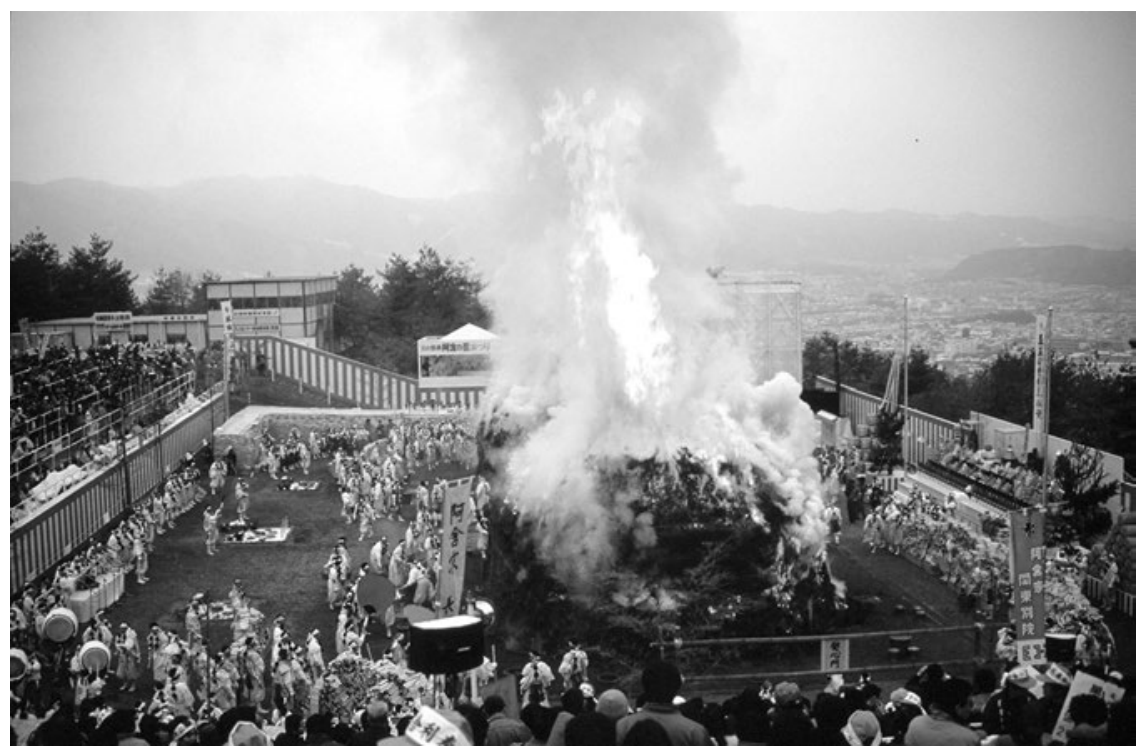

Fig. 2.1 Agonshū Star Festival, 1986/1987. Photo courtesy of Ian Reader. From the Photo Archives of the Nanzan Institute for Religion and Culture, Nagoya, Japan.

As previously discussed, a central issue for the development of new religions is the emphasis on visibility. A new group needs to be visible not only to potentially access a wider audience and to reinforce its proselytism activities, but also to corroborate to members that the leader's message and visions are relevant and that they receive attention from a wider audience. Therefore, the public relations department is an important part of these institutions. To use terminology related to the field of advertising, the emphasis is not only on visibility for the new message and leader, but also on the ability to "brand" this newness.

The concept of shinhatsubai (literally: newly on sale) is often used in Japan as an advertising slogan for the latest and newest products. ${ }^{24}$ However, "new" does not necessarily mean a new product, but can also signify that some new flavours, packaging or functions have been added to an already existing product. The new product is not necessary entirely different from the previous one, but it is innovated and presented as new and updated. In doing this, it offers a way to increase and sustain consumer interest. The notion of shinhatsubai can be used as a descriptive term for Japanese new religions' constant image changes and attempts to be attractive. Often, new religions present themselves as offering a "modern" flavour 
to already existing practices and doctrines, not so much rejecting the existing ones as offering an added and innovative element to them while claiming a new mission. Agonshū, for example, draws on the goma (fire) rituals of the traditional mountain religious tradition of Shugendō (Fig. 2.1), but adds new elements to them such as electronic devices and satellite broadcasting, while also claiming that its form of Buddhism is the "true" and "original” Buddhism (Chapter Three). Kōfuku no Kagaku's advertising campaigns announce that the "Eternal Buddha" is here to bring back a remote golden era from the past. The leader's books are also reprinted in different editions, according to changes in doctrine (Chapter Four), adding some new "flavours" to already existing teachings and doctrines. Jōyū Fumihiro, ex-spokesperson of Aum Shinrikyō and current leader of Hikari no Wa is, along with the members of his group, attempting to survive the trauma that Aum experienced by strongly rejecting the previous leader, Asahara, and Aum's leader-centred group (see Chapter Five in this volume; Baffelli 2012). Through a balancing act in which it retains some of Aum's teachings while discontinuing some of its most problematic practices, such as prophecies and apocalyptic teaching, Hikari no Wa is attempting to rebrand the group to make it acceptable and original.

The sense of movement and process of transformation (Watts 1998, 197) intrinsic in the term shinhatsubai fits the idea of religion as movement (Tweed 2006) and the dynamism of new religions, which are constantly reinventing themselves to be up to date and in order to maintain a process of regeneration so as to make the group continue to appear dynamic rather than mired in the past-a criticism often levelled at established Buddhism in Japan, for example..$^{25}$ Especially at the early stage of their formation, new religions are often pioneers in their approach to media technology and innovative in their image creation. Several image and media strategies may be implemented and the less popular abandoned (similarly, less popular products will disappear from the market shortly after they are launched). Finally, the marketing dynamics related to shinhatsubai highlight the importance of consumers in making a product successful (Watts 1998). Analogously, new religions may change and modify their image strategies according to the needs of members in order to make their messages relevant in changing environments and historical contexts.

\section{VISIBILITY AND ITS RISKS}

Media forms and mediation practices are important for new religions not only for acquiring visibility, but also as source of legitimisation. Undeniably, this aspect is particularly relevant for groups that are still relatively unknown to the larger public and cannot rely on established networks and lineages like older religious institutions. Mass media reporting, however, can lead to criticism, and a group's fate may depend on its reaction to it. Indeed, 
the uses of media technology and visibility in media external to the group are important and necessary, but visibility involves risks, and the potential for religious image improvement described in the previous sections could also prove to be a destabilising factor for some groups. ${ }^{26}$ Several studies have focused mainly on the advantages and potential positive effects of media for new religions in Japan, such as public visibility and recruitment, but the interaction between media and religion spheres is more problematic and ambivalent. ${ }^{27}$ Undeniably, the media has been seen as a factor in the success of new religions, and other groups and organisations have tried to copy their strategies. New religions themselves have been influencing each other in terms of communication and image strategies (see Chapter One in this volume). However, it would be too simplistic to claim that the use of media itself produces success. For example, as considered in Chapter One, visual media supported Oomoto's rapid expansion in Japan. However, in the case of Kōfuku no Kagaku, it is very difficult to determine if the investment in animated movies has attracted new adherents to the group or interest in its teachings (Thomas 2012, 83). Indeed, employing a famous animation studio and using well-known actors as cartoon voices are not enough to create a good film. Furthermore, the focus on moral teachings and doctrinal explanations and the role of the narrator (a guide character or an external voice that guides the viewer and offers him/her a definite explanation of the events) creates a "closed narrative text" ("testo chiuso", Eco 1962) that results in a rather uninteresting and pedantic product, despite its professional technical execution.

Furthermore, as argued in the Introduction, new religions tend to change radically in a short space of time (Astley 2006, 92; Whelan 2007a), especially at the early stage of formation, and they may modify their media strategies, but not necessary in a successful way. Also, media strategies may not be able to keep up with developing media technologies; as mentioned in Chapter One, for example, many new religions have not engaged in new media yet and, as will be discussed in Chapter Three, Agonshü's pioneering approach to media in the 1980s and the success obtained by it has somehow became an obstacle to the development of new media strategies. Finally, other groups have been able to expand without necessarily relying on media so extensively. Numata (1988, 56-86) and Reader (1991, 218-219), for example, have noted that Shinnyoen grew mainly through personal contacts without much advertising, compared to Agonshū. Therefore, the dynamic of membership growth or stagnation in new religions can only be partially ascribed to media use.

New religions need to be legitimised by their presence in the public sphere, but at the same time, they can also very easily delegitimised. A key issue is the control of inputs and outputs. ${ }^{28}$ When using its own media, a group has complete control of how to present itself and how to express itself in the media. Internal media are used for proselytism, but they are often very didactic-oriented products with limited circulation, as they tend to be ignored by general audiences. As a consequence, it is vital for groups to possess their 
own technology to achieve visibility. When employing external companies or media outlets for advertising or other promotional activities, religious groups have a certain degree of control over the final product; nevertheless, as discussed in Chapter Four, negotiations with media outlets, such as newspapers, for example, may be necessary regarding guidelines about what types of images and language are acceptable. The group, however, does not have any control over journalists, media specialists, opponents and, more recently, online users, or on how they comment and report on the group. In all these contexts, neither the media industries nor the religious groups have full control over the effects of their activities, namely how the images and themes portrayed through media forms are received, appropriated and/or rejected by viewers/users. This is an issue that will be discussed further in the Conclusions, where I examine how materials produced for internal use and by internal media can be reappropriated and transformed by users.

As a consequence, new religions could use media forms for advertising campaigns or to promote their activities, but they also could face a backlash through other media. While new religions can control their own media forms and use them to generate support, they are at the same time vulnerable to negative images that are beyond their control, such as critical or defamatory reporting from mass media outlets such as newspapers and magazines, journalists and, increasingly, from online sources. This is an issue I raised in Chapter One and it remains a crucial issue in how new religions function and operate. The intense use of mass media and marketing by new religions has been a controversial topic. On the one hand, stories about members being asked to donate large sum of money or about wealthy religious leaders are recurrent topics in reporting about these groups. Prurient stories about religious leaders or scandals related to new religions can potentially increase media circulation (Dorman 2012a) and rivalry between groups has been fueled by media accounts (Baffelli and Reader 2011). Testimonies from ex-members are often reported in weekly magazines or published as books to criticise the group practices or to denounce allegedly suspicious practices in propagation strategies. For example, an ex-member of Agonshū published a book on the group claiming that members would go to bookstores to buy several books by the leader to show that the books are popular and can potentially sell a lot of copies (Hirono 1992, 28). Furthermore, the above-mentioned spectacular events, while enhancing prestige and visibility, could also have negative effects in the wider context. Sōka Gakkai mass performances, for example, with their staged presentations of thousands of disciples in unison, were seen by some viewers as similar to military parades and even provoked images of fear, as in the very negative description of a Sōka Gakkai event by McFarland:

Almost frightened by the possible implications of these manifestations of mass energy and blind obedience. For one who remembers the World War II period, such a spectacle had a haunting effect. His [sic] mind 
flashes back to newsreel dips of Nazi youth rallies and other similar vignettes of the totalitarism that once nearly destroyed civilization. Is the similarity here more circumstantial? Is this fascism reborn?

In this context, a key issue is how religious groups respond to criticism and hostility. Some movements have adopted a strategy of not replying to media criticism or of not reacting in a hostile way, while others have openly contested them. For some groups, a direct confrontation with the media resulted in loss of credibility and, in the case of Renmonkyō discussed in Chapter One, the group did not survive the backslash. Different responses resulted in significantly different outcomes for the group, impacting on its image and survival. Dorman's work Celebrity Gods: New Religions, Media, and Authority in Occupied Japan, for example, investigates how two Japanese new religions, Tenshō Kōtai Jingūkyō ${ }^{29}$ and Jiu, ${ }^{30}$ reacted to substantial press attention and harsh criticism from the print media. Dorman's study shows how the two groups' reactions had a significant different impact on the groups' future. Kitamura, the leader of Tenshō Kōtai Jingūkyō, attempted to turn media harsh criticism to her advantage, and the group managed to grow. By contrast, in the case of Jiu, the negative press, combined with police intervention and the arrest of key members, resulted in high-profile members leaving the group and Jiu disappearing from the public eye.

A different attitude was showed by the Buddhist group Risshō Kōseikai, which in the 1950s was the object of a series of critical articles published by the newspaper Yomiuri Shinbun. Critical accounts about discontented ex-members had already appeared on public television in 1952 (Morioka 1994) and in 1956, the newspaper launched its derogatory campaign that led to the so-called Yomiuri Affair (Yomiuri jiken). The group's reaction was restrained and no legal action was launched against the newspaper. According to Morioka's analysis (1994), Risshō Kōseikai was able to use the affair as an opportunity to restructure its doctrines and organisational structure, thereby providing the basis for the development of a larger movement, while the newspaper suffered a drop in circulation as many Risshō Kōseikai members discontinued their subscriptions.

Sōka Gakkai has been possibly the most criticised organisation in the Japanese press. In the postwar period, its rapid growth, members' commitments and fervent proselytism activities attracted public attention and concern. In 1969-1970, the group was accused of attempting to stop the publication of a critical book, Sōka Gakkai o kiru ("I Denounce Sōka Gakkai"), by Fujiwara Hirotatsu. This event, which is known as the Obstruction of Press Freedom Incident (Genron Shuppan Bōgai Jiken) generated a series of unfavourable reports in weekly tabloids and the formation of a genre that McLaughlin has defined as "anti-Sōka Gakkai journalism" $(2009,97)$, that is, frequent attacks by the press (in particular, weekly magazines and tabloids, more rarely, newspapers) on the group, including salacious stories 
and scandals involving the leader, gossip about members who are part of the celebrity business and conjectures related to the role of Kōmeitō, ${ }^{31}$ the political party previously affiliated with Sōka Gakkai.

When responding to media vilification, some groups have embarked on moralising campaigns about the role of media in modern society, and accused the mass media of being evil and corrupt. In this way, some movements seem to take a very incoherent attitude toward media, seeing them as necessary and proper when used to support the group's agenda, but at the same time as corrupted and wrongful when criticising groups' teachings and practices. Kōfuku no Kagaku, for example, as will be extensively discussed in Chapter Four, attacked external media through its own publications (for example, a chapter of Ōkawa's book, Arā no daikeikoku, "Allah's Great Warning", is entitled "The Crimes of Mass Media”, Masukomi no hanzai, Ōkawa 1991) while at the same time claiming that religion should use technology when it is useful for its own purposes (Ōkawa 2001). In the 1990s, Kōfuku no Kagaku reacted to media criticism in a confrontational way, attacking a publisher's offices and promoting a moralising campaign against the mass media (see Chapter Four in this volume) and this allowed the group to limit, albeit not completely, the damage caused by the criticism it faced. Similarly, Aum Shinrikyō responded to condemnatory accounts published by the weekly magazine Sunday Mainichi in 1989 by filing lawsuits against the magazine (Reader 2000a, 148). In the early 1990s, however, Aum often replied to criticisms by promoting its image through the mass media and increasing its presence on television talk shows and in public events (Reader 2000a, 173-175), ${ }^{32}$ therefore using criticism as a chance for self-promotion, while at the same time attacking ${ }^{33}$ and ridiculing journalists, magazines and newspapers that criticised the group and its leader.

As the case studies discussed in the following chapters will show, new religions have also attempted to limit the risks by controlling access to the media. For example, although magazines and books published by new religions can generally be bought by non-members, access to videos and DVDs is often more restricted. In the case of "news videos", for example, or in case of Agonshü's videos about rituals, they could only be seen at the movement's centres or in a controlled environment (that is, with a representative from the group present). ${ }^{34}$ The issue of control is becoming more pressing and more challenging with the rise and continuing expansion of the Internet. In particular, social media makes it more difficult for groups to control even their own media, as members can have access to the platform and can take the initiative in presenting the group online. ${ }^{35}$ Even in the case of Hikari no Wa, which uses the Internet as its main platform for presenting videos and other material, the access to material is controlled. As discussed in other publications (Baffelli 2011 and 2012), for example, a section for members only has been created on its official website and comments on videos are not allowed in video sharing websites such as YouTube. Therefore, as these examples illustrate, in order to use media effectively, new religions 
are required to invest in sophisticated image strategies that could also counterbalance the potential risks.

The themes described in this chapter illustrate the dual-edged sword represented by media engagement and mediation practices. Indeed, control of media technologies and mass-media visibility legitimate and validate new religions, offering opportunities to proselytise widely and increase interest, to develop and to brand the image of the leader, to draw large numbers of people to be part of their events and also to enable them to participate in mass ceremonies in an intimate way. At the same time, however, overexposure in the mass media and excessive ostentations of opulence may have a destabilising effect on new religions by providing an avenue for criticism and hostility (such as derogatory reporting, scandals and mass-media defamatory campaigns) and enabling people outside the movement to scrutinise and criticise the movement's teachings and practices that may be perceived as unusual and against social norms. As a consequence, new religions' attitudes towards media industries and media technologies tend to be ambivalent; media are useful and powerful devices for enabling new religions to enter public discourse and be taken seriously, but at the same time, movements need to protect themselves and their leaders from outside scrutiny in order to preserve their cohesion and their legitimacy.

\section{NOTES}

1. For a detailed history of Seikyō Shinbun, see McLaughlin 2009.

2. This aspect is clearly illustrated in Mori's documentary A, in which Araki, Aum's new spokesperson, and other members are overwhelmed by requests from the press and TV programmes and, at the same time, their explanations about the events seem contradictory and confused.

3. In another advertising text published in the magazine Shükan Sunday (July 9, 1987, 232-233) Agonshū's use of new media, in a particular satellite broadcasting, is emphasised.

4. On various occasions during visits to their centres in 2005-2006, I was shown a video narrating the history of the group via the implementation of different media. In October 2006, I accompanied a group of undergraduate students on a visit to the branch in the city of Tokushima (Shikoku Island) and the video was shown at the beginning of the meeting, preceding a brief explanation about the movement's main doctrinal aspects. Interestingly, the group's successful engagement with media practices was considered more relevant than its doctrines when presenting itself to the general public.

5. On shinsōkan, see Staemmler 2011, 158-59.

6. Offner and Van Straelen also describe the use of media-related metaphors in Seichō no Ie: "Frequently in Seichō no Ie writing the phenomenal world is described as the images cast upon the screen when a film, blocking the perfect flow of light, is placed in a projector. As the film is changed, so the images cast upon the screen of life change accordingly. By a recognition of the true nature of reality, the film is changed and the light of the real world disperses the shadows of the world of illusion" $(1963,128)$.

7. According to Whelan (2007a), the metaphor is no longer used in the GLA. 
8. Several works have discussed the role of charismatic leadership or focused on specific new religions' founders in the Japanese context. Just to name a few, Baffelli (2005); Chilson (2014); Kawamura (1981); McLaughlin (2009); Numata (1987 and 1988); Ooms (1993); Reader (1991); Shūkyō Shakaigaku Kenkyūkai (1987); Staemmler and Dehn (2011); Stalker (2008). Charismatic leadership has also been discussed in many works on new religious movements in other contexts. For example, for a discussion on the redefinition of charisma in China, see the Special Issue of Nova Religio 12, 2 (2008), edited by Vincent Goosaert and David Ownby and including articles by Julia Huang, Ji Zhe, David Palmer and Stephan Feuchtwang. See also Palmer (2007). For a general overview of charismatic leadership in new religious movements, see Wessinger (2012).

9. This issue is one that requires a separate discussion and is beyond the scope of the book, but various new religions have had problems with dealing with the transition from an initial leader to later leaders (see, for example, Whelan $2007 \mathrm{a}$ on the transition of leadership in the GLA).

10. Interview with a representative of Sōka Gakkai Academic Affairs Division, May 2012.

11. In his PhD dissertation, McLaughlin reports several occasions in which members gathered together to watch satellite broadcasts.

12. McLaughlin reports a member's declaration that broadcasts are "when Ikeda's sincerity (shinkensa) is transmitted" (McLaughlin 2009, 305).

13. Other videos are used for big events and educational purposes (DVDs, for example, are used to support group discussions), and they are usually in lecture style. Short lectures are also available on the website and are designed to support seminars and lectures and to help the local leaders in preparing the monthly meeting. Interestingly, since Ikeda stopped attending the representative meeting in 2010, the group has been introducing more TV-style techniques (including music performances and dances) in the broadcasts to replace some of the speeches in order to increase the entertainment aspects now that the main attraction of the videos (that is, Ikeda himself) is absent.

14. According to the group's' representative (personal communication May 2012), Sōka Gakkai is now considering gradually shifting from broadcasting to the Internet because of the high costs associated with the receiving equipment, which needs to be replaced every few years, and which are especially onerous for smaller centres.

15. For example, videos of the founder Itō Shinjō (1906-1984) and his wife Tomoji (1912-1967) were used in Shinnyoen ceremonies. Thank you to Monika Schrimpf for this observation.

16. In a book chapter on religious fundamentalism, Davis describes the Grand Festival of a new religion in Tokyo. The group is called by the pseudonym "Church of Health and Happiness" and the account of the grandiose event (expectant members, grandiose music, solemn entrance of the leader, presentation of testimonies, touched and thrilled members, pompous leader and so on) recall similar reporting of new religions' events from the postwar period to the 1990s (1991,782-83).

17. See also Inoue et al. (1994).

18. See, for example, the catalogues with collections of festival images accompanied by explanations of the dances and of the various stages of the ceremony '67 Tōkyō Bunkasai Kiroku Iinkai ed. (1982); Kita Heiwa Bunkasai Shashinshū Hensan Iinkai ed. (1985). In addition, see the videos recorded during the festivals, such as Heiwa no Michi, Bunka no Michi, Sekai no Michi (1990), a video of the celebration of the 60th anniversary of the foundation of the Gakkai held on November 18, 1990 at the Yokohama Arena in Yokohama. 
19. Mass performances organised by the group were also performed around the world. In 1994, for example, the spectacle Ali was held at the Teatro Lirico in Milan, and volunteer artists from throughout Italy participated in the production.

20. Some of the main events of the group are the Hoshi Matsuri, which is held in Yamashina, in the Kyōto area, on February 11th, and a fire rite, known as Tsuitachi Goma, which takes place at the Tōkyō branch on the first day of every month.

21. The event was reported in similar terms in several magazine articles. See, for example, Arita (1991); Egawa (1991a) Friday 30, July 26, 1991; Friday 31, August 2, 1991.

22. For a detailed account on "spiritual dialogues", see Whelan 2007a, 133.

23. The authors are Saito Eiichi (prologue and intervals), Isobe Mamoru (chapter 1), Nanbara Ban (chapter 2), Kikuike Toshiwo (chapter 3) and Ōishi Nozomi (chapter 4).

24. Kornicki $(1994,183)$ indicates that the concept was used as part of advertising rhetoric for the book trade well before the Meiji Restoration. A search on Kikuzo II Visual, a database of the Asahi newspaper, showed that the term was used in the Meiji period in advertising (see, for example, Asabi Shinbun March 13, 1880, Osaka edition).

25. For recent works on Buddhism in contemporary Japan and its perception, see Covell (2005); Reader (2011); Rowe (2011).

26. It also worth mentioning that being involved in communication strategies for new religions may involve risks for companies as well. In the $1980 \mathrm{~s}$, for example, Dentsū was initially reluctant to work with Agonshū. Also, as discussed in Chapter One, alternative voices, such as Mori's documentaries, in presenting new religions may face social ostracism.

27. Some studies have indeed indicated some ambivalence in the relationship between media and new religions in Japan. See, for example, Baffelli, Reader and Staemmler (2011); Dorman (2005a; 2012a); Dorman and Reader (2007); Reader (2000).

28. I am grateful to an anonymous reviewer for his/her input on this discussion.

29. See note 36 in Chapter One.

30. Jiu was a small new religion founded in the early 1940s by Jikōson (born Nagaoka Nagako, 1903-1984). See Dorman 2012a.

31. For an up-to-date work on Kōmeitō, see Ehrhardt et al. (2014). On religions and politics in postwar Japan, see also Nakano (2003); Tsukada (2015).

32. For detailed data on the media used by Aum and reporting about the group, see Inoue and RIRC eds. (2012).

33. Aum members also attempted to murder Egawa Shōko, the journalist who published several critical articles about the group (Egawa 1991a).

34. For example, it was reported to me that permission to show an video by one of the religious organizations mentioned in this chapter during a lecture in a university in Europe was granted on the condition of a representative of the group being present at the screening.

35. In several interviews with Kōfuku no Kagakus representatives it was reiterated that access to some videos was restricted (members can only watch them at the centres). Kōfuku no Kagaku tended to have a centralised approach to media produced by the group, but recently it has allowed some individual initiatives. In 2008, for example the head minister at the Happy Science Centre in Auckland established a radio programme in English streamed online (Happy Science on Air, now discontinued), and in 2014, an independent radio programme by Kōfuku no Kagaku members started on a radio station in Miyazaki (personal communication with representative at Miyazaki branch, July 2014). 


\section{Mediating (Buddhist) Rituals Agonshū's Satellite Broadcasting}

Agonshū, a group that developed in the late 1970s from a previous organisation founded in the 1950s, gained public and media attention in the 1980s and early 1990s due to its aggressive use of media and for its widely advertised public event, the Hoshi Matsuri (Star Festival) (Iwasa 1993, 130).

As was discussed in Chapter One, the intensive use of mass media to advertise teachings and events was nothing new for Japanese new religions. Furthermore, during the same period, other Buddhist groups were experimenting with the introduction of new technologies into traditional rituals in order to create attractive and spectacular events (see the examples described in Reader 1994, 40). For example, Oohashi (1988) discusses a series of experiments carried out during Expo' 85 by a team of researchers at Tsukuba University related to a digital system, INS, developed by NTT (Nippon Telegraph and Telephone Corporation, Japan's largest telecommunications company), which featured an optical fibre network with a satellite system. One of the organisations that participated in the experiments was the Kongōbuji Temple, head temple of the esoteric Shingon Buddhist sect. On June 8 and 9, 1985, an esoteric ritual was performed at the temple in Koyyasan (Wakayama Prefecture) and transmitted to a hall in Tsukuba, near Tokyo. The priest explained the ritual to the audience and the script of the mantra to be chanted was sent by facsimile to the participants (Oohashi 1988, 96). According to Oohashi's account, the viewers became progressively involved in the rituals and started participating in it from a distance:

As the programme proceeded, the audience was able to follow the ritual at Koyasan on the screen. The spectators could also look at the script of the tantric chant which was being transmitted by facsimile. Some of them were involved in the chanting, and, incredible as it may sound, most of the spectators inside the hall finally joined in the incantation. [...] Gradually, the entire hall was transformed into a meditation space connected on-line with Koyasan. The audience prayed and chanted, and their voices filled the hall with a resounding chorus [...].

(Oohashi 1988, 96) 
Agonshū, one of the first organisations to use satellite broadcasts and considered one of the most technology-conscious religious groups in Japan (Reader 1991, 218), understood the possibility offered by new technologies to enhance viewers' experience of a religious ritual. Its use of media technologies and visual culture, from large advertising campaigns to spectacular rituals transmitted via satellite broadcasting, has been pioneering and has influenced other groups' use of media (for example, Kōfuku no Kagaku, discussed in Chapter Four in this volume).

Agonshū not only has used media to construct its public image and to spread its teaching, but it has also been innovative in developing business relationships with communication and marketing agencies, employing, for example, external experts on advertising and image management. As I will discuss later in this chapter, the promotion of religious practices through mass media (books, videos, billboards, radio and so on) together with the ability to package traditional practices, such as esoteric Buddhist fire rituals or Shugendō training, in modern garb-transforming the rites into "saleable, consumable products" (Grimes 2006,15) that can be "experienced" through the screen and repeated infinitely via DVDs—are the keys to understanding Agonshü's success in the 1980s. Furthermore, this analysis shows how mediation practices can create new forms of religious practice or affect existing ones, and how the technology was used not only to create spectacular ritual events, but also to engage members in the ritual from a distance, allowing them to recreate the community dimension of the ritual through the screen.

My descriptions of the rituals in these chapters are based on attendance at the Hoshi Matsuri in February 2006 at Agonshū's main temple in Kyoto and regular attendance at events at its main centre in Tokyo: First of the Month Fire Rite (Tsuitachi engi hōshō goma, attended regularly at the Tokyo centre between December 2005 and June 2006 and in February 2007) and the Ritual for the Liberation of the Spirit of Ancestors (meitokusai, May 2006, June 2006, January 2007, May 2012, all at the centre in Tokyo). In addition, I attended the transmission of the goma rite performed by Kiriyama, Agonshü's leader, in Auschwitz (Poland) on June 13, 2006, and the New Year's Sacred Fire Ceremony (Hatsugoma, January 2009, January 2014), both at the Agonshū centre in Tokyo, and followed Agonshū's One Peace Live Aura Festival that was streamed live on the Internet on November 7, 2010. In July and August 2014, I attended the Mandō senzo kuyō, the annual lantern memorial ceremony for the ancestors, in Tokyo and the First of the Month Fire Rite transmitted via satellite at the Miyazaki centre in Miyazaki city. In addition, I have interviewed members attending the rituals at the Tokyo centre, a former public relation representative who was in charge of Agonshū's public image, advertising and media in the early 1980s and representatives of the Tokyo headquarters.

The focus of this chapter is on the use of satellite broadcasting by Agonshū, but before introducing the different ways in which Agonshū transmits rituals, a brief overview of the group and its teachings is necessary. 


\section{KIRIYAMA SEIYŪ AND THE “ORIGINAL BUDDHISM”}

As with other new religions, Agonshū focuses on a charismatic leader and its cosmology, drawing mainly from esoteric Buddhism and Shugendō, ${ }^{1}$ and is based on what Reader and Tanabe (1998) have defined the "common religion of Japan", that is the pursuit of genze riyaku (practical benefits). Kiriyama Seiyū, the founder of Agonshū, was born in 1921 as Tsutsumi Masao. His life before becoming a religious leader was marked by a childhood of poverty and several business failures, culminating in a sentence of six months in prison for tax offences in 1953. According to Kiriyama's own account, his religious search began when he read, after a suicide attempt, a copy of a text (the Kannonkyō) in praise of the bodhisattva Kannon and started believing that he had been saved by Kannon. In 1954, Kiriyama founded a group called Kannon Jikeikai (Kannon worshipping movement) and in 1955, he obtained a lay ordination in the esoteric Buddhist school Shingon and changed his name: ${ }^{2}$

By undergoing a long period of ascetic practice, standing under waterfalls, meditating, fasting, reciting Buddhist prayers and making offerings to Kannon, he came to realize that he had been surrounded by karmic hindrances (specifically, unhappy ancestral figures) that were the root cause of his failures. His religious practice served to eradicate these hindrances and, at the same time, to build up a small group of followers. In 1970 Kannon appeared to him in a dream and told him he had eradicated the encumbrances of the past (in Agonshū terminology he had 'cut his karma'-karuma o kiru): henceforth he was no longer a seeker but a guide for others and was to go out and help others 'cut their karma' and find salvation.

(Reader 1991, 209-210)

In 1971, Kiriyama published his first book, Henshin no genre ("The Principles of Transformation") and became a prolific writer, ${ }^{3}$ but by 1974 , the group still only had a limited number of members (500, according to Prohl (2004, 463); see also Bunkachō (1977)). In 1978, Kiriyama changed the name of the group to Agonshū and introduced the reading of the Āgama sutras (in Japanese, Agonkyō), early pre-Mahayana Buddhist texts. Kiriyama claims that Agonshū's teachings represent the "original Buddhism" (konpon bukkyō or genshi bukkyō, Kiriyama 2001, 2); his teachings are based on his interpretation of the teaching of the Âgama sutras. Kiriyama used his personal life experiences to claim that he had discovered the "hidden truths" in the Āgama sutras and that unhappy spirits-who are suffering because they weren't able to achieve liberation after death-are the causes of human beings' problems and misfortunes. Kiriyama asserts that his method can free people from the negative influence of "wandering spirits" (reishō) and will bring happiness and good fortune; accounts from his personal history are 
often used in his writings and talks in order to demonstrate the role played by malignant ancestral spirits in his misfortune, and his ability to overcome difficulties and to became the role model for his method.

Agonshū's practice focuses on three esoteric methods of training (shugyō): jōbutsu hō (the Dharma of attaining Buddhahood), a method to "cut one's karma", that is, to be freed of the spiritual hindrances that, according to Agonshū's teaching, influence individuals' well-being, fortune and destiny; the Dharma of the Wish-Fulfilling Jewel (nyoi hōju hō), a practice performed with the shinsei busshari, a miniature representation of the relic of the Buddha, donated to Agonshū in 1986 by President Jayewardene of Sri Lanka and believed to have the power to transform the spirits of the dead and fulfil the wishes of the living (Reader 1991, 217), in order "to gain happiness and good fortune" (Agonshū 1989 quoted in Prohl 2004, 463-464); and the Buddha's Dharma (gumonji sōmei hō), an esoteric doctrine developed from kundalini yoga and Taoism that is said to be able to "make a person a genius". ${ }^{4}$ As with most Japanese new religions, Agonshū does not demand absolute adherence from its followers.

Rituals are performed in Agonshū for two main aims: to realise the wishes of living people and to liberate the souls of dead ancestors. The event calendar includes major rituals (performed monthly or annually, such as the First of the Month Fire Rite held on the first day of each month or the Hoshi Matsuri in February) and some occasional events, such as the performance of fire rituals overseas. According to Agonshū, the ceremonies performed outside Japan are "dedicated to world peace and harmony", 5 and they are usually held in places where tragedies and large numbers of death have occurred in dramatic circumstances (for example, on October 2009, a Fire Rite ceremony was organised in Guadalcanal to commemorate the war dead in the South Pacific). These rituals are aimed at pacifying and bringing peace to spirits that have not been properly memorialised and therefore are unhappy and potentially a source of unease. On other occasions, events are organised in major centres to attract attention and position Agonshū as a group connected with other world religions (for example, in September 2008, a Fire Rite ceremony was held in Jerusalem on the occasion of the 60th anniversary of the founding of Israel).

The number of Agonshū's members increased exponentially in the 1980s. The number of members declared by the group rose from just over 30,000 in 1980 to over 200,000 in $1984,{ }^{6}$ and over the years, new centres were established in Taiwan, Brazil, California and the United Kingdom. In an article published in the Kyoto Shinbun on October 2, 1993, the rapid increase in the number of participants during the Hoshi Matsuri in 1984, according to the article, 40,000 more visitors attended the event compared to 1983. This was attributed to the group's media and event strategies, including TV and radio advertising and PR events. Although the above figures may have been inflated, it is clear that Kiriyama was able to connect to growing numbers of followers in the mid-1980s by using his own experiences, introducing 
mainly worship-related practices with an esoteric flavour that made them look exotic, by suggesting that people could access spiritual power and by intensifying efforts of media usage and public events.

\section{AGONSHŪ AND THE MEDIA: THE CONSTRUCTION OF A RELIGIOUS GROUP'S IMAGE BY A “MEDIA MIX” STRATEGY}

Agonshū's media and image strategies in 1980s were planned by its Public Relations Department, focusing on what it is often called in Japanese media mikkusu (media mix), that is, the combination of multiple media types for the promotion of a product (such as a movie). As with many new religions, the first step was to establish a publishing house, called Hirakawa Shuppan. Agonshū's aim, however, was not simply to distribute the leader's books through internal channels-such as selling the books at group centres or asking members to distribute them-but also to reach general bookstores and to transform them into "showcases for the group". ${ }^{7}$ Agonshū also hired Dentsū Corporation, the largest advertising company in Japan, to implement its image strategy. According to a former PR representative of Agonshū, it was quite arduous to persuade Dentsū to work for it, because of the company's concerns with being associated with a religious group,${ }^{8}$ but Agonshū's success in getting a large advertising agency to work for it opened the doors to future collaborations between advertising agencies and new religions in Japan-a path later followed by Kōfuku no Kagaku (see Chapter Four in this volume). In the following years, Agonshū also collaborated with various professional artists and experts, such as, for example, the manga writer Iida Kōichirō for the manga series in three volumes, Mikkyō no nenriki "Power of Esoteric Buddhism", 1988-89). ${ }^{9}$

The advertising concept was developed by the creative staff of Dentsū, but because of their inexperience with religious organisations, Agonshū's general manager in its Public Relations Department and his staff had a crucial role in selecting the texts (both written and visual) and in the design of the campaign. The advertising campaign received final approval from Agonshū's leader (Kyoto Shinbun, October 21, 1993). ${ }^{10}$ The first aim of the advertising campaign, which was based on market research and modified accordingly, was to make the name of Agonshū clearly visible and recognisable to the general public. The mass media campaign had the scope to create interest in the group's activities and events, and eventually to attract potential new members. The advertising campaign covered major newspapers and magazines ${ }^{11}$-at times, the text occupied more than one entire page-and also appeared on posters in train stations. It was centred on the leader's image, his publications and the group's events, and aimed to promote the idea of an up-to-date and technology-savvy religion. For example, in the title of one of advertising pages published in the magazine Shükan Sunday, Agonshū defined itself as "the religion of the new media age" (nyümedia jidai no shükȳ̄) 
and announced that it was covering seven big Japanese cities with its satellite broadcasting, while comparing its activities to American televangelists (Shükan Sunday, July 9, 1987, 232). In another advertisement, in English that appeared in the Mainichi Daily News on October 15, 1987, Agonshū is promoted as "The Original Buddhism for a Modern World", branding the image of a contemporary religion rooted in traditional Buddhism.

Agonshū, like other new religions at an early stage of their formation, experimented with different media and communication strategies. The publishing house distributed the leader's books, and various magazines were also established, such as Agama in 1979 (now discontinued). Some of the publications used initially were lately discontinued, such as the magazine Seika ("Sacred Fire"), published between 1976 and 1983 and devoted to the Hoshi Matsuri, with pictures and explanations of the ritual. At the same time, the group started using television and radio broadcasts, as well as shortwave and satellite broadcasting. The organisation didn't decide on a step-by-step strategy. Rather, it worked simultaneously on different media projects as circumstances dictated. Agonshū also produced numerous videos and films that expounded the leader's messages, and installed video display systems at all their centres so that any member or visitor could watch them. In addition, its media usage was reinforced by the development of PR activities, such as religious festivals or events aimed at sponsoring interfaith dialogues on world peace (for example, a meeting with the Dalai Lama in 1984 and with Pope John Paul II in 1985), in order to create what Matsuzawa Masahiro, former head of Agonshū's Public Relations Department and former editor-in-chief of Ägama, termed "eventification" (shükyō no ibentoka, Matsuzawa 1985, 73). Therefore, Agonshū consciously implemented a strategy to promote its image and activities to a larger public, and Kiriyama used examples of media-savvy religious groups, such as American televangelists, as a model for his own use of broadcast media (Whelan 2007a, 404).

\section{Satellite Broadcasting}

Agonshū was not only one of the first religious groups to use satellite communications, it was one of the first private organisations of any kind to engage in live satellite broadcasting in Japan. ${ }^{12}$ In the early 1980 s, some telecommunications companies were introducing satellite communications in Japan and contacted Agonshū, amongst other companies and organisations, offering a free trial of the new technology. For Agonshū and its Public Relations Department, this sounded an interesting opportunity and they decided to accept the proposal. The group waited for an appropriate occasion, and the inauguration of the Kantō region centre in April 1987 was considered the right event for testing the transmission. Agonshü's first broadcast was transmitted on April 8, 1987. The group borrowed equipment from the NTT for this purpose and transmitted the broadcast 
to centres in Kyūshū and Hokkaidō. Afterwards, from May 1987, it was decided to perform a fire rite on the first day of each month and to transmit it by satellite. The rite was initially performed in Tokyo and transmitted in Kyoto and later to other centres. ${ }^{13}$ At that time, the group rented half an hour of transmission time and the rite was created to take exactly 30 minutes (Reader 1991, 226). The tsuitachi goma is a traditional fire rite performed by esoteric Buddhism sects, but in Agonshū's ritual, the presence of the media is not only important, it plays a central role. Indeed, the ritual was not just supported by and transmitted through the media, but was especially modified and recreated to fit the new technology. During the last thirty years, Agonshū has developed the use of satellite broadcasting, and nowadays, two types of events are usually screened: indoor rituals, namely the monthly tsuitachi goma and the meitokusai, a ritual for the ancestors, transmitted respectively from Agonshü's Tokyo and Yamashima centres; and outdoor rituals, namely the annual Hoshi Matsuri and some occasional goma rites performed by the leader overseas. In these events, the use of satellite broadcasting and how viewers interact with it present some crucial differences that I will analyse in more detail in the following sections.

\section{INDOOR RITUALS ON-SCREEN: CREATING A NATIONWIDE VIRTUAL TEMPLE}

As mentioned before, two main indoor rituals started to be performed in the late 1980s by Agonshū: tsuitachi engi hōshō goma (a fire rite), held on the first day of each month at the Tokyo centre, and meitokusai (a rite for the ancestors), performed on the 16th of each month at the Yamashina temple in Kyoto. Both rituals are transmitted to other Agonshū centres throughout Japan, where members assemble in front of large video screens and participate in the rite being performed on the other side of the country. The transmission, which is aired by the Agon New System Network (Agon Nettowāku Shin Shisutemu), usually starts before the ceremony with images from outside the temple, showing attendees being welcomed by members at the entrance. Sometimes, the audience is entertained while waiting with videos showing an orchestra playing Agonshū-related songs or advertising for the group's new publications. Then, as a sign that the ceremony will be starting shortly, the voice of a presenter welcomes participants who are taking part by satellite broadcasting, inviting them to pray and explaining the aims of the ritual (in the case of the tsuitachi goma, these are the world peace, good fortune and improving the participant's luck, while the meitokusai focuses on praying for ancestors' souls). The same speaker will say goodbye to the participants at the end of the transmission. Both rituals include two parts: a fire ritual performed by Kiriyama and a brief speech by the leader himself 
(but only the first part of his speech, around 10 minutes, is transmitted to all centres, although often he talks for longer). ${ }^{14}$ When I participated in the event at the Tokyo centre, the regular monthly audience numbered between 250 and 400 people. Non-members were clearly identifiable by a "guest" nametag, but they were usually in a minority. Three TV sets were installed on the first floor, and two big screens and five televisions were placed in the main hall on the second floor.

In the transmission of indoor rituals, the camera is placed at the same vantage point as a participant attending the rite in person and sitting in the best seat in the temple hall. The camera faces an altar or some other focus of the ritual, which is often Kiriyama or an Agonshū priest leading a prayer or chant. There is no panning, no zooming, no fading to another scene, except for a few brief static images of the busshari (sacred relic) after the fire has been lit. The camera image is static and unchanging, as if the person viewing the ritual through the screen is right there at the same physical location. The camera follows, rather than drives, the action.

When I attended the rituals, the members watching the video through the screen responded to the leader's questions and chanted the sutras in very much the same way as those attending the live performance. The ritual seemed to be "extended by the media" (Grimes 2002, 220) and "made present" (Grimes 2002, 221) through the screen. The members "participate" in the ritual, even though they do so at a distance, and are actively involved. Furthermore, even when the ritual is performed live, the screens in the hall are turned on and they show how the ritual is being transmitted and what the members in the other centres are watching. The framing is the same for both the Tokyo and Kyoto centres (the altar with the sacred relic is moved from one centre to the other before the ritual), and this creates the impression to viewers that the ritual is indeed performed always in the same location.

During an interview with a former representative of the Public Relations Department, he argued that the synchronism of satellite communications created a "sense of unity" and a "feeling of solidarity" between viewers. For the members, he added, it is usually difficult to understand what the leader is doing during the ritual because he is too distant and the sacred relics are often closed in an inner altar and are difficult to see. Via satellite television, every member has a good position-that is, the position of the camera-and can clearly understand the founder's speech. Therefore, the camera helps viewers to grasp the actions and make all members equal (they are all virtually seating in the best seat inside the temple hall). Furthermore, they can participate along with the leader in events in Kyoto or Tokyo without having to travel:

Even if the place is distant it is wonderful the feeling of sharing the same prayer and the same feelings. In the traditional pilgrimage the sense of 
unity comes from being in the same place, even if at different time. With the satellite communications the reverse is true: being in a different place at the same time. ${ }^{15}$

This idea of connection through the technology is also repeated in the advertising material used to promote the broadcasts. For example, the above-mentioned advertisement in the Mainichi Daily News in 1987 says, "Agon-shu is the first religion in Japan to use satellite broadcastings of services to link their believers around the country" (p. 5). Viewers put themselves in a position to engage in the screened performance by first ritualising their own view. They arrive at the temple before the start of the ritual, receive the information material at the entrance, buy the wooden sticks (gomagi) on which prayer and requests are made, write their wishes/prayer, enter the main hall, get their rosaries ready and wait quietly until the beginning of the ritual. The effectiveness of the screened ritual, as described by group's representatives and participants, is enhanced by viewers' active participation in the performance. This modifies the conventional understanding of ritual as face-to-face, to include viewers at the group's centres as participants in the broadcasted performances.

In a study on American televangelism, Alexander argues that the potential of televangelism to promote community is undermined by the medium itself, television, which does not permit direct interaction between viewers: "Here community is not direct or immediate and spontaneous, as in the case of the usual, face-to-face forms of rituals that embody community" (Alexander 2007, 205). Similarly, in the case of Agonshū, the message is unidirectional and there is no interaction between the leader and the viewers via the screen. However, viewers gather in the same place to watch the ritual and they can continue discussions about it afterwards, share their opinions, ask for more information and engage in ritualised activities (for example, buying wooden sticks for the rituals, eating together the rice balls received before the ceremony and so on). The viewing is not a solitary, atomised experience, as is watching a ceremony on television alone at home, and the satellite broadcasting allows for a transformation and enlargement of the traditional temple space to include all Agonshü's centres in Japan. The performance of the ritual via the means of the screen involves the collective body of members in a specific physical space (the sacred place), and the role of ritual is to unify the practice and create a collective identity as part of a (virtual) nationwide temple. Therefore, the televised experience of the ritual watched with others is both collective and individual(ised) at the same time. Participants can see it in a very personal way, but also feel a sense of communal participation.

This analysis, however, seems to apply only to indoor rituals, attended mainly by members, so I will now turn my attention to outdoor public rituals. 


\section{OUTDOOR RITUAL SCREENINGS: EXPERIENCING A SENSE OF "BEING THERE”}

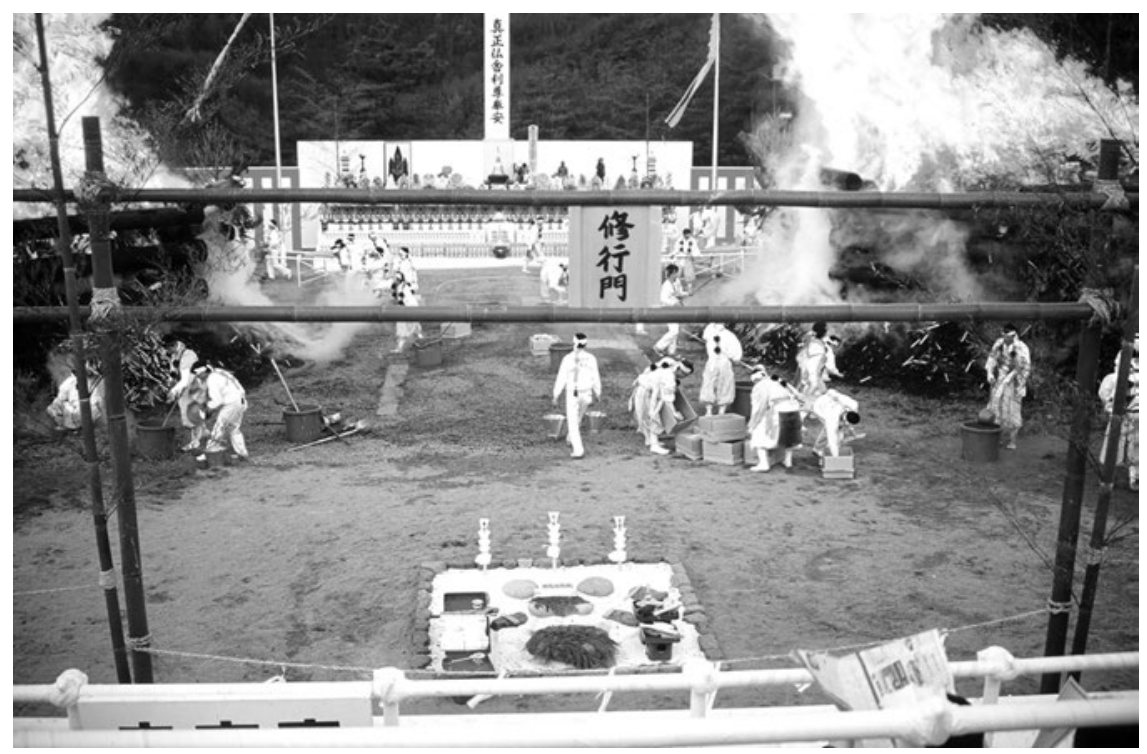

Fig. 3.1 The two pyres at the Stars and Fire Rites Festival 1986/1987. Photo courtesy of Ian Reader. From the Photo Archives of the Nanzan Institute for Religion and Culture, Nagoya, Japan.

Agonshū's major media event was, and still is, the Hoshi Matsuri. ${ }^{16}$ The annual event is held on February 11th at the Yamashina main temple near Kyoto. ${ }^{17}$ During the matsuri, a goma (fire rite) is performed. The festival starts at seven in the morning with a procession of members dressed as yamabushi (mountain ascetics) in front of an altar decorated with offerings to Buddha and on which Agonshū's sacred relic (shinsei busshari) is enshrined. The procession is accompanied by fireworks, the blowing of conch shells and dramatic symphonic music. The yamabushi perform several rituals and afterwards, Kiriyama-who is seated in a special seat called the "lion seat" (shishiza) which symbolizes the place where a Buddha is seated-blesses the torches that are used to light the pyres. The fires, around eleven metres in diameter and seven metres high, are lit on the two massive pyres dominating the ritual space while dramatic orchestral music plays in the background. The performance continues until late afternoon, with participants chanting sutras accompanied by taiko drumming, and several million wooden sticks ${ }^{18}$ written on by members and participants, will be burned. The two pyres (Fig. 3.1) represented the two mandala worlds of the esoteric tradition, taizo (womb) and kongō (diamond). One pyre, shinkai dan, is for the realisation of the prayers and the wishes of living people, while the other, bukkai dan, is for the liberation 


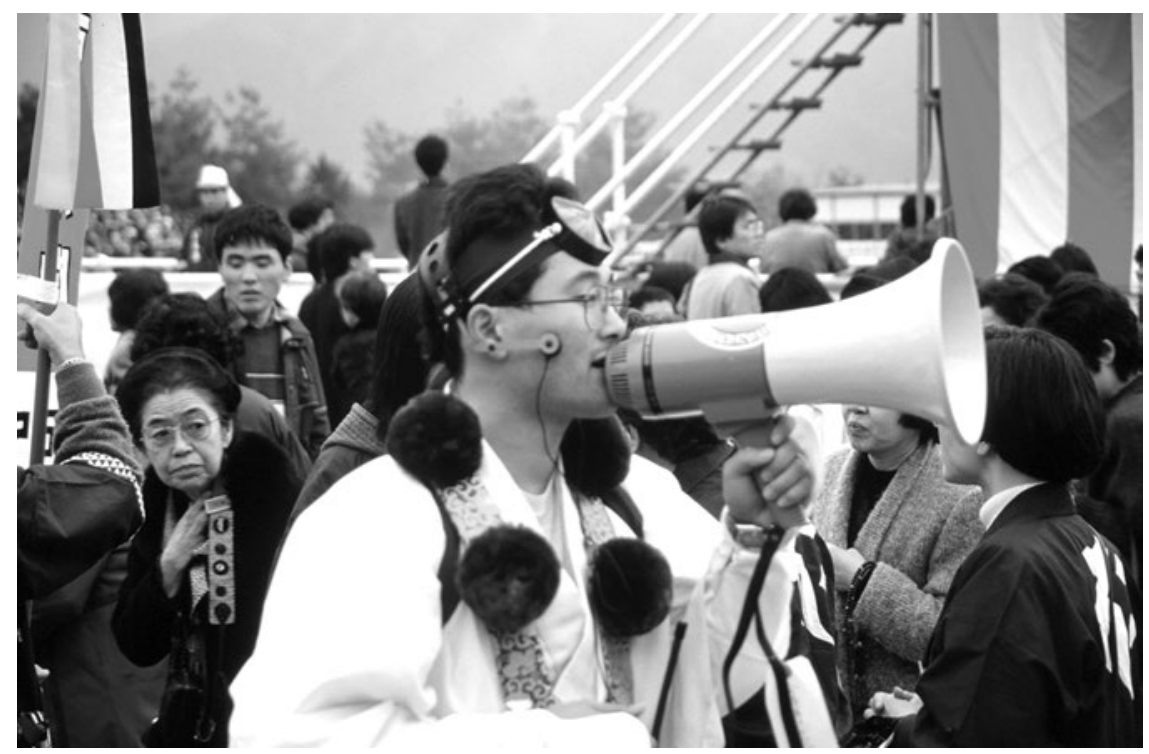

Fig. 3.2 Participant at the Star Festival with loudspeaker, 1986/1987. Photo courtesy of Ian Reader. From the Photo Archives of the Nanzan Institute for Religion and Culture, Nagoya, Japan.

of the spirits of the dead. ${ }^{19}$ Consequently, two types of wooden sticks can be purchased. One, called kūyo gomagi, is intended for the ancestors, and their name(s) will be written on it and burned on the bukkai dan, while the other, kigan gomagi, will be inscribed with wishes and requests for this-worldly benefits and burned on the shinkai dan. ${ }^{20}$

At the site, visitors are welcomed by members shouting, "Okaerinasai" ("Welcome back", Fig. 3.2), and huge loudspeakers explain details regarding the rituals (how many participants are attending, how big the pyres are, how many million of wooden sticks will be burned and so on) and the significance of the rituals (to protect Japan, ${ }^{21}$ but also to promote world peace).

The event advertising campaign focuses on the grand and spectacular nature of the event and at the site of the Festival, an elaborate media centre is set up that utilises an entire building. The coverage of the event is total. Cameras are even mounted on helicopters to give a bird's eye view of the event, which is transmitted live to all Agonshū centres in Japan and on some local TV stations. At the same time, the ritual "contains media and media devices" (Grimes 2002, 222) to convey a sense of intense drama and spectacle. The description by Reader of the ritual in 1980s seemed almost unchanged when I attended in the mid-2000s:

[. . .] the helpers wear headphones and have two-way radios [Fig. 3.3] (including may of those dressed as yamabushi, making a rather interesting 
cameo picture of the traditional costume of the mountain ascetic topped off with the technology of the modern age) to keep things coordinated. [. . .] Teams of yamabushi take turns in beating great rows of drums and chanting through microphones, to accompany the activities of those hurling gomagi on to the fire, and especially composed dramatic music is played through the banks of loudspeakers to add to the overall effect.

(Reader 1991, 224)

Furthermore, media operators (cameramen, photographers) and their devices enter the main ritual area, the sacred space that traditionally is reserved for yamabushi, while the public is seated on temporary stands. The spectacle promised by the advertising campaign preceding the event is guaranteed and religious entertainment (including fortune-telling, traditional dance and music performances, entertainment for children and families and food) is offered all day long at the sacred centre.

A similar ritual (on a smaller scale and with only one pyre) is occasionally performed overseas by Kiriyama and Agonshū's yamabushi, such as, for example, the Fire Rituals held near the Auschwitz-Birkenau concentration camp in 2006 to commemorate Holocaust victims. During these performances, a procession will similarly introduce the performers to the main ritual area and the same ritual actions are performed before lighting up the pyre. In these cases, the ritual is often preceded by a discourse by Kiriyama

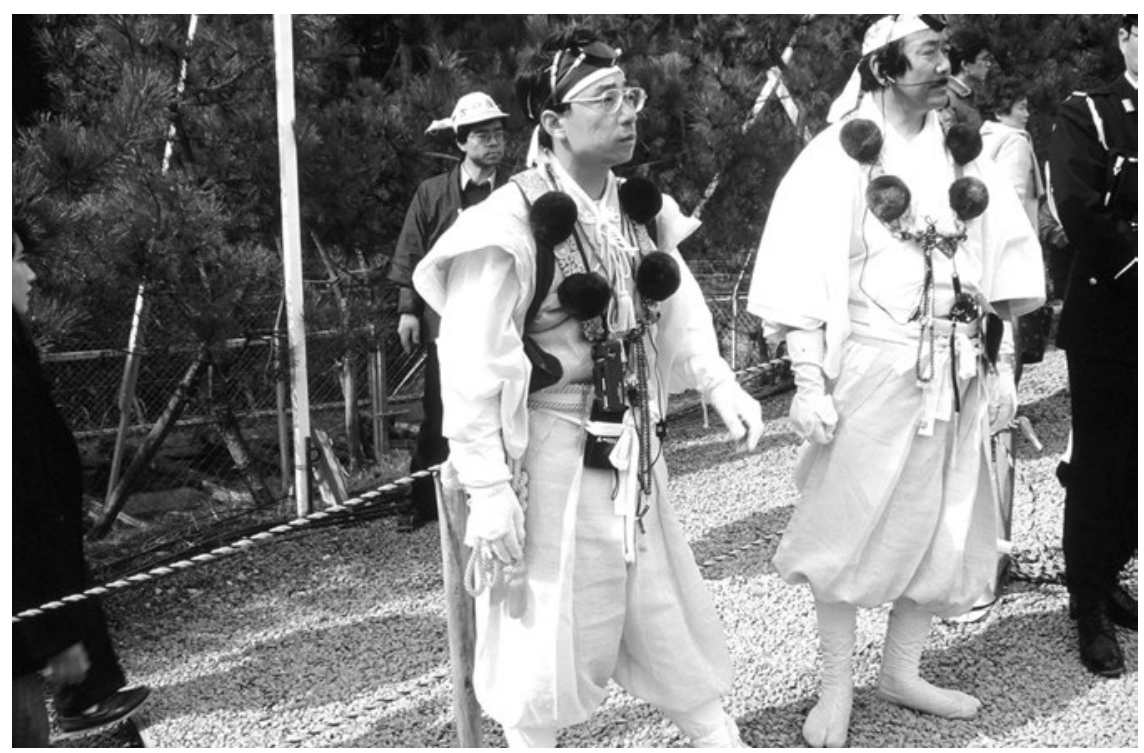

Fig. 3.3 Members with headphones and two-way radios participating in the Star Festival 1986/1987. Photo courtesy of Ian Reader. From the Photo Archives of the Nanzan Institute for Religion and Culture, Nagoya, Japan. 
explaining the reasons why the ritual is being performed in that specific location and by greetings from several local authorities.

The Hoshi Matsuri and overseas rituals are transmitted live via satellite at Agonshū centres around Japan. Participants who couldn't attend in person gather at the centres a few hours before the beginning of the ritual. As with the indoor rituals, they are greeted at the entrance by members and they receive information pamphlets and advertising leaflets. Usually they also receive a special present, such as a book or a flower, prepared for the special occasion. The festival atmosphere and religious ambiance are recreated at the centre, albeit on a smaller scale. For example, on the ground floor at the Tokyo centre, counselling and fortune-telling services are offered and participants can also buy amulets, wooden sticks or other souvenirs of the event. The atmosphere is louder than during the monthly ritual gathering, with members chatting outside the main hall or in the "coffee corner" provided. A few minutes before the start of the ritual, however, they will all sit quietly and wait for the beginning of the live programme.

Yet, the transmission of the Hoshi Matsuri or other outdoor goma rites (for example, the occasional ritual performed overseas) is the complete opposite of Agonshū's closed-circuit (that is, members and guests only) broadcasts of indoor rituals. Instead of a camera and microphone being the eyes and ears of distant worshippers, the media enter into the ritual. The ceremonies are not just transmitted by the media, but recreated by them. The viewers experience not just being there, but they see more than those attending the ceremonies in person: they can see the ceremonies from different points of view, read supplementary explanations on the screen, enter in the ritual space and enjoy close-up images of performers and ritual objects. In this case, the camera is not discreet, but intrusive or sometimes distant. Its rhythms are not the rhythms of the ritual: long sequences are alternated with quick changes of scene and zooming. The transmission allows the viewers to see details, and the on-screen written explanations (or simultaneous translation of talks) give them more information about the different phases of the ceremony. The viewers become omniscient, and this compensates for the lack of physical proximity between the charismatic leader and his followers. The members watching the festival at the centres participate actively in the rite, praying during the central part of the ritual and loudly clapping after Kiriyama's talks, but above all creating a festival atmosphere at the centre. The big festivals are an extraordinary occasion also for the members who watch them on the screen. The rules of daily life in the centre are temporarily suspended and a festive atmosphere is created. For example, on the day of the transmission of the fire rite performed in Poland in June 2006, the Tokyo centre offered gifts, free drinks and fortune-telling services for the visitors. The participation through the screen cannot reproduce the intensity of the live ritual, in particular the physical sensation of the heat of the fire and smoke, but the planned performance of the event is perceived as extraordinary. Members attending these special events told me that they took a day's leave from work to attend it. In such ways, the creation of the special 
event and the presence of cameras announce that "this is an important event" (Grimes 2006, 4) and validate the ritual. Furthermore, viewing the transmission allows the participants to take part in a "virtual pilgrimage": without leaving their seats, they are transported around the globe and can contribute to the circulation of Agonshū's universal message.

The transmission of the event recalls some of the characteristics that Dayan and Katz (1992) attributed to media events. Although in this case, it is not an event that has the whole world watching it, such Agonshū events, with their extended community of members and visitors, the interruption of everyday life (such as the festive and extraordinary atmosphere at the centres), their live broadcasts and the "reverent, awe-filled character of the narration" (Katz and Liebes 2007, 158) have shared characteristics with the bigger-scale events theorised by Dayan and Katz. The transmission and recreation of the ritual allow the viewers not only to participate in the ritual, chanting and following the ritual actions, but to create the feeling of "being there", with the leader, inside the ritual sacred space, where only initiated practitioners (and media devices) can enter.

\section{MEDIATED RITUALS AND AFFIRMING "WHAT WE SHARE”}

Over the last three decades, ritual performance and consumption in Agonshu have evolved in new forms modelled by the media, while the mediated form of the rites has affected the direct experience of participants. The ritual attended at a distance offers to the viewers not only the possibility of being there, but also of being an active protagonist.

The different use of satellite transmissions depending on events shows different image strategies. In the case of indoor rituals, the focus is on the sense of community of the members who participate together, but at different physical locations. The aim of the (virtual) nationwide temple is to reinforce the inner cohesion of the members and the proximity between the leader and the members. Regarding the broadcasting of outdoor rituals, the focus is on creating a spectacular event that "serves as an affirmation of the vitality and prominence of their religion" (Reader 1991, 225) for members, and an occasion to participate in a special event, although at a distance. For non-members, it is a demonstration of the power and wealth of the group that might help persuade other people to join. Agonshū's self-proclaimed mission of world salvation is reinforced by its goma rituals performed overseas, which become an expression of Agonshü's universal message and its role in world salvation. In both cases, media have been used to create what Reader defines as a "user-friendly" religion:

[. . .] the term [. . .] in this context in many ways captures the ethos Agonshū is attempting to put across to its potential members. It points to its inherent modernity that in many ways balances and reinforces the 
intrinsic traditionalism of its teachings, and also implies the relaxed, open and accessible style that Agonshū, like other new religions, wishes to maintain so as to allow its members to feel at home in it.

Although they make reference to traditional practices, the transmission of the rituals challenges and transforms the nature of esoteric rituals, in which secrecy is an important aspect reinforcing its believed power and the authority of priests who perform it. In Agonshū's broadcasts, the viewer's gaze can enter the ritual and unfold its secrets. The videos "democratise" the rituals, making the teaching accessible to all viewers and eroding differences between leader, members with the rank of yamabushi and others. Material objects, such as the sacred relic, are also made visible. This erosion is, however, "virtual", because in practice, the video eliminates direct interactions and contact between the leader and members.

Finally, another way in which viewers can experience the ritual is by sitting in front of one of the TVs alone and watching the recorded ritual on DVD. This represents a very different form of accessing the ritual, as a solitary experience, but still in the same place (DVDs can only be watched at Agonshū centres, in open spaces). The reproduction of the ritual on DVD again transforms the ritual. It is no more a unique experience, but one that can be repeated and reproduced at hoc and used as advertising material. The repetition of the ritual can be used by members to remind them of the spectacular events produced by the group, or it can be used as a didactic support during training and teaching sessions.

\section{THE EXPERIENCE OF A PLACE}

Both indoor and outdoor types of satellite transmissions have in common the place of consumption of the media product. Indeed, the only places where one can see the satellite transmissions and the DVD reproduction of rituals are at Agonshū's centres around Japan. ${ }^{22}$

The rituals, both live and mediated by the screen during the satellite broadcasts, cannot be consumed in a private space (i.e. at home), but only in a public space controlled by the group. The centres are open to all visitors, but all must register at the entrance or show their membership card. The consumption of the videos, therefore, is not privatised, but collective. This indicates a tension in the image strategy of the group between opening up publicly and reaching a wider audience and, at the same time, still considering the communal dimension and face-to-face interaction essential for the members. As a consequence, the potentiality of satellite broadcasting (that is, the possibility of reaching everyone individually in their houses, like the televised performances of American televangelists) is restricted by the controlled (and clearly defined) space of the group's centres. The space of the 
centre becomes the viewing environment that is structured to contain the crowd and at the same time to focus attention upon the screen.

Gathering at the centre and attending the rituals performed on the screen seem, however, to entail not only a consumption of the ritual, but also an experience of it. In his work on cinema, Casetti provided a twofold definition of the experience:

On the one hand, it refers to the act of exposing ourselves to something that surprises and captures us ('to experience'). On the other hand, it relates to the act of reelaborating this exposition into a knowledge and a competence, so that we are then richer in the face of things, since we are able to master them ('to have experience').

In the case of satellite videos, the experience of a place, the temple where members converge and share the same emotional experience, becomes crucial for understanding the role of mediated rituals. Differently from the spectators in a movie theatre, the viewers of Agonshū's screened rituals are asked to engage with what they have seen as an interpretative community, but also to be active participants in the event-attendees contribute to the ritual chanting and clapping, and when the ritual is performed live, the presence of cameras and videos screens also reminds them that other people are watching. The viewer is not a passive viewer, but is empowered because the ritual could not exist without $\mathrm{him} / \mathrm{her}$. The screened ritual is a ritual of "togetherness" that includes both members participating live and members watching through the screen.

\section{AGONSHŪ AFTER AUM}

When I started attending regularly the rituals (both performed live and transmitted via satellite broadcasting) at the Tokyo centre in the mid-2000s, I noticed that the beginning of Kiriyama's speech after the performance was exactly as described by Reader in his account from the 1980s:

Holding a microphone he began a dialogue which started as follows:

KIRIYAMA: O-genki desu ka [Are you well?]

AUDIENCE: Hai, genki desu [Yes, we are.]

At this Kiriyama shook his head a little and said that they did not sound as if they really were well: he wanted them to say it again, but this time with feeling. They did, shouting loudly and in unison. (Reader 1991, 226)

The speeches also always ended with the leader inciting the audience with his signature catchphrases:

Saa yaruzo! (Let's do it!)

Kanarazu seikō suru! (I will certainly succeed!) 
Watakushi wa totemo un ga ii no da! (I have a lot of luck!)

Kanarazu umaku iku! (I will certainly do well!)

Zettai ni katsu! (I will definitely win!)

Also, the content of the leader's monologue has changed only slightly over the years: Kiriyama talks about his future projects, uses himself as an example of someone who was able to become a successful man after liberating himself from the negative influence of ancestors' spirits and encourages his audience to develop a positive attitude.

When I compared my field notes from 2006-2007 and Ian Reader's account from the late 1980s regarding both indoor rituals and the Hoshi Matsuri, it was clear that they shared several similarities. The transmission of the rituals and the main events were still organised exactly in the same way and, as mentioned above, even the leader's talks followed an almost identical structure. The most striking difference between the two accounts is the number of participants reported for each event. While the number of participants during the Hoshi Matsuri has remained almost unchanged (around 500,000 people attending the event were usually reported in the media in the late 1980s, and similar figures are reported now), the number of individuals attending the monthly rituals has dropped significantly. Reader described a large crowd (about 2000 people) attending the tsuitachi goma in July 1987 and Agonshū volunteers lining up at the nearest subway station to greet people and guide them to the centre $(1991,225)$. When I have attended the same event, on more than one occasion, I have only counted 300-400 participants, and volunteers were only outside the group's building. However, when I attended the event organised for the performance of the goma rite in Auschwitz in 2006 and the New Year events in 2009 and 2014, the main hall was crowded and could not fit all the participants.

One of the reasons for this significant change should be ascribed to both the effect that the Aum Affair (as already discussed Chapter One) had on Agonshū in mid-1990s and the decrease in membership in the group, due also to a leader who is no longer able to appear as forceful as before. ${ }^{23}$ After the Aum attacks and the subsequent criticisms made in the media about religious groups that appeared to differ from the mainstream, Agonshū was one of the movements that came under attack for its massive use of media and for its spectacular image. Furthermore, the group, as mentioned in Chapter One, was associated with Aum's leader because Asahara was member of Agonshū for a brief period before founding Aum Shinrikyō. The negative publicity derived by this association triggered a defensive reaction by Kiriyama himself, who published a book to explain the relationship between Aum and Agonshū (Kiriyama 1995).

The group reacted by becoming withdrawn. The Hoshi Matsuri continued, but advertising campaigns decreased, as did Agonshū's presence in the media. In the late 1990s, the Agonshū website, for example, was just a simple information page on the group's teachings and it did not provide any 
information about centres' addresses or contact details. In the last few years, however, the group has shown an interest in the Internet and the website has been completely renovated. However, despite the new attractive website, thus far it has not appeared to develop a striking online presence and its use of the Internet is still limited to non-interactive communication, with, for example, very limited use of social media (Baffelli 2011). In 2012, a new advertising campaign created by Dentsū was launched to promote the Hoshi Matsuri, showing images of young men and women in yamabushi clothes (Fig. 3.4).

Another main change since 1995 has been the increasing numbers of goma rituals performed outside the main centres and in particular, overseas. The event has been performed (among other places) in New York (2000), Auschwitz (2006) and Jerusalem (2008). According to Alexandre Benod (2010), it is difficult to understand if the aim of these performances is more related to an internal strategy (to confirm to members the importance of the leader and his message) or an external one (the necessity for the group to expand overseas). Probably both are important, and the transmissions of rituals performed overseas play an important role in placing the leader's message in a universal context and reinforcing the idea of Agonshū's legitimation as a religious group with an international profile.

These changes of image that have occurred over the past ten years reflect an attempt to renovate the image of the group. However, none of these attempts has proved successful yet. The fact that Agonshū's satellite broadcasts are still identical to those broadcast almost thirty years ago seems to indicate stagnation in the group's image strategies, which are fixed and

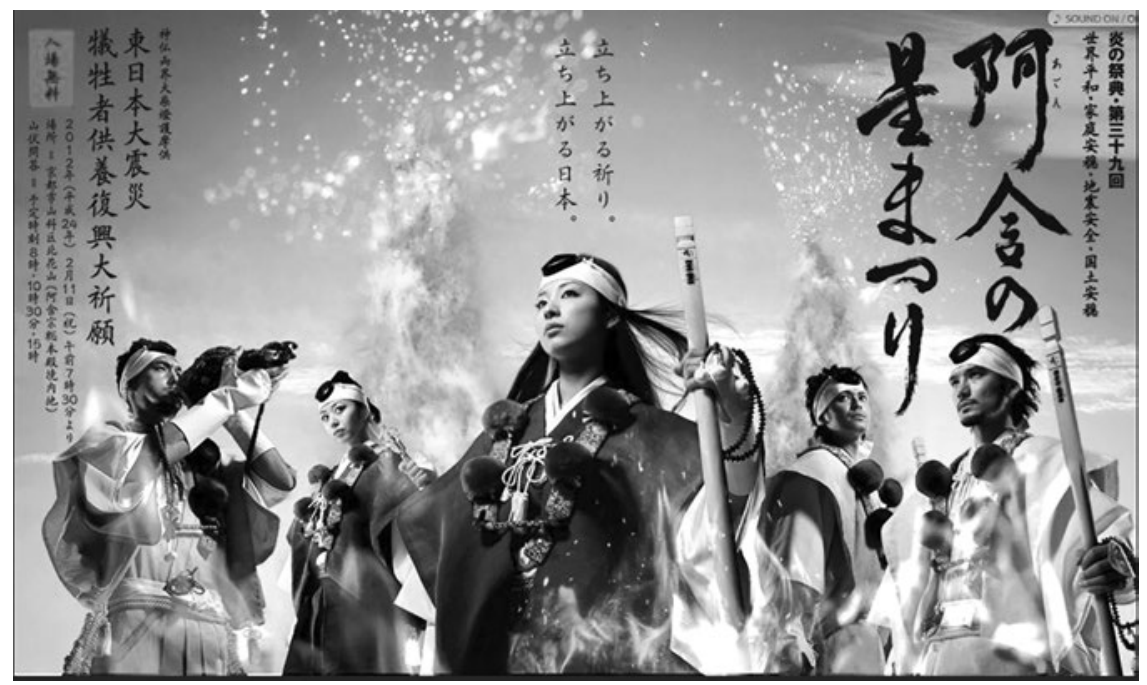

Fig. 3.4. Agonshū's advertisement poster, 2012. 
haven't evolved in step with the developments of new technologies and new media. ${ }^{24}$ In my conversation with a long-term member during the Mando senzo kuyō (Memorial Festival for the Ancestors) in July 2014, she expressed her worries about the struggle to attract new members, which, in her opinion, was due to the fact that Agonshū had lost its "distinctive feature" (tokushoku) that made it attractive to people in the 1980s and early 1990s. The ageing leader and members will also represent a challenge for the future of the organisation. When I attended the New Year event in 2009, the Tokyo hall was crowded and some members told me that they were there because they weren't able to travel to Kyoto for the Hoshi Matsuri anymore and they wanted to see the leader, because that could have been one of his last performances. In May 2012, the transmission of the meitokusai showed a video of a very frail leader who was travelling in a boat on the ocean to pay respect to the Japanese soldiers who died during the World War Two. Similarly, at the New Year Festival in 2014 and the above-mentioned Memorial Festival in July 2014, the centre overflowed with visitors and the leader was still performing the rituals and addressing the members, despite evident physical and mobility difficulties. The image and message promoted by these videos and the average age of the participants during the ceremony seemed in contrast with the image of the young yamabushi promoted by the Hoshi Matsuri advertising campaign in 2012.

\section{CONCLUSION: THE LIMITS OF MEDIATED RITUALS AND THE IMPORTANCE OF FACE-TO-FACE INTERACTION}

The adoption of modern audio-visual media indeed transforms practices of religious mediation. The power of the media, however, should not be overestimated. The process of transforming traditional practices and rituals involves complicated negotiations and cannot be attributed entirely to the use of media. In the case of Agonshū, the successful use of new media devices was supported by a flexible doctrine and a focus on esoteric and millennial topics that attracted new members in the 1980s and that was combined with a strategic marketing plan. The employment of advertising agencies and the setting up of a Public Relations Department staffed by communication experts led to the creation of an attractive package (spectacular events, appealing teaching, charismatic leader and up-to-date technologies) that led to growth in membership and public attention in the 1980s.

As was mentioned previously, Agonshū was not the only Buddhist organisation to start using satellite broadcasting in the 1980s. Other groups saw in the new technology a useful educational tool or a way to restructure the interactions between the leader and members. In Chapter Two, for example, I discussed how satellite broadcasting was used by Sōka Gakkai to reaffirm direct contact between the leader and members and to weaken the power of local intermediaries. For Agonshū, satellite broadcasting became both an 
integrated part of the practices and a reinforcement of the group's image. The example also showed that watching videos is not just consumption, but an experience that can affect members' commitment and religious authority. Agonshū's example also shows how traumatic events can impact the development of image strategies, with the results that the movement, which was considered a model of the new religions at the forefront of technology, now looks rather backward and out of date in both the way it is presenting its message and in its content. Agonshū seems to be struggling to make the shift from early new media (such as satellite broadcasting), which, linked to a flexible doctrine and messianic optimist, were the basis of its success in the 1980s, to the latest new media (websites and social media), and it seems to have lost, over the years, its status as a user-friendly religion. However, the resistance to employing new media, such as, for example, the creation of a dedicated channel for the online broadcasting of rituals, may also be connected to the importance placed by Agonshū on face-to-face interactions and physical communions between members. Indeed, satellite broadcasting allows the members to be physically distant from the space where the ritual is performed but still together at the temple, in a sense reaffirming the importance of physical participation in rituals, while online transmission will completely relocate the ritual event to a non-physical space and completely transform participants' experiences of ritual actions.

\section{NOTES}

1. For a detailed history of Agonshū and a more detailed discussion of its teachings, see Inoue et al. (1994); Numata (1988); Prohl (1995); Reader (1991; 1994).

2. It is not uncommon for people in Japan who undergo a religious awakening and become leaders to take on a new name.

3. On Kiriyama's publications, see Numata (1988, 61-65).

4. See the explanation of the three methods on Agonshü's website: http://www. agon.org/about/about_000010.php (in Japanese). Accessed July 22, 2015. http://www.agon.org/en/about/page_a3ml (English), both accessed July 11, 2015. See also Clarke ed. (1999, 136).

5. http://www.agon.org/en/history/page_a.html. Accessed July 22, 2015.

6. It is difficult to estimate accurately the membership of religious organisations. The numbers provided are based on Agonshū's official estimate (see Bunkachō 1982; 1986), but, as Ian Reader has pointed out, the number of dedicated members was probably much lower, (around 100,000, see Reader 1994, 39)

7. Personal communication with former PR representative of Agonshū, June 2006.

8. Personal communication with former PR representative of Agonshū, June 2006.

9. As for other new religions (see, for example, Chapter One in this volume), Agonshū published manga to reach a wider public, although they did not constitute the main media forms used by the group. In the series mentioned, the narratives are centred around the idea that one could acquire supernatural powers (chōnōryoku) through Agonshü's esoteric spiritual practices. The main 
character is Morio Mayura, a beautiful young woman who meets an unemployed young man, Kudō Kazuki, and introduces him to yoga practices and to the esoteric teaching of her "guru", Kiriyama. The story is interrupted by explanations of teachings and illustrations of practices, such as energy points, or chakra, and mudra (ritual gestures) performed with hands and fingers.

10. Personal communication with former PR representative of Agonshū, June 2006.

11. See, for example, Shükan Bunshun June 4, 1987, 123-127; Shükan Sunday July 9, 1987; 232-233; Shükan Sunday September 10, 1987, 192-193.

12. Japan's national public broadcasting organisation (Nippon Hōsō Kyōkai, NHK), for example, started experimentally broadcasting TV programmes using a BS-2a satellite in May 1984. After these successful experiments, NHK started regular service (NTSC) and experimental HDTV broadcasting using BS-2b in June 1989. See: https://www.nhk.or.jp/bunken/english/about/history. html. Accessed July 22, 2015.

13. Personal communication with former PR representative of Agonshū, June 2006.

14. For a detailed description of the tsuitachi goma, see Reader 1991, 225-227.

15. Personal communication with former PR representative of Agonshū, June 2006. My translation.

16. The complete name of the event is Shinbutsu ryōkai daisaitō gomaku, which the group translates as Shinto-Buddhist Sacred Fire Rite. In English, the festival is also called the Stars and Fire Rites Festival. See: http://www.agon.org/en/ schedule/page_b.html. Accessed July 18, 2015.

17. Promotional videos of the event are available on the YouTube channel of the group: www.youtube.com/user/agonpublicinfo. Accessed July 22, 2015.

18. According to Reader, one million wooden sticks were purchased in 1979 and the number rose to over 30 million in 1988 (1994, 54). Similar data on the increase in visitors and number of wooden sticks sold are reported also in an article published in Kyoto Shinbun, October 21, 1993.

19. Until 1981, only one pyre was used (covering both purposes), but the significant increase in the numbers of participants and wooden sticks burned led to the creation of a second fire.

20. For a detailed explanation of different gomagi, see: http://www.agon.org/ hoshimatsuri/moushikomi.html. Accessed July 11, 2015.

21. The nationalistic connotations of the event have been discussed by Reader (1991; 2002) and Prohl (2004). February 11th, now known as Constitution Day, was previously called National Foundation Day and named after the myth according to which the legendary first emperor of Japan, Jimmu, descendant of the sun goddess Amaterasu, descended to earth and created Japan on that date. The Hoshi Matsuri was introduced in 1970 and moved to February in 1975.

22. The Hoshi Matsuri is broadcast publicly on some local TV channels, but this only in a 30-minute-long programme.

23. Although official membership numbers provided by the group show a little increase over the last decades, during informal conversations with members, they admitted that the number of members is stagnant and there are very few young members joining the group. Reader reported similar conversations with a priest from Agonshū in Kyoto (2012, 20).

24. It is also possible that as Kiriyama (and members of the board) has aged, he has become less inclined to move away from a familiar communication strategy and to experiment with new technologies. 


\section{Mediating the Leader's Image \\ Kōfuku no Kagaku's Communication Strategies in the 1990s}

Kōfuku no Kagaku (literally, Science of Happiness), also known as Happy Science, ${ }^{1}$ was founded in 1986 by Ōkawa Ryūhō. During the early 1990s, the group registered a rapid increase in membership and received extensive coverage in the Japanese press for its large advertising campaigns and spectacular public events, its legal action against a publisher, Kōdansha (the so-called Kōdansha furaide jiken, Kōdansha Friday Affair, which I will deal with below) and its severe criticisms against other new religions, such as Aum Shinrikyō and Sōka Gakkai. It also appeared in some international magazines, such as, for example, the Financial Times and the Los Angeles Times, for similar reasons (see Farley 1995; Tennant 1995; Thomson 1991). In this chapter, the mediation practices adopted by Kōfuku no Kagaku and its reaction to critical reporting in the press will be discussed in order to investigate the potential impact of religion-media dynamics on the branding of religious leaders' images and on the relationship between leaders and members. Therefore, after a brief introduction of the leader and his teachings, the relationship between Kōfuku no Kagaku and the mass media will be investigated by focusing on three major events: the advertising campaign of 1991 (and the text used for the advertisement of Ōkawa's book Eien no Budda ["The Eternal Buddha"], 1991c), the major event held for the leader's birthday on July 15, 1991 and the Kōdansha Friday Affair, which began in September of the same year.

\section{ŌKAWA RYŪHŌ AND THE SCIENCE OF HAPPINESS}

Ōkawa Ryūhō was born Nakagawa Takashi on July 7, 1956 in Kawashimachō, Tokushima Prefecture, on the island of Shikoku. ${ }^{2}$ His father, Nakagawa Tadayoshi, who played an important role in the establishment of Kōfuku no Kagaku, is said to have been interested in different religious traditions and to have been in contact with other new religions, including Seichō no Ie and the GLA (Numata 1995, 183), whose influences can be seen in Kōfuku no Kagaku's structure and teachings. Ōkawa graduated from the prestigious University of Tokyo, but failed to gain admission to the 
postgraduate programme. This failure, however, would be later reinterpreted as a sign from the "high spirits" (kōkyürei) that he was destined to become a religious leader (Ōkawa 1997, 345; Ōkawa 2001a, 171-172). After graduation, Ōkawa started working for a Japanese trading company. On the afternoon of March 23, 1981, he experienced his first spirit possession and what he would later call, in Buddhist terms, his "enlightenment" (daigo):

Suddenly, I sensed an invisible presence with me in the room, and almost simultaneously understood by intuition that whatever it was wished to communicate with me. I ran to get a pencil and some blank cards. My hand holding the pencil begun to move as if it had a life of its own. On card after card it wrote the words, 'Good News', 'Good News'.

'Who are you?' I asked. My hand signed the name 'Nikko'. I was experiencing automatic writing under the control of Nikko, one of six senior disciples of the thirteenth-century Buddhist saint Nichiren.

(Ōkawa 2001a, 174)

According to his autobiographical account, a week later, Ōkawa received a message from Nichiren ${ }^{4}$ himself: "Love others, nurture others, forgive others" (Hito o aishi, hito o ikashi, hito o yuruse, Ōkawa 1997, 351; Ōkawa 2001a, 175). The following June, according to Ōkawa, the spirit of Takahashi Shinji, founder of the GLA, whose books Ōkawa had read in the months preceding the event (Ōkawa 1997, 349), recognised him as the "true reincarnation of the Buddha" ( shaka no sairai, Ōkawa 1997,352) ${ }^{5}$ and invited him to form his own group (Ōkawa 1997, 353). Later in the same year, communications from spirits through automatic writing (jidoshoki) were replaced by channelling experiences. The first group of publications attributed to Ōkawa is a series of reigen (spiritual words) received by him and recorded by his father. The books were initially published under his father's pen name, Yoshikawa Saburō (to avoid problems with his employer according to his own account, Ōkawa 1997, 366) and included his first book, Nichiren no reigen ("Spiritual messages from Nichiren", Yoshikawa 1985a) and messages from different religious and philosophical personalities, such as Kūkai, the founder of the esoteric Shingon Buddhist sect (Yoshikawa 1985b), Jesus (Yoshikawa 1985c), the sun goddess Amaterasu (Yoshikawa 1986a) and the philosopher Socrates (Yoshikawa 1986b). In July 1986, in order to follow the spirits' calling, Ōkawa quit his job, and in October of the same year, he established Kōfuku no Kagaku and changed his name to Ōkawa Ryūhō. In 1987, the first edition of Taiyo no ho ("The Laws of the Sun"), which is the first book that is not a collection of spiritual messages and that contains explanations of Kōfuku no Kagaku's theology, was published by the publishing firm Tsuchiya Shoten, and it is still considered by members as one of the central texts for learning Ōkawa's teachings ${ }^{6}$ together with other texts in the Laws series such as Ögon no hō, "The Golden Laws" (Ōkawa 1990a), and Eien no hō, "The Laws of Eternity" (Ōkawa 1990b). 
Kōfuku no Kagaku started as a small study group that gathered in a rented apartment in Tokyo. Initially, the selection of members was quite rigorous, and participants were required to read several texts by the leader and pass a qualification exam (Fukui 2004, 71). According to Astley $(1995,358)$, this resulted in the creation of a core group of highly motivated members and in the reinforcement of the group's sense of identity. In the initial period, proselytism was mainly based on members inviting relatives, friends, and co-workers to read Ōkawa's books and to attend the group's conferences and seminars, such as public talks (zadankai) the first of which was held in Nippori, Tokyo, in November 1986, and bigger public lectures (kōenkai) which started in in Ushigome in March 1987 in front of an audience of about 400 people (Astley 1995, 357; Nijū Isseiki 1991). In the first period, group activities were mainly based on group discussion and research on happiness and the "divine truth" (shinri). In 1989, the centre of the group moved from a small rented flat to an expensive apartment in the Shinjuku area (Fukui $1999,150)$ and its missionary activities intensified. In November of the same year, Ōkawa launched the "Project Sunrise 90" (Sanraizu 90 keikaku) which aimed at reaching 50,000 followers by the end of 1990 . The group's lectures were now accessible to the general public, subscription fees were reduced and it became possible to join the group without a member's recommendation. A new system of membership was also introduced, with a new category of "friendship members" (shiȳu kaiin, literally "Friends-of-the magazine members", Astley 1995, 353), which made it easier to join the movement (Fukui 2004, 71) and indicated "the move towards a mass-oriented system" (Astley 1995, 359). According to the figures reported by the group, membership in 1990 increased from 10,000 members in January to 30,000 by the end of May, 60,000 by the end of June and 77,000 by the end of July (Fukui 1999, 150).

In his numerous books, Ōkawa syncretically draws from different traditions, both religious-Indian, Chinese and Japanese Buddhist schools and Christianity-and philosophical, from Greek philosophy to modern thinkers. According to the presentation of Kōfuku no Kagaku on its websites and in its pamphlets, the main aim of its teaching is to help people to attain "true happiness" (also called satori in Japanese, "enlightenment"), to spread happiness and to create an ideal world. Therefore, the three main concepts are ai (love), satori (enlightenment) and the yütopia kensetsu (creation of Utopia) in order to create "universal happiness and worldly harmony" (Pokorny and Winter 2012, 32). The eschatological view of Kōfuku no Kagaku, rather than marking the end of time and the creation of a new world in the future, is in continuity with the present time and space, in order to create-through the application of Ōkawa's teaching to daily life activities and to relationships with colleagues, relatives and friends-an ideal world on earth, a world that already existed in a mythical past and that will be restored with the creation of a "global utopia on Earth" (chikyū yūtopia, or, in other publications, "eternal Utopia" kōkyū yütopia). As a consequence, the realisation of this 
utopian world does not imply an apocalyptic event, but it is the result of transformations in personal relationships and lifestyles.

The utopian world is an idealised version of the present world. Regarding cosmology, the universe is considered as being formed by several dimensions, ${ }^{7}$ in which hundreds of historical figures (from Einstein to Chopin, to Mozart, Muhammad, Archangel Gabriel and so on) are assigned positions at different levels. Śākyamuni, the historical Buddha, Jesus and other religious personalities or philosophers of the ancient or modern world are collocated in the highest of these dimensions. El Cantāre $(\text { Eru Kantāre })^{8}$ is the most elevated spirit in the terrestrial group, whose ishiki (consciousness) is said to have manifested in various figures, including Hermes, Buddha and, in modern times, Ōkawa Ryūhō. Members, by studying the books of the leader, could attain happiness and transmit it to other people. In Buddhist terms, members of Kōfuku no Kagaku take refuge in the Three Jewels: the Buddha (Ōkawa), the Dharma (his teachings) and the Sangha (the believers' community). Furthermore, the teachings are based on four basic principles, "The Principles of Happiness" (Köfuku no genri), also known as "The Fourfold Path"(yonshōdō), referring to the Noble Eightfold Path of Buddhism (hasshōdō). These four principles are: ai (love), chi (wisdom), hansei (self-reflection) and hatten (development). The first includes six levels of love: instinctual love, love that loves, love that values, love that forgives, love as existence and love of the Saviour (Ōkawa's love); the second expresses the knowledge of "the divine truth" (shinri) as expressed by the Ten Commandments of Moses, by Jesus' teachings on love and by the Noble Eightfold Path of Buddha; the third is the act of reflection on oneself and on one's life, and this is a daily practice in Kōfuku no Kagaku; the fourth is connected to self-development and is the sum of the other principles. ${ }^{9}$ These principles were first introduced by Ökawa at his first conference in March 1987, and in 1990, a trilogy on these teachings was published: Kôfuku no genri ("The Principle of Happiness"), Satori no genri ("The Principle of Enlightenment") and Yütopia no genri ("The Principle of Utopia").

In 1991, the group announced the "Miracle Project" (mirakuru keikaku, Nijū Isseiki 1991, 91-93; Ōkawa 1997, 370) based on prophecies of its members increasing over a period of three years (Miracle 91; Miracle 92; and Miracle 93; Numata 1995, 194), and in March 1991, Kōfuku no Kagaku was granted official recognition as a religious juridical person (shīkyō höjin). The period from 1991 to 1994 can be seen as the peak of the expansion and visibility of the group and the number of members increased rapidly (Astley 1995, 352-354). This success was owed on the one hand to specific doctrinal and organisational choices, such as, for example, the introduction of the above-mentioned flexible membership system, and on the other hand, to an effective media campaign centred on the figure of the leader. It was in this period, and particularly in 1991 and 1992, that the group underwent the most radical changes in terms of its doctrine, which became more markedly Buddhist, and turned its leader, previously seen as a 
teacher, into the physical manifestation of El Cantāre, the central deity for Kōfuku no Kagaku. The following sections of this chapter will therefore focus on this critical period in the history of the group.

\section{“NOW IS THE AGE OF KŌFUKU NO KAGAKU”: THE MAJOR ADVERTISING CAMPAIGN OF 1991}

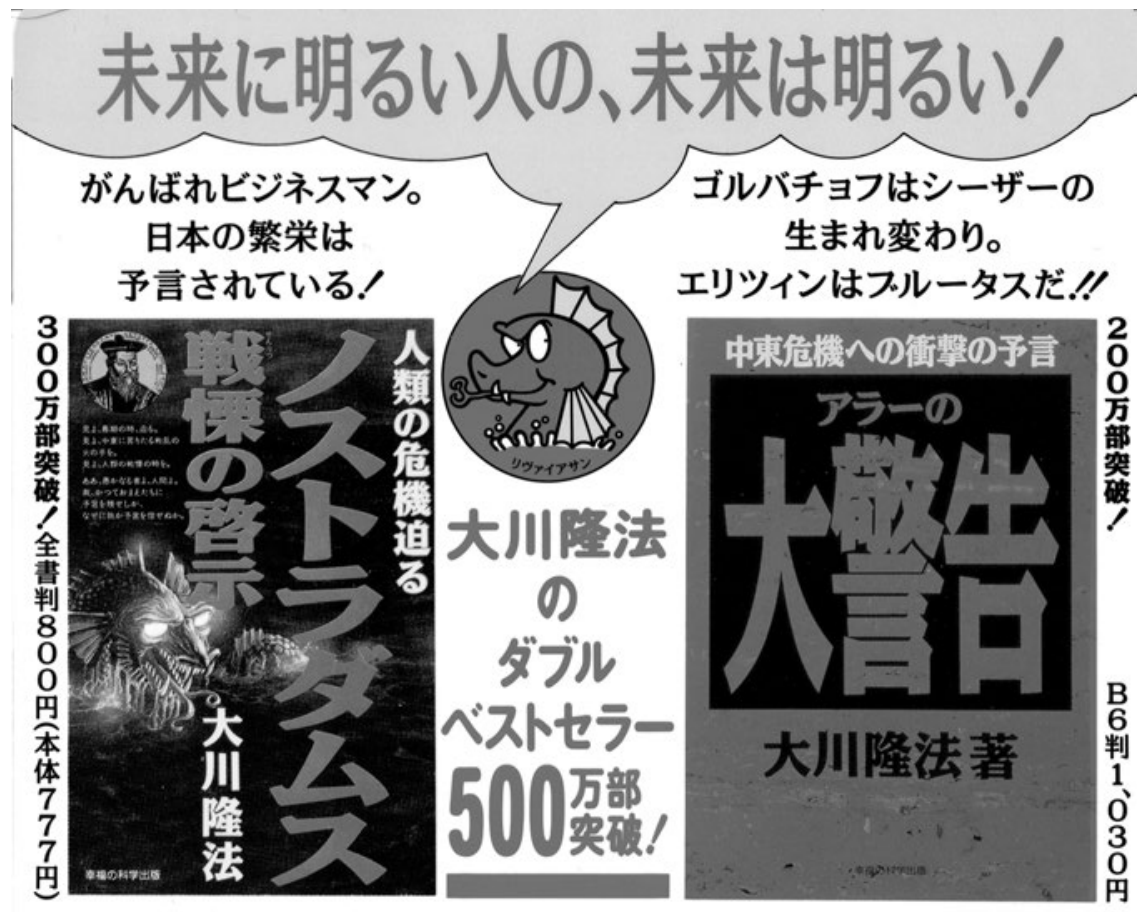

何が起こうとち、抯してはならない。私たちには「太威の法がある。超ミリオンセラー太陽の法

時代はいま、幸福の科学。央幸福の科学出版

Fig. 4.1 Advertisement stickers for Ōkawa Ryūhō's books Nosutoradamusu Senritsu no Keiji ("The Terrifying Revelations of Nostradamus") and Arā no Daikeikoku ("Allah's Great Warning”) with the slogan “Jidai wa ima, Kōfuku no Kagaku” ("Now Is the Age of Kōfuku no Kagaku”), 1991.

Since its establishment, Kōfuku no Kagaku has been using publications as its main means of propagation. Members are required to read Ōkawa's publications (initially, they were required to read at least ten books written by the leader in order to join the group) and proselytism activities are 
still nowadays centred on distributing and recommending Ōkawa's books. Indeed, for Kōfuku no Kagaku, "salvation comes through a book" (Kisala 2001b, 74) and members' testimonies are often centred around their life changes after reading one of the founder's books. Therefore, the publishing house, Kōfuku no Kagaku Shuppan (or IRH press in English), which was founded in 1987, represents possibly the most important organ of the group. Ōkawa is presented as a prolific, record-breaking author (to date, he is said to have published more than 1,900 books) and his books often appear in the bestseller rankings. ${ }^{10}$ The texts are also often modified and published in a new edition following changes in the doctrine. For example, the above-mentioned text Taiyo no Hō ("Laws of the Sun") was initially published in 1987 by Tsuchiya Shoten. In 1994, after the declaration of the leader as the current manifestation of a supreme deity, a new edition was released (Shin Taiyō no Hō, "New Laws on the Sun"), in which the new identity of the leader is explicit and the terminology more markedly Buddhist. In particular, the term kami (god) was replaced in the text by butsu (Buddha), and shinri (god's truth) became buppō shinri (the truth's of Buddha's teachings). ${ }^{11}$

In the early 1990s, Koffuku no Kagaku also started investing in the promotion of Ōkawa's books in the media. In the period between March and July 1991, Kōfuku no Kagaku financed an advertising campaign entrusted to Dentsū, the advertising and public relations company that promoted Agonshū in the 1980s, as discussed in Chapter Three. Initially, the campaign's goal was publicity for two books published by Kōfuku no Kagaku's publishing house and attributed to the leader Ōkawa Ryūhō (1991a; 1991b), Nosutoradamusu Senritsu no Keiji ("The Terrifying Revelations of Nostradamus”) and Arā no Daikeikoku ("Allah's Great Warning”, Fig. 4.1). Later, the campaign included advertisements for the book Eien no Budda ("The Eternal Buddha", Ōkawa 1991c) and for the Birthday Party (goseitansai) to celebrate Ōkawa's 35th birthday, which took place on July 15, 1991 at the Tokyo Dome in Tokyo, a big complex usually used for sporting events and concerts that can accommodate more than fifty thousand spectators. The large scale of the campaign and its high cost were reported by several newspapers and magazines. According to the Asabi Shinbun, for example, in the one and a half months between May 28 and July 15, the campaign cost 20 billion yen (around $£ 9$ million at the time) and involved four national and thirty-seven regional newspapers-which published the full-page advertisement for the books three times-thirty magazines, various television channels-which broadcasted a fifteen-second commercial 500 times-and thirty-three radio stations (which transmitted the advertisement 200 times). In addition to this, fifty thousand stickers (Fig. 4.1) appeared on taxis all over the country, forty advertising cars were rented and a dirigible flew over Tokyo for a week with the slogan "Now Is the Age of Ko fuku no Kagaku" (Jidai wa ima, Kōfuku no Kagaku, Asahi Shinbun, July 30, 1991, 
29; Berthon 1991, 36). The impressive breadth of the campaign was even compared by journalists to that of the campaigns for American presidential elections (Iwasa 1993, 128-134).

\section{Advertising The Eternal Buddha}

An important characteristic of advertising texts is that the persuasive function is entrusted not only to the image, but also to the language, especially to the slogan or catchphrase destined to imprint itself in consumers' memories and arouse their interest (Baldi et al. 1996, 90-91). Often, as Moeran (1989) also suggests in his analysis of advertising language in Japan, the message is not clearly explicit, but is characterised by an undercurrent of meaning and by an emphasis through association, suggestion and structural incompleteness.

The slogans circulated by Kōfuku no Kagaku in 1991 were used not only for the advertising campaign, but represented the image the group wanted to project of itself in the period preceding the Birthday Festival in July. The recurrent theme in the advertisement texts was an emphasis on the advent of a new era, with expressions such as "Japan's time is coming" (nihon no jidai ga kuru), "An era more extraordinary than the age of Shakyamuni and the age of Jesus is beginning" (Shaka no jidai yori, Iesu no jidai yori, motto sugoi jidai o hajimatteiru) and "You have been waiting for this day since before you were born" (Umareru mae kara kono hi o matteita, Arita 1991, 140-158). The era that is about to arrive is the one indicated in the main slogan used in the campaign ("Now Is the Age of Kōfuku no Kagaku", Fig. 4.2), the time of the Science of Happiness. Consequently, the first impression is that of an emphasis on prophetic tones about an epochal change and the construction of the expectation that something new is about to arrive.

A more detailed analysis of the advertisement text for the book Eien no Budda ("The Eternal Buddha") can illustrate how this atmosphere of expectation and momentousness was created by use of a specific combination of text and images. The book, published in 1991, is presented as a speech by the Buddha, who is bestowing his teachings on humanity. The sentences are rather brief and often end with exhortative or peremptory expressions. After having explained that the Buddha's nature is present in all human beings, lines of conduct are illustrated for changing one's way of living by following Buddhist teachings. Finally, in the last section, followers are urged to spread Buddha's teachings, and his coming is announced.

The advertisement for the book appeared in several newspapers from July $15-19,1991$. While newspaper advertising, which is commonly used to promote new publications by new religions, has the disadvantage that it is not able to guarantee a high graphic quality, it nonetheless offers the opportunity for dissemination on a very large scale. Advertisements in the press also have a series of advantages, including the opportunity to occupy 


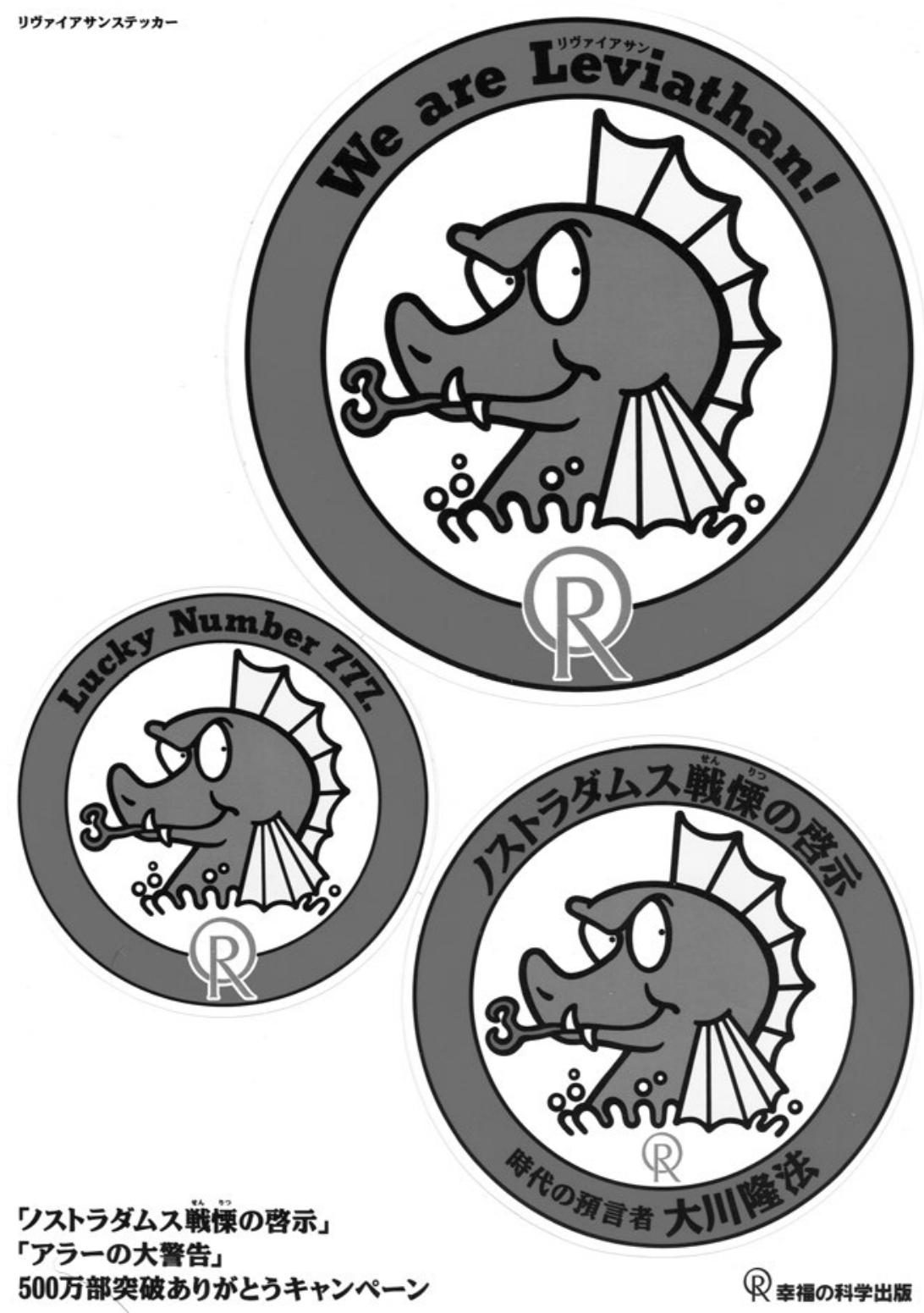

Fig. 4.2 Advertisement stickers distributed by Kōfuku no Kagaku, 1991.

a large space, to be reread and retained (something that is impossible for television commercials) and to be illustrated (unlike radio broadcasts). Furthermore, the medium presupposes an active reception and can be easily transported (Baldi et al. 1996). Kōfuku no Kagaku's advertisement 
covered an entire page, and the central image was a close-up photo of the leader, dressed in a business suit, with a microphone, (supposedly) addressing an audience.

According to a report in the magazine Senden Kaigi, only the Mainichi Shinbun agreed to publish this image, while other newspapers, such as Yomiuri Shinbun, Nikkei Shinbun, Sankei Shinbun and Tokyo Shinbun, requested that the picture should be replaced with an image of the universe and the cover of the book; finally, the Asahi Shinbun only published the cover of the book across half a page ("Kōfuku no Kagaku ..." 1991, 75). Similarly, some newspapers and most TV channels refused to advertise the Birthday Festival ("Kōfuku no Kagaku ...” 1991, 75-78). The reasons for rejecting the images proposed by Kōfuku no Kagaku may be related to both a concern about explicitly supporting the proselytism activities of a new religion and its leader, and different interpretations of guidelines regarding the publication of material related to religious groups for newspapers and television. Television stations tend to follow the Broadcasting Standards (hōsō kijun) set in 1970 by the Japan Commercial Broadcasters Association (Nibon minkan hōso renmei). Item 7 in the standards document is about religion, and it states, "Fundraising, etc., for any particular religion shall not be presented". ${ }^{12}$ On the other hand, newspaper guidelines for religious advertisements vary and they can be interpreted differently on a case-by-case basis: some newspapers who rejected Kōfuku no Kagaku's advertisement for the Birthday Festival, for example, published advertisements for Agonshū's Star Festival. It is possible that the attention from the press that Kōfuku no Kagaku was starting to receive for the advertising campaign and the increase in critical articles about Ōkawa in weekly magazines, paired with the group's eagerness to attract new members, had made newspapers more cautious toward facilitating its proselytism or PR activities. This is an issue that will become more evident during the Kōdansha Friday Affair discussed later in this chapter. The negotiations for the publication of the photograph of the leader was one of the first signs of the tensions between Koffuku no Kagaku and the media that would increase in the following months.

A textual analysis of the advertisement text published in the Mainichi Shinbun (in other words, the original advertisement selected by the group) provides some useful information on how the image of the leader was presented. In the visual framing of the advertisement, the image of the leader is immediately associated with the title of the book (The Eternal Buddha), which appears in white under his photo. The association is reinforced by the body of the advertising text, which claims that "the everlasting light is here now" (fumetsu no hikari, ima koko ni), invites people to "read the light, learn the immense love" (hikari o yomu. Ooinaru ai o shiru) and promises a return to a lost age of love and light:

Sore wa maru de taiyō no yōna hikari ga Anata no mune no tobira o akete, sashikonde kuru kanji 
Ima made yami ni tozasarete ita kokoro ga

Kumanaku akaruku terasareru kankaku

Sono toki, haruka mukashi ni wasuresatte ita

Ano natsukashii kandō ga

Anata no kokoro ippai ni

Afurekuru koto deshō.

(The sensation that a light, like that of the sun/opening the door to your heart, enters you/ and the perception that your heart that was until now enclosed in the darkness/is brightly lit in every corner/ and a nostalgic emotion that was completely forgotten long, long ago, will completely fill your heart.)

The nostalgic feeling is the desire for a past-that is, the feeling of nostalgia of something precious that resurfaces in the memory and that is contained in the semantic field of the term natsukashii. The lamented past is the source of lost values that people, obscured in the shadows, do not know anymore. Memory is connected to the light, hikari, which appears in the title, the subtitle and the first line of the advertisement. The second, fourth and sixth lines are constructed in such a way that they include a term related to the semantic field of memory and feeling: kanji-kankaku and kandō create a rising climax, from a vague feeling to a "sensation" to a "being in (com) motion" that pulls the reader to the exhortative conclusion. The readerthe receiver of the message-through the exhortative conclusion and the repeated use of "anata" (you) is continually drawn into the message. S/he is turned to directly, and exhorted to carry out this change, which in reality is none other than a return to a forgotten state of well-being-to an age where the light shines. The light is the object of remembrance. According to the title, however, the everlasting light is already here (ima koko ni), so the change is about to happen-it is very near. The everlasting light is here, but in the here given by the textual space, there is (a picture of) Ōkawa; thus, Ōkawa is the light. Ōkawa becomes, moreover, the medium of connection with the mythic past evoked by nostalgia, a feeling that has a precise meaning in the advertisements:

The seemingly dysphoric connotation of a passion like nostalgia renders problematic its presence in advertising. The nostalgic theme is found in one layer of separation from its object of value, and recalls the time in which it was connected to it. In order for nostalgia to 'enter' the advertising discourse it is necessary that the reconnection with the object be a reality that is at least possible.

(Melchiorri 2002, 118. My translation)

A text, an image, possesses innumerable possible meanings, and a fundamental role is held by what Eco (1979) calls the "interpretative cooperation" of the receiver, who will privilege a particular representation over 
another according to his or her worldview (Semprini 1997). A straightforward interpretation of the "persuasive communication" (Trotta 2002, 117) promoted by Kôfuku no Kagaku in this campaign will see the group inviting readers to buy a book published by the leader. However, a more careful analysis of the text shows how the goal of the advertising language is not just to attract new "clients" or "readers", but also to involve them in the group's project-to make them become "members". The aim is, therefore, not only the sale of a product, but also the activation of a way of thinking, a "creating of desire" (Ferraro 1999, 82), while at the same time reinforcing the importance placed by the group on Ōkawa's publications. Indeed, the advertisement invites people to "read the light", confirming the central practice of reading and studying leader's writings: according to Shimada, the catchphrase yomeba wakaru, "if you read you will understand", was often used by Kōfuku no Kagaku representatives in response to questions about the group $(1995,93)$. In the period under consideration, the group was undergoing a transition towards a clearer religious identity and needed to legitimise its leader's authority and to create its own tradition. The campaign was organised, therefore, as a sort of advent of the epochal change about to occur due to the actions of a "deity" who had descended to earth to carry out his mission of spreading his teachings to as many people as possible. From this point of view, it can be deduced that the declaration of his identity as the Buddha and El Cantāre that Ōkawa would pronounce at the great Tokyo Dome event was actually already implicit in the advertising message used in the campaign preparatory to the event. From this perspective, the advertising campaign becomes the "annunciation" of the Birthday Festival that was presented in the advertising as "the day in which the Tokyo Dome will become heaven" (sono hi domu tenjokai to naru).

\section{JULY 15, 1991: THE “SACRALISATION” OF THE LEADER}

The birthday celebration (goseitansai) of July 15, 1991 to celebrate Ōkawa's thirty-fifth birthday with an audience of thousands of participants marked a fundamental passage in the group's history. For this reason, it needs to be discussed closely. This was not the first public appearance of the leader (as previously mentioned, public lectures started already in 1987), but it was the first that would be instituted as a festivity that would be repeated every year-together with the El Cantāre Festival in December-and that is related to a personal event in the leader's life: his birthday. A central element in the analysis of the event is the leader's image, which, as already emphasised in the analysis of the advertising text, gradually increased his central role. Ōkawa became not only the principal reference point of the group, but also the figure that all members should emulate. 
The event was simultaneously a birthday party, a spectacular event to celebrate the group's success, a religious ceremony for the announcement of Ōkawa's true identity (shōtai) as El Cantāre and finally, a rite of passage for both the leader and its members into a new phase of the group's development. Indeed, the ceremony sanctioned the sacralisation of the leader's body, through a process of transformation of the body itself, in order to arrive at the final announcement that would decree what Astley defined as the passage "from spiritual medium to the Buddha" $(1995,360)$. The space of the Tokyo Dome became the space where the rite of passage was performed and the image of the leader was transformed into a new role. The leader's body was also turned into a spectacle to captivate the audience and became, paraphrasing Boni (2002), a sort of "consumer product" that was offered to the followers through marketing strategies.

The group also used its high-profile members to attract an audience to the event. Indeed, the script for the festival (also known as "Ōkawa Ryūhō in Tokyo Dome" or "7.15 Tokyo Dome") was written by Kageyama Tamio, a novelist and member of Koffuku no Kagaku, and presented by the famous actress Ogawa Tomoko, who was also a member. At the centre of the stage was a very large photograph of Ōkawa (Nijū Isseiki 1991, 97). The first part of the event was a celebration of the success attained by the group. After the announcement by Ogawa that the event would become a legend that would continue to be told for hundreds and thousands of years (Shükan Gendai, August 3 1991, 46-49), a procession of more than 700 members representing the different branches around the country, called "shishifunjin bosatsu" (lion-like Bodhisattvas, Astley 1995, 361), marched on stage. Each of them was said to have converted over 100 people (Shükan Gendai, August 3 1991, 46-49; Astley 1995, 361; Egawa 1991b). The march was followed by the announcement of membership figures achieved by July 7 th (the actual day of the leader's birthday): $1,527,278$ ! which provoked an eruption of thunderous applause and shouts of joy from the audience. The chanting of the main prayer of Kōfuku no Kagaku, the Dharma of the Right Mind (shōshin hōgo), introduced the second part of the event, when the leader arrived to give his announcement. Ōkawa's entry, recalling the stairway descent of celebrities, was sarcastically described in the press media, such as, for example, in the magazine Friday:

Afterwards, in a swirl of laser beams of a thousand colours, the stars in heaven were reflected on the roof of the Dome. The front of the stage was enveloped in smoke and in the middle of a bluish light appeared a plump figure. Finally the entrance on stage of the founder. Ōkawa slowly descended the white staircase, like the one used in Takarazuka. ${ }^{13}$

(Friday, 31, August 2, 1991, 22. My translation)

Ōkawa, dressed in a blue business suit, addressed the audience with theatrical postures and gestures, his tone of voice resounding and majestic. He 
raised his arms to the sky and declared his "Proclamation of El Cantāre" (Eru kantāre sengen, Ōkawa 1994, 14):

Anatagata no mae ni tachitaru wa,

Ōkawa Ryūhō de atte,

Ōkawa Ryūhō de wa nai.

Anatagata no mae ni tachi,

eien no shinri o kataru wa,

eru kantāre de aru.

Ware wa, kono chikyū no saikō no kengen wo nigiritaru mono de aru.

Ware wa, kono chikyū no hajime yori owari made

subete no kengen o aru mono de aru.

Naze naraba,

ware wa, ningen de wa naku,

hō sono mono de ari kara da.

(Ōkawa 1994, 16-17)

[The one who stands before you is Ōkawa Ryūhō, yet it is not Ōkawa Ryūhō. The one who stands before you and speaks the eternal God's Truth is El Cantare. It is I who possess the highest authority on earth. It is I who have all authority from the beginning of the earth until the end. For I am not human, but the Law itself] (translated in Astley 1995, 360).

Ōkawa had already professed before that he was the Buddha, in a text published in 1989 and entitled, Budda saitan ("The Rebirth of Buddha", Nijü Isseiki 1991, 98), but the declaration during the Birthday Festival was the first public announcement of his true identity as the Greatest Spirit of the Terrestrial Spirit Group, El Cantāre. Therefore, the spectacular event became a ceremony and at the same time a performance,${ }^{14}$ concluding the path of what might be called the "coronation" 15 of the charismatic leader. In another event that started in December of the same year and is called the El Cantāre Festival (Eru kantāresai), the coronation would actually be completed by the leader appearing on stage with a gold robe, a golden sceptre in his hand and a golden crown adorning his head (Astley 1995, 362). ${ }^{16}$ In order to claim his legitimacy as a religious leader, Ōkawa had to appeal to an established and legitimised tradition. Therefore, he declared himself the Buddha before introducing a new original deity, one that is considered both a continuity with an established religious tradition and a superior stage to other teachings. The Buddha announced in the advertising campaign was now manifest, and the first proof of his authority was founded on the fulfilment of the prophecy regarding the increase of followers. The spectacle emotionally connected the members (who are addressed as "angels of light", bikari no tenshi) to the leader and his project. Indeed, during the Birthday Festival, Ōkawa also announced the plan of converting all Japanese people to Kōfuku no Kagaku (zenkokumin kaiin ka senden, Nijū Isseiki 1991, 99) and invested the participants with the task of being messengers of the 


\section{Mediating the Leader's Image}

"light" (hikari). By participating in the ceremony, the followers became part of the event itself and the spectacle created a strong sense of community: the breadth and enthusiasm of the audience became the reconfirmation of its fidelity to the leader. The role of participants was not only to witness the epochal event; they also performed a participatory and emotional role. Ōkawa's proof of his capability as a "great man" (Pace 1986) was confirmed by the ability to attract crowds and to arouse them. His figure, now sacralised, became the centre of the group's practice. The following year, the gohonzon, a picture of Ōkawa with the inscriptions "Shaka Dainyorai" ("Great Buddha") and "Kōfuku no Kagaku" (Astley 1995, 346), was introduced as main object of worship. Gohonzon refers both to the main figure of worship (that is, El Cantāre) and to the main object of worship used during practice, such as, for example, an icon or statue symbolising one aspect of El Cantāre. One example of this is a photograph of the leader with a list of names below it indicating his previous manifestations (such as El Cantāre, Hermes, Buddha, $\mathrm{La} \mathrm{Mu}$, a king of the legendary continent of $\mathrm{Mu}$, and Thos, a king of the mythical contient of Atlantis) that is also used on the altars at the centres.

Some newspapers collected testimonies of members who apparently disagreed with the changes in the organisation (Hayakawa 1991b, 64-65), but for Kōfuku no Kagaku and its leader, the year 1991 is still considered a crucial moment in the history of the group, as is demonstrated in various videos created by Kōfuku no Kagaku and as has been confirmed in my various conversations with members over the years.

So far, the event has been considered as similar to a rite of passage or a ceremony, but the use of the media in the event itself has not been yet discussed. The event did not take place in a television studio and was not initiated by television channels or other media enterprises. Therefore, it was organised outside of the mass media. However, the advertising campaign analysed above played a crucial role in preparing the audience for the event and for Ōkawa's declaration. Furthermore, similarly to Agonshū's events discussed in Chapter Three, the ceremony was broadcast live at Kōfuku no Kagaku branches around the country. In this way, the audience was enlarged to include all the members who could not physically be present in Tokyo. Furthermore, the event was recorded and distributed by Kōfuku no Kagaku's publishing house on videocassettes. Therefore, the lack of repeatability that characterises traditional ritual ceremonies has been replaced by reproducibility, in which special and temporal ways of fruition are dilated. The video can be seen in different places from where it was performed, and even years later. The ritual continues to be performed every time the video is seen, becoming a sort of testimony for followers, who, by viewing it, are able to re-enact the experience of being there and being able to remember a defining moment in the history of their organisation. Finally, because of its visibility, Kōfuku no Kagaku was in the media spotlight and its activities were under intense scrutiny. The Birthday Festival attracted press attention, 
and sarcastic reports about the grandeur of the event were published, along with criticism regarding the movement's finances and Ōkawa's legitimacy as a religious leader. It is on the consequences of this increased public attention that the following sections will focus.

\section{THE KŌDANSHA FRIDAY AFFAIR: THE “DESECRATION” OF THE LEADER}

The process of the "divination", or making sacred of the leader's body by creating a spectacle of it, could be connected to what the sociologist Erving Goffman, in his study of symbolic interaction (Goffman 1961), defines as a front stage and backstage. The front stage is the public performance, the spectacle staged by the leader and his powerful motivational speeches, while the backstage is what takes place behind the scenes. Everything that remains behind the performance, from rehearsals to the leader's private life, must not be visible because it could damage the image of spontaneity and the leader's credibility. This separation between front stage and backstage is essential when performing roles principally based on mystification and on an aura of greatness. However, the leader's media exposure could lead to very different outcomes. On the one hand, it can be useful to disseminate the leader's teachings, increase his/her visibility and project an image of a powerful and large organisation. On the other hand, it could achieve the opposite effect, making the leader exposed to attacks and therefore weaker:

[...] as a spectacular celebrity 'sold' to his audience, the leader is more and more vulnerable, and his legitimisation ever more fragile. Nor does the construction of a politician as a media celebrity (in television and newspapers) signify a restoration of the aura of sanctity of a star: the television personality is one about whom everything is known, whose private life is dug up by reporters just like the wrinkles of his skin by the lens of the photographic and television cameras; and the same applies for the political leader, and naturally for his body.

(Boni 2002, 37-38. My translation.)

This undifferentiated and intimate scrutiny could cause the loss of aura of the leader and the decline of his/her authority (Meyrowitz 1985, 167) from the moment in which s/he is scrutinised by the camera-an aura that was based on the distance between him/her and the audience and that disappears following the staging of the backstage region. In Ōkawa's case, we can understand the backstage region as his private life, which in the early years of the group's development was completely safeguarded and separate from his public image. However, the considerable expense incurred for the advertising campaign, the extravagant Birthday Festival, as well as the (at least 
perceived) rapid increase in followers (coupled with the leader's announcement of his plan to convert the entire nation), attracted the attention and criticism of the press media, in particular, the tabloids. Between the second half of 1991 and the beginning of 1992, a series of satirical publications also appeared, such as the book co-authored by Yonemoto Kazuhiro and Shimada Hiromi that presents a parody of Ōkawa's reigen (Yonemoto and Shimada 1992; see also Yakushi' in 1991). Numerous newspapers and magazines published articles attacking or ridiculing the group. In the second half of 1991, the magazines Friday, Shükan Gendai and Gekkan Gendai published more than 40 articles over three months on Ōkawa and Kōfuku no Kagaku (Fukui 2004, 75). Some of the articles, using tones similar to those used for celebrities involved in scandals, focused their criticism principally on the supposedly large donations that members were required to make to finance the advertising campaign and the Birthday Festival, and accused the group of resembling a business more than a religious group (see, for example, Gekkan Asahi, May 1991; Sukora, May 23, 1991; Shinchō, 45, September 1991).

An article that appeared on August 3,1991 in Shükan Gendai, for example, reported alleged testimonies from members denouncing how local branches were forced to raise large sums of money to support the Birthday Festival or how they were asked to sell hundreds of tickets (Shükan Gendai, 48). It also included the testimonies of distressed family members whose siblings had donated their belongings to the group. These accusations, which follow recurrent patterns used in critical reporting of new religions both in Japan and elsewhere (especially regarding large donations and worried family members), attacked mostly the external aspects of the organisation, such as its organisational structure and its finances. However, attention also turned to the leader himself, and it was a series of articles attacking the leader and his privacy that aroused a vigorous reaction by the group and led to the Kōdansha Friday Affair in September 1991. In particular, the most controversial article was published in the weekly Friday on August 23/30, 1991 (Hayakawa 1991a). The article aimed to expose the "other side" (uragawa) of the ambitious leader Ōkawa, who claimed to be the Buddha, and of the greedy group that was labelled a "bubble religious group" (baboru kyōdan). The article reports an alleged testimony by Ishihara Tsuneji, a former officer of the new religion GLA, according to whom Ōkawa, when he was still a company employee, went to see him under a false name for a consultation about his obsessions:

He came to consult with me about a neurosis, saying: 'While I was reading the book Shinsōseiki [True Genesis] by Takahashi Keiko of GLA I felt strange. A fox entered inside me. What should I do?' He [. . . ] was in state of profound depression. [. . .] He also used the name Nakagawa Ichirō.

(Note: his real name is Nakagawa Takashi.) (Hayakawa 1991a, 80. My translation.) 
The profanation of the leader continued with an invasive discussion of his private life in order to depict him as a person who was very ordinary, if not even banal, compared to his autobiographical account, in which the first signs of his special quality and future mission are portrayed as already evident during his childhood. In other articles in the following months, the same journalist, Hayakawa Kazuhiro, reported interviews with former schoolmates from high school and university who expressed their surprise that someone who was a very ordinary young man and student had become a religious leader (Hayakawa 1991b and 1991c).

The denigration of the leader's mind and personality took place next, through an attack on his mental state with morbid details of his presumed consultations with the GLA doctor and with an invasion into emotionally intimate spheres, such as the memories of his childhood and adolescence. In reality, some articles prior to the Birthday Festival event had also made allegations about Ōkawa's mental health, but the danger of these particular accusations was strongly perceived by the group since the attack was directed at the "divine body" of the leader, after his declaration of being the reincarnation of El Cantāre, in an attempt to reduce it to the level of any ordinary man (or worse, of a man who is not sane) and thus to desecrate it. ${ }^{17}$

Hayakawa's article, which was later proved to be based on incorrect information and mistaken identity, triggered a campaign of action that started in September 1991. On September 2, 1991, Kōfuku no Kagaku's followers, led by high-profile members Kageyama Tamio and Ogawa Tomoko, held demonstrations around Tokyo and protested in front of Kōdansha's head office. The event came to be named the Kōdansha Friday Affair (Kōdansha furaidè jiken), referring to the tabloid Friday that was at the centre of the protest (Fukui 2004, 75). The protest campaign consisted of demonstrations, the distribution of pamphlets and, above all, sending hundreds of faxes and telephone calls, blocking Kōdansha's telephone lines and disrupting work for several days (Astley 1995, 370). In an interview with the Mainichi Shinbun, Ōkawa accused Japan of not understanding Kōfuku no Kagaku because it was not used to the experience of revealed religions, but rather to religions based on texts. He appealed to the freedom of religious belief against the criticism in the press, and in answer to the question of why he had gotten angry with Friday in particular, he accused Friday's article of reporting false information:

I have certainly never met that person [He is referring to Ishihara Tsuneji, the one who testified regarding Ōkawa, saying, 'He came for a consultation about neurosis' in the Friday article that became a problem] not even once. Even he himself said, 'I've never met Ōkawa', and he called on the phone to tell me that.

(Sunday Mainichi, 1991, 182. My translation.)

The group's action came as a surprise to the public and the media. Several television debates were devoted to the protest, including interviews with 


\section{6}

members and other involved parties (such as, for example, Ishihara Tsuneji, who declared that his account had been fabricated). Kōfuku no Kagaku therefore received extensive media coverage. During television debates, its actions were described as a way of protesting that had never seen before, and the tabloid's wrongdoings were recognised. However, Kōfuku no Kagaku tended to be portrayed as a very unusual and litigious group. In the following months, reporting about Kōfuku no Kagaku sharply decreased; it looked as if Kōdansha's experience and Kōfuku no Kagaku's aggressive response to criticism had sent a tacit warning to the press media that it was safer not to report about this group.

Members of Kōfuku no Kagaku, including the writer Kageyama Tamio (in the position of director) and the actress Ogawa Tomoko (as assistant director), founded the National Association of the Kōdansha Friday Victims (Kōdansha Furaidē Zenkoku Higaisha no Kai, Numata 1995, 196-197). About three thousand members filed lawsuits against Kōdansha for spiritual damage (seishinteki kōgai soshō, Astley 1995, 371), claiming that the libellous accusations had injured their faith. The association described itself in this way:

The National Association of the Kōdansha Friday Victims is an association of citizens who are victims of the distorted and defamatory articles by the media connected to Kōdansha, including the photographic weekly Friday and others. The association [...] has developed activities to protect faith and human rights from 'violence of the press'.

(Kōdansha Furaidē Zenkoku Higaisha no Kai 1995, 204. My translation.)

The court case that followed the protest lasted for many years. The association published some texts concerning the Ködansha incident, ${ }^{18}$ among which a significant example is given by the comic book Kibō no Kakumei ("The Revolution of Hope,” Kōdansha Furaidē Zenkoku Higaisha no Kai, 1995), from the name used by the group to describe the actions of members protesting against Kōdansha, and which I will outline below to indicate Kōfuku no Kagaku's attitude towards the affair.

\section{Kibō no Kakumei: The Revolution of Hope}

The book is structured in two parts: the first contains a manga that spans four chapters, and the second provides the transcription of a discussion between the director and assistant director of the National Association of the Kōdansha Friday Victims and an account of the legal actions against Kōdansha. The text is presented as the record of the truth (Kōdansha Furaide Zenkoku Higaisha no Kai, hereafter KFZHK 1995, 1) of the people who initiated an organisation against the "violence of the press" (genron no bōryoku, KFZHK 1995, 1) in order to build an ideal society based on spiritual 
values and faith (KFZHK 1995, 1). In the introduction, reference is made to the birth of Lucifer, hell and the struggle between evil and the light of Buddha, which continues to the present day and reaches as far as the third dimension in which we live. In this way, with the image of a city divided in two and contested between evil forces and heavenly ones, the theme that runs through the entire narrative is introduced: the eternal struggle between good and evil.

The ethical connotation that the struggle assumes is included in the first chapter, centred on the personal experience of a group member who was a witness at the trial. The narrative, in fact, following questions from the judiciary, reconstructs his conversion (from the casual reading of one of the leader's books bought in a bookstore to becoming the director of a local branch), trying to emphasise his moral integrity (he refuses to involve his students in the religious group so as not to take advantage of his role as a teacher by influencing them, he helps parents who are in trouble and so on) and the depth of his faith (his proselytising activity), a virtue brusquely wounded by the attacks in the newspaper articles, which caused, more than anything else, according to his words, "damage to his spirit" (kokoro no higai, KFZHK 1995, 35).

In the second chapter, titled "The Evil of Our Time" (Gendai no akuma, KFZHK 1995, 63) appears, embodied in the Kōdansha publishing house, whose story is told. The reconstruction shows the demonic origin of the company's members, who are accused of having sold their souls to the devil and of having violated human rights on several occasions (KFZHK 1995, 68-71), and it draws attention to their amorality. The proof of contact between evil and the group is also given by the sudden deaths of many of the directors of the publishing house. The battle takes place in the third chapter, where the forces of evil, thanks to the press, seem to have the upper hand, but, from Japan, the "light of hope" (kibō no hikari, KFZHK 1995, 131), incarnated in El Cantāre, is radiating. The victory of good leads the members of the group to rise up against the evil Kōdansha publishing house's immorality. The beginning of the dispute and the "revolution of hope" (kibo no kakumei, KFZHK 1995, 139) are related in the fourth chapter.

The moralising tone of the comic book is maintained in the dialogue between the director and assistant director, which focuses mostly on the defence of the "right religion" (tadashii shükyō) destined to "renew the world" (yonaoshi, KFZHK 1995, 155) and on criticism of religion when it is used for mere appearance's sake (for example, the Zen meditation courses organised by Buddhist temples for company employees are criticised as superficial). The proposal put forward is that of a lifestyle of faith that leads to expressing one's faith even in everyday life, in working relationships or in conversation with acquaintances, and implementing a constant activity of proselytism (KFZHK 1995, 155). Through this perspective, the affronts of the newspaper articles are considered offences against faith and thus are the cause of spiritual damage. 


\section{Mediating the Leader's Image}

The conflict between Ōkawa and the publishing house expanded to include not only all his followers, but also all of society disturbed by the conflict between hope and damnation. The protest against the defamatory articles became then a protest against spreading immorality and the victory of the cause, as proof that the "age of religion" (shükyo no jidai) has truly arrived (KFZHK 1995, 189). The text concludes with a detailed account of all the hearings of the proceedings brought in various cities of Japan and with the information necessary to join the group or to receive other materials regarding protests against mass media.

The Kōdansha Friday Affair emerged as a direct attack on the media's power. At the same time, however, the fact that the protest against Kodansha used the media themselves for its diffusion-both with the publications released by the groups and with members' frequent interviews in the press and TV appearances-shows the ambivalent relationship Kōfuku no Kagaku had with the media. In particular, as shown by this manga, Kōfuku no Kagaku used media forms to construct images of "evil" and to attack its enemies in a very similar way (and using similar arguments) to the ways in which journalists had used newspapers and magazines to criticise the group. The construction of the enemy and of "evil" in the group's publications is also evident in its portrayal of other new religions, as will be discussed in the following section.

\section{Beyond the Kōdansha Friday Affair}

Kōfuku no Kagaku's protest against Kōdansha showed the group's ability to mobilise members, who gathered round their leader to safeguard his image, vehemently rejecting his desecration. Through activism, the group strengthened the commitment of some of its members and drew attention to the potential reactions of new religions to criticism. The protest also shows an interesting aspect of the relationship between media and new religions. Media reporting about new religions can strongly impact how a group is perceived by the general public. However, how the mass media are judged by a religious group can strongly impact how members criticise communications media (Stout and Buddenbaum 1996). As illustrated in the previous section, in Kōfuku no Kagaku's publications and in Ōkawa's speeches, the mass media became the manifestation of evil and the group's enemy. In an article published in the magazine Shükan Bunshun, the journalist Egawa Shōko, for example, reported on Ōkawa's public lecture, titled Kibo no kakumei ("The Revolution of Hope", see also Numata 1995, 197-98) at the Yokohama Arena on September 15, 1991, in which he vehemently attached Friday and Kōdansha and invited the members to protest against the "stronghold of the Devil" (akuma no gajō). Egawa describes Ōkawa postures (raising his voice, banging his fists on the table and so on) to emphasise his confrontational attitude and his explicit attacks on the mass media, which cannot be forgiven for their behaviour (Egawa 1991c, 34). 
The protest, however, also owed its incisiveness to the use of the media by the group, and the book that started off the advertising campaign of 1991, Arā no Daikeikoku (“Allah's Great Warning”), already contained vehement attacks against the press. In the text, in fact, trust in articles' contents is defined as "faith towards the mass media" (masukomi shinkō, Ōkawa 1991a, 25) and "Baal worship" (bāru shinkō, Ōkawa 1991a, 25), and the newspapers are accused of being only interested in increasing their readership and of focusing their attention exclusively on the negative aspects of the activities of politicians. In addition, the mass media are accused of altering their opinions to please as many people as possible and of covering topics with too much superficiality and lack of depth.

Following the protest against Friday for reporting defamatory accusations about the leader, Kōfuku no Kagaku was also able to strategically shift the conflict to other topics, in order to potentially attract the interest and support of non-members. Indeed, the Kōdansha Friday Affair would also signal the beginning of Kōfuku no Kagaku's civil—and thus politicalactivity, in particular with a major protest campaign against pornography in the press (Kōfuku no Kagaku Kōhōkyoku 1995). By focusing on topics that offended morality, such as nude images, in the counterattack against Kōdansha, Kōfuku no Kagaku attempted to attract favourable support also from people who might disagree with their methods, but would recognise the reasons for the protest. As mentioned in Chapters One and Two, other new religions had previously been the object of defamatory campaigns and some of them, such as Renmonkyō, reacted by rejecting the accusations and suing the relevant organs of the press. In the case of Renmonkyō, however, the group's defensive reactions resulted in a loss of credibility and eventually resulted in the decline of the organisation. Kōfuku no Kagaku, on the contrary, used the protest to reinforce its image as a powerful and large organisation and to strengthen its missionary plan. However, although the group may have been able to use the protest to reinforce internal cohesion, the Kōdansha Friday Affair created an image of Kōfuku no Kagaku as a litigious group that tried to suppress free speech and discussion. As mentioned before, this resulted in the mass media avoiding reporting about the group, and general public attendance at its public events decreased (Numata 1995, 198). ${ }^{19}$

Kōfuku no Kagaku also replied to print media criticism by assuming the role of protector of public morals and values that the media has at times assumed in Japan. In the period following the Kōdansha affair, for example, the group initiated strong attacks toward other new religions that it accused of being heretical religions (jakyō), notably Aum Shinrikyō and Sōka Gakkai. ${ }^{20}$ The hostile attitude towards other new religions, in particular Aum Shinrikyō, was already present before 1991, as the two groups were often portrayed as rivals, but it intensified in the following years. It is beyond the scope of this book to discuss in detail Kōfuku no Kagaku's debates with other new religions, and some aspects of the rivalry with Aum Shinrikyō have been discussed elsewhere (Baffelli and Reader 2011). However, it is important to 


\section{Mediating the Leader's Image}

note that in its attack on Aum Shinrikyō, Kōfuku no Kagaku used accusations about its leader's past and his physical appearance that were similar to the defamatory reporting that inflamed the protest against Kōdansha. Once again, Kōfuku no Kagaku demonstrated an ambivalent relationship towards the media, which were seen as useful and positive (and could be also used to damage rival groups) when they could be used to the advantage of the group. As already mentioned before, the criticism towards the printed media during the Kōdansha Friday Affair was mainly done through publication of critical books. Since 1992, Kōfuku no Kagaku has been promoting several books that include criticism of the mass media and the press that were paradoxically promoted mainly via advertising in newspapers and that were included in magazines' bestsellers rankings (Yamashita 1997, 68). In reality, therefore, the protest of Koffuku no Kagaku towards the media, more than being a criticism of their persuasive power and their dangerousness, which would conflict with the use that the group itself makes of these strategies, was an efficacious expedient to increase its own popularity, both through the criticism and through the responses obtained during the demonstrations, and also to safeguard the figure of the leader, whose integrity had been threatened by the attacks in the press.

This analysis of the relationship between Kōfuku no Kagaku and the mass media at the beginning of the 1990s has revealed how the combination of effective strategies linked to doctrinal changes and to communication techniques offered by the mass media has determined the success obtained by Ōkawa and his movement. Indeed, even though the data regarding membership are probably inflated, ${ }^{21}$ the sudden increase in the number of followers in a brief period of time and-as numerous articles testify-the great media interest generated by Kōfuku no Kagaku's public events in those years are undeniable.

The key to this success could be ascribed to the choice of a malleable, not rigidly fixed doctrine that allowed the group to adapt to the requirements of contemporary society by proposing a path to salvation realisable in daily life, in relationships with friends or in the workplace. The way of presenting the teachings also played an important role by adapting the message to advertising language, emphasising the leader's visibility and by exploiting mediation practices to spread his teachings.

The representation of a charismatic leader as a deity is not new in the context of Japanese new religions. Divine powers are at times attributed to founders and leaders to legitimate their authority and enhance their messages. ${ }^{22}$ Ōkawa's distinctiveness lies rather in his mode of interacting with his followers and in the creation of an image of a leader that becomes credible to them through showing himself in public and through the amplification of his message in the media. The more the message is spread, the more visible the leader will be and the more he will attract new followers, and success in membership thus becomes a validation of the leader's prophecies and of his authority. 
In order to maintain authority, however, stability is needed, and so the leader must abandon his spontaneity, creating an image in which every movement and every word are controlled and measured in order to appear as model of perfection. The final development will be the abandonment of the body - the creation of an immaterial and virtual leader. Indeed, from 1995 until 2008, Ōkawa decided to retire from the scene and communicate with members mainly through videos.

\section{KŌFUKU NO KAGAKU POST-1995: THE VIRTUAL LEADER AND HIS RETURN}

The main aim of this chapter has been to analyse Kōfuku no Kagaku's mediation practices and conflict with press media in early 1990s. However, I would like to provide some final comments about later developments in the image strategies of the group, in particular regarding the leader's image and use of the Internet.

In 1994, Kōfuku no Kagaku launched a "Big Bang Project" (biggu bangu keikaku, Numata 1995, 201), which included a full-scale programme of missionary work and overseas expansion. In 1995, Kōfuku no Kagaku immediately distanced itself from Aum Shinrikyō, publicly denouncing the group and emphasising the fact that it had previously alerted authorities regarding Aum's misconduct. However, as discussed in Chapter One, new religions and their leaders in general came under strict scrutiny after the sarin gas attacks. Kōfuku no Kagaku was also still recovering from the media exposure during the Kōdansha Friday Affair and had a reputation of engaging in aggressive activism. Therefore, the group was forced to reconsider its image strategies. In 1996, the group stopped holding large events at the Tokyo Dome, and instead, festivals started to be held at local branches (where, obviously, the access of external media was more controlled). Until 2008, Ōkawa communicated with followers mainly via his publications and videos that were showed during ceremonies and training meetings. The settings used in the videos were very similar. The leader generally appears behind a desk or a lectern and speaks through a microphone, the neutral background showing only the symbol of the group. Therefore, the direct contact with the members, which was essential in early stage of formation of the group, was replaced by his mediated image, despite his being still alive and of a young age. According to interviews with members I had before 2008, the main reason for the limited interactions between the leader and members was the amount of energy required for these interactions and for public performances. However, I would suggest that the leader's choice was also connect to image strategies implemented after 1995. By withdrawing from personal contact with members and by romanticising his own biography, Ōkawa's "backstage region", which was attacked during the Kōdansha Friday Affair, remained strictly under the control of the group's leadership. Ōkawa was 


\section{Mediating the Leader's Image}

perceived as untouchable, distant to the point where his body became "virtualised" (Boni 2002). In this virtualisation, the charismatic authority emerging from the direct contact between the leader and his followers was undermined, and this despite the fact that the leader was still alive. At the same time, his figure became immaterial, semi-divine, only occasionally manifesting itself in a physical sense. The leader's choice to reduce public appearances can thus be turned into an effective means of avoiding criticism and maintaining his authority and legitimacy as a spiritual guide. Indeed, an idealised image controlled by the group may weaken direct bonds; however, at the same time, it can lead to the creation of a more stable public image.

Kōfuku no Kagaku's communication strategies also impacted its use of the Internet. The group established its Internet presence comparatively late and its official website appeared online only in December 2004 (although a website for its publishing house was already established in 1999, Staemmler 2000; Baffelli 2000; 2010). Compared to its relatively aggressive use of other media (first and foremost the press), its use of the Internet until a few years ago has been relatively modest, both in terms of presence and interactivity. After 2004, however, the group has been strongly increasing its Internet presence with the creation of several new websites, including one devoted to its new political party, Kōfuku Jitsugentō (Happiness Realisation Party), which was established in 2009, promotional websites for the group's movies, websites devoted to specific magazines and a website for the radio programme Tenshi no mōningu call ("Angel's Morning Call”) (Baffelli 2011). Kōfuku no Kagaku has also been using new forms of communication such as podcasts, member-only websites, blogs, social media, such as Twitter and Facebook, videos on YouTube, online television and so on.

Ōkawa Ryūhō reappeared on the scene in 2008 and started performing public events and lectures again. Until the first half of 2009, images of the leader online were sparse and only a very few pictures were reproduced on all of Kōfuku no Kagaku's websites. Just before the 2009 general national election, however, Ōkawa suddenly declared that he was the new party leader and that he was going to run for election. As a consequence, an increasing quantity of advertising materials for the party (booklets, posters, video ads) started to be posted on the web, in particular on the party's official website and on YouTube. Furthermore, a website devoted to Ōkawa Ryūhō was created, which included his profile, activities and videos. Despite the significant presence of Ōkawa on the web, however, his image is still strictly controlled. The leader doesn't engage in interaction with members online, and his authoritative role and superiority are made clear and reinforced by his virtual representations.

A more recent development was mentioned during a series of conversations and interviews I conducted with Kōfuku no Kagaku representatives and members in July 2014. During our conversations, the members pointed out that when they initially joined the group, it was easier to meet the leader directly and, when possible, they still travel to see him at public events. 
Apparently, the members' need to have direct encounters with the leader has been considered by the organisation and Ōkawa has recently started to have small, informal meetings, especially with new members. This new development would require further investigation, but it seems to suggest that, despite the leader being made present to members via videos of his speeches and spiritual messages (which also restarted in 2009), publications of his writing and spiritual connections through prayers, the mediated image may not be sufficient and a reinforcement of direct contact with members may be necessary in a period in which Kōfuku no Kagaku, as with other new religions, may be facing the challenge of stagnant growth and an ageing membership.

\section{NOTES}

1. Until 2008, in English, the group used the name "The Institute for Research in Human Happiness".

2. Accounts on Ōkawa Ryūhō and Kōfuku no Kagaku can be found in Arita (1991); Astley (1995); Baffelli (2005; 2011); Berthon (1991); Fukui (1999; 2004); Nijū Isseiki (1991); Shimada (1992); Wieczorek (2002); Winter (2012); Yonemoto (1990); Yonemoto and Shimada (1992).

3. The term "Good News" (ii shirase) is explained by the leader as equivalent to the Gospel in Christianity (Ōkawa 2001a, 174).

4. Nichiren is a thirteenth-century Japanese Buddhist monk whose teachings focused on the Lotus Sutra (bokkekyō in Japanese) and influenced several new Buddhist movements founded in the twentieth century, such as Risshō Kōseikai and Sōka Gakkai.

5. In the pre-1991 version of the same text, The Laws of the Sun, Takahashi said to Ōkawa that he had to "teach the laws of salvation to save humankind" (Ōkawa 1987, 235; Ōkawa 1990c, 209). The recognition as the "rebirth of [the] Buddha" was modified in the post-1991 edition of the book.

6. For example, in conversations I had with members during interviews or at the group's larger gatherings, The Laws of the Sun were often mentioned by members as their first encounter with Ōkawa's teachings.

7. The cosmology of Kôfuku no Kagaku was largely influenced by the GLA's doctrine. For a detailed explanation about cosmology, see Fukui (2004, 103-107); Nijū Isseiki (1991); Numata (1995).

8. According to explanations in Kōfuku no Kagaku's publications and websites, "El" means "light" and "Cantāre" means "land or earth". Therefore, the name of the deity means "the beautiful land of light, earth" (uruwashiki hikari no kuni, chikyū).

9. For a detailed explanation of the Principle of Happiness, see Astley (1995, 366); Nijū Isseiki (1991, 132-140).

10. According to the group, in 2011, Ōkawa entered the Guinness World Records as "the most books written in a year by an individual", having published 52 books in 2010. See: http://happy-science.org/ryuho-okawa/ Accessed July 15, 2015.

11. The same changes are noticeable in the English version of the book. The 1990 edition uses the term "God's Truth", while in 1997, it changed to "Buddha's Truth”. (Ōkawa 1990c, 7; Ōkawa 2001a,11). The text has also been published as a manga in six volumes (one for each chapter), illustrated by Hashimoto Kazunori. 


\section{Mediating the Leader's Image}

12. For a complete document, see: http://www.j-ba.or.jp/category/english/jba101019. Accessed July 22, 2015.

13. Takarazuka is an all-female musical theatre in the city of Takarazuka, Hyōgo Prefecture, that is famous for its extravagant musical productions.

14. In the sense derived from the Old French word, performance: "complete", "carry to an end".

15. According to Dayan and Katz (1992), the coronation represents the celebration of the investiture and recognition of the extraordinary charisma of the hero.

16. See also the video Shinseikai kensetsu ("Establishing a New World") with the recording of the event distributed by Kōfuku no Kagaku's publishing house, Kōfuku no Kagaku Shuppan.

17. Boni speaks of dethronement, "like all those ceremonies of delegitimization that consist of rituals of degradation (Garfinkel 1955) and that at the time of their television representation (and also of their coverage through the press, which produces the most intimate details and particulars, taken from stills from the television filming) the physical details of the leader are especially toyed with, caught during moments of weakness, of anxiety, of tension and fear, on which the moral sanction of the spectators inevitably tends to be formulated" (Boni 2002, 53. My translation.).

18. The list of texts published in the comic book Kibo no Kakumei is the following: Kageyama Tamio, Ogawa Tomoko eds. Shūkyō no Hangeki ("Religion's Counterattack", 1993) provides details on the Friday case and the trial; Kōdansha Furaidē Zenkoku Higaisha no Kai ed. Kōdansha Bōkokuron (Kōdansha Ruin of the Country 1994); Kōfuku no Kagaku Kōhōkyoku, Sutoppu za Hea Nüdo. Anata no Kodomo Ga, Abunai! (Stop Uncensored Nudes! Your Children are in Danger! 1995) offers details on the violation by the weeklies of the law regarding the publication of uncensored nudes images; Kōfuku no Kagaku Kōhōkyoku, Genron jiyū VS shinkyō jiȳu. (Freedom of Speech VS Freedom of Religion 1995). In addition, references to events appeared in many other texts published by the group, such as, for example, in Chapter 3 of the text Manga de Miru Kōfuku no Kagaku, which is discussed in Chapter Two of this volume.

19. Kōfuku no Kagaku is still accusing the mass media of ignoring them nowadays. In particular, the failure of its political party at the parliamentary elections in 2009 and 2010 has been attributed to media ostracism toward the group. As pointed out by Reader (2000a, 156) Aum Shinrikyō also blamed the media for their political party's defeat during the Lower House Elections in 1990.

20. From 1994, several books attacking Sōka Gakkai were published, such as Einen no Chōsen ("The Eternal Challenge", 1995), Sōkagakkai Bōkokuron ("Sōkagakkai Ruin of The Country", 1995), Sōkagakkai Makeinuron ("Sōkagakkai the Dejected Loser", 1995) and Sōkagakkai Dorakyuraron ("Sōkagakkai-Dracula", 1995).

21. The figure of 5.5 million followers indicated by the group in 1992 was also considered unlikely by Astley $(1995,352)$.

22. Worth mentioning, for example, is Konkō Daijin of Konkōkyō, called Ikigami, "living kami”, Naganuma Myōkō of Risshō Kōseikai, to her followers Ikibotoke, "living Buddha" and Nakayama Miki of Tenrikyō considered the "parent of all humanity", Oyasama. 


\title{
5 New Religions and Offline/ Online Interactions
}

\author{
Aum Shinrikyō, Hikari no Wa \\ and the Internet
}

As discussed in Chapter One, Japanese new religions have been latecomers to the Internet, and the content of their websites is often limited to providing information and materials replicated from other publications, such as magazines and newspapers (Baffelli 2011; Kawabata and Tamura 2007). ${ }^{1}$ This cautious approach to new media was due to a combination of internal and external factors, as has already been discussed in the cases of Agonshū and Kōfuku no Kagaku. For example, some movements tend to be more conservative in exploring new media technologies at later stages of their development and prefer to continue using image strategies that have been previously successful.

Furthermore, the interactive features of the Internet require a staff able to engage in direct communication with members, but the leader and the organisation management may be less familiar with new technologies than younger generation of members (who, however, often don't have the authority to make decisions). Also, leaders may be used to interacting with members face-to-face or during larger events, but less inclined to engage in online interactions, something that can also be rather time consuming. Regarding external factors, being a relatively open-structured environment where potentially anybody could express their own opinion makes the Internet very difficult to control effectively in case of defamatory attacks toward the movement. Fukamizu (2011) and Tamura and Tamura (2011) discuss, for example, how a traditional Buddhist sect, the Jōdo Shinshū Honganjiha, or True Pure Land Honganji, and Sōka Gakkai respectively received severe criticism online and attacks by other religious organisations, notably with regard to attacks by the new religion Shinrankai ${ }^{2}$ on the Jōdo Shinshū Buddhist sect, and how they reacted to it. Online attacks, and the difficulty of controlling them, were certainly a matter of concern for new religions immediately after 1995, and they are still a central issue for a group's reputation nowadays. ${ }^{3}$

This does not mean that all new religions avoid the Internet or only use it to post general information. In recent years, for example, also due to the diffusion of the Internet and the popularity of social media in Japan, ${ }^{4}$ several new religions have created elaborate websites, and communities of 


\section{New Religions and Offline/Online Interactions}

members or groups managed directly by organisations have increased on social media such as Mixi and Facebook. Some movements and their leaders have also engaged with the interactive features offered by online platforms. For example, Taniguchi Masanobu (1951-), president of Seichō no Ie, writes his own $\operatorname{blog}^{5}$ and has been actively using social media, in particular Facebook $^{6}$ (Giambra 2015, 179-180) and Twitter, to promote his lectures and also to involve his readers by talking about his hobbies and daily life activities (such as preparing jam with his wife or watching tadpoles in the pond in his garden). There are also a few examples of social media created by new religions in order to connect members, such as, for example, Tsunagaru Young Buddha, a social media site created in 2008 (now discontinued) by Koffuku no Kagaku and linked to the website of a magazine published by the group for younger members and titled Young Buddha, or PostingJoy, a social networking site created by Seichō no Ie and available in Japanese, English and Portuguese (Giambra 2015, 180).

There are also some cases where using the Internet has become a major focus of activities, especially when other circumstances make it harder for such groups to operate or proselytise in other ways. This is the case with Aum, the group responsible, among other crimes, for the sarin gas attack in the Tokyo subway, and in particular for its splinter group Hikari no Wa, which remains suspect in Japan because of its former connections with Aum and which is under constant surveillance by the police and related authorities. ${ }^{7}$

It is these groups I will especially focus on in this chapter. The aim of this chapter is to investigate how online representations can potentially impact how religious groups and their leaders are portrayed and understood, and how online interactions can potentially reshape the relationship between leaders and members. I also argue that online representation reflects how leaders are represented in other media and that specific circumstances affect what types of media technologies new religions will employ to spread their teaching or attempt to improve their reputation.

In order to investigate the use of the Internet by Hikari no Wa, my collection of online materials (websites, discussions on social media, online videos and so on) was integrated with interviews during several visits to Japan between January 2009 and July 2014 with Hikari no Wa's public relation representatives, its webmaster and its leader, ${ }^{8}$ Joyū Fumihiro. The interviews were conducted in Japanese and took place at the group's headquarters in Tokyo and lasted for one to three hours. The interviews covered three key areas: Internet use and Hikari no Wa (its official website, its YouTube channel and Ustream), the group's future projects and visions (the idea of "Net Dōjō", an online "training hall" to allow potential members to engage with the group within the privacy of their houses, which I will discuss later) and leader-members interactions online (via Twitter, Mixi, blogs and the development of off kai, offline meetings).

From 2008 to 2015, I have followed Hikari no Wa's use of the Internet and interactions between members and non-members in social media 
by following Jōyū's Mixi and Twitter ${ }^{9}$ accounts and members' interactions and discussions on Mixi. Furthermore, I have gained access to their online public talks and online yoga practices. Between November 2010 and January 2011, I also participated in a three-day pilgrimage organised by the group and attended seminars, meetings and public events. By focusing on leader-members and members-members interactions during my fieldwork in Japan, I gained greater insights into the effects of online interactions on the group's internal relationships. In particular, I was able to follow the development of the Net Dōjō and the beginning of off kai (literally, offline meetings), meetings between Hikari no Wa's members and users who have been in contact with them through Mixi or Twitter.

Before focusing on the analysis of the use of Internet by Hikari no Wa, however, a short introduction of Aum Shinrikyō, the most notorious Japanese new religion, along with Hikari no Wa's development as an offshoot of Aum, is necessary.

\section{ASAHARA SHŌKŌ AND AUM SHINRIKYŌ'10}

Asahara Shōkō was born Matsumoto Chizuo on March 2, 1955 on the southern island of Kyushu. ${ }^{11}$ Asahara was born partially blind and he was sent to a special boarding school from the age of six. In 1975, after graduating from high school, he studied massage, acupuncture and moxibustion. In 1977, he moved to Tōkyō hoping to enter the University of Tokyo, but he failed the entry examination. In 1978, he married Ishii Tomoko (b. 1958)they were to have two sons and four daughters-and opened a Chinese medicine business in Funabashi in Chiba Prefecture. Between 1980 and 1984, Asahara for some time became a member of Agonshū. ${ }^{12}$ In 1983, Asahara opened a yoga school in Shibuya, Tokyo, and in 1984 founded a group first named Aum no Kai, then Aum Shinsen no Kai and eventually, since 1987, Aum Shinrikyō. Aum Shinrikyō was granted the status of a religious corporation under the Religious Juridical Persons Law (Shūkyō Hōjin Hō) in August 1989. In 1986, Asahara with some of his followers travelled to India for religious exercises where, according to his account, he achieved enlightenment. The same year, he published his first book, Chōnōryoku: Himitsu no kaihatsuhō ("The Secret to Developing Supernatural Powers"). In 1987, he met the 14th Dalai Lama, Tenzin Gyatso (b. 1935), and reported that the Dalai Lama had sent him to revive Buddhism in Japan. In 1986, a double system of membership was introduced with lay members who took part in activities on a more or less regular scale and shukkesha (literally "person who left his/her house", a term used in Buddhism to indicate renunciants), members who had "left the world", cutting their ties with their families and friends, leaving their jobs or schools and starting a communal life with other members (Reader 2000a, 8). The number of members increased rapidly during the first few years of the activities of the group. In 1989, 


\section{New Religions and Offline/Online Interactions}

Aum Shinrikyō reached around 4,000 members, 380 of them shukkesha. In 1995, the group claimed around 10,000 members in Japan (Reader 2000a, 63). Among them, around 1,100 lived in communes. Many Aum Shinrikyō members were young, 47.5 per cent in their twenties and 75.4 per cent in their twenties and thirties (Shimazono 2001b, 21). The average age of the shukkesha was 30.1 years. Many members were very well educated, having graduated from high-ranking universities. Aum Shinrikyō was based on a rigid hierarchical structure, including ten ranks for shukkesha and, below them, ordinary lay members (Reader 2000a, 86). At the top of the hierarchy was Asahara himself, who was referred to as the "ultimately liberated one" (saish ü gedatsusha, Reader 2000a, 10), as a "guru" and an "honourable teacher" (sonshi). The second rank included only five members with the title of "sacred grand teacher" (seitaishi): Ishii Hisako, Tomoko (Asahara's wife), Ācharī (Asahara's third daughter), Murai Hideo and Jōyū Fumihiro.

Aum Shinrikyō's teachings combined Buddhist doctrines, yoga practices and catastrophic millenarian visions with the idea that the world was divided into the forces of good and evil and with the importance of strict ascetic practices to purify the body and eradicate bad karma.

Aum's doctrines and practices changed over time, reflecting the shifts in Asahara's teachings and problems faced by the movement when it developed from a yoga school to a movement with a more explicit religious character. Aum Shinrikyō's doctrine ${ }^{13}$ is based on early Buddhism, Mahāyāna Buddhism, Tibetan Buddhism and yoga practices. Initially, the concept of the awakening of kundalini, the original life energy released from the lowest of the seven or nine cakras (chakura), as a result of intense austerities, yoga and meditation, was central in Aum practice, which focused on yoga lessons and healing experiences through yoga (Asahara 1986). Later, the Hindu deity Śiva (Japanese: Shiva) became Aum Shinrikyō's main object of worship, from whom Asahara claimed to be receiving messages and advice and of whom he eventually claimed to be a manifestation (Reader 2000a, 66-67). With the increase in numbers of its members, a more defined cosmology was introduced, corresponding to different levels of practices and types of yoga. The universe was described as a multi-dimensional structure including four realms, the Realm of Desire (aiyokukai), the Realm of Form (keijōkai), the Realm of Non-Form (bikeijōkai) and the Mahānirvāna (mahā nirubāna) (Asahara 1991). The Realm of Form is also called asutoraru sekai (the Astral World) and it is divided into lower and upper levels, while the Realm of Non-Form is also called the Causal World (kozzaru sekai) and divided into lower, middle and upper levels (the Mahānirvāna is located in the upper causal world). The salvific faith system developed in Aum centred on the rite of Initiation (the text Initiation was published in Japanese in 1987 and translated into English in 1988 with the title Supreme Initiation). Initiation eventually included several different rituals, but the most practiced of them remained the shaktipat (shakutipatto), a Hindu initiation practice, which was performed by both Asahara and, from 1988, 
by high-ranking members (Reader 2000a, 72). The aim of the shaktipat was to accelerate the awakening of the kundalin $\bar{\imath}$ through the transfer of power and energy from the guru (or the person who has obtained gedatsu, liberation) by placing his or her thumb on the forehead of the person to be initiated (Reader 2000a, 72; Shimazono 1995, 394). ${ }^{14}$ Finally, in 1989, the teaching of Tantra Vajirayāna (Tantora Vajirayāna) was introduced as well as the concept of poa. In Tibetan Buddhism, poa refers to ritual services performed for the recently dead, including rituals of intercessions of merit transfer between the living and the dead (Reader 2000a, 18). As explained by Reader, in Aum teaching, the term assumed a more sinister nuance, as killing for salvation:

Not only was is used in the context of intercession after death: it also acquired a more active dimension, signifying intercession in life to save people from acquiring further negative karma that would hinder them at death. In other words, poa came to mean not simply an act of merit transfer after death, but a practice of intercession beforehand in order to 'save' the unworthy by 'transforming' their spirits so they could enter a higher spiritual realm. More bluntly, it was used in Aum as a metaphor for killing or having someone killed.

(Reader 2000a, 18)

Aum became increasingly focused on the belief that the world was heading for disaster by the end of the twentieth century and that an apocalyptic final confrontation between good and evil-in which Asahara and his devotees would fight to defeat the forces of evil-was inevitable. To prepare for this coming event, they began to manufacture weapons and to engage in acts of violence against people they perceived as "enemies", such as journalists criticising the group or lawyers supporting family members that accused the group of taking away their children or relatives. ${ }^{15}$ This escalating series of acts of violence culminated in the events of March 20, 1995, when members of Aum Shinrikyō entered five lines of the Tōkyō subway at the time of the morning rush hour, each carrying a plastic bag containing the poisonous gas sarin and umbrellas with which to puncture the bags. The attack left thirteen people dead and several hundred injured. Two days later, the police raided Aum Shinrikyō facilities nationwide, arresting over 400 and questioning even more members, confiscating documents and equipment. In October 1995, Aum Shinrikyō lost its status as a religious corporation and was placed under strict surveillance. Trials against individual members began. In early 1996, Aum Shinrikyō was declared bankrupt while facing large sums of compensation to its victims. Most members left Aum Shinrikyō, and the group's facilities were destroyed. Finally, on September 30, 1999, the movement dropped the name Aum Shinrikyō. On February 27, 2004, Asahara was sentenced to death, a sentence that was confirmed by the Japanese Supreme Court in 2006. 


\section{New Religions and Offline/Online Interactions}

While many of the most senior figures in Aum had been involved in its turn to violence, there were many devotees who were innocent of the crimes. While the majority of Aum members left the movement shortly after the sarin attack, a number remained faithful and sought to maintain the spiritual practices they had learned in Aum. For them, the issue of how to pursue their faith while demonstrating that they were not a threat to public safety has been a recurrent issue ever since.

\section{AUM AFTER 1995: ALEPH AND HIKARI NO WA ${ }^{16}$}

On January 18, 2000, Jōyū Fumihiro (b. 1962) and Muraoka Tatsuko (born 1950) announced that the organisation replacing Aum Shinrikyō was to be called Aleph, ${ }^{17}$ and was to be represented by Jōyū and Muraoka, not Asahara. They also announced changes in doctrine, stating that they would retain the practices of yoga and meditation but would discontinue teachings considered dangerous and wanted "to start from ground zero" with the organisation's structure. ${ }^{18}$ In 1999, according to the report submitted by Aleph in March 2000 to the Ministry of Justice, there were 23 leading members, 570 shukkesha and 365 lay members. Asahara was not registered as a member and Aleph at that time owned 26 buildings. Currently, Aleph has ten $d \bar{o} j \bar{o}$ (training centres) throughout Japan. ${ }^{19}$

In 2004, a minority group led by Jōyū Fumihiro started developing inside Aleph. The group was called "daibyōha" (literally, group of the representative, daiby $\bar{o}$, representative/delegate, is the name used by members to refer to Jōyū). For a while, the two factions shared the same facilities but organised different seminars and other activities. In March 2007, Jōyū and around 200 members left Aleph and set up a new religious organisation called Hikari no Wa (literally, Circle of Light; officially, The Circle of Rainbow Light).

Jōyū Fumihiro was born on December 17, 1962 in the city of Kurume in Fukuoka Prefecture on the southern island of Kyushu. Jōyu attended the private Waseda High School and then the prestigious Waseda University in Tokyo, where he graduated from its Faculty of Science and Technology. In 1987, he received a master's degree from the Waseda University Graduate School of Science and Engineering. In April 1987, he started working for the National Space Development Agency as a scientist. Jōyū first joined the group Aum Shinsen no Kai (later Aum Shinrikyō) during the summer of 1986 at the age of 23 (Reader 2000a). According to his autobiographical account (Jōyū 2012), he was attracted to the group because of his interest in paranormal phenomena, supernatural powers and yoga practice. He was an avid reader of magazines on "supernatural phenomena", which gained some popularity in Japan from the 1970s onwards, and he became interested in yoga and Zen Buddhism during high school. In May 1987, he decided to become a shukkesha (renunciant) and to live a communal life with other 
Aum members, and as a result, he quit his job at the National Space Development Agency. In July 1987, he engaged in very strict ascetic training practices for three months during which, according to his own account, he underwent several mystical experiences (Joyū 2012, 38-39). After the training, he received the sacred name of Maitreya ${ }^{20}$ and became one of Asahara's most prominent disciples. In the fall of 1987 , Jōyū was sent to the United States to open a new branch of Aum in New York, and then, in the fall of 1993, Asahara sent Jōyū to Russia as Aum's representative there. Jōyū did not return to Japan until after the sarin gas attack in March 1995, when he became Aum's spokesperson. In October 1995, Jōyū was arrested on charge of perjury and forgery in relation to a controversial land deal in 1990 at Namino in Kyushu, where Aum had acquired land to set up a commune. He was released from prison in December 1999 and, as mentioned above, returned to Aum to lead the group during the transition to Aleph and, eventually, to found the splinter group Hikari no Wa in 2007.

Approximately one quarter of Aleph members joined Hikari no Wa, but some of them left after a few months. At the end of 2010, the group numbered between 35 and 40 members permanently living in the group's facilities and approximately 200 "lay members". Further, the group claimed that around 200 members were based in Russia and that during the last few months of 2010, around 200 people approached the group and attended events and pilgrimages, without necessarily (or yet) joining it. ${ }^{21}$ The majority of members are ex-followers of Aum and their number has been steadily decreasing. As of December 2014, the group is claiming that only nine people are in charge of the centres, and that full-time members number only 17 (in 2012, the number of members leaving in the group facilities was 27, Jōyu 2012, 250). ${ }^{22}$ The use of the word shukke (renunciant) to indicate members living communal lives (a term previously also used by Aum) has been discontinued in favour of the more neutral term "full-time staff" (senju sutaffu). The estimated number of members, too, has decreased from 180 (Jōyū 2012, 250) to 114 members. ${ }^{23}$ There is a formal membership system, but most activities and meetings are open to non-members. The group has also established a Public Relations Department that deals with issues related to requests from media, relationships with local communities and contact with scholars.

Initially, Hikari no Wa declared that the focus of the new group would not be on the worship of a specific individual or god, but rather on the development of the "sacred" in every individual. ${ }^{24}$ In the same document, the group explains that it will incorporate different sacred symbols and practices from different religious traditions. At the moment, the group, while still encouraging previous practices such as yoga and meditation, has publicly renounced the strict and sometimes physically dangerous ascetic practices stressed by Aum, and it has started to introduce practices related to Japanese religious traditions, such as pilgrimages to sacred places and 


\section{New Religions and Offline/Online Interactions}

Shinto-based rituals. Hikari no Wa's website and printed materials present the group not as a religion, but as "a place for learning a new spiritual wisdom" (aratana seishintekina chie no manabi no ba), a "religious learning center" (shūkyō no gakushū sentā) and a "spirituality academy" (supirichuaruna akademī"). ${ }^{25}$

According to a textbook distributed to participants at Hikari no Wa's summer seminar in August 2010 (Hikari no Wa 2010), religion in the twentieth century has been characterised by several problems, including blind beliefs, fanaticism and conflict with society and among religious groups. Hikari no Wa proposes a "reformation of religion for the twenty-first century" (21seki no tame no shükyo no kakushin) that will be accomplished through a threefold path: rejection of blind beliefs (mōshin wo koeru) (Hikari no Wa 2010,37), overcoming dualism and the struggle between good and evil (zenaku nigenron to tōsō wo koeru) (Hikari no Wa 2010,39) and finally, overcoming the barrier between the religious community and society (kyōdan to shakai no kabe wo koeru) (Hikari no Wa 2010, 41; Baffelli 2012,37). More recently, the group has started presenting itself as a "religious philosophy" (shūkyō tetsugaku). Hikari no Wa claims that its doctrine introduces a new idea of faith and of the divine and that it is not necessary to believe in any particular faith or god in order to be saved. Members, it is claimed, do not believe in a transcendental being or in an absolute leader. Instead, the focus is on cultivating the "sacred consciousness" (shinseina ishiki) in each individual and in particular, the love for all people and all things, compassion and benevolence. God itself is seen as a symbol of the individual "sacred consciousness." Special people, such as Buddha, Jesus and Muhammad, are external symbols of the divine. Symbols may differ, but the sacred consciousness is unique and remains constant. The idea of a "guru" or absolute leader, therefore, is rejected, and peace and equality among religions are advocated.

Hikari no Wa has also been introducing new practices in an attempt to distance itself from Aum Shinrikyō, while retaining aspects of Aum's teaching and practices that still appeal to members. Hikari no Wa's activities and practices can be divided into three groups. First of all, there are training activities performed at the $d \bar{o} j \bar{o}$. Different training methods are used, such as yoga, qigong, healing techniques, Buddhist meditation and esoteric Buddhist practices. A variety of objects and techniques are used during meditation, such as music and sounds, incense, Buddhist images, Buddhist statues, ritual paraphernalia, "holy" water from sacred places (gojinzui, seizui) and astrology. Members are free to choose any of these practices, but they are discouraged from engaging in extreme asceticism. Counselling sessions with Jōyu and other representatives are also offered at the centres. Furthermore, Jōyü's preaching lectures are held approximately every month, and intensive seminars are held three times a year (in May, August and at the end of the year). In 2012, a well-known Japanese therapeutic practice of 
self-reflection called naikan (introspection) was introduced. ${ }^{26}$ New practices are introduced regularly, while previous practices are discontinued or modified. In the process of distancing itself from Aum, several practices needed to be reconsidered or abandoned, but at the same time, Hikari no Wa was attempting to find a new and original identity.

Hikari no Wa emerged from the ashes of Aum Shinrikyō and has tried to reshape and reformulate its teachings in order to make them more acceptable, while at the same time drawing on some themes and image strategies already used in Aum. Therefore, some comments about Aum's use of media are required to understand Hikari no Wa's engagement with new technologies.

\section{AUM SHINRIKYŌ ON THE INTERNET}

From the outset, Aum Shinrikyō showed a sophisticated use of media for both internal and external use. The group produced a large quantity of printed material (books, pamphlets, magazines, leaflets, manga and so on), as well as promotional videos, music recordings, radio broadcasting (in 1990, Aum established a weekly radio broadcast from Russia), tapes of Asahara's lectures, and anime. The contents of materials produced by Aum were conceived differently depending on their audience (members, core members or the general public; see Inoue and RIRC eds. 2011, XVII) ${ }^{27}$ Aum, therefore, used its own forms of media to attract new members, support current members' practices, impart esoteric teachings to core members and counteract external media representations of the group.

Asahara's supposed supernatural powers gained the attention of some magazines devoted to occult-related topics, such as The Twilight Zone, and several members have declared that their first encounter with the group was through these publications (Joyū 2012; Reader 2000a, 100-101; Watanabe 2005). The publishing market played an important role for the group, which set up its own publishing company (Oumu Shuppan) and marketed and distributed Asahara's publications in bookshops (Reader 2000a, 101). The first three books by the leader, Chōnōryoku: Himitsu no kaihatsubō ("The Secret of Developing Supernatural Power"), Seishi o koeru ("Beyond Life and Death") and Inishēshon ("Initiation") were published in 1986, and in the same year, Aum's first monthly magazine, Mahāyanna, was established. Aum also set up an in-house production team called the Manga Anime Team, formed by amateur artists, that produced several manga and anime to be used for propagation activities (Okada 1997) and to advertise other publications as well as goods and shops managed by the group (Schodt, 1996, 231). The manga and anime were based on Asahara's teachings, and the leader played a central role in their narratives. They also featured stories about the experiences of young people joining the group 


\section{New Religions and Offline/Online Interactions}

(as, for example, the three volume series Spirit Jump mentioned in Chapter 2 in this volume)..$^{28}$

The relationship between Aum and popular culture received media and scholarly attention after the 1995 sarin gas attack. For some critics, the apocalyptic and end-of-the-world themes that appeared in several manga and anime produced in the 1970s and 1980s influenced Aum's beliefs, and it was suggested that members became unable to distinguish between reality and fictional worlds (Gardner 2008). Aum had indeed consciously borrowed some of the atmosphere of expectation about an apocalyptic scenario that might occur at the end of the century that had been created in pop-culture works of the time. In his memoir, Jōyū Fumihiro (2012, 37) recalls his fascination for supernatural powers and for the apocalyptic imaginary. In his opinion, some publications (such as Uchū senkan Yamato, "Space Battleship Yamato") made the members familiar with particular topics, and possibly more prone to accepting Asahara's ideas of the world (and the group itself) as threatened by evil forces and to expect upcoming disasters. However, the discussions about possible influences from manga and anime on Aum's teachings and actions did not provide convincing arguments to support such claims (Gardner 2008, 215-216). Indeed, as other studies have demonstrated (Reader 2000a; Shimazono 1995) Aum's teachings and visions were strongly influenced by existing apocalyptic concepts found in Christian and Buddhist texts. An interesting aspect, however, is the ability demonstrated by Aum to follow existing trends and ideas and to test new communication strategies.

Aum's dynamic approach to media is also evident in its use of computer-based communications. In 1991, Aum launched its own private network, Aum Shinrikyō Net, and set up a discussion room on Fujitsu Nifty Serve, which at the time was one of the largest networks in the country (Fukamizu 1994; 1996; Watanabe 2005, 47). According to a survey conducted by Fukamizu $(1994,66)$, in 1994, Aum Shinrikyō Net had 300 registered users and half of them were members of the organisation. Around 30 users declared that they had joined the group through the Net. However, it was also possible to access Aum Shinrikyō Net as a guest (Fukamizu 1994, 66-67), and thus the number of actual users was possibly higher. According to opinions expressed by the organisation and reported by Fukamizu (1994; 1996), there were three main aims for its establishment of computer-based communications: proselytism based on written texts, a possible way to join the group and a form of proselytism different from face-to-face interaction. Aum Shinrikyō Net provided access to material produced by the group, including videos and explanations about teachings, but, more interestingly, included a chat site where users could ask questions about Aum Shinrikyō directly to the group's representatives and an area called Free Talk (furi $t \bar{o} k u$ ), where users could freely express their opinions and ideas (including negative comments and criticism against the group, as is indicated by the 
examples provided in Fukamizu 1994, 72-73). Although the effectiveness of computer-based proselytism in attracting new members at the time was probably very modest, Aum Shinrikyō Net demonstrated Aum's early interest in new media for proselytism activities. Online interactions also lead to the creation of offline meetings, face-to-face meetings for members who had met on the Net (Fukamizu 1994, 82), which, although not particularly successful at the time, share similarities with the ofu kai (offline meetings, from ofurain mitingu) meetings established years later by Hikari no Wa that will be discussed below.

"Aum-Internet" was also the name of the first website set up by Aum Shinrikyō a few years later in 1997 (Fig. 5.1), after the sarin attack and as Aum's remaining devotees were trying to come to terms with what had happened. The website included detailed information about Aum's teachings and practices, and users could download Aum music (Fig. 5.2) and Asahara's speeches as well as some of his publications, such as, for example, the text Seishi o koeru ("Beyond Life and Death"). Compared to other new religions' websites in the same period, Aum-internet.org offered a higher degree of interactivity and showed a deeper attention to graphic and content presentation. It also included an elaborate online shop selling books, anime, videos and so on produced by the group and a series of
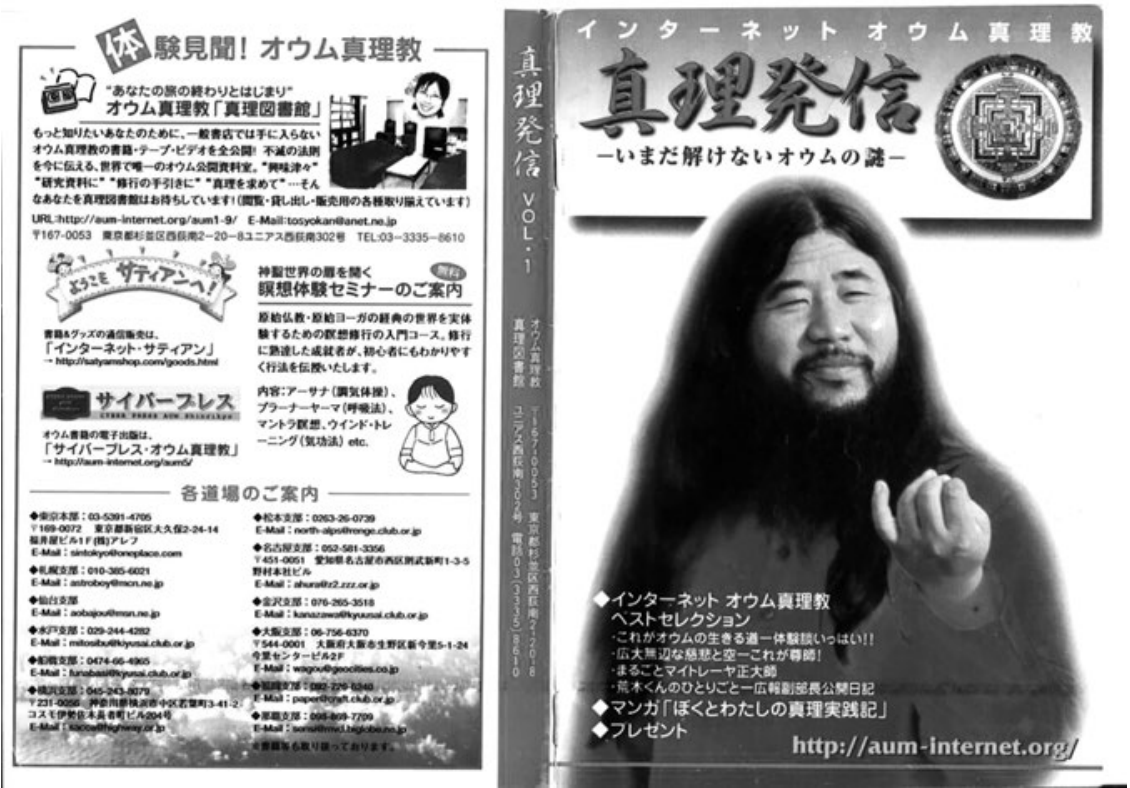

Fig. 5.1 Advertisement for Aum Shinrikyō's website. 


\section{MUSIC PROGRAM}

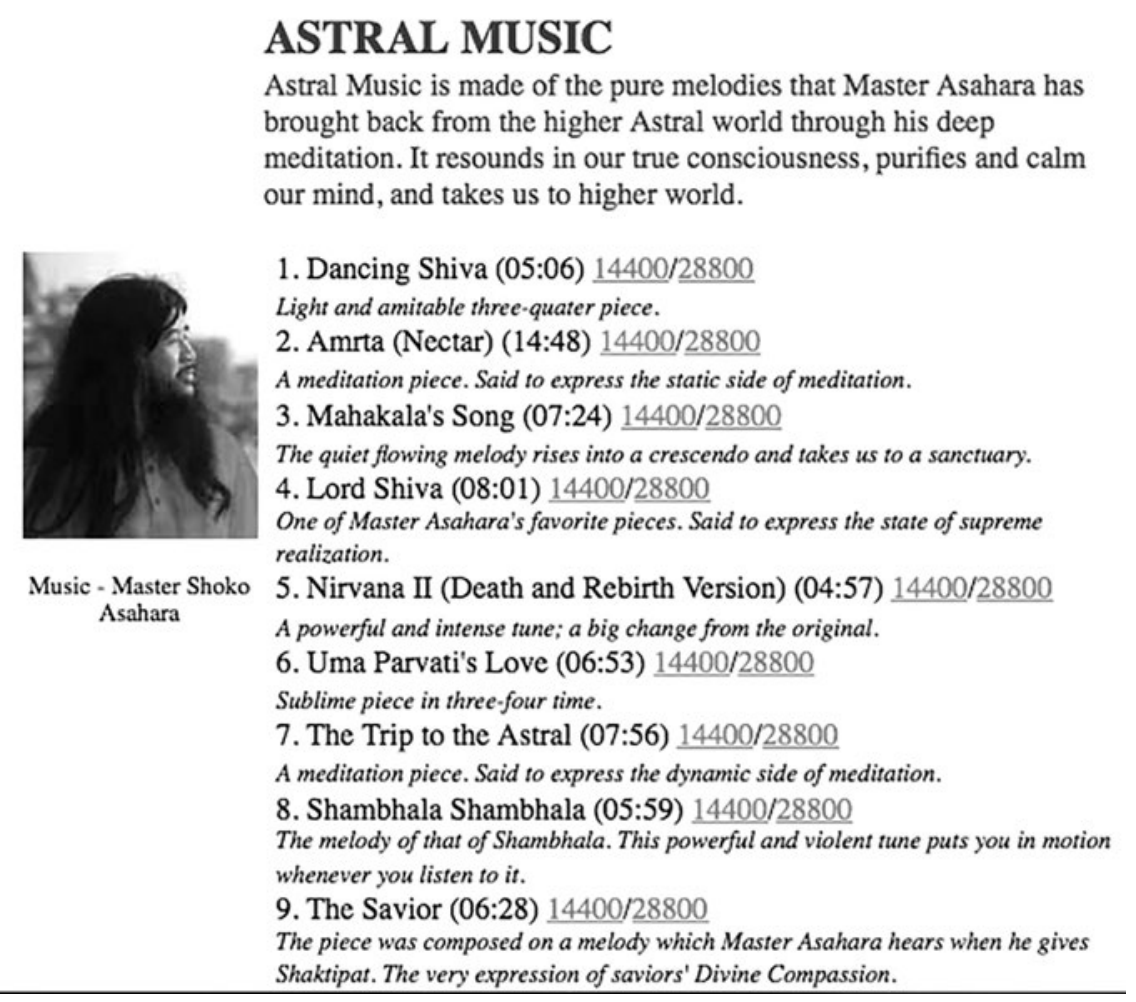

Fig. 5.2 Astral music available for download on Aum Shinrikyō’s website.

Aum-related goods (elephant deity Ganesha-shaped hats, mugs, posters of the leader, clothes, series of photos of high-ranking members and so on; see Fig. 5.3).

Aum-internet.org was heavily modified in July 2000 and replaced with a new website, Aleph.to, while the old version was available for few months on a mirror site, (aum-shinrikyo.org, maintained by Russian members but now discontinued; Baffelli 2000, 61). The new website reflected not only the renaming of the group, but also the new directions that the group intended to take. Although at the beginning, Aleph.to maintained graphics (for example, the use of pink and blue, with animations) and structures (i.e. members- and advanced members-only sections) that were very similar to the old website, the figure of Asahara was much less visible (Fig. 5.4).

From the beginning, Aleph has been very active online and has used the Internet to keep in contact with members and as a promotional tool. Indeed, 

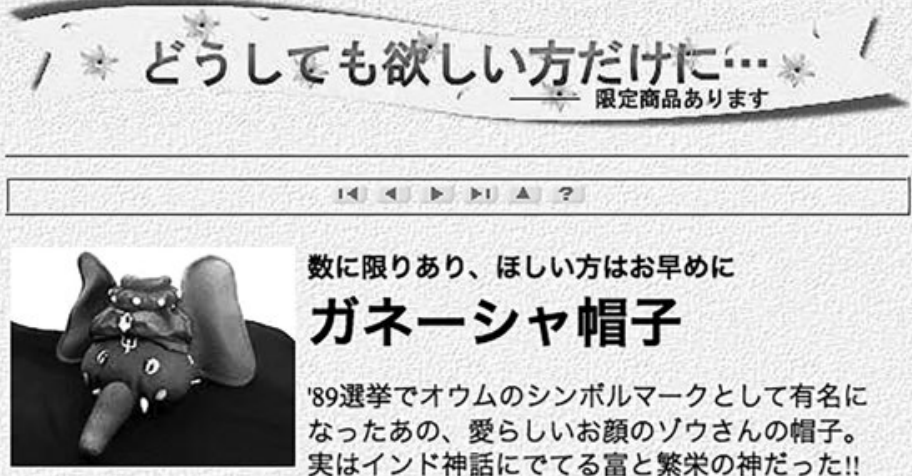

数に限りあり、ほしい方はお早めに

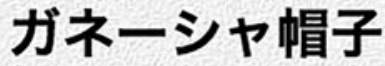

'89選挙でオウムのシンボルマークとして有名に なったあの、愛らしいお顔のソウさんの帽子。 実はインド神話にでてる富と繁栄の神だった!! 選挙で頑張った名残を残した貴重品。招福。

※申し訳ありませんが

お値段は直接お問い合わせください。

\section{$144 \backslash 14 ?$}
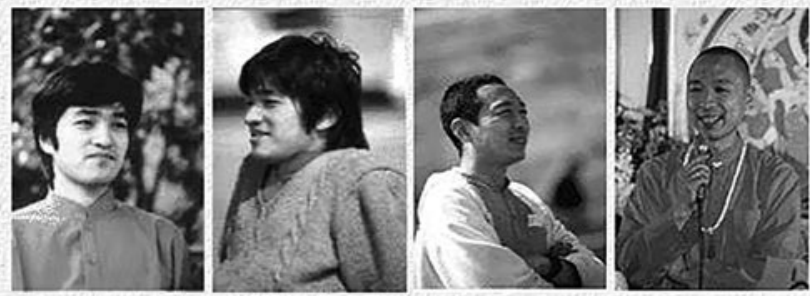

本当にほしい方だけに
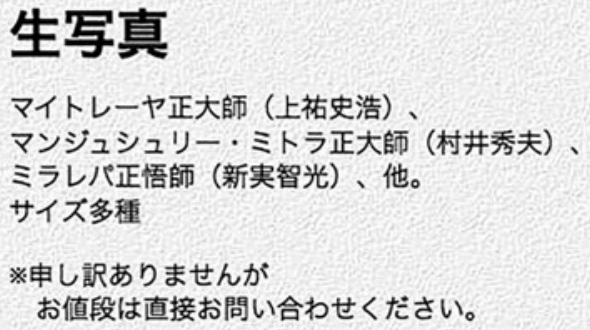

Fig. 5.3 Goods for sale on Aum Shinrikyō's website.

the use of the website as a chief tool for communication allowed the group to communicate easily with other members living either in scattered communes or unrecognised as lay members, and to present itself online as a community of Buddhist believers and yoga practitioners, to apologise for Aum's earlier activities and to report compensation given to Aum victims while ensuring the anonymity of (lay) members. 


\section{New Religions and Offline/Online Interactions}

Aleph

カร閶い合わせ|このサイトについて|サイトマップ

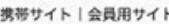

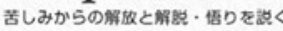

Q模表

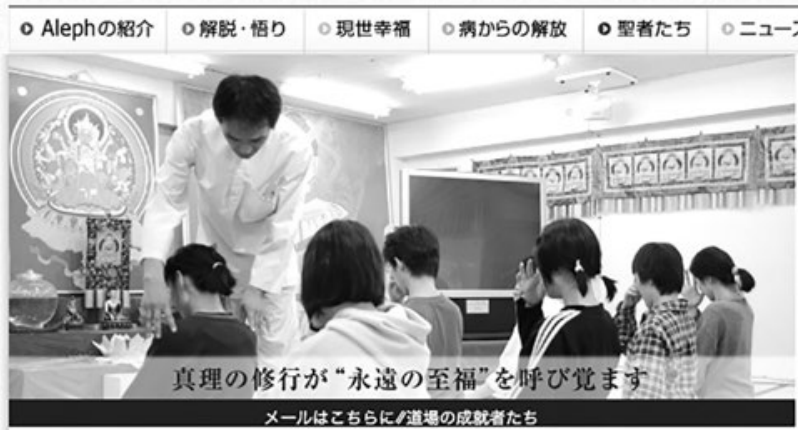

新着情報

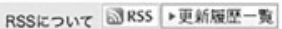

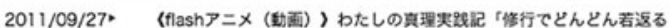

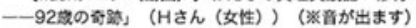

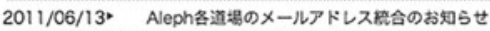

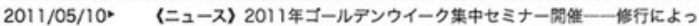

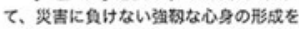

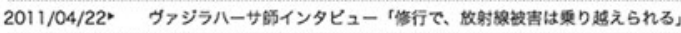

$2011 / 04 / 16$ * 東日本大震災の没復金受付思口について

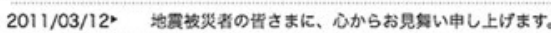

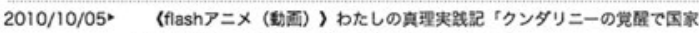

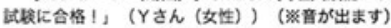
Aleph «งเฉ Q\&A
eph Internet Broadcasting

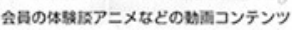

会用サイトロソイン

○入会のこ萦队

○ 全国の沮堨のこ案内

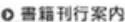

タ)

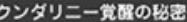

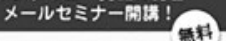

アドレスを胡入してください

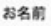

$(=\geqslant$ (4)

$x-\pi$.

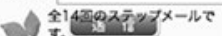
\#し<は255

Alephの紹介 twoduction of greph

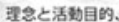

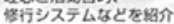

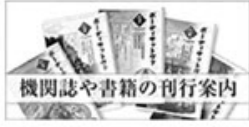

Fig. 5.4 Aleph's official website.

\section{HIKARI NO WA AND THE INTERNET}

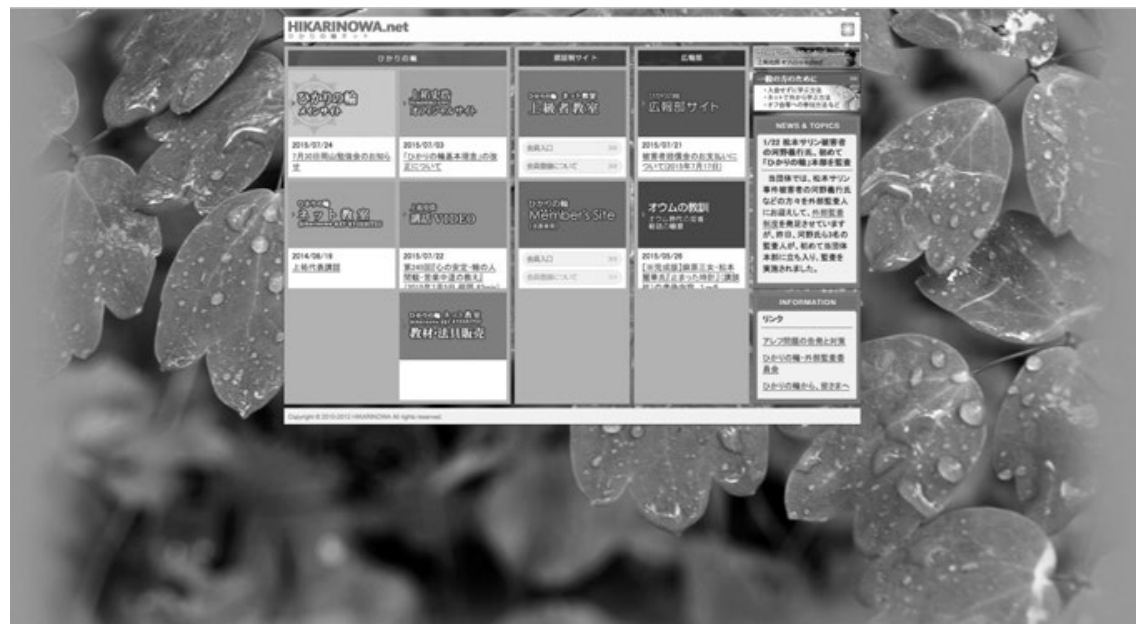

Fig. 5.5 Hikari no Wa's official website. 
Hikari no Wa opened its official website (Fig. 5.5) in conjunction with the announcement of the foundation of the new group at the beginning of May 2007. The website included detailed information about the group's activities, practices and doctrine, and also a section called Oumu no kyōkun (Lessons From Aum), which contained members' self-reflections about Aum Shinrikyō's activities, including the 1995 attack and their decision not to leave the group after it was found guilty of several crimes. ${ }^{29}$ The website also included the development of a "Net Dōjō" ${ }^{30}$ (Netto dōjō, recently renamed "Net Classroom", Netto kyōshitsu, Fig. 5.6) to promote specifically online religious activities, related to the idea expressed at the time by Jōyu Fumihiro that "the 21st century will be the place for Internet religion" (netto sh $\bar{u} k y \bar{o}) .{ }^{31}$ According to the group, this would allow members who were not comfortable attending practices and activities because they feared negative repercussions if they were seen entering the group's premises to still participate in the group's activities. ${ }^{32}$ Recently, a Net Shop has also been opened that sells CDs and DVDs produced by the group and items for Buddhist rituals. ${ }^{33}$ The website has been modified several times over the last few years, following changes in the image the group wants to transmit about itself; as mentioned before, between 2013 and 2014, for example, the group has been reformed and its now presenting itself as a "philosophy classroom" (tetsugaku kyōshitsu) and no longer as a religious organisation.

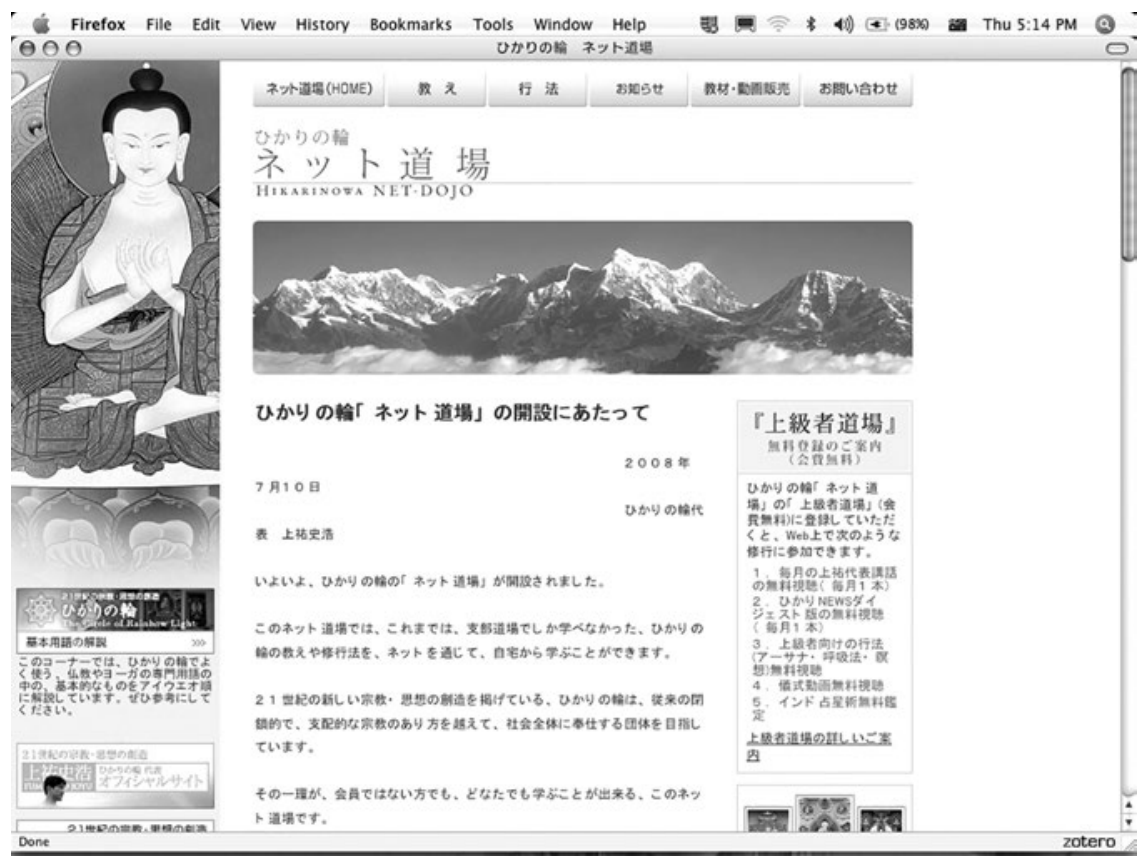

Fig. 5.6 Hikari no Wa's Net Dōjō. 


\section{0}

\section{New Religions and Offline/Online Interactions}

In the early stages of its formation, however, online communication was mainly focused on conveying Hikari no Wa's message about its new identity and rejection of Aum's practices. In an interview in January 2009, Hikari no Wa's representatives clearly explained to me that they considered the website both as a way to promote the group and to publicly express their point of view concerning Aum Shinrikyō's activities. Indeed, at that stage of their formation, because of economic factors and the difficult position their connection with Aum had put them in, the group had no access to other media. Hence, it had to use the Internet to both spread its message and attract external media interest. In contrast to the press or to far more expensive media such as satellite television, the Internet is easily accessible for most people in Japan, and online content is relatively inexpensive to produce. The fact that the website was created with the cooperation and input of the group's members indicated the group's awareness of the potential of the Internet to change the group's perceived image and to improve the possibility of it being recognised as a group that was different from its predecessor.

Indeed, the image of the group presented online was initially centred on its desire to separate itself from Aum. Often, this image was constructed consciously as the opposite to that of Aum; openness was stressed over exclusivity, and explanation privileged over secrecy, as can be seen in the inclusion of members' detailed explanations of Aum Shinrikyō's activities, which stands in stark contrast to Asahara's refusal to speak about such things during his trial. ${ }^{34}$ Finally, the image of the leader played a central role in the negotiation of the group's new identity, and these dynamics are reflected in its use of the Internet. Through its online presentation of Joyū, Hikari no Wa has emphasised that Joyū is accessible and human rather than distant and mysterious. The group has strongly and publicly rejected Asahara's authority and during an interviews I conducted in 2009 , stated that Jōyu is not a leader or master, only a more experienced member of the group. ${ }^{35}$

The desire to present Joyyu as approachable and open to dialogue has translated into specific ways of presenting his image online. Hikari no Wa's website was initially registered under Jōyū's name (joyus.jp) and, amongst other features, included Jōyū's diary. In 2008, the diary was moved to Jōyū's page on Mixi, ${ }^{36}$ that at the time was the biggest social network in Japan. ${ }^{37}$

Jōyū's Mixi diary took the form of a personal blog, combining musings, memories, reflections on his religious practice and training, photographs and essays on religious topics. Furthering the group's desire to appear open and democratic, on his website and weblog, Jōyū expressly asked his readers for their opinions and invited them to send him their comments by email or by joining his friends' groups on Mixi. Even this process was highly personal and interactive; to join the group, people were required to send a message explaining why they wished to join. On Mixi, Joyū immediately attracted a significant number of requests to be added to other users' MyMIXI lists (similar to friend lists on Facebook or MySpace), and in June 2009, it reached the 1000 -friends limit allowed by the service. According to the greeting messages 


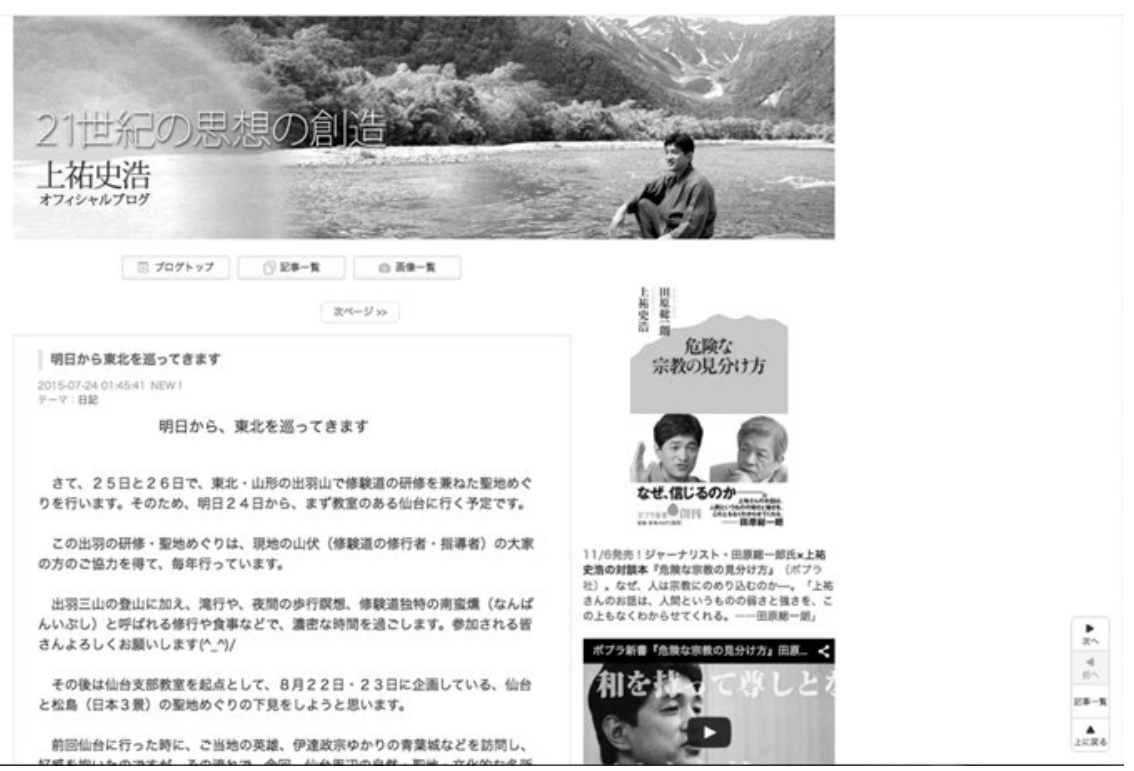

Fig. 5.7 Jōyū Fumihiro’s blog.

listed on Joyū's page, many users declared that they wanted to connect with him because of his celebrity status, stating that he is famous (yümeijin) and/ or attractive (kakkōii). To foster this exchange with users, in October 2010, Jōyū started a blog (Fig. 5.7), ${ }^{38}$ in which he also replied to comments and questions that had been asked by readers on Twitter.

The group also established a YouTube channel (Hikari no Wa Dōga, renamed in 2014 as Hikari no Wa Movie), ${ }^{39}$ which includes videos along with the Joyū's public talks and the group's official press conferences. However, the possibility for viewers to make comments underneath videoswhich is a leading interactive feature of YouTube - has been disabled. From September 2009, the group also started online live broadcasting through Ustream, streaming Jōyū's Buddhist sermons $(s e p p \bar{o})$ from Hikari no Wa centres around the country. Initially, the talks were streamed once or twice a month. Jōyū's streaming videos are now freely accessible to everybody, but until November 2010, access was limited by a password that could be obtained by sending few personal details (name or nickname, gender and age) to the representative in charge of the Net Dōjō. In December 2010, the group opened a new section of the website entirely devoted to video streaming and the collection of older videos from YouTube and Ustream. ${ }^{40}$ Unfortunately, because the names of viewers are not visible, there is no way to evaluate and observe who the people are who are watching the streamed videos. The average number of online viewers was initially quite low, between 20 and 25, but it grew during the last months of 2010 and almost doubled 


\section{New Religions and Offline/Online Interactions}

by the beginning of 2011. They might be members living far away from the centres, or, as pointed out by the group's representative during interviews, members who prefer not to be seen entering the group's facilities. Or perhaps, they could all be scholars or police officers who are monitoring the group's activities and new developments. ${ }^{41}$ Furthermore, just because they are watching it, this does not mean that they are engaging with Joyū's talks and his teachings. Especially in early videos, Jōyū's lectures were sometimes focused on criticising Aleph and stressing the fact that Hikari no Wa had rejected Asahara's leadership or on presenting rather didactic introductions to Buddhism teachings, rhetorically emphasising a clear separation between "good" and "evil". This could possibly indicate his awareness that the viewers might not necessarily have been potential members, but also people who were interested in monitoring his activities and evaluating his relationship with Aum's doctrines and activities. Thus, these streamed videos also served as opportunities for the group to publicly declare their dissociation from Aum and to reply to possible criticisms.

The reliance of Hikari no Wa on streaming videos and social media such as Mixi and, more recently, Twitter and Facebook, raises questions as to why the group had prohibited comments on YouTube and on the leader's blog. I suggest that the answer lies in the characteristics of the specific social networking sites and interaction features used by the group. Indeed, despite the apparent openness of Jōyū's image online, interactions with the leader are controlled by the group. The inbuilt interactivity of video sharing websites such as YouTube, where interaction is encouraged and debates are created by users through the comments feature, is very difficult to control for the group, which might find an open debate space too challenging and time consuming. On the contrary, Ustream is a safer information zone where unwanted challenges may be controlled through the use of passwords and registration. Similarly, interactions between Jōyū and members/users in Mixi were controlled through specific features. For example, anonymous comments were not allowed, and one was required to explain the reasons why one wanted to join Jōyū's blog or the group's forum. Besides, a function called ashiato (footprints) allowed users to check who was looking at their profiles. The preoccupation with an uncontrolled stream of comments and criticisms were confirmed to me by Jōyu during an interview in November 2010 when replying to my question about why comments were not allowed on his blog. Furthermore, the group's concerns proved to be true when comments were allowed for the first time live during some streamed talks at the end of December 2010. Some of the questions typed on the screen, indeed, were completely unrelated to Joyyu's talk, and the integration of online viewers into the live event at the centre proved to be more difficult than expected.

Joyyū's diary on Mixi offered users an opportunity to get in contact with a celebrity of sorts and it therefore attracts users seeking "a sense of connection with the "extraordinary" (Chin and Hills 2008, 258). Just as fans seek to achieve intimacy with celebrities by commenting on their blogs (Chin and 
Hills 2008), Mixi users added Jōyū in their maimiku (my Mixi), or friends' list. Joyū's confessions on the blog created an image of accessible celebrity and increased his credibility, much in the same manner that Redmond has noted of larger celebrity culture:

Stars and celebrities confess-they always have invested in the revelatory mode of self-enunciation-but in the self-reflexive, ubiquitous, highly stimulated environment of $24 / 7$ media culture today, they centrally rely on the confessional to authenticate, validate, humanize, resurrect, extend and enrich their star and celebrity identities. Stars and celebrities confess, and in so doing confirm their status as truthful, emotive, experiential beings who-as devotional fans-we can invest in.

$(2008,109)$

But at the same time, these expressions of non-self-disclosure and self-disclosure (Chin and Hills 2008) are filtered and controlled: the privileged knowledge about Joyuu's life was based on a selection of accounts and descriptions aimed at constructing an image of an "anti-Asahara". Jōyū carefully maintains his image as a (relatively) young, handsome and approachable teacher, but also as someone who is very serious about his training and discipline.

One of the primary aims of social media is to connect people and facilitate communication between users. According to Takahashi (2008), because of its specific characteristics, Mixi is a public space that is "nonetheless perceived as private" (Takahashi 2008, 24) and people tend to "trust it" and create "intimate" communities to reinforce real social relationships. Therefore, it offered Hikari no Wa a very useful tool to publicly announce to the general public its reformed identity. Online popularity is established through social media and "depends upon a connection to one's audience rather than an enforced separation from them" (Senft 2008, 26). From this point of view, Jōyū's use of social media represents an adaptation of the traditional leader-members interaction to the new media and an attempt to recreate an at least perceived proximity between leader and members. It is possible to speculate that social media also offered an opportunity to ex-Aum members (most of whom had lived in Aum's communes) to test the response of the public sphere to their return to the everyday world. In an interview, Hikari no Wa's webmaster mentioned that Jōyū himself liked Mixi because he didn't have many opportunities to become friends with "ordinary people" (ippan no kata) and to communicate with them.

Hikari no Wa gradually shifted from a one-to-many communication style, which still characterises its official website, to an increasing engagement with many-to-many communication, which, according to Castells (2001), represents the main characteristic of the Internet. Instead of integrating the users' participation into the official website, the "interaction zone"- defined by Helland (2005) as an area on websites that provides not just information, but a space where the information provided "can be lived" (Helland 2005, 13)—has 


\section{New Religions and Offline/Online Interactions}

been located on different sites' (initially Mixi and more recently, Twitter) privilege networked interactions. It follows that these interactive features also serve as opportunities for Jōyū to promote a new idea of a religious authority, a transparent image of a leader who is no longer untouchable, but who now interacts with members, or fans, online, "sharing his or her life in more unfiltered manner" (Burns 2009, 50). This accessibility provides an example of a very different approach compared to Kōfuku no Kagaku's leader, Ōkawa, and his decision to limit direct contact and public exposure from the second half of the 1990s to 2008, as discussed in Chapter Four.

A further development in this interaction was the establishment in 2010 of off kai (offline meetings). The off kai are usually held at public halls and create a neutral space where interested (or simply curious) people can meet and talk with Jōyū and Hikari no Wa members. During the meetings, participants have declared that they prefer to meet the group outside its facilities, because they still do not feel comfortable visiting the centres because of the "dangerous" image linked to the group or because, especially in Tokyo, they don't want to be stopped and questioned by the police officers who stand outside HIkari no Wa's headquarters.

On December 23, 2010, I participated in an off kai meeting in Tokyo. Around 20 external members participated. Female participants were slightly more numerous than males and the age range was around 35 plus. The meeting was held in a rented room at a public hall in central Tokyo and the room was booked under the name of the member in charge of Hikari no Wa's Tokyo centre as Xsan no kai $(\mathrm{X}=$ the family name of the Tokyo representative). Participants introduced themselves in small groups, disclosing the nicknames they used on Mixi and their real names. This was followed by a 30-minute demonstration of Qigong exercises lead by a Hikari no Wa staff member. After a short talk by Jōyū, he invited participants to ask him any questions. The questions asked ranged from the existence of UFOs, to the idea of direct ascension (asenshon) to Heaven, to how to achieve happiness. Joyū replied at length to each question, using them as prompts to talk about Hikari no Wa's teaching and to criticise apocalyptic thought and competitive society, and to attack Aum and Aleph. Finally, he provided some details about Hikari no Wa practices (yoga, Qigong, pilgrimage, meditation) and ritual objects, and presented recently released meditation CDs. Participants then were divided into small groups (of six or seven members each) with at least one full staff member for each group. I was assigned to a group with seven participants, including two non-members, two full staff members, a long-term member who used to be a member of Aum (but never lived in an Aum commune) and a young member who had joined Hikari no Wa in May 2010. The two external members asked numerous detailed questions, mainly about the structure of the organisation (membership, yearly activities, fees for participating in activities). They also showed curiosity about why members joined Aum in the first place, and why they left and joined Hikari no Wa. Both external participants approached the group via Mixi. They both 
declared that they had some interest in religion, but they were very critical about Aum and supernatural experiences. One of them had also read the testimonies of ex-members published on Hikari no Wa's website and he was particularly intrigued by in the life history of one of the members in charge of Hikari no Wa. It appeared clear that the main aim of attending the meeting was to satisfy their curiosity about Aum and Jōyu. The two full-time members in their replies stressed the idea that Hikari no Wa was now free from Asahara and they attempted to present their activities as transparent. The two external members were repeatedly invited to visit the centre and to attend seminars at the centre. In a room next door, participants could have a one-to-one conversation with Jōyū or have a trial of Hikari no Wa's healing and meditation techniques.

Off kai seemed to provide Hikari no Wa members with an opportunity to present themselves to a larger public and to demonstrate that this was a safe, and perhaps even "boring", ${ }^{42}$ group. For participants, the off kai was a way to satiate their curiosity about Aum Shinrikyō (an interest mainly based on media reporting about the group and on their memory of the sarin gas attack) in the safe and anonymous environment provided by the a public hall.

\section{Offline/Online Interactions and Religious Authority}

The first issue to be considered in discussing these offline/online interactions is that the online communications of Hikari no Wa cannot be fully understood without considering the specific historical background of Aum-related groups and representations of their leaders. The Internet is not some place "other", but needs to be understood in its relationship with other media and offline activities (Baffelli et al. 2011). Indeed, it is important to note here that Hikari no Wa represents an exception in the use of the Internet by religious groups in Japan, due to the specific situation of the group and its relationship to Aum. Many Japanese perceive Jōyū and Hikari no Wa still to be linked to Aum, and the fear associated with the group has made it very difficult for Hikari no Wa to maintain any form of public visibility. As a consequence, the web offers an important tool to the group to spread its teachings, claim its new path and engage in dialogue and discussion with members and other users.

Similarly, to understand Jōyū as an online "celebrity", one needs to be aware of the history of the group and the role played by Joyū as spokesperson of the group before and after 1995. In particular, immediately after the sarin gas attack in March and until the arrest of Asahara in May, as spokesperson of the group, Jōyū, together with other members, such as Murai Hideo and Aoyama Yoshinobu, frequently appeared on popular television talk shows, to the point that he and other members were said to have become more wellknown in Japan than most politicians (Gardner 2001,139). They were often compared to TV “idols" or TV personalities known as talento, and Joyū in particular was portrayed as exceptionally able in talking with reporters, 


\section{New Religions and Offline/Online Interactions}

and he "even succeeded on occasion in getting reporters to laugh along with him at his jokes" (Gardner 2001, 140). For his ability to reply to journalists' questions and criticism he was nicknamed "aa ieba, jōyu", a wordplay based on the similar sound of the last two words of the idiom a ieba ko iu, meaning "to have a comeback for every remark", and his last name ( $k \bar{o} i u-j \bar{o} y \bar{u})$. Similar to a popular actor or singer, Jōyū became popular especially among young women (called "Jōyū girls"), who founded a Jōyū fan club. ${ }^{43}$

The interaction between Jōyu and users online also raises some important issues related to religious authority. The question of authority on the Internet has been the subject of previous theoretical discussion. For example, Campbell (2007; 2010) distinguishes between "multiple layers of authority" $(2007,2)$ hierarchy, structure, ideology and texts-that might be affected differently by the Internet, and also points out the power of religious institutions and communities to shape the way the Internet is used. Baffelli, Reader and Staemmler (2011) have discussed through different case studies how religious authority is discussed and challenged on the "Japanese Internet" and in a religious context "in which hierarchy, structures, rituals and practices tend to be greater sources of offline authority than are doctrines, religious texts and their interpretations" (Baffelli et al. 2011, 30). As pointed out by other researchers, the Internet can potentially challenge the "plausibility structure"-the social (or sociocultural) base that a system, in this case, a system of meaning or beliefs, needs for its continuing existence- of a religious group (Barker 2005, 74; Berger and Luckmann 1966) and the role and perception of authority, especially charismatic authority. Charismatic authority, as discussed in Chapter Two, is defined as arising from the perceived extraordinary characteristics of a leader (in this case, a religious leader) and developing out of a relationship between a leader and followers. According to this definition, charismatic authority heavily depends on this relationship and on the recognition and legitimation of authority by members.

On the one hand, although the Internet can offer the potential to challenge the strong vertical authority structures of many new religions, the official webpages of most groups more often than not merely reflect the offline structure of the group and, in general, offer low levels of interactivity, focusing instead on the one-sided dissemination of information and on advertising a group's activities, publications and other products. That being said, a close reading and analysis of such websites is still a valuable part of the study of the use of the Internet by religious institutions and can help us to understand how religious groups present themselves, both to their members and the wider public.

On the other hand, social media are creating new spaces in which to relocate authority and assert alternative ways of interaction between a group's leader(s) and its membership, an interaction based on a virtual proximity and the sense of intimacy created by a leader's diary or other online forms of personal disclosure. Social media have allowed Jōyū to present his group to the larger public by blurring the boundaries between the public and the 
private and creating the feeling of a quasi-private conversation with the leader in a public space. At the same time, the nature of Mixi has allowed Hikari no Wa to control visitors and comments, limiting critical attacks, especially during the fragile early stage of its separation from Aleph. Differently from many other weblog platforms, on Mixi, anonymous comments from non-registered members are not allowed. This means that negative comments, which are common in other forums (see Tamura and Tamura 2011), were less frequent and Hikari no Wa could also control its share of Mixi's content by refusing or revoking users' registration. In this case, an efficient use of social media, demonstrated also by the ability to move to different platforms when Mixi decreased its popularity with Japanese users, can be seen as a means to strengthen authority, reinforcing the official images of a leader who is open to dialogue and criticism, while all the while maintaining careful control of his/her self-disclosures and interactions with members/users. A further observation regarding religious authority online arises when we consider the fact that in online interactions, the boundaries between religion and entertainment can potentially become increasingly blurred. Jōyu became a Mixi celebrity, but the idea of a "celebrity-leader" is not created online, but replicated by his offline image as a talento, which, as mentioned earlier, was created by television in the late 1990 s, confirming that online representations of religious leaders should be understood not as opposed to, but rather complementary to, their representations in other media.

Despite Zaleski's prediction that the Internet will favour religious organisations that "lack a complex hierarchy" $(1997,111)$, Hikari no Wa's example shows that online engagement by a (charismatic) leader might reinforce his/her claim of authority (and also a claim of rejection of a previous type of authority) and offer the possibility of reaching a wider audience. Hikari no Wa's case, however, has also demonstrated that strongly controlled online interactions may not necessarily attract new members (Hikari no Wa is now a very small group). However, they do provide support to a movement that otherwise has difficulty gaining access to other media ${ }^{44}$ to enhance its visibility and to attempt to extend its message to the public sphere.

\section{NOTES}

1. Studies on religion and the Internet developed in late 1990s. The first study investigated online practices and their effects on traditional religious practices and religious identities (Beckerlegge 2001; Cobb 1998; Davis 1998; Dawson 2000; Dawson and Hennerby 1999; Larsen 2001; O’Leary 1996; O'Leary and Brasher 1996; Zaleski 1997). Dawson and Hennerby conducted one of the earliest surveys on new religious movements on the Internet and included two Japanese groups (Dawson and Hennebry 1999: 22-3). The Journal of Computer-Mediated Communication devoted three Special Issues to religion on the Internet in 1998 and 2007 (one of the two Special Issues in 2007 included several articles on Japanese religions online). Further studies have developed 


\section{New Religions and Offline/Online Interactions}

conceptual frames to analyse religion online (Helland 2000) and for defining cyber-religion (Brasher 2001; Højsggard 2005). Other studies addressed specific topics, such as online religious communities (Berger and Douglas 2009; Campbell 2005; Dawson 2004) and religious authority online (Baffelli, Reader, and Staemmler 2011; Barker 2005; Busch 2011; Campbell 2005; 2007; 2010; Cheong et al. eds. 2012; Cheong, Huang, and Poon 2011). In the last few years, a news term, digital religion, has emerged in a number of publications and conferences to describe the mediation practices of religion online (Campbell ed. 2013; Cheong et al. eds. 2012; Hoover and Enchaibi 2012). For different waves in research on the Internet and religion, see Campbell 2011. Regarding the Japanese context, earlier studies on Japanese religion online include Ikegami and Nakamaki (1996); Inoue ed. (2003); Kurosaki ed. (2000); Tamura (1998); Tosa (1998). In 1998, a research project named the Archive for Religion Information was set up at the Institute for Japanese Culture and Classics at Kokugakuin University. In the following years, other projects were supported by the Japanese Association for the Study of Religion and Society, such as "Jōhō Jidai to Shūkyō" (Information Age and Religion, 1996-98, led by Nakamaki Hirochika, http://jasrs.org/projects/information-age.html) and "Intānetto to Shūkyō" (Internet and Religion, 1998-2001, led by Tamura Takanori, http:// jasrs.org/projects/jasrs-cmc/index.html). These were followed by the project on "Shūkyō Comyunikēshon" (Religious Communication) in 2001, renamed "Shūkyō to Jōhō Gijutsu" (Religion and Information Technology) in 2011. In 1999, the project "Cyber Religion Self-Representation and Self-Understanding of Religious Communities on the Japanese Internet-The WWW as a Source for Japanese Studies" was established at Tübingen University (Germany) and led by Klaus Antoni, Birgit Staemmler and Petra Kienle.

2. Shinrankai emerged out of the Honganji sect in 1958 and was founded by Takamori Kentetsu (born 1929), a former Honganji priest. Until the 1990s, Shinrankai openly attacked Honganji's doctrine and practices and organised protests against the sect (Inoue 2005). Although now the group seems more focused on propagation activities, it also uses the Internet to continue its criticism of Honganji (Fukamizu 2011).

3. In a recent conversation with the webmaster of one of the largest Japanese new religions, it was mentioned that the main request from the group was to do online damage control because of numerous critical websites or defamatory discussions on social media.

4. Japan has one of the highest rates of Internet penetration in the world. In 2014, 86.03 per cent of Japanese population had access to the Internet. See: http://www. internetlivestats.com/internet-users-by-country/. The number of users almost doubled between 2000-2004 (http://www.internetlivestats.com/internet-users/ japan/). According to recent survey, most users access social media both on mobile phones and desktops. The most popular social media are Line, Google+, Facebook and Twitter. See: http://www.soumu.go.jp/iicp/chousakenkyu/ data/research/survey/telecom/2014/h25mediariyou_1sokuhou.pdf. All websites accessed July 23, 2015.

5. http://masanobutaniguchi.cocolog-nifty.com/monologue $2 / 2015 / 07 /$ post4eb7.html. Accessed July 17, 2015.

6. The Facebook account is public: https://www.facebook.com/Seichonoie.President; his Twitter account is: https://twitter.com/seicho_no_ie. Both accessed July 17, 2015.

7. Aum splinter groups are monitored under two new laws introduced in 1999, the Victims' Compensation Law (Higaisha kyūsaihō) and the Organisational

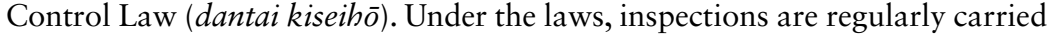


out at the groups' facilities and the groups are required to submit lists of their membership and assets every three months (Wilkinson 2009, 98). The surveillance is revised every three years and it was extended in 2003, 2006, 2009, 2012 and 2015.

8. Although Hikari no Wa members do not refer to Jōyū as a "leader", but rather as a daibyō ("representative"), he is de facto in charge of the group. Therefore, for convenience's sake, I refer to him as such in this chapter.

9. https://twitter.com/joyu_fumihiro. Accessed July 18, 2015.

10. This section is based on Baffelli and Staemmler (2011).

11. My account of Asahara's life is based on Reader (1996 and 2000, 32-60), Shimazono (2001b) and Watanabe (1996).

12. The exact length of his membership is not clear. While Agonshū tries to downplay its influence on Asahara, the fact that he is said to have completed a 1000day religious exercise indicates that he was a member for at least three years (Shimazono 2001b, 23).

13. Aum Shinrikyō's doctrine and publications have been extensively investigated by several scholars. See, for example, Fujita (2008); Inoue and RIRC eds. (2011); Reader (2000a), Shimazono (1995; 1997b; 2001b).

14. A video of Asahara performing the Shaktipat initiation during a TV show is available at: http://www.youtube.com/watch?v=7AkTLeBFXoQ. Accessed July 18, 2015.

15. For further discussions on Aum's turn to violence, see Reader (2000); Shimazono $(1995 ; 2001 b)$.

16. This section is a slightly modified version of my overview of Hikari no Wa for the World Religions and Spirituality Project: http://www.wrs.vcu.edu/profiles/ HikariNoWa.htm. Accessed July 17, 2015; and based on Baffelli (2012).

17. Since 2008, Aleph usually refers to itself as "Aleph" in Roman letters. From 2000 to 2003, the Japanese transcription officially used was Arefu and, from 2003 to 2008, Arêfu. The name Aleph was chosen as the group's name because it implies a new beginning, the creation of something "new": http://www. aleph.to/aleph/qa-01.html\#01 Accessed July 17, 2015.

18. Jōyū Fumihiro's "Outlook on the Aum-Related Incidents" was published on the English version of Aleph's public relations' website at http://english.aleph. to/pr/01.html. Accessed July 17, 2015.

19. http://www.aleph.to/exercise/. Accessed July 17, 2015.

20. Members who were able to achieve higher levels in the hierarchical structure were assigned holy names (höri nēmu), which usually originated from Sanskrit terms.

21. Personal communications and interviews with group representatives, November 2010-January 2011.

22. See: http://www.joyu.jp/hikarinowa/overview/. Accessed July 17, 2105.

23. See: http://www.joyu.jp/hikarinowa/overview/. Accessed July 17, 2105.

24. See: http://www.joyus.jp/hikarinowa/overview/05/0006.html. Accessed July 18, 2015.

25. See: http://www.joyus.jp/hikarinowa/overview/00_1/0030.html. Accessed July 23, 2015.

26. On naikan, see Ozawa de Silva (2006); Shimazono (2015).

27. For a detailed account of the material produced by Aum, see Inoue and RIRC eds. 2011.

28. For other examples of Aum manga, see Schodt (1996); Thomas (2012,134-137).

29. See: http://hikarinowa.net/kyokun/. Accessed July 18, 2015.

30. http://net-dojo.hikarinowa.net/home.html. Accessed July 18, 2015. Dōjō is common Japanese term for "training hall" or "meditation hall". 


\section{New Religions and Offline/Online Interactions}

31. The idea of netto shükyo was expressed by the leader both in an interview with the author (November 2010) and in a blog entry on December 2, 2010 (now deleted).

32. Interview with a representative of the PR office and the webmaster, January 2009.

33. http://hikarinowa.shop-pro.jp/. Accessed July 18, 2015

34. Although several Aum members have confessed their crimes during trials, Asahara has been uncommunicative in court and with his lawyers and has never admitted responsibility for the crimes.

35. Interview with a representative of the PR office and the webmaster, January 2009.

36. The news of Joyū starting to use Mixi was reported in several newspapers and online magazines. See, for example: http://news.livedoor.com/article/detail/ 3070482/. Accessed July 18, 2015.

37. Mixi was launched in 2004 by Kasahara Kenji, initially as a job search and recruiting site. Quickly converted to an invitation-only social networking site, by June 2009, it had around 24 million members, up from 19 million only a year earlier. According to a joint survey carried out by Internet.com and Goo (2008), at the time, 86 per cent of social media users in Japan were using Mixi.

38. http://ameblo.jp/joyufumihiro/. Accessed July 18, 2015.

39. https://www.youtube.com/user/HIKARINOWAMOVIE. Accessed July 18, 2015.

40. http://hikarinowa.net/tv/. Accessed July 18, 2015.

41. As noted earlier, Hikari no Wa remains under surveillance by the authorities, and is subject to legal scrutiny by the security services.

42. A representative of the group's Public Relations Department mentioned to me on several occasions that they didn't mind being seeing as a "boring” group, as this could make people feel safer in approaching them.

43. A Jōyū fan club homepage was created before his release from prison in 1999, but it is no longer available online. See Wudunn (1995).

44. Since 2007, Jōyū has published two books and has been interviewed by several magazines, but in general terms, the movement has not had the balanced public media access it seeks in order to advance its claims of being a respectable and safe movement. 


\section{Conclusions}

\section{Mediation Practices and Reception}

The case studies presented in the previous chapters have shown how mediation practices employed by new religions at the beginning of their formation could impact both the success of a movement and the branding of its image in the public sphere. They also discussed how media reporting could impact a group's image and examined different strategies employed by new religions to respond to criticism. The complex and dualistic relationship between media and new religions is a crucial issue and, as the examples I provided have demonstrated, needs to be understood in the wider context of a group's history and of the perception of religion in contemporary societies. There are also a number of other topics that could be explored in future research in these areas, including comparative studies between Japan and other contexts or between new religions and established religious organisations. Emerging research projects have also starting evaluating whether the impact of a more recent traumatic event, the March 2011 triple disasters, will have any long-lasting impact on representations of religion in the Japanese mass media and on religious organisations' use of media, in particular the Internet (Enomoto 2012; Fujiyama 2011a; 2011b; McLaughlin 2016).

There is also another critical issue that has been largely overlooked in the study of new religions and media in Japan, namely audience response. Increases in membership or in interest in a group may indicate a success in media strategies, while interviews with members may provide some indications about how publications and videos are used in their daily practices. As mentioned in other chapters, many testimonies of new religions' members have claimed they converted after reading leaders' publications, and references to specific publications are often used in dialogues between members. However, to date, very few studies have been done on external audience reception of texts produced by new religions, that is, how readers, viewers and online users appropriate, understand and use materials produced by religious organisations. As noted by Plate (2006), there may be significant differences between a group's intentions, the formal evaluation of texts by consumers, media experts or scholars, and the ways texts are received. Analysing such issues presents several methodological challenges. For example, it is sometimes difficult to have access to places where these texts are 


\section{2}

\section{Conclusions}

discussed. Some discussions on new religions' manga and anime, for example, are available on official websites or social networking site groups created by the religious movement concerned. However, these comments tend to lack objectivity and they are monitored and filtered by the organisations that have set them up. In Chapter Five, I argued that the Internet, with its ability to allow all sorts of people to post things without being fully identified, provides mechanisms for the construction of new forms of religious authority. However, it also allows scope for challenging and undermining such authority. The analysis of Hikari no Wa's use of the Internet also indicated that, differently from other media such as the press, individual users' participation and contributions to the distribution of online content and to the reshaping of leader-member relationships plays a central role.

The ways in which media and religion are related to each other are not stable or predicable because they also depend on audience uses and interpretations. The relationship can indeed be influenced by external forces too, for example, in contexts in which people make use of the open access and anonymity provided by the Internet to ridicule religious groups.

To illustrate this aspect, I would like to conclude this book with a discussion of the reappropriation of Aum Shinrikyō's anime films on video sharing websites, in particular looking at the period when the online presence of Aum's splinter group Hikari no Wa increased, around 2008. In particular, I will focus on videos on video sharing websites such as YouTube and Niko Niko Dōga that parody the anime videos or songs that Aum Shinrikyō once produced and distributed among members and used for proselytism. In Japan, exposés of new religious groups and the open ridicule of their leaders in online communities or forums (Tamura and Tamura 2011) as well as criticism of new religions in the printed press (Dorman 2005; Morioka 1994) are not uncommon, as was discussed in Chapter One. In the case of online parodies of Aum, however, the videos not only make difficult-to-access materials accessible, but also seem to turn what was once a source of fear into a source of both amusement and pointed religious criticism.

\section{VIDEOS}

Among the several user-generated video sharing websites available, I have focused my research on videos uploaded to the most popular services in Japan, ${ }^{1}$ YouTube and Niko Niko Dōga. YouTube, founded by Chad Hurley, Steve Chen and Jawed Karim, was launched in 2005 (Burgess et al. 2009, I). The website offers users a very simple, integrated interface, which allows users to upload and share videos, to link to other users as "friends" and to embed videos in other websites (such as blogs or other social networking services). Niko Niko Dōga (literally: Smiley Video), launched in 2006 and managed by Niwango, is one of the most popular video sharing websites in Japan (Hamasaki et al. 2008). The website presents features similar to 
YouTube, with some important differences. Only registered users can watch videos (registration is free). The main reason for Niko Niko Dōga's popularity is the possibility of overlaying comments directly onto videos, synced to a specific time. This creates a sense of "dialogue" between the videos and the viewers, who can express their opinions on, feelings about and reactions to a specific segment or image. According to Niko Niko Pedia, ${ }^{2}$ almost half of Niko Niko Dōga's users are in their twenties (46 per cent), with an increasing number of teens (30 per cent). Videos posted on Niko Niko Dōga are, for the most part, user-generated. A particularly striking type of video created on Niko Niko are MAD movies (maddo mūbū, also known as Myüjikku anime dogga, Anime Music Video), a term referring to fan-made videos, often mixing together different animation (anime) images and soundtracks. MAD movies are frequently related to the dojin culture, a term usually translated as "club" or "coterie" and referring to group of people sharing similar interests. The word is also used to refer to self-published works, including, for example, dojinshi (amateur manga), ${ }^{3}$ anime, novels and video games.

The videos I am focusing on here were collected during a three-month search period, during June-August 2008. To provide an example, the following figures refer to the number of videos available online on August 15, 2008. The search was carried out on the two websites (YouTube and Niko Niko Dōga) using as keywords the names of the three groups associated with Aum-Aum Shinrikyō, Aleph, Hikari no Wa-and the names of the two leaders-Asahara Shōkō and Jōyū Fumihiro. All words were entered in Japanese only. The search found a total of 247 videos ( 55 for Aum Shinrikyō, 23 for Aleph, 141 for Hikari no Wa, 21 for Asahara Shōkō and seven for Jōyū Fumihiro) for YouTube and 29 videos (23 for Aum Shinrikyō, five for Asahara Shōkō and one for Jōyū Fumihiro) for Niko Niko Dōga. Taxonomically, these videos were divided into five categories:

a. TV/movies: videos from TV news, TV shows, TV documentaries, movies;

b. Groups' materials: videos, animated movies from DVDs and videocassettes produced by the groups for internal use or for proselytism;

c. Groups' online videos: videos created by the groups to be diffused online;

d. Mashups: amateur videos created by users using groups' videos, songs or images;

e. Unrelated: videos not related to the groups.

As shown in Table 6.1, on YouTube, for the keyword Aum Shinrikyō, 30 videos fell into category $a$ (news/movie) and 16 videos fell into category $d$ (mashups), while only five videos were from material produced by the group. Videos from category $a$ included TV news, interviews and documentaries related to the sarin gas attack, the history of the group before 1995 and the official press conferences held by members at the time of significant 
Table 6.1 Videos on YouTube, August 15, 2008.

\begin{tabular}{lccccc}
\hline & $\begin{array}{c}\text { a } \\
\text { News/ } \\
\text { movies }\end{array}$ & $\begin{array}{c}\text { b } \\
\text { Group } \\
\text { material }\end{array}$ & $\begin{array}{c}\text { Group online } \\
\text { video }\end{array}$ & $\begin{array}{c}\text { d } \\
\text { Mashups }\end{array}$ & $\begin{array}{c}\text { e } \\
\text { Unrelated }\end{array}$ \\
\hline Aum Shinrikyō (55) & 30 & 5 & 0 & 16 & 4 \\
Aleph (23) & 8 & 2 & 13 & 0 & \\
Hikari no Wa (141) & 0 & 0 & 141 & 0 & 0 \\
Asahara Shōkō (21) & 13 & 0 & 0 & 3 & 5 \\
Jōyū Fumihiro (7) & 0 & 0 & 7 & 0 & 0 \\
\hline
\end{tabular}

events, such the sarin gas attack in 1995, the restructuring in 2000 and the split in 2007. For Asahara Shōkō, 13 videos were from category $a$ and three were from category $d$. For the keyword Aleph, most videos (13) fell into category $c$, and they were actually videos of the press conferences held by Hikari's no Wa representatives after the split in 2007. For Hikari no Wa and $J \overline{o y} \bar{u}$ Fumihiro, all videos came under category $c$, as they were videos created by the group for its own YouTube channel.

Significantly, almost all the videos related to the keywords Aum Shinrikyo and Asahara Shōkō on Niko Niko Dōga were amateur videos; in particular, they were parodies targeting the image of the ex-leader (see Table 6.2).

The results of the search showed that there were significant differences in how the two leaders were represented on video sharing websites. Furthermore, it showed that Asahara and Aum were targeted by parody videos created and uploaded by users, while videos for the new group Hikari no Wa and its leader were exclusively represented by the group's own material.

Video sharing websites are particularly unstable objects of study (Burgess et al. 2009, 6). Their dynamics change in very short periods of time and the diversity and constant flows of their contents make the selection of material very difficult. These videos are produced fast and consumed fast; they quickly disappear, and then reappear in a different (or identical) form

Table 6.2 Videos on Niko Niko Dōga, August 15, 2008.

\begin{tabular}{lccccc}
\hline & $\begin{array}{c}\text { a } \\
\text { News/ } \\
\text { movies }\end{array}$ & $\begin{array}{c}\text { b } \\
\text { Group } \\
\text { material }\end{array}$ & $\begin{array}{c}\text { Group online } \\
\text { video }\end{array}$ & $\begin{array}{c}\text { d } \\
\text { Mashups }\end{array}$ & $\begin{array}{c}\text { e } \\
\text { Unrelated }\end{array}$ \\
\hline Aum Shinrikyō (23) & 4 & 3 & 0 & 16 & 0 \\
Aleph (0) & 0 & 0 & 0 & 0 & 0 \\
Hikari no Wa (0) & 0 & 0 & 0 & 0 & 0 \\
Asahara Shōkō (5) & 0 & 0 & 0 & 5 & 0 \\
Jōyū Fumihiro (1) & 0 & 0 & 0 & 1 & 0 \\
\hline
\end{tabular}


in the same place (or in a different one), posted by someone else who found them (or received them). The videos considered in this study are produced by amateurs and diffused exclusively online and exchanged within small groups, but with the potential of reaching a wider audience. Authorship is often undeclared, so it is difficult to assess if the people creating these videos are ex-members or have any relation with the religious group. It is also difficult to locate the original videos. They might have been created from tape recording a TV programme on Aum, or they might be part of ex-members' private collections. It is even more difficult, if not impossible, to gauge the variety of available material and how it has been selected by users. As I will discuss later, for example, the majority of parody videos related to Asahara uses only one animation produced by the group. The original is replicated in many copies and reused to produce parodies, which are then copied and pasted on different video sharing websites or discussion forums, creating the impression of a wider variety of material. Finally, searching for the videos could present further challenges. Searching through tags and keywords does not guarantee, indeed, that we will reach all the material available on a certain topic (Burgess et al. 2009), because the videos could have been listed with tags and keywords not including, for example, the name of the group or the leader. However, despite these methodological challenges and the difficulties in keeping pace with rapid developments and changes in video sharing websites, I believe it is important to consider those media products as examples of how religion is represented and consumed online.

\section{ASAHARA ON VIDEO: PARODY}

In order to investigate how Asahara is represented on video sharing websites, I have decided to focus on videos from category $d$, amateur videos created and uploaded by users. The importance of these videos is not only related to their numbers-almost all videos on Niko Niko Dōga concerning Asahara and Aum Shinrikyo come into this category and they were the second largest group on YouTube-but also on the fact that those videos have been created specifically to be uploaded and shared online. In fact, many videos include in their titles or descriptions the indication MAD, or Anime MAD, explicitly indicating a link between the videos and the amateur movies created by anime fans and diffused through video sharing websites. Using techniques common to the style of parody (reiteration, inversion, exaggeration), these parodies reiterate elements from the original text in order to depart from the original, adding new elements and relying "upon intertextual references to other aspects of popular culture, including movies, TV shows, and other ads to create new meanings" (Tryon 2008, 210). The videos can be divided into three subcategories. 


\section{Conclusions}

\section{Example 1: Aum Anime and Non-Aum Background Music}

In these videos, an original anime of Aum is presented with different background music to create a humorous effect, not unlike that created in the American context by a popular user-generated video that turned Mel Gibson's film The Passion of the Christ into a Benny Hill-style farce with a simple change of music and some judicious fast-motion effects. ${ }^{4}$ For example, in the video called Zankokuna sonshi no tēze ("A Cruel Guru's Thesis"), the soundtrack of the popular anime Neon Genesis Evangelion-whose original title is Zankokuna tenshi no tēze ("A Cruel Angel's Thesis")—is substituted in place of the opening song of an anime produced by Aum.

\section{Example 2: Aum Music as the Background for Non-Aum Anime}

In these videos, popular anime images are mixed with Aum's songs, especially if originally sung by the leader. This is the case, for example, with a video called [Asahara Shōkō] Suzumiya Haruhi no sonshi māchi [fuitara poa] ("Suzumiya Haruki [Asahara Shōkō]'s March [If You Laugh, You'll Be Killed]"), in which the opening images of the anime Suzumiya Harubi, based on a series of "light novels" (laito noberu, a type of young adult novel published in Japan) published from 2003, are mixed with a song created by the group, sonshi mächi ("Guru's March"), sonshi being a term used by Aum members to refer to Asahara. The final idiomatic expression (fuitara poa) is repeated in other video titles and can be approximately translated as "if you laugh, you'll be killed". Playing with the meaning of the saying, "Fuitara, make" ("If you laugh, you lose"), the idiom sarcastically refers to poa, a religious practice performed by Aum and representing the most violent expression of the group's interpretation of Buddhist teachings. Originally referring to the Buddhist practice of performing rituals for the dead to help them in the passage to the next spiritual realm, the concept of poa, as discussed in Chapter Five, was widened in Aum doctrine to justify killing as a means of leading a non-believer's spirit to salvation (Reader 2000a, 145-146).

\section{Example 3: Two or More Aum Media}

In these videos, two or more media products of the group are mixed together to create a ridiculous effect, such as, for example, in the video Aum Shinrikyō sonshi songumedorē warattara poa ("Aum Shinrikyō Guru Songs Melody 'If You Laugh, You'll Be Killed'”), which mixes together images of Aum anime and the already-mentioned "Guru's March".

\section{Parody and the Leader's Image}

The interpretation of these videos presents some difficulties. Indeed, many of these parody videos are copied and pasted between YouTube and Niko 
Niko Dōga, and this complicates the assessment of where and when (and by whom) the first mashup was created.

Furthermore, linguistic and specific intertextual references make these videos difficult to decode for a non-Japanese audience. Indeed, as Umberto Eco claims in the introduction to the English translation of Diario Minimo (Misreadings), "Parody, like all comic writing, is linked to space and time" (Eco 1993, 2). The potential of parody heavily depends on the recognition and interpretation of allusions and references to other genres and texts (Gray 2006). The inability of properly decoding the parodic text can result in misunderstanding, especially in a space such as the Internet, where these texts are potentially accessible to everyone. This is the case, for example, with a video called Aum Shinrikyō Anime. The anime was a new copy of a widely reproduced parody video, posted on Niko Niko Dōga with the title Poaemon and on YouTube as Anime MAD Aum Shinrikyō x Doraemon. In the video, images of the anime Chōetsu Sekai ("Transcendental World", produced by Aum) are mixed with the theme song of Doraemon, one of the most popular anime series in Japan, which was created in 1969. The video was also reposted with a title Aum Shinrikyo Anime and with the following description:

Aum Shinrikyo (Supreme Truth), now known as Aleph, founded by Shoko Asahara, is a Japanese religious cult obsessed with the apocalypse. The previously obscure group became infamous in 1995 when some of its members released deadly sarin nerve gas into the Tokyo subway system, killing twelve people and sending more than 5,000 others to hospitals. ${ }^{5}$

As a result, the vast majority of the over 300 comments underneath the video (many of them in English) focused on discussing, criticising and attacking the group for its violence, or introducing more formal comments on religion and violence. The fact that the user(s) who copied and pasted the video-as well as the majority of commentators-missed the parody offers an interesting example of how easily parody can be misunderstood on the Internet, as pointed out by Mikula:

Cyberspace as a medium paradoxically limits parody's political potential, by making it more accessible to 'uninitiated' audiences lacking the cultural knowledge, experience or skills which would make decoding possible.

(Mikula 2003, 173)

If the power of pluritextuality is lost, the parody is lost.

Indeed, to understand parodies of Asahara, one not only needs Japanese language expertise, but also has to be able to understand the specific references to other media, animated movies in particular, and to the group itself. The focus on ridiculing Asahara's "superpowers", for example, is an element often recurring in documentaries and other media portrayals of Aum. 


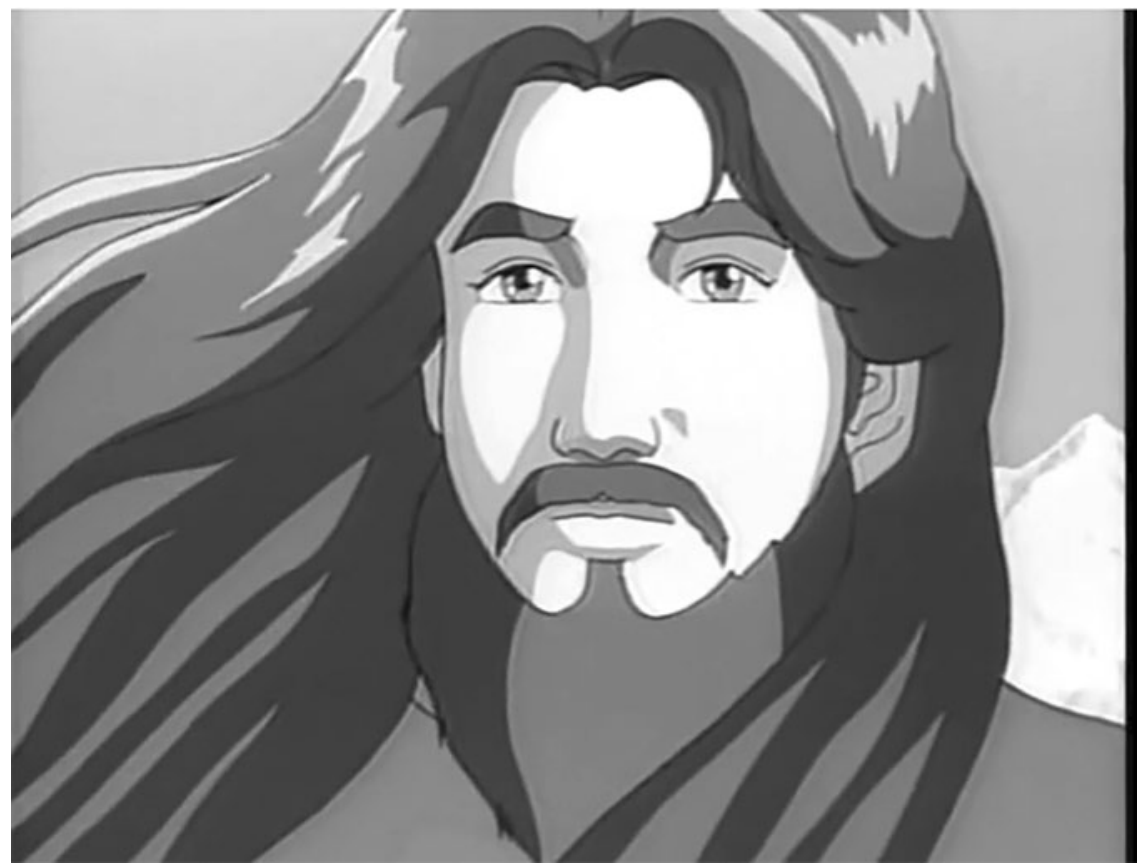

Fig. 6.1 Images of the anime Chōetsu Sekai ("Transcendental World”).

If one looks closely at the material used in the parodies, one will notice that the video most used in parodies is a reproduction of the anime Choetsu Sekai ("Transcendental World"), a series of short episodes produced in 1991 by the Manga Anime Team of Aum Shinrikyō. After the sarin gas attack, the anime was widely discussed in print media and television and was claimed to contain subliminal messages, one of the accusations used by the media to construct an image of Aum and its leader as the "personification of evil" (Reader 2000a, 34) and as a manipulator. The main aim of these parodies is to degrade (Bakhtin 1984) the leader. The (once) untouchable leader becomes a defenceless figure, whose "uncrowning" (Bakhtin 1984) is grounded in the pleasure of associating his image with unusual and unexpected animation characters and songs. Parody can challenge the way we think about authority (Burgess et. al 2009) because it performs an act of "implicit criticism" (Dentith 2000,16). Video sharing website users appropriate a niche product and transform it into a mass product that is mass replicated and mass reproduced. And the "mechanical reproduction", borrowing Benjamin's definition, destroys the "aura" of the leader, no more seen as an object of fear, but as an object of ridicule (Benjamin 1970). Parody can be therapeutic, helping us to distance ourselves from a recent traumatic experience. It can, however, be at the same time both disruptive and conservative. The ridiculing of Asahara, for example, reiterates and preserves the negative image of the 
leader as found in print media, without challenging the representations of the leader as an "evil" man.

\section{Users and Reception}

From a creator's point of view, the mashup videos related to Asahara not only focus on parodying the leader, but also they do it demonstrating fan loyalties to a specific genre (Burns 2009, 75), namely the amateur MAD movies. An important question remains why Aum's anime and songs (which were considered "dangerous" material) have been used for these pleasure-seeking activities. From a genre point of view, the low quality of animated movies by Aum could be one of the reasons. The use of low-quality productions is linked, for example, to the pleasure that B movie fans take in watching low-quality productions and the unintentional humour they create (Voci 2010, 106). Yet unlike harmless B movies, the materials used in these videos were produced by a group that is still seen in the media and by public opinion in Japan as an evil group par excellence. Furthermore, if we consider the statistics related to the average age of Niko Niko Dōga users, who are the creators of many of these videos, their average age is between the late teens and early 20s. It is possible to infer that many of them are aware of the Aum Affair, but have only vague memories of the 1995 events, recollections that are likely to be mainly mediated by the sensationalist accounts found in the mainstream media. More precisely, in order to understand the use and perception of these parodies, we need to take into account that the appropriation of Aum's material can be perceived in different ways, especially by people who clearly remember the shock that the sarin gas attack and associated events provoked in Japan. This mode of similarity can be traced to the so-called "Hitler meme" or "Hitler finds out", a video meme started in 2006. In these videos, new ironic subtitles are added to the dramatic scene of Hitler's fall from power from the German movie Downfall by Oliver Hirschbiegel. Comments and reactions to these videos include both strong disapproval of using material related to serious topics such as the Holocaust and World War Two, and enthusiastic comments praising the videos as funny and clever. While an in-depth analysis of viewers' comments on Aum videos is beyond the scope of this study, it is clear that although the majority of them reiterate the ridiculing of Asahara and his "supernatural ability", some express their disapproval for making fun of this grave and sensitive topic. For some viewers, also, their comments offer an opportunity to relate and share their experiences of the sarin gas attack and their feelings. Several comments claim, "We will never forget that accident", but also express surprise at being able, now, to laugh when watching the parodic videos, thereby confirming the double nature of parody itself, which entertains, but can also be a place to exorcise ghosts:

This contradictory reaction is not, however, just a matter of personal taste. Its roots lie in the bi-directionality of the legitimacy of parody 
itself. The presupposition of both a law and its transgression bifurcates the impulse of parody: it can be normative and conservative, or it can be provocative and revolutionary.

(Hutcheon 1985, 76)

If we compare Asahara's representations on video sharing websites to Jōyū Fumihiro's self-representations online discussed in Chapter 5, it follows that online representations of the two leaders seem to be characterised by continuity, with the online mirroring offline humour and offline celebrity being reproduced in cyberspace. Indeed, Joyū was already a celebrity before starting to use social networking services, and Asahara was an object of parody in print media before becoming the target of online video parodies. In the press and television, for example, Asahara has always, since 1995, been portrayed as the main evil villain of the Aum Affair, while Jōyū, despite the criticism he received for his engagement with the group and his public denial of Aum's involvement in crimes at the beginning, was portrayed as good looking, intelligent and even somehow acceptable.

Moreover, parodic representations of religious groups have been common in Japanese history. In the Edo period, for example, illustrated novels called $k i b y \overline{o s h} i$ were used for satirical portraits of preachers (Kern 2006), while previously, the famous handscroll Chōju giga (Cartoons of Birds and Beasts) by the Tendai Bishop Toba (1053-1140) (Repp 2006), using anthropomorphic animals, presented a satirical representation of the clergy and religious rituals. Similarly, Aum Shinrikyō was the object of ridicule not only online. As discussed by Gardner (2002) in his analysis of senryu (satiric verse form of 7-5-7 syllables) concerning Aum Shinrikyō and published in major Japanese newspapers, "humour has been a central part of the effort to make sense of Aum within Japan" (Gardner 2002, 37). The figure of the leader, in particular, and his claimed abilities (to levitate, for example) as well as the state-like structure started by the group in 1994 were often used as subjects for sarcastic and humorous attacks:

The amount of humour related to Aum is not difficult to account for. Given the general contours of Japanese common sense at the time, Aum and what its members did were unexpected, incongruous, unbelievable, horrifying and-let it be said-just plain strange and weird. While a perception of tragic incongruity quite naturally dominated the understanding of Aum's attack on the subway and the subsequent death and injuries, certain aspects of Aum, such as founder Asahara Shōkō's claim to be able to levitate, struck many as humorous and laughable. The implausible beliefs, hypocrisy, and obvious lies of Aum members gave rise to laughter and became the subject of various forms of ridicule, satire and parody.

(Gardner 2002, 37)

This raises a question of what can be considered "new" in the leaders' representations on video sharing websites. The main difference is that the 
users' role in social networking services and in the "'Do-It-Yourself' (DIY) movement" (Jenkins 2003, 287) of online video sharing websites is much more active than in print media or television, with the user (consumer) being engaged in "re-presenting the contents and adding an interpretation" (Burns 2009, 75). As explained by Mikula, "cyberspace has radically redefined the nature of the narrative, with the hypertextual blurring of the author-reader relationship" (Mikula 2003, 171). In the translation from media to media (from printed media to the Internet) and from leader to leader (from Asahara to Jōyu $)$, the opportunities offered by digital media for people to share their creations with others (Hargittai \& Walejko 2008, 239) have created new ways for materials related to the religious groups and the leader to circulate. The ability of users to "participate in the archiving, annotation, transformation, and circulation of media content" (Jenkins 2003, 286) make more controversial material (for example, the anime portrayed as "dangerous") widely available.

In the case of Aum, it seems that the user-generated content can potentially have the power to de-sacralise religious authority, by mocking the charismatic leader, for example. However, the challenge might be limited to online contexts. As previously discussed, the ridiculing of Asahara online does not seem to affect the image, widely diffused by print media or television, of him being a malevolent perpetrator of evil.

\section{CONCLUDING REMARKS}

In Chapter One, I showed how Araki, a young Aum devotee who suddenly became the group's public relations representative after its top members were arrested in 1995, amidst the trauma of the post-sarin attack period, asked the director Mori to film their everyday activities and thereby help them present themselves to the wider public and show that they were not just a strange and dangerous group. The power of such mediated images can, in such terms, create new images of a religious movement (although, as discussed in Chapters One and Two, Mori's attempt to challenge mainstream representations of Aum has not been successful in Japan)-but images can, as has been demonstrated throughout this book, also be used to create other pictures and meanings. In contrast to the realistic documentary shot by Mori, the parodic videos uploaded by users on video sharing websites such as Niko Niko Dōga demonstrate an alternative power of contemporary media in the hands not of documentary makers, but unnamed online enthusiasts, who are able to use the medium of the Internet to develop new modes of looking at such groups. Rather than producing something that seeks to make sense of and provide a realistic account of a contemporary group, these videos do something quite different: they make fun of a group (admittedly, one associated with terrible deeds). As such, they demonstrate another power of contemporary media: that of ridicule, a theme that may well become increasingly prevalent in future media depictions of religion, 


\section{Conclusions}

especially in online contexts, and one that will need to be taken into consideration in future studies of the links between religion and the media.

In this book, I have investigated how mediated practices can impact the shaping of the identity of a religious organisation at early stage of its formation and its practices. The control of the outputs, or media texts, is central to the new religions-media relationship and, as illustrated by the case studies discussed in previous chapters, this relationship is often ambiguous and dualistic. The final example I have used, that of the parodic reappropriation of Aum's videos online, suggests the potential for the Internet to reshape media-religion discourses in the future and to offer new challenges to religious groups, exposing them not just to the potential hostility of the mass media or rival religious organisations, but to far less controllable and identifiable groups, such as online individual users. It also indicates, via the differing representations of Asahara and Jōyū, how one cannot see the online context as offering just one mode of representation but a multiplicity thereof, while also offering scope for increased interactive engagements between religious groups and audiences, in hostile, parodic and other ways. Responding to these challenges requires a reshaping of the image and communication strategies of religious groups, but also increases possibilities for a more visible presence of religious organisations' voices in the public sphere.

\section{NOTES}

1. See: http://www.alexa.com/topsites/countries/JP. Accessed July 18, 2015.

2. http://dic.nicovideo.jp/. Accessed July 18, 2015.

3. Schodt translates amateur manga created by fans as "fanzine[s]" (Schodt 1996, 37).

4. http://www.youtube.com/watch?v=-gTy2UIHWII. Accessed July 18, 2015.

5. https://www.youtube.com/watch?v=IVnscHsPfR4. Accessed July 18, 2015. 


\section{Bibliography}

'67 Tōkyō Bunkasai Kiroku Iinkai, 1982. Aa Tōkyō bunkasai. Sekai heiwa e no dokyumento. Tokyo: Seikyō shinbun.

Abe, Yoshiya. 1990. "Media and Religion under Church-State Separation Scheme: The Japanese Case." Social Compass 37, 1: 169-178.

Alexander, Bobby C. 1997. "Televangelism: Redressive Ritual within a Larger Social Drama." In Rethinking Media, Religion and Culture, edited by Stewart M. Hoover and Knut Lundby, 194-208. Thousand Oaks, CA: Sage.

Arita Yoshifu. 1991. "'Kokoro no baburu' jidai no 'mondai kyōsō' o kanzen kaibō suru. Ijō zōshoku! 'Kōfuku no Kagaku' Ōkawa Ryūhō no shōtai.” Gendai 8: 141-158.

Asahara Shōkō. 1986. Chōnōryoku: Himitsu no kaihatsuhō. Tokyo: Oumu shuppan.

Asahara Shōkō. 1991. Tatāgata abidanma [Tathagata Abhidhamma]. vol. 1. Tokyo: Oumu Shuppan.

Astley, Trevor. 1995. "The Transformation of a Recent Japanese New Religion: Ōkawa Ryūhō and Kōfuku no Kagaku.” Japanese Journal of Religious Studies 22, 3-4: 343-380.

Astley, Trevor. 2006. "New Religions.” In Nanzan Guide to Japanese Religions, edited by Paul L. Swanson and Clark Chilson, 91-114. Honolulu: University of Hawai'i Press.

Baffelli, Erica. 2000. Dio nella rete: le religioni giapponesi e Internet. M.A. Diss., Università Ca' Foscari di Venezia.

Baffelli, Erica. 2005. Vendere la felicità. Media, marketing e nuove religioni giapponesi. Il caso del Kōfuku no Kagaku. Ph.D. Diss., Università Ca' Foscari di Venezia.

Baffelli, Erica. 2007. "Mass Media and Religion in Japan: Mediating the Leader's Image." Westminster Papers in Communication and Culture 4, 1: 83-99.

Baffelli, Erica. 2010. "Japanese New Religions and the Internet: A Case Study.” Journal for the Academic Study of Religion 23, 3: 255-276.

Baffelli, Erica. 2011. "Charismatic Blogger? Authority and New Religions on the Web 2.0." In Japanese Religions on the Internet: Innovation, Representation, and Authority, edited by Erica Baffelli, Ian Reader, and Birgit Staemmler, 118-135. New York: Routledge.

Baffelli, Erica. 2012. "Hikari no Wa: A New Religion Recovering from Disaster." Japanese Journal of Religious Studies 39, 1: 29-49.

Baffelli, Erica, and Ian Reader. 2011. "Competing for the Apocalypse: Religious Rivalry and Millennial Transformations in a Japanese New Religion." International Journal for the Study of New Religions 2, 1: 5-28.

Baffelli, Erica, and Ian Reader. 2012. "Impact and Ramifications: The Aftermath of the Aum Affair in the Japanese Religious Context." Japanese Journal of Religious Studies 39, 1: 1-28. 


\section{Bibliography}

Baffelli, Erica, Ian Reader, and Birgit Staemmler, eds. 2011. Japanese Religions on the Internet: Innovation, Representation, and Authority. New York: Routledge.

Bakhtin, Mikhail M. 1984. Rabelais and His World. Bloomington: Indiana University Press.

Baldi, Benedetta and Enrico Borello, eds. 1996. I segni ritrovati. La comunicazione pubblicitaria tra persuasione e mercato. Chieri(TO): TTS.

Barker, Eileen. 2004. "What Are We Studying? A Sociological Case for Keeping the 'Nova.”” Nova Religio 8, 1: 88-102.

Barker, Eileen. 2005. "Crossing the Boundary: New Challenges to Religious Authority and Control as Consequence of Access to the Internet." In Religion and Cyberspace, edited by Morten T. Højsggard and Margit Warburg, 67-85. London: Routledge.

Beckerlegge, Gwilym. 2001. "Computer-Mediated Religion: Religion on the Internet at the Turn of the Twenty-First Century?" In From Sacred Text to the Internet, edited by Gwilym Beckerlegge, 219-264. Aldershot: Ashgate.

Beckford, James A. 1985. Cult Controversies: The Societal Response to New Religious Movements. London: Tavistock.

Beckford, James A. 1999. "The Mass Media and New Religious Movements." In New Religions Movements: Challenge and Response, edited by Bryan Wilson and Jamie Cresswell, 103-119. London: Routledge.

Benjamin, Walter. 1970. Das Kunstwerk im Zeitalter seiner technischen Reproduzierbarkeit: drei Studien zur Kunstsoziologie. Frankfurt am Main: Suhrkamp.

Benod, Alexandre. 2010. "Des images pour convaincre. Modernité Japonaise en Perspective.” SFEJ Dec. 2008, Lille, France. Available at https://hal-univ-lyon3. archives-ouvertes.fr/hal-00447961. Accessed July 25, 2015.

Berger, Helen, and Douglas Ezzy. 2009. "Mass Media and Religious Identity: A Case Study of Young Witches?” Journal for the Scientific Study of Religion 48, 3: 501-514.

Berger, Peter L., and Thomas Luckmann. 1966. The Social Construction of Reality: A Treatise in the Sociology of Knowledge. Garden City, NY: Doubleday.

Berndt, Jacqueline. 2008. "Considering Manga Discourse: Location, Ambiguity, Historicity." In Japanese Visual Culture: Explorations in the World of Manga and Anime, edited by Mark MacWilliams, 295-310. Armonk, NY: M. E. Sharpe.

Berthon, Jean-Pierre. 1985. Omoto: Espérance millénariste d'une nouvelle religion japonaise. Paris: Atelier Alpha Bleue.

Berthon, Jean-Pierre. 1991. "Naissance d'une nouvelle religion: la Science du Bonheur." Chambre de Commerce et d'industrie du Japon, FJE49: 33-36.

Berthon, Jean-Pierre. 1997. "Religions historiques et 'nouvelles religions' japonaises: les figures différenciées du renouveau religieux." In Renouveaux religieux en Asie, edited by Catherine Clémentin-Ojha, 113-125. Paris: Presse de l'École Française d'Extrême-Orient.

Berthon, Jean-Pierre. 2011. "Les 'nouvelles religions' japonaises et la mise en scène du religieux." Le Temps des médias 2, 17: 120-130.

Berthon, Jean-Pierre, and Kashio Naoki. 2000. "Les nouvelles voies spirituelles au Japon: état des lieux et mutations de la religiosité." Archives de Sciences Sociales des Religions 109: 67-85.

Boni, Federico. 2002. Il corpo mediale del leader. Roma: Meltemi.

Brasher, Brenda. 2001. Give Me That Online Religion. California: Jossey-Bass.

Breen, John, and Mark Teeuwen, eds. 2000. Shinto in History: Ways of the Kami. Richmond: Curzon.

Bromley, David G. 2004. "Perspective: Whither New Religions Studies: Defining and Shaping a New Area of Study.” Nova Religio 8, 2: 83-97.

Bunkachō, ed. 1977. Shūkyō nenkan: Shōwa gojüichi-nen ban. Tokyo: Gyōsei.

Bunkachō, ed. 1982. Shūkyō nenkan: Shōwa gojūroku-nen ban. Tokyo: Gyōsei. 
Bunkachō, ed. 1986. Shūkyō nenkan: Shōwa rokujū-nen ban. Tokyo: Gyōsei.

Bunkachō Bunkabu Shūmuka. 1987. "Shūkyō dantai no media riyō gaichō.” Shūkyō jihō 77: 34-54.

Burgess, Jean and Joshua Green, eds. 2009. YouTube: Online Video and Participatory Culture. Cambridge, MA: Polity.

Burns, Kelli S. 2009. Celeb 2.0: How Social Media Foster Our Fascination with Popular Culture. Santa Barbara, CA: ABC-CLIO.

Busch, Laura. 2011. "Come to a Correct Understanding of Buddhism: A Case Study on Spiritualising Technology, Religious Authority, and the Boundaries of Orthodoxy and Identity in a Buddhist Web Forum?" New Media and Society 13, 1: 58-74.

Campbell, Heidi. 2005. Exploring Religious Community Online: We Are One in the Network. New York, NY: Peter Lang.

Campbell, Heidi. 2007. "Who's Got the Power? Religious Authority and the Internet.” Journal of Computer-Mediated Communication 12, 3: 1043-1062.

Campbell, Heidi. 2010. "Religious Authority and the Blogosphere." Journal of Computer Mediated Communication 5, 2: 251-276.

Campbell, Heidi. 2011. "Internet and Religion." In The Blackwell Handbook Of Internet Studies, edited by Mia Consalvo and Charles Ess, 232-250. Oxford: Blackwell.

Campbell, Heidi, ed. 2013. Digital Religion: Understanding Religious Practice in New Media Worlds. London: Routledge.

Carneiro, Larissa. 2015. "The Implication of Technology in Mediatization and Mediation Approaches to Religious Studies." Culture and Religion: An Interdisciplinary Journal 16, 1: 51-65.

Casetti, Francesco. 2009. "Filmic Experience." Screen 50, 1: 56-66.

Castells, Manuel. 2001. The Internet Galaxy: Reflections on the Internet, Business, and Society. Oxford: Oxford University Press.

Cheong, Pauline Hope, Shirlena Huang, and Jessie Poon. 2011. "Religious Communication and Epistemic Authority of Leaders in Wired Faith Organizations." Journal of Communication 61, 5: 938-958.

Cheong, Pauline Hope, Peter Fischer-Nielsen, Stefan Gelfgen, and Charles M. Ess, eds. 2012. Digital Religion, Social Media and Culture: Perspectives, Practices, Futures. New York: Peter Lang.

Chilson, Clark. 2004. Hidden Buddhists: How and Why Three Shinshū Confraternities in Japan have been Secretive. Ph.D. Diss., Lancaster University.

Chilson, Clark. 2014. "Cultivating Charisma: Ikeda Daisaku's Self Presentations and Transformational Leadership." Journal of Global Buddhism 15: 65-78.

Chin, Bertha, and Matt Hills. 2008. "Restricted Confessions? Blogging, Subcultural Society and the Management of Producer-Fan Proximity." Social Semiotics 18, 2 : 253-272.

Clark, Lynn Schofield. 2007. Religion, Media and the Marketplace. New Brunswick, NJ: Rutgers University Press.

Clarke, Peter B., ed. 1999. Bibliography of Japanese New Religions: with Annotations and an Introduction to Japanese New Religions at Home and Abroad. Richmond: Curzon.

Cobb, Jennifer. 1998. Cybergrace: The Search for God in the Digital World. New York, NY: Crown Publishers.

Comaroff, Jean. 1994. "Defying Disenchantment: Reflections on Ritual, Power, and History." In Asian Vision on Authority: Religion and the Modern States of East and South-east Asia, edited by Charles Keyes, Laurel Kendall, and Helen Hardacre, 301-314. Honolulu: University of Hawai'i Press.

Couldry, Nick, and Andreas Hepp. 2013. "Conceptualizing Mediatization: Contexts, Traditions, Arguments.” Communication Theory 23: 191-202. 


\section{Bibliography}

Covell, Stephen G. 2005. Japanese Temple Buddhism: Worldiness in a Religion of Renunciation. Honolulu: University of Hawai'i Press.

Csordas, Thomas J. 1997. Language, Charisma and Creativity: The Ritual Life of a Religious Movement. Berkeley: University of California Press.

Davis, Erik. 1998. Techgnosis: Myth, Magic, and Mysticism in the Age of Information. New York: Harmony.

Davis, Winston. 1980. Dojo. Magic and Exorcism in Modern Japan, Stanford, CA: Stanford University Press.

Davis, Winston. 1991. "Fundamentalism in Japan: Religious and Political." In Fundamentalisms Observed, edited by Martin E. Marty and R. Scott Appleby, 782813. Chicago: University of Chicago Press.

Dawson, Lorne L. 2000. "Researching Religion in Cyberspace: Issues and Strategies." In Religion on the Internet: Research Prospects and Promises, edited by Douglas E. Cowan and Jeffrey K. Hadden, 25-54. New York, NY: JAI Press.

Dawson, Lorne L. 2004. "Religion and the Quest for Virtual Community." In Religion Online: Finding Faith on the Internet, edited by Lorne Dawson and Douglas Cowan, 75-92. New York, NY: Routledge.

Dawson, Lorne L., and Jenna Hennebry. 1999. "New Religions and the Internet: Recruiting in a New Public Space." Journal of Contemporary Religion 14, 1: 17-39.

Dayan, Daniel, and Elihu Katz. 1992. Media Events: The Live Broadcasting of History. Cambridge, MA: Harvard University Press.

Dentith, Simon. 2000. Parody. New York, NY: Routledge.

De Vries, Hent. 2001. "In Media Res: Global religion, Public Spheres, and the Task of Contemporary Comparative Religious Studies.” In Religion and Media, edited by Hent de Vries and Samuel Weber, 4-42. Stanford, CA: Stanford University Press.

De Vries, Hent, and Samuel Weber, eds. 2001. Religion and Media. Stanford, CA: Stanford University Press.

Dorman, Benjamin. 2001. “Aum Alone.” Religion in the News 4: 21-22.

Dorman, Benjamin. 2005a. "Mixed Blessings Reactions of Two Japanese NRMs to Postwar Media Portrayals.” Nova Religio 9, 2: 7-32.

Dorman, Benjamin. 2005b. "Pana Wave: The New Aum Shinrikyō or Another Moral Panic?" Nova Religio 8: 83-103.

Dorman, Benjamin. 2005c. "New Religions through the Eyes of Ōya Sōichi, "Emperor" on the Mass Media." Bulletin of the Nanzan Institute for Religion and Culture 29: 54-67.

Dorman, Benjamin. 2012a. Celebrity Gods: New Religions, Media, and Authority in Occupied Japan. Honolulu: University of Hawai'i Press.

Dorman, Benjamin. 2012b. "Scholarly Reactions to the Aum and Waco Incidents." Japanese Journal of Religious Studies 39, 1: 154-176.

Dorman, Benjamin, and Ian Reader. 2007. "Projections and Representations of Religion in Japanese Media." Nova Religio 10, 3: 5-12.

Eco, Umberto. 1962. Opera aperta. Forma e indeterminazione nelle poetiche contemporanee. Milano: Bompiani.

Eco, Umberto. 1979. Lector in fabula. La cooperazione interpretativa nei testi narrativi. Milano: Bompiani.

Eco, Umberto. 1993. Misreadings. San Diego, CA: Harcourt Brace.

Egawa Shōko. 1991a. Kyūseishu no yabō: Oumu Shinrikyō o otte. Tokyo: Kyōikushiryō shuppankai.

Egawa Shōko. 1991b. "Ōkawa Ryūhō 'Tōkyō dōmu 5 man nin shūkai' no bukimi." Shukan Bunshun July 25: 186-189.

Egawa Shōko. 1991c. "Ōkawa Ryūhō yo, anata wa henshitsu shita." Shukan Bunshun September 26: 34-37.

Egawa Shōko. 2000. Tamashii no ryoshū: Oumu jiken wa naze okitaka. Tokyo: Chūō Kōron Shinsha. 
Ehrhardt, George, Axel Klein, Levi McLaughlin, and Steven S. Reed, eds. 2014. Kōmeitō: Politics and Religion in Japan. Berkeley: Institute of East Asian Studies.

Enomoto Kaoru. 2006. "Shinshūkyō no media jissen to sono shūkyōkan." Tōkyō Daigaku Shūkyōgaku Nenpō 23: 37-52.

Enomoto Kaoru. 2011. "NHK shūkyō hōsō no rekishi ni kansuru: Kōsatsu." Tōkyō Daigaku Shūkyōgaku Nenpō 28: 67-88.

Enomoto Kaoru. 2012. "Shūkyōsha to sōsharu media: Higashi Nihon Daishinsai tokini okeru Facebook katsudō o chūshin ni." Tōkyō Daigaku Shūkyōgaku Nenpō 29: 31-47.

Ess, Charles, Kawabata Akira, and Kurosaki Hiroyuki. 2007. "Cross-Cultural Perspectives on Religion and Computer-Mediated Communication." Journal of Computer-Mediated Communication 12, 3: 939-955.

Farley, Maggie. 1995. “Japan Sects Offer Personal Path in Rudderless Society.” Los Angeles Times March 26: A10-A13.

Ferraro, Guido. 1999. La pubblicità nell'era di Internet. Roma: Meltemi.

Feuchtwang, Stephan. 2008. "Suggestions for a Redefinition of Charisma." Nova Religio 12, 2: 90-105.

Fitzgerald, Timothy. 2000. The Ideology of Religious Studies. New York: Oxford University Press.

Forbes, Bruce D., and Jeffrey H. Mahan. 2005. Religion and Popular Culture in America. Berkeley: University of California Press.

Foreign Press Center. 1990. Japan's Mass Media. Tokyo: Foreign Press Center.

Fujita Shōichi. 2008. Shūkyō jiken no uchigawa: Seishin o jubaku sareru hitobito. Tokyo: Iwanami Shoten.

Fujiyama Midori. 2011a. "Shūkyōkai no shinsai shien ga hōdō sarenai riyū 1: Hanshin / Higashi Nihon Daishinsai no hikaku yori.” Tokyo: Shūkyō Jōhō Sentā (Center for Information on Religion), August 22, 2011. Available at http://www. circam.jp/reports/02/detail/id=2007. Accessed July 25, 2015.

Fujiyama Midori. 2011b. "Shūkyōkai no shinsai shien ga hōdō sarenai riyū 2: Hanshin / Higashi Nihon Daishinsai no hikaku yori”. Tokyo: Shūkyō Jōhō Sentā (Center for Information on Religion) August 22. Available at http://www.circam. jp/reports/02/detail/id=2008. Accessed July 25, 2015.

Fukamizu Kenshin. 1994. 'Fukyō keitai no tokusei ni miru Aum Shinrikyō no kyōgi to gaiyō." In Nishinihon no shinshūkyō undō no hikaku kenkyū, Vol. 1, edited by Sakai Nobuo, 57-84. Fukuoka: Kyūshū Daigaku Bungakubu Shūkyōgaku Kenkyūshitsu.

Fukamizu Kenshin. 1996. "Oumu Shinrikyō no pasokon tsūshin: Denshi media no hattatsu to shūkyō kyōdan no henyō.” In Jōhō jidai wa shūkyō o kaeru ka: Dentō shūkyō kara Oumu shinrikyō made, edited by Ikegami Yoshimasa and Nakamaki Hirochika, 185-191. Tokyo: Kōbundō.

Fukamizu, Kenshin. 2007. "Internet Use among Religious Followers: Religious Postmodernism in Japanese Buddhism." Journal of Computer-Mediated Communication 12, 3: 977-998.

Fukamizu, Kenshin. 2011. "The Situation of Japanese Traditional Buddhism in the Web 2.0 Era: Who Attacks and Who Guards the Religion.” In Japanese Religions on the Internet: Innovation, Representation, and Authority, edited by Erica Baffelli, Ian Reader and Birgit Staemmler, 39-61. New York, NY: Routledge.

Fukui, Masaki. 1999. "Kōfuku no Kagaku: The Institute for Research in Human Happiness (IRH)." In A Bibliography of Japanese New Religions: with Annotations and an Introduction to Japanese New Religions at Home and Abroad, edited by Peter B. Clarke, 149-167. Richmond, VA: Curzon.

Fukui, Masaki. 2004. A Study of a Japanese New Religion with Special Reference to Its Ideas of the Millennium: The Case of Köfuku-no-Kagaku. Ph.D. Diss., King's College University of London. 


\section{Bibliography}

Gagné, Isaac. 2014. "Mediating Public Images and Managing Charismatic Authority in Contemporary Japan." Paper presented at 14th European Association of Japanese Studies International Conference, Ljubljana, Slovenia, August 27-30.

Gardner, Richard A. 2001. "Aum and the Media: Lost in the Cosmos and the Need to Know." In Religion and Social Crisis in Japan: Understanding Japanese Society through the Aum Affair, edited by Robert J. Kisala and Mark R. Mullins, 133-162. New York, NY: Palgrave.

Gardner, Richard A. 2002. "The Blessing of Living in a Country Where There Are Senryū!' Humor in the Response to Aum Shinrikyō.” Asian folklore studies 61, 1: 35-75.

Gardner, Richard A. 2005. "Collective Memory, National Identity: Victims and Victimizers in Japan." In Quoting God: How Media Shape Ideas about Religion and Culture, edited by Claire Hoertz Badaracco, 153-172. Waco, TX: Baylor University Press.

Gardner, Richard A. 2008. "Aum Shinrikyō and a Panic about Manga and Anime.” In Japanese Visual Culture: Explorations in the World of Manga and Anime, edited by Mark MacWilliams, 200-218. Armonk, NY: M. E. Sharpe.

Giambra, Danilo. 2015. "Japanese New Religions and the Social Networks." In Asian Religions, Technology, and Science, edited by Istvan Keul, 169-185. London: Routledge.

Gluck, Carol. 1985. Japan's Modern Myths: Ideology in the Late Meiji Period. Princeton, NJ: Princeton University Press.

Goffman, Erving. 1961. Encounters. Two Studies in the Sociology of Interaction. Indianapolis, IN: Bobbs Merrill.

Gray, Jonathan. 2006. Watching with the Simpsons: Television, Parody, and Intertextuality. New York, NY: Routledge.

Grimes, Ronald. 2002. "Ritual and the Media." In Practicing Religion in the Age of Media. Explorations in Media, Religion, and Culture, edited by Stewart M. Hoover and Lynn S. Clark, 219-234. New York, NY: Columbia University Press.

Grimes, Ronald. 2006. Rite out of Place: Ritual, Media, and the Arts. Oxford and New York: Oxford University Press.

Haga, Manabu, and Robert J. Kisala. 1995. “Editors' Introduction. The New Age in Japan.” Japanese Journal of Religious Studies 22, 3-4: 235-247.

Hamasaki, Masahiro, Hideaki Takeda, and Takuichi Nishimura. 2008. "Network Analysis of Massively Collaborative Creation of Multimedia Contents: Case Study of Hatsune Miku Videos on Nico Nico Douga.” In UXTV'08 Proceeding of the 1st International Conference on Designing Interactive User Experiences for TV and Video, 165-168. New York, NY: ACM.

Hardacre, Helen. 1984. Lay Buddhism in Contemporary Japan: Reiyūkai Kyōdan. Princeton, NJ: Princeton University Press.

Hardacre, Helen. 1986. Kurozumikyō and the New Religions of Japan. Princeton, NJ: Princeton University Press.

Hardacre, Helen. 1989. Shinto and the State, 1868-1988. Princeton, NJ: Princeton University Press.

Hardacre, Helen. 2003. "After Aum: Religion and Civil Society in Japan." In The State of Civil Society in Japan, edited by Frank J. Schwartz and Susan J. Pharr, 135-153. Cambridge: Cambridge University Press.

Hardacre, Helen. 2007. "Aum Shinrikyō and the Japanese Media: The Pied Piper Meets the Lamb of God." History of Religion 47, 2-3: 171-204.

Hargittai, Eszter, and Gina Walejko. 2008. "THE PARTICIPATION DIVIDE: Content creation and sharing in the digital age" Information, Communication o Society 11, 2: 239-256.

Hayakawa Kazuhiro. 1991a. "Renzoku tsuikyū. Kyūbōchō suru baburu kyōdan 'Kōfuku no Kagaku' Ōkawa Ryūhō no yabō: Kami o nanori 'yūtopia'buchi agete 3oku en kenkin mezasu shinkō shūdan no 'uragawa'." Friday 34-35, August 23-30: 8-9. 
Hayakawa Kazuhiro. 1991b. "Renzoku tsuikyū. Kyūbōchō suru baburu kyōdan 'Kōfuku no Kagaku' Ōkawa Ryūhō no yabō: Benkyō no dekiru futsū no ko datta gakusei jidai Nakagawa Takashi shōnen o kaeta chichioya to 4sai ne no ani” Friday 36, September 6: 60-61.

Hayakawa Kazuhiro. 1991c. "Renzoku tsuikyū. Kyūbōchō suru baburu kyōdan 'Kōfuku no Kagaku' Ōkawa Ryūhō no yabō: Ōkawa shusai o kenshinteki ni sasaeta toshiue josei ga 'watashi no kangae to chigau' to hanarete itta riyü" Friday, 37, September 13: 64-65.

Helland, Christopher H. 2000. "Online-Religion/Religion-Online and Virtual Communitas." In Religion on the Internet: Research Prospects and Promises, edited by Douglas E. Cowan and Jeffrey K. Hadden, 205-224. New York: JAI Press.

Helland, Christopher H. 2005. "Online Religion as Lived Religion. Methodological Issues in the Study of Religious Participation on the Internet." Heidelberg Journal of Religions on the Internet, 1, 1 [online]. Available at http://archiv.ub.uni-heidelberg. de/ojs/index.php/religions/article/view/380. Accessed July 25, 2015.

Hikari no Wa. 2010. Sanbutsu no ichigenhōsoku, bodaishin to rokuharamitsu: Nijüisseki no shūkyō no kakushin. Tokyo: Hikari no Wa.

Hirono Ryūken. 1992. Agonshū no kenkyū: Kiriyama mikkyō no naijitsu. Osaka: Toho Shuppan.

Hjarvard, Stig. 2008. "The Mediatisation of Religion: A Theory of the Media as Agents of Religious Change.” Northern Lights 6, 1: 9-26.

Højsggard, Morten. 2005. "Cyber Religion: On the Cutting Edge between the Virtual and the Real.” In Religion and Cyberspace, edited by Morten Højsggard and Margit Warbur, 50-64. London: Routledge.

Hoover, Stewart M. 2002. "Introduction: The Cultural Construction of Religion in the Media Age." In Practicing Religion in the Age of the Media: Explorations in Media, Religion and Culture, edited by Stewart M. Hoover and Lynn Schofield Clark, 1-6. New York, NY: Columbia University Press.

Hoover, Stewart M. 2006. Religion in the Media Age. London: Routledge.

Hoover, Stewart M., and Knut Lundby, eds. 1997. Rethinking Media, Religion and Culture. Thousand Oaks, CA: Sage.

Hoover, Stewart M., and Lynn S. Clark, eds. 2002. Practicing Religion in the Age of the Media: Explorations in Media, Religion and Culture. New York, NY: Columbia University Press.

Hoover, Stewart M., and Nabil Echchaibi. 2012. "The Third Spaces of Digital Religion: Working Paper.” Center for Media, Religion, and Culture, University of Colorado, Boulder, CO.

Horie, Norichika. 2011. Supirichuariti no yukue. Tokyo: Iwanami shoten.

Horsfield, Peter G. 2004. "Theology, Church and Media: Contours in a Changing Cultural Terrain." In Belief in Media. Cultural Perspectives on Media and Christianity, edited by Peter Horsfield, Mary H. Hess, and Adán M. Medrano, 23-33. Aldershot, England: Ashgate.

Huffman, James L. 1997. Creating a Public: People and Press in Meiji Japan. Honolulu: University of Hawai'i Press.

Hutcheon, Linda. 1985. A Theory of Parody: the Teachings of Twentieth-Century Art Forms. Urbana: University of Illinois Press.

Ikegami Yoshimasa and Nakamaki Hirochika, eds. 1996. Jōhō jidai wa shūkyō o kaeruka. Tokyo: Kōbundō.

Inamasu Tatsuo. 1992. "Media to shūkyō. Kasō genjitsu ni yoru sekaikan no hen'yō." Sankei shinbun, September 30 evening edition, 6.

Inoue Nobutaka. 1992. Shinshūkyō no kaidoku. Tokyo: Chikuma shobō.

Inoue Nobutaka. 1994. "Masukomi to shinshūkyō.” In Shinshūkyō jiten, edited by Inoue Nobutaka, Tsushima Michihito, Nishiyama Shigeru, Kōmoto Mitsugi, and Nakamaki Hirochika, 516-519. Tokyo: Kōbundō. 


\section{Bibliography}

Inoue Nobutaka. 1997. "Shinshinshūkyō gainen no gakujutsuteki yūkōsei ni tsuite." Shūkyō to Shakai 3: 3-24.

Inoue Nobutaka. 1999. Wakamono to gendai shūkyō: Ushinawareta zahyōiiku. Tokyo: Chikuma Shobō.

Inoue, Nobutaka. 2000. Contemporary Japanese Religion. Tokyo: Foreign Press Center.

Inoue, Nobutaka. 2003. Japanese College Students' Attitudes towards Religion: An Analysis of Questionnaire Surveys from 1992 to 2001. Tokyo: Kokugakuin University.

Inoue Nobutaka ed. 2005. Gendai shūkyō jiten. Tokyo: Kōbundō.

Inoue, Nobutaka. 2012. "Media and New Religious Movements in Japan." Journal of Religion in Japan 1, 2: 121-141.

Inoue Nobutaka and the Religious Information Research Centre, eds. 2011. Jōho jidai no Ōmu Shinrikyō. Tokyo: Shunjūsha.

Inoue Nobutaka, Tsushima Michihito, Nishiyama Shigeru, Kōmoto Mitsugi, and Nakamaki Hirochika, eds. 1994. Shinshūkyō jiten. Tokyo: Kōbundō. (Reduced size edition).

Inoue Nobutaka, Tsushima Michihito, Nishiyama Shigeru, Kōmoto Mitsugi, and Nakamaki Hirochika, eds. 1996. Shinshūkyō kyōdan, jinbutsu jiten. Tokyo: Kōbundō.

Inoue Nobutaka ed. 2003. IT jidai no shükyō o kangaeru. Kyoto: Chūnichi Shinbunsha and Hōzōkan.

Inoue Nobutaka, Komoto Mitsugi, Nishiyama Shigeru and Umetsu Reiji. 1985. “Zadankai 'Shūkyō kaiki?’” Shinri to Sōzō. Tokushū: Shūkyō Kaiki? 24: 2-41.

Ishii Kenji. 1989. "Nihonshūkyō no jōhōka no genjō: Kōdō jōhōka ni okeru kojinka to shūkyō" Tōyōgakujutsu kenyūka 28, 3: 71-93.

Ishii Kenji. 1994. "Fukyō-kyōka media.” In Shinshūkyō jiten, edited by Inoue Nobutaka, Tsushima Michihito, Nishiyama Shigeru, Kōmoto Mitsugi, and Nakamaki Hirochik, 322-331. Tokyo: Kōbundō.

Ishii Kenji. 2007. Dēta bukku: Gendai Nihonjin no shūkyō. Tokyo: Shin'yōsha.

Ishii Kenji. 2008. Terebi to shūkyō: Oumu igo o toinaousu. Tokyo: Chūō Kōron Shinsha. Ishii Kenji. 2010. Baraetika suru shūkyō. Tokyo: Seikyūsha.

Isomae Jun'ichi. 2003. Kindai Nihon no shūkyō gensetsu to sono keifu: Shūkyō / Kokka / Shinto. Tokyo: Iwanami Shoten.

Isomae Jun'ichi. 2005. "Deconstructing 'Japanese Religion': a Historical Survey.” Japanese Journal of Religious Studies 32, 2: 235-248.

Iwasa Yoshiya. 1993. "'Shūkyō' ni manabu māketingu katsudō.(2) Kyōdan no kōkoku puromōshon.” Senden Kaigi, June: 128-134.

Iwasa Yoshiya. 1994. "Shūkyō māketingu no kōzō: Maruchi-nettowākinguzukuri ni chūmoku." Senden kaigi. Tokushū II. Shūkyō no māketingu chikara August: 69-77.

Jenkins, Henry. 2003. “Quentin Tarantino's Star Wars? Digital Cinema, Media Convergence, and Participatory Culture." In Rethinking Media Change: The Aesthetics of Transition, edited by David Thorburn and Henry Jenkins, 281-312. Cambridge, MA: MIT press.

Josephson, Jason Ānanda. 2012. The Invention of Religion in Japan. Chicago: University of Chicago Press.

Jōyū, Fumihiro. 2012. Ōmu jiken 17nenme no kokuhaku. Tokyo: Fusosha.

Katz, Elihu, and Tamar Liebes. 2007. "No More Peace!' How Disaster, Terror and War Have Upstaged Media Events.” International Journal of Communication 1: 157-166.

Kawabata, Akira, and Takanori Tamura. 2007. "Online-religion in Japan: Websites and Religious Counseling from a Comparative Cross-Cultural perspective." Journal of Computer Mediated Communication 12, 3: 999-1019.

Kawakami, Tsuneo. 2008. "Stories of Conversion and Religious Commitment in Japan's New Religions.” Ph.D. Diss., Lancaster University. 
Kawamura Kunimitsu. 1981. "Karisumateki shūkyō shidōsha no keisei o megutte: Sutiguma kara karisuma e." Shūkyō kenkyū 246: 5-6.

Kern, Adam L. 2006. Manga from the Floating World: Comicbook Culture and the Kibyoshi of Edo Japan. Cambridge, MA: Harvard University Asia Center.

Ketelaar, James E. 1990. Of Heretics and Martyrs in Meiji Japan: Buddhism and Its Persecution. Princeton N.J, Oxford: Princeton University Press.

Kienle, Petra, and Birgit Staemmler. 2003. "Self-representation of Two New Religions on the Japanese Internet. Jehovah's Witnesses and Seichō no Ie.” In Japanese Cybercultures, edited by Nanette Gottlieb N. and Mark J. McLelland, 222-234. London and New York: Routledge.

Kimiaki Nishida. 1995. Maindo kontorōru to wa nani ka. Tokyo: Kinokuniya.

Kiriyama Seiyū. 1971. Henshin no genri. Tokyo: Hirakawa shuppan.

Kiriyama Seiyū. 1995. Oumu Shinrikyō to Agonshū. Tokyo: Hirakawa shuppan.

Kiriyama, Seiyū. 2001. The Wisdom of the Goma Fire Ceremony. Tokyo: Hirakawa shuppan.

Kisala, Robert J. 1997. “1999 and beyond: The use of Nostradamus' prophecies by Japanese religions.” Japanese Religions 23, 1: 143-157.

Kisala, Robert J. 1999. Prophets of Peace: Pacificism and Cultural Identity in Japan's New Religions. Honolulu: University of Hawai'i Press.

Kisala, Robert J. 2001a. "Religious Responses to the 'Aum Affair'.” In Religion and Social Crisis in Japan: Understanding Japanese Society through the Aum Affair, edited by Robert J. Kisala and Mark Mullins, 107-132. New York: Palgrave.

Kisala, Robert J. 2001b. "Narrative in the Japanese New Religions." Inter-Religio 40 (Winter): 64-77.

Kisala, Robert J., and Mark R. Mullins, eds. 2001. Religion and Social Crisis in Japan. Understanding Japanese Society through the Aum Affair. New York: Palgrave.

Kita Heiwa Bunkasai Shashinshū Hensan Iinkai, ed. 1985. Seiki no kaitaku: Homare no zenshin. Tokyo: Seikyō shinbunsha, 1985.

Kōdansha Furaidē Zenkoku Higaisha no Kai. 1995. Kibō no kakumei. Tokyo: Kōfuku no Kagaku shuppan.

Kōfuku no Kagaku Kōhōkyoku. 1995. Sutoppu za hea nūdo. Anata no kodomo ga, abunai! Tokyo: Kōfuku no Kagaku shuppan.

“'Kōfuku no Kagaku' no kōkoku keisai o megutte: Media kakusha no 'keisai kijun' to "taiō'" 1991. Senden kaigi November: 74-78.

Kojima Nobuyuki. 2011. “Terebi ga hōjita Oumu Shinrikyō.” In Jōhō jidai no Oumu Shinrikyō, edited by Inoue Nobutaka and RIRC, 226-283. Tokyo: Shunjūsha.

Kokusai Shūkyō Kenkyūjo, ed. 2000. Intānetto jidai no shūkyō. Tokyo: Shinshokan.

Kornicki, Peter. 1998. The Book in Japan. A Cultural History from the Beginnings to the Nineteenth Century. Leiden, Netherlands: Brill.

Kornicki, Peter. 1994. "Public Display and Changing Values: Early Meiji Exhibitions and Their Precursors." Monumenta Nipponica 49, 2: 167-196.

Kumamoto Masaki. 2011. "Shinbunhōdō no naka no Oumu Shinrikyō.” In Jōhō jidai no Oumu Shinrikyō, edited by Inoue Nobutaka and RIRC, 221-244. Tokyo: Shunjūsha.

Kurosaki Hiroyuki. 2006. "Internet bunka no haiburiddosei to jinja Shinto." Nibon bunka to Shinto 3: 59-79.

Kurosaki Hiroyuki. 2007. "Intānetto no naka no shūkyō.” In Shūkyō to gendai ga wakaru hon 2007, edited by Watanabe Naoki, 164-167. Tokyo: Heibonsha.

Kurosaki Hiroyuki, ed. 2000. Denshi nettowākingu no fukyū to shükyō no hen'yō. The Spread of Electronic Networking and the Transformation of Religion. Tokyo: Kokugakuin University.

Kurosaki Hiroyuki, Yoshino Kōichi and Terazawa Shigenori. 2009. "Jōhōka shakai ni okeru shūkyō no shakai kōken.” In Shakai kōken suru shūkyō, edited by Inaba Keishin and Sakurai Yoshihide, 135-157. Kyoto: Sekai Shisōsha. 


\section{Bibliography}

Larsen, Elena. 2001. "Cyberfaith: How Americans Pursue Religion Online.” Available at http://www.pewinternet.org/2001/12/23/cyberfaith-how-americans-pursuereligion-online/. Accessed July 25, 2015.

Lundby, Knut, ed. 2009. Media Logic: Looking for Social Interaction. New York, NY: Peter Lang.

Lynch, Gordon, Jolyon Mitchell, and Anna Strhan, eds. 2011. Religion, Media and Culture: A Reader. London and New York: Routledge.

MacWilliams, Mark. 2000. "Japanese Comics and Religion. Osamu Tezuka's Story of the Buddha." In Japan Pop! Inside the World of Japanese Popular Culture, edited by Timothy J. Craig, 109-137. Armonk, NY: M. E. Shape.

MacWilliams, Mark. 2012. "Religion and Manga." In Handbook on Contemporary Japanese Religions, edited by Inken Prohl and John Nelson, 595-628. Leiden and Boston: Brill.

Maeno Kazuhisa. 1994. "Jōhō sangyō toshite no shūkyō ni miru haitekukomyunikēshon.” Senden kaigi. Tokushū II. Shūkyō no māketingu chikara August: 78-81.

Mahan, Jeffrey H. 2014. Media, Religion and Culture: An Introduction. London: Routledge.

Matsuzawa Masahiro. 1985. "Jōhōka shakai ni okeru shūkyō no ibentoka." Shinri to Sōzō. Tokushū: Shūkyō Kaiki? 24: 73-83.

Maxey, Trent. 2014. The "Greatest Problem": Religion and State Formation in Meiji Japan. Cambridge, MA: Harvard University Press.

McCloud, Sean. 2007. "From Exotic to Brainwashers: Portraying New Religions in Mass Media." Religion Compass 1, 1: 214-228.

McFarland, H. Neill. 1967. The Rush Hour of the Gods: A Study of New Religious Movements in Japan. New York: Macmillan.

McLaughlin, Levi. 2009. Sōka Gakkai in Japan. Ph.D. Diss., Princeton University.

McLaughlin, Levi. 2012. "Did Aum Change Everything? What Soka Gakkai before and during the Aum Shinrikyō Affair Tells Us about the Persistent 'Otherness' of New Religions in Japan.” Japanese Journal of Religious Studies 39, 1: 51-76.

McLaughlin, Levi. 2016. "Hard Lessons Learned: Tracking Changes in Media Presentations of Religion and Religious Aid Mobilization after the 1995 and 2011 Disasters in Japan.” Asian Ethnology 75, 1: page TBD.

Melchiorri, Alessandro. 2002. "La dimensione patemica negli spot." In Trailer, spot, clip, siti, banner. Le forme brevi della comunicazione audiovisiva, edited by Isabella Pezzini, 111-147. Roma: Meltemi.

Melton, Gordon. 2004. "Toward a Definition of 'New Religion.” Nova Religio 8, 1: 73-87.

Meyer, Birgit, and Annelies Moors, eds. 2005. Religion, Media and the Public Sphere. Bloomington: Indiana University Press.

Meyrowitz, Joshua. 1985. No Sense of Place: The Impact of Electronic Media on Social Behavior. New York, NY: Oxford University Press.

Mikula, Maja. 2003. "Virtual Landscapes of Memory." Information, Communication \& Society 6, 2: 169-186.

Mitchell, Jolyon, and Sophia Marriage, eds. 2003. Mediating Religion: Conversations in Media, Religion and Culture. London and New York: T\&T Clark.

Mitchell, Richard. 1963. Censorship in Imperial Japan. Princeton, NJ: Princeton University Press.

Moeran, Brian. 1989. Language and Popular Culture in Japan. Manchester: Manchester University Press.

Morgan, David, ed. 2008. Key Words in Religion, Media and Culture. London: Routledge.

Morgan, David. 2011. "Mediation or Mediatisation: The History of Media in the Study of Religion." Culture and Religion 12, 2: 137-152. 
Mori Tatsuya. 2000. A: Masukomi ga hōdōshinakatta oumu no sugao. Tokyo: Kadokawa bunko.

Mori Tatsuya. 2010. A3. Tokyo: Shūeisha Intānashonaru.

Morioka, Kiyomi. 1994. "Attacks on the New Religions. Risshō Kōseikai and the 'Yomiuri affair'” Japanese Journal of Religious Studies 21, 2-3: 281-310.

Murakami Shigeyoshi. 1970. Kokka Shinto. Tokyo: Iwanami Shoten.

Murakami Shigeyoshi. 1980. Kindai Nihon no shūkyō. Tokyo: Kōdansha.

Nakano Tsuyoshi. 2003. Sengo nihon no shūkyō to seiji. Tokyo: Taimeidō.

NHK Hōsō Yoron Chōsajo, ed. 1979. Nihonjin no ishiki kōzō. Tokyo: Nihon Hōsō shuppankyōkai.

Nihon Shinbun Kyōkai. 1992. The Japanese Press 1992. Tokyo: Nihon Shinbun Kyōkai.

Nihon Shinbun Kyōkai. 1994. The Japanese Press 1994. Tokyo: Nihon Shinbun Kyōkai.

Nijū Isseiki Bunmei Kenkyūkai. 1991. Kore ga "Kōfuku no Kagaku” da! Oshie no subete ga wakaru hon. Tokyo: Akua shuppan.

Nishiyama Shigeru. 1979. "Shinshūkyō no genkyō.” Rekishi kōron 5, 7: 33-37.

Nishiyama Shigeru. 1997. "'Shinshinshūkyō gainen no gakujutsuteki yūkōsei ni tsuite' e no ripurai.” Shükyō to Shakai 3: 25-29.

Nishiyama Shigeru, and Ōmura Eishō, eds. 1988. Gendaijin no shūkyō. Tokyo: Yūhikaku.

Numata Ken’ya. 1987. "Gendai shinshūkyō ni okeru karisuma: Takahashi Shinji to Jīeruei ni kansuru ichikōsatsu.” In Kyōso to sono shūhen, edited by Shūkyō Shakaigaku Kenkyūkai, 70-90. Tokyo: Yūzankaku.

Numata Ken'ya. 1988. Gendai Nihon no shinshūkyō. Osaka: Sōgensha.

Numata Ken'ya. 1995. Shūkyō to Kagaku no neoparadaimu: Shin shinshūkyō o chūshin toshite. Osaka: Sōgensha.

Offner, Clark B., and Henry van Straelen. 1963. Modern Japanese Religion-with Special Emphasis upon Their Doctrines of Healing. Leiden: Brill.

Okada Toshio. 1997. "Firumu wa ikiteiru ka? Moto Oumu animētā no kokuhaku." Quick Japan 3: 202-213.

Ōkawa Ryūhō. 1987. Taiyō no hō: Shinjidai o terasu shaka no keiji. Tokyo: Tsuchiya shoten.

Ōkawa Ryūhō. 1989. Budda saitan. Tokyo: Kadokawa bunko.

Ōkawa Ryūhō. 1990a. Ōgon no hō: Shinbunmei o hiraku shaka no eichi. Tokyo: Kadokawa bunko.

Ōkawa Ryūhō. 1990b. Eien no hō. Tokyo: Kadokawa bunko.

Ōkawa, Ryūhō. 1990c. The Laws of the Sun: The Revelation of Buddha that Enlightens the New Age. Tokyo: IRH Press.

Ōkawa Ryūhō. 1991a. Arā no Daikeikoku. Tokyo: Kōfuku no Kagaku shuppan.

Ōkawa Ryūhō. 1991b. Nosutoradamusu senritsu no Keiji. Tokyo: Kōfuku no Kagaku shuppan.

Ōkawa Ryūhō, 1991c. Eien no Budda: Fumetsu no hikari, ima koko ni. Tokyo: Kōfuku no Kagaku shuppan.

Ōkawa Ryūhō. 1994. Risō kokka Nihon no jōken. Tokyo: Kōfuku no Kagaku shuppan.

Ōkawa Ryūhō. 1997. Taiyō no hō: Eru kantāre e no michi. Tokyo: Kōfuku no Kagaku shuppan.

Ōkawa, Ryūhō. 2001a. The Laws of the Sun: The Spiritual Laws \& History Governing Past, Present \& Future. New York: Lantern Books.

Ōkawa Ryūhō. 2001b. Kiseki no hō Jinrui saisei no genri. Tokyo: Kōfuku no Kagaku shuppan.

O'Leary, Stephen D. 1996. "Cyberspace as Sacred Space: Communicating Religion on Computer Networks." Journal of the American Academy of Religion 64: 781-808.

O'Leary, Stephen D., and Brenda E. Brasher. 1996. "The Unknown God of the Internet." In Philosophical Perspectives on Computer-Mediated Communication, edited by Charles Ess, 233-269. Albany: State University of New York Press. 


\section{Bibliography}

Oohashi, Tsutomu. 1988. "A New Dimension of Ethnographic Image and Social Communication." In Cinematographic Theory and New Dimensions in Ethnographic Films, edited by Paul Hocking and Omori Yasuhiro, 85-110. Senri Ethnological Series, 24. Osaka, Japan: Museum of Ethnology.

Ooms, Emily Groszos. 1993. Women and Millenarian Protest in Meiji Japan: Deguchi Nao and Ömotokyō. Ithaca, NY: Cornell University East Asia Series.

Orcutt, Darby. 2010. "Comics and Religion: Theoretical Connections." In Graven Images: Religion in Comic Books and Graphic Novels, edited by David A. Lewis and Christine Hoff Kraemer, 93-106. New York, NY: Continuum.

Ozawa-de Silva, Chikako. 2006. Psychotherapy and Religion in Japan: The Japanese Introspection Practice of Naikan. London: Routledge.

Ōkawa Ryūhō and Hashimoto Kazunori. 1996-2000. Taiyō no hō, voll.1-6. Tokyo: Kōfuku no Kagaku shuppan.

Ōkawa Ryūhō and Hashimoto Kazunori. 2003a. Ōgon no hō: Seiyōhen. Tokyo: Kōfuku no Kagaku shuppan.

Ōkawa Ryūhō and Hashimoto Kazunori. 2003b. Ōgon no hō: Tōyōhen. Tokyo: Kōfuku no kagaku shuppan.

Ōkawa Ryūhō and Hashimoto Kazunori. 2004. Ōgon no hō: Nihonhen. Tokyo: Kōfuku no Kagaku shuppan.

Ōkawa Ryūhō and Hashimoto Kazunori. 2006. Eien no hō. Tokyo: Kōfuku no Kagaku shuppan.

Pace, Enzo. 1986." L'eroe e le sue gesta.” In La narrazione del carisma, edited by Gustavo Guizzardi, 141-170. Torino: Eri/Rai, VPT.

Palmer, David. A. 2007. Qigong Fever: Body, Memory, and Power in Post-Mao China, 1949-1999. London: Hurst.

Pharr, Susan J., and Ellis S. Krauss. 1996. Media and Politics in Japan. Honolulu: University of Hawai'i Press.

Plate, Brent S. 2003. Representing Religion in World Cinema: Film Making, Myth Making, Culture Making. New York: Palgrave Macmillan.

Plate, Brent S. 2006. Blasphemy: Art that Offends. London: Black Dog Publishing.

Pokorny, Lukas and Franz Winter. 2012. “Creating Utopia': The History of Kōfuku no Kagaku in Austria, 1989-2012, with an Introduction to Its General History and Doctrine." In Studies on Religion in Austria, edited by Hans Gerald Hödl and Lukas Pokorny, Vol. 1, 31-79. Vienna: Praesens.

Porcu, Elisabetta. 2010. "Speaking through the Media: Shin Buddhism, Popular Culture, and the Internet." In The Social Dimension of Shin Buddhism, edited by Ugo Dessì, 209-239. Leiden, Boston: Brill.

Prohl, Inken. 1995. Die Agonshū: Eine Neue Reigion in Japan. Berlin: Freie Universität Berlin, Ostasiatisches Seminar/Japanologie.

Prohl, Inken. 2004. "Solving Everyday Problems with the Help of the Ancestors: Representations of Ghosts in the New Religions Agonshū and World Mate." In Practising the Afterlife: Perspectives from Japan, edited by Susanne Formanek and William LaFleur, 461-483. Wien: Verlag der Osterreichischen Akademie der Wissenschaften.

Prohl, Inken. 2012. "New Religions in Japan: Adaptations and Transformations in Contemporary Society." In Handbook of Contemporary Japanese Religions, edited by Inken Prohl, and John Nelson, 241-268. Leiden, Boston: Brill.

Pye, Michael. 2003. "Modern Japan and the Science of Religion." Method and Theory in the Study of Religion 15: 1-27.

Reader, Ian. 1983. Contemporary Thought in Soto Zen Buddhism: An Investigation of the Publications and Teachings of the Sect in the Light of their Cultural and Historical Context. Ph.D. Diss., University of Leeds.

Reader, Ian. 1990. "Returning to Respectability: A Religious Revival in Japan?" Japan Forum 2, 1: 57-68.

Reader, Ian. 1991. Religion in Contemporary Japan. London: MacMillan. 
Reader, Ian. 1994. “Appropriated Images: Esoteric Themes in a Japanese New Religion.” In Esoteric Buddhism in Japan, edited by Ian Astley, 36-63. Copenhagen and Aarhus: Seminar for Buddhist Studies.

Reader, Ian. 1996. A Poisonous Cocktail? Aum Shinrikyō's Path to Violence. Copenhagen: NIAS Publications.

Reader, Ian. 2000a. Religious Violence in Contemporary Japan: the Case of Aum Shinrikyō. Honolulu: University of Hawai'i Press.

Reader, Ian. 2000b. "Scholarship, Aum Shinrikyō, and Academic Integrity." Nova Religio 3, 2: 368-382.

Reader, Ian. 2002. "Identity and Nationalism in the 'New' New religions: Buddhism as a Motif for the New Age in Japan." In Religion and National Identity in the Japanese Context, edited by Kubota, Hiroshi, Klaus J. Antoni, Johann Nawrocki, and Michael Wachutka, 13-36. Munster: LIT.

Reader, Ian. 2004. "Ideology, Academic Inventions and Mystical Anthropology." Electronic Journal of Contemporary Japanese Studies. Available at http://www. japanesestudies.org.uk/discussionpapers/Reader.html. Accesseed July 25, 2015.

Reader, Ian. 2005a. "Of Religion, Nationalism, and Ideology." Social Science Japan 8, 1: 119-124.

Reader, Ian. 2005b. "Chronologies. Commonalities, and Alternative Status in Japanese New Religious Movements: Defining NRMs outside the Western Cul-deSac.” Nova Religio 9: 84-96.

Reader, Ian. 2011. "Buddhism in Crisis? Institutional Decline in Modern Japan.” Buddhist Studies Review 28, 2: 233-263.

Reader, Ian. 2014. Pilgrimage in the Marketplace. New York: Routledge.

Reader, Ian. 2015. "Japanese New Religions: An Overview." World Religions and Spirituality Project, Virginia Commonwealth University. Available at http://www. wrs.vcu.edu/SPECIAL\%20PROJECTS/JAPANESE\%20NEW\%20RELIGIONS/ Japenese\%20New\%20Religions. WRSP.pdf. Accessed July 25, 2015.

Reader, Ian and George J. Tanabe. 1998. Practically Religious: Worldly Benefits and the Common Religion on Japan. Honolulu: Hawai'i University Press.

Redmond, Sean. 2008. “The Star and Celebrity Confessional.” Social Semiotics 18, 2: 109-114.

Repp, Martin. 2006. "Buddhism and Cartoons in Japan.” Japanese Religions 31, 2: 187-203.

Richardson, James T., and Barend van Driel. 1997. "Journalists' Attitude toward New Religious Movements.” Review of Religious Research: Special Issue: Mass Media and Unconventional Religion 39: 116-136.

Rowe, Mark. 2011. Bonds of the Dead: Temples, Burials, and the Transformation of Contemporary Japanese Buddhism. Chicago: University of Chicago Press.

Sawada, Janine Tasca. 2004. Practical Pursuits: Religion, Politics, and Personal Cultivation in Nineteenth-Century Japan. Honolulu: University of Hawai'i Press.

Schodt, Frederik L. 1996. Dreamland Japan: Writings on Modern Manga. Berkeley: Stone Bridge Press.

Semprini, Andrea. 1997. Analizzare la comunicazione. Come analizzare la pubblicità, le immagini, i media. Milano Franco Angeli.

Senft, Theresa M. 2008. Camgirls. Celebrity and Community in the age of social networks. New York, NY: Peter Lang.

Shimada Hiromi. 1992. Kamisama no tsugō. Kyoto: Hōzōkan.

Shimada Hiromi. 1995. Shinji yasui kokoro: Wakamono ga shin shinshükyō ni hashiru riyū. Tokyo: PHP Kenkyūjo.

Shimazono Sumumu. 1981. "Minzoku shūkyō no kōzōteki hendō to shinshūkyō." Tsukuba daigaku tetsugaku shisō gakkei ronshū 6.

Shimazono, Susumu. 1986. "Conversion Stories and Their Popularization in Japan's New Religions.” Japanese Journal of Religious Studies 13, 2-3: 157-175. 


\section{Bibliography}

Shimazono Susumu. 1987. "Shūgō shūkyōo" In Minkanshinkō chōsa seiri handobukku, edited by Tamamuro Fumio, Miyake Hitoshi, Hirano Eiji, and Miyata Noboru, 169-181. Tokyo: Yūzankaku.

Shimazono Susumu. 1992a. Gendai kyūsai shūkyō ron. Tokyo: Seikyūsha.

Shimazono Susumu. 1992b. Shinshinshūkyō to shūkyō boom. Tokyo: Iwanami shoten.

Shimazono Susumu. 1993. "Shūkyōteki monogatari toshite no taikendan: Reiyūkai-kei kyōdan o rei toshite." In Shükyō no kotoba: Shūkyō shisō kenkyū no atarashii chihei, 118-145. Tokyo: Taimeidō.

Shimazono Susumu. 1994. "Shinshūkyō no gainen to hassei." In Shinshūkyō jiten, edited by Inoue Nobutaka, Tsushima Michihito, Nishiyama Shigeru, Kōmoto Mitsugi, and Nakamaki Hirochika, 2-13. Tokyo: Kōbundō.

Shimazono, Susumu. 1995. "In the Wake of Aum: the Formation and Transformation of a Universe of Belief." Japanese Journal of Religious Studies 22, 3-4: 381-415.

Shimazono Susumu. 1996. Seishin sekai no yukue: Gendai sekai to shinreisei undō. Tokyo: Tokyodō Shuppan.

Shimazono Susumu. 1997a. "Jidai no chōkō o yomitoru: Aru jiki no undō no shūgōtai o 'shin shinshūkyō' to yobu igi." Shükyō to Shakai 3: 30-36.

Shimazono Susumu. 1997b. Gendai shūkyō no kanōsei: Ōmu Shinrikyō to bōryoku. Tokyo: Iwanami shoten

Shimazono Susumu. 2001a. Posutomodan no shinshūkyō: Gendai nihon no seishin jōkyō no teiryū. Tokyo: Tōkyōdō shuppan.

Shimazono, Susumu. 2001b. "The Evolution of Aum Shinrikyō as a Religious Movement." In Religion and Social Crisis in Japan: Understanding Japanese Society through the Aum Affair, edited by Robert J. Kisala and Mark R. Mullins, 19-52. New York: Palgrave.

Shimazono, Susumu. 2004. From Salvation to Spirituality: Popular Religious Movements in Japan. Melbourne: TransPacific Publishers.

Shimazono Susumu. 2010. Kokka Shinto to Nihonjin. Tokyo: Iwanami Shoten.

Shimazono, Susumu. 2015. "From Salvation to Healing: Yoshimoto Naikan Therapy and Its Religious Origins." In Religion and Psychotherapy in Modern Japan, edited by Christopher Harding, Iwata Fumiaki and Yoshinaga Shin'ichi, 150-164. London: Routledge.

Shimazono Susumu and Tsuruoka Yoshio, ed. 2004. "Shūkyō" Saikō. Tokyo: Perikansha.

Shūkyō Shakaigaku Kenkyūkai, ed. 1987. Kyōso to sono shūhen. Tokyo: Yūzankaku.

Skov, Lise. 1995. "Environmentalism Seen through Japanese Women's Magazines." In Women, Media, and Consumption in Japan, edited by Live Skow and Brian Moean, 170-196. Honolulu: University of Hawai'i Press.

Staemmler, Birgit. 2000. "Cyberreligion: First Results of a New Research Project." http://www.uni-tuebingen.de/cyberreligion/dfg/public/staemmler2000.htm (website no longer available).

Staemmler, Birgit. 2009. Chinkon kishin: Mediated Spirit Possession in Japanese New Religions. (Bunka-Wenhua Tuebingen East Asian Studies 7). Hamburg, Germany: LIT.

Staemmler, Birgit. 2011. Seichō no Ie. In Establishing the Revolutionary: An Introduction to New Religious in Japan, edited by Birgit Staemmler and Ulrich Dehn, 141-160. Hamburg, Germany: LIT.

Staemmler, Birgit, and Ulrich Dehn, eds. 2011. Establishing the Revolutionary: An Introduction to New Religious in Japan. Hamburg: LIT.

Stalker, Nancy. 2008. Prophet Motive: Deguchi Onisaburō, Oomoto and the Rise of New Religions in Imperial Japan. Honolulu: University of Hawai'i Press.

Stolow, Jeremy. 2005. "Religion and/as Media." Theory, Culture \& Society 22, 4: 119-145. 
Stout, Daniel A. 2012. Media and Religion: Foundation of an Emerging Field. New York: Routledge.

Stout, Daniel A., and Judith M. Buddenbaum. 1996. Religion and the Mass-media: Audiences and Adaptations. Thousand Oaks, CA: Sage.

Stout, Daniel A., and Judith M. Buddenbaum. 2001. Religion and Popular Culture: Studies on the Interaction of Worldviews. Ames: Iowa State University Press.

Stout, Daniel A., and Judith M. Buddenbaum. 2002. "Genealogy of an Emerging Field: Foundations for the Study of Media and Religion." Journal of Media and Religion, 1, 1: 5-12.

Takahashi Shingo. 1995. "Shinkyō no jiyū to maindo kontorōru." Imago (January): 6-8.

Takahashi, Toshie. 2008. "My Space or Mixi? Japanese Young People's Engagement with Social Networking Sites in Everyday Life." Paper presented at 2008 Conference of the International Communication Association (ICA) http://www. allacademic.com/meta/p_mla_apa_research_citation/2/3/1/8/6/p231869_index. html. Accessed July 25, 2015.

Takeda, Dōshō. 1991. "The Fall of Renmonkyō, and its Place in the History of Meiji-Period Religions." In New Religions: Contemporary Papers in Japanese Religion 2, edited by Inoue Nobutaka, translated by Norman Havens, 25-57. Tokyo: Kokugakuin University.

Takimoto Tarō, and Nagaoka Tatsuya, eds. 1995. Maindo kontorōru kara nogarete: Oumu shinrikyō dakkaishatachi no taiken. Tokyo: Kōyū shuppan.

Tamura, Takanori. 1998. "How Does the Internet Work for Religions Based in Japan?” Nenpō Tsukuba Shakaigaku 10: 21-38.

Tamura Takanori. 2005. "Weburogu-jō no shakaiteki iken ni taisuru masu media no eikyō: topikku to tāminolojī no rendō." Shakai jōhōgaku kenkyū 9, 2: 45-58.

Tamura, Takanori, and Daiyū Tamura. 2011. "Reflexive Self Identification of Internet Users and the Authority of Sōka Gakkai: Analysis of Discourse in Japanese BBS, Ni-channeru." In Japanese Religions on the Internet: Innovation, Representation, and Authority, edited by Erica Baffelli, Ian Reader and Birgit Staemmler, 173-195. New York: Routledge.

Teeuwen, Mark, and Bernard Scheid. 2002. "Tracing Shinto in the History of Kami Worship.” Japanese Journal of Religious Studies 29, 3-4: 195-207.

Tennant, Ella. 1995. "Prophet Motive." Far Eastern Economic Review, March 2, 34-35.

Thomas, Jolyon B. 2009. "Religion and Japanese Film: Focus on Anime." In The Routledge Companion to Religion and Film, edited by John Lyden, 194-213. London: Routledge.

Thomas, Jolyon B. 2012. Drawing on Tradition: Manga, Anime, and Religion in Contemporary Japan. Honolulu: Hawai'i University Press.

Thomas, Jolyon B. 2014. "Religions Policies during the Allied Occupation of Japan, 1945-1952." Religion Compass 8, 9: 275-286.

Thomsen, Harry. 1963. The New Religions of Japan. Tokyo: Charles E. Tuttle Company.

Thomson, Robert. 1991. “Japan Bows to a New God.” Financial Times, December 7-8.

Tosa Masaki. 1998. Intānetto to shūkyō. Tokyo: Iwanami shoten.

Trotta, Mauro. 2002. La pubblicità. Napoli: Esselibri.

Tryon, Chuck. 2008. "Pop Politics: Online Parody Videos, Intertextuality, and Political Participation.” Popular Communication: The International Journal of Media and Culture 6, 4: 209-213.

Tsukada Hotaka. 2010. "Kōfuku no Kagaku no eizō media riyō: Kōfuku jitsugentō, eiga Budda Saitan o chūshin ni." In Shūkyō to Gendai ga wakaru hon 2010, edited by Watanabe Naoki, 74-79. Tokyo: Heibonsha. 


\section{Bibliography}

Tsukada Hotaka. 2011. "Oumu Jiken mae no "Oumuron" shoseki to gakujutsu kenkyū: jānarizumu kara shūkyō kenkyū made.” In Jōhō jidai no Oumu Shinrikyō, edited by Inoue Nobutaka and RIRC, 284-304. Tokyo: Shunjūsha.

Tsukada Hotaka. 2015. Shükyō to seiji no tentetsuten: hoshu gōdō to seikiyō icchi no shükyō shakaigaku. Tokyo: Kadensha.

Tweed, Thomas A. 2006. Crossings and Dwellings: A Theory of Religion. Cambridge, MA and London: Harvard University Press.

van Driel, Barend, and James T. Richardson. 1988. "Print Media Coverage of New Religious Movements: A Longitudinal Study." Journal of Communication 38: 37-61.

Voci, Paola. 2010. China on Video: Smaller Screen Realities. London and New York: Routledge.

Watanabe Manabu. 1996. "Sarin kōgeki no atode Oumu Shinrikyō to Nihonjin." Nanzan Shūkyō Bunka Kenkyūsho 6: 3-19.

Watanabe, Manabu. 1997. "Reactions to the Aum Affair: The Rise of the Anti-Cult Movement in Japan." Bulletin of the Nanzan Institute for Religion and Culture 21: 32-48.

Watanabe, Manabu. 2001. "Opposition to Aum and the Rise of the 'Anti-cult' Movement in Japan." In Religion and Social Crisis in Japan: Understanding the Japanese Society through the Aum Affair, edited by Robert J. Kisala and Mark R. Mullins, 87-105. New York, NY: Palgrave Macmillan.

Watanabe, Manabu. 2005. "Aum Shinrikyō and Its Use of the Media: Five Phases of Development." Bulletin of the Nanzan Institute for Religion \& Culture 29: 42-53.

Watanabe, Masako. 2011. "New Religions- A Sociological Approach.” In Establishing the Revolutionary: An Introduction to New Religious in Japan, edited by Birgit Staemmler and Ulrich Dehn, 69-88. Hamburg, Germany: LIT.

Watanabe Naoki, ed. 2015. Shūkyō to Gendai ga wakaru hon 2015. Tokyo: Heibonsha.

Watts, Jonathan. 1998. "Soccer shinhatsubai. What Are the Japanese Consumers Making of the J. League?" In The Worlds of Japanese Popular Culture: Gender, Shifting Boundaries, and Global Cultures, edited by Dolores P. Martinez, 181201. Cambridge: Cambridge University Press.

Weber, Max. 1946. From Max Weber: Essays in Sociology, edited by H. H. Gerth and C. Wright Mills. New York, NY: University of Oxford Press.

Weber, Max. 1968 [1947]. "The Nature of Charismatic Authority and its Routinization." In On Charisma and Institution Building, edited by S. N. Eisenstadt, 48-65. Chicago: University of Chicago Press.

Wessinger, Catherine. 2012. "Charismatic Leaders in New Religions." In The Cambridge Companion to New Religious Movements, edited by Olav Hammer and Mikael Rothstein, 80-96. Cambridge: Cambridge University Press.

Whelan, Christal. 2007a. Religious Responses to Globalization in Japan: The Case of the God Light Association. Ph.D. Diss., Boston University.

Whelan, Christal. 2007b. "Shifting Paradigms and Mediating Media: Redefining a New Religion as 'Rational' in Contemporary Society.” Nova Religio 10, 3: 54-72.

Wieczorek, Iris. 2002. Neue religiöse Bewegungen in Japan. Eine empirische Studie zum gesellschaftspolitischen Engagement in der japanischen Bevölkerung. Hamburg, Germany: Institut für Asienkunde.

Wilkinson, Gregory. 2009. The Next Aum: Religious Violence and New Religious Movements in Twenty-First Century Japan. Ph.D. Diss., University of Iowa.

Winter, Franz. 2012. Hermes und Buddha. Die neureligiöse Bewegung Kōfuku no Kagaku in Japan. Münster, Germany: LIT.

Wudunn, Sheryl. 1995. “Tokyo Journal; Denying Subway Killings, He Steals Girls' Hearts." The New York Times, May 11. Available at http://www.nytimes.com/ 
1995/05/11/world/tokyo-journal-denying-subway-killings-he-steals-girls-hearts. html. Accessed July 25, 2015.

Yakushi'in Tadashi. 1991. Ōkawa Ryūhō \& Kōfuku no Kagaku: Kyōgi, reigen o kiru! Tokyo: Seiron taimususha.

Yamanaka Hiroshi. 1996. "Mangabunka no naka no shūkyō." In Shōhi sareru "shūkyō", edited by Shimazono Susumu and Ishii Kenji, 158-184. Tokyo: Shunjusha.

Yamashita Akiko. 1997. "Seikimatsu no mirai shūkyō: Kōfuku no Kagakuron.” Deai 45-46: 66-92.

Yokoyama Michiyoshi, and Nishiyama Shigeru. 1988. "Shin shinshūkyō būmu to sono seitai." Chūō Kōron 4: 128-139.

Yonemoto Kazuhiro. 1990. “Tōdaide no Budda, Ōkawa Ryūhō no shinrei semināru!” In Imadoki no kamisama, Bessatsu Takarajima 114, 208-221. Tokyo: JICC.

Yonemoto Kazuhiro. 2000. Kyōso taiho: Karuto wa hito o sukuuka. Tokyo: Takarajimasha.

Yonemoto Kazuhiro, and Shimada Hiromi. 1992. Ōkawa ryūhō no reigen. Tokyo: JICC Shuppankyoku.

Yoshikawa Saburō. 1985a. Nichiren no reigen: Ima issai no shüha o koete. Tokyo: Chōbunsha.

Yoshikawa Saburō. 1985b. Kūkai no reigen. Tokyo: Chōbunsha.

Yoshikawa Saburō. 1985c. Kirisuto no reigen. Tokyo: Chōbunsha.

Yoshikawa Saburō. 1986a. Amaterasu ōmikami no reigen. Tokyo: Chōbunsha.

Yoshikawa Saburō. 1986b. Sokuratesu no reigen. Tokyo: Chōbunsha.

Yoshimoto, Mitsuhiro. 1989. “The Postmodern and Mass Images in Japan.” Public Culture 1, 2: 8-25.

YTV Jōhō Sangyō Kenkyū Gurūpu. 1975. Jōhō sangyō toshite no shūkyō : Sōka Gakkai, Reiyūkai, Tenrikyō, PL Kyōdan, Konkōkyō, Tenshō Kōtaijingū kyō, Dewa Sanzan, Osorayama no zenmen bunseki. Tokyo: Saimaru Shuppankai.

Zaleski, Jeff P. 1997. The Soul of Cyberspace: How New Technology Is Changing Our Spiritual Lives. San Francisco, CA: HarperEdge.

Zenkoku Shuppan Kyōkai/Shuppan Kagaku Kenkyūjo. 2006. 2006 Shuppan shihyō nenpō. Tokyo: Zenkoku Shuppan Kyōkai/Shuppan Kagaku Kenkyūjo. 
This page intentionally left blank 


\section{Index}

Numbers in bold indicate tables, and numbers in italics indicate figures

2Channel 38

A (documentary) 14-16, 25-6, 65n2, 151

advertisement $1,7,32,41 \mathrm{n} 38,59,61$, 136; after 1995 23, 38, 84-5, 112; of Agonshū 41n40, 46, $65,69,71-3,74,76,85$; of Agonshū's Hoshi Matsuri 78-82, 85-6; of Aum Shinrikyō 125; of Eien no Buddha 95-9, 101-2; of Kōfuku no Kagaku 34, 35, 38, 45, 60, 89, 94-7, 93, 96, 103-4, 109-10; in Kōfuku no Kagaku's manga 56-7; newspapers and new religions advertising campaigns 4, 10, 22, 27-9, 97, $31,41 \mathrm{n} 40,62$; nostalgia in 98 ; of Oomoto 30; of Reiyūkai 27; and shinhatsubai 59-60, 67n24; of Sōka Gakkai 1,11n1; see also dentsū; shinhatsubai

advertising campaign see advertisement Āgama sutras 70, 73

Agon Nettowāku Shin Shisutemu 74-6

Agon New System Network see Agon Nettowāku Shin Shisutemu

Agonshū 7, 55, 68-88; and Aum Shinrikyō 7, 24, 117, 139n12; and the Internet 43n63; and media 10, 27, 28, 30, 37, 43n60, 51, 72-3; media strategies after Aum 83-5; and "original Buddhism" 70; and printed media 21, 43n66; rituals and events $30,36,45,52,59,85$, 97, 102; teaching and practices
70-2; and televangelists 38; as "user friendly religion" 46 ; Akira 20 see also Satellite Broadcasting

Aleph 120, 121, 132, 134, 137, 139n17; and the Internet 128-34; and online videos 143, 144, 144 animation movies see anime anime 4, 9, 11n5, 37, 42n51, 42n52, 131, 143; and Aum Shinrikyō 43, 123-4, 125, 142, 146-7, 148 ; chōestsu sekai 148 ; of Kōfuku no Kagaku 29, 34, 35, 45, 46, 61; MAD 145; users' reception 149-51

Aoyama Yoshinobu 23, 135

Araki Hiroshi 14, 15, 39n4, 65n2, 151

Arā no Daikeikoku 64, 93, 94, 109

Arita Yoshifu 23

Asahara Shōkō (Matsumoto Chizuo) 7, 22, 24, 43n66, 60, 84, 117-21, 130-2, 135, 139n12; on the Internet 125,126 ; in online videos $143,144,144$, 145 ; parody of $145-52$; TV appearances 1, 14, 23, 25, 26, $46,126,139 \mathrm{n} 14$

Asabi Shinbun (newspaper) 94, 97, $43 \mathrm{n} 60$

audience reception 141-2, 147, 149-51, 152

Aum affair 9, 40n26, 150; consequences of $28,37,84,149$; as a "turning point" $22-5$

Aum Shinrikyō 1, 7, 8, 12n8, 22-4, 129-40; history and teaching 117-20; on the Internet 10, 
124-7, 125, 126, 127; and

Kōfuku no Kagaku 109-10, 111; manga of $33,57,123,124$; and media $11 \mathrm{n} 5,14-15,28,40 \mathrm{n} 30$, 46, 123; and Nostradamus 38; parodic representations 142-52; tensions with media 64, 89, 114n19; see also Aleph; Asahara Shōkō; Hikari no Wa; Jōyū Fumihiro; MAT

aura $30,50,103,148$

\section{Beat Takeshi 26}

Benjamin, Walter 50, 148

Birthday Festival see goseitansai boom 19, 20, 22, 40n19

broadcasting standard 97

Buddha 71, 77, 122; Ōkawa as reincarnation of $90,92,94$, 95, 99-102, 104, 107, 113n5; see also Buddhism

Buddhism 5, 6, 26, 47, 67n25; in Agonshū 46, 60, 70-2, 73, 74; in Aum Shinrikyō 117, 118, 119, 132; in Kōfuku no Kagaku 92; Nichiren 18; Zen 41n44, 120; see also Buddha

busshari 71, 75, 77

Byakkō Shinkō kai 28

Campbell, Heidi 136

celebrity $64,131-3,135,137,150$

censorship $17,39 \mathrm{n} 9$

charisma $31,55,47-9,114 \mathrm{n} 15$

charismatic authority 48, 51, 112, 136; see also charisma; charismatic leader

charismatic leader $6,47,50,70$, $80,86,110$; body of 100 ; "desecration" of 103-6; as online celebrity 135 ; online interaction 132-5, 137; parody of 145-7, 151; "sacralisation" of $99-103$; as spectacle 100 , 103; "virtualisation" of 111-13; see also charisma; charismatic authority

Chikatetsu Sarin Jiken Higaisha no Kai 22

Chilson, Clark 48

Chino Shōkō see Pana Wave Laboratory and Chino Yuko

Chino True Law see Pana Wave Laboratory
Chino Yuko 6, 40n32; see also Pana Wave Laboratory

Chōetsu sekai 147, 148, 148

chōnōryoku see supernatural powers

Chūo Shinbun (newspaper) 17

comics see manga

communication strategies $7,9,31$, 67n26, 73, 124, 152; of Kōfuku no Kagaku 10, 89, 112; and manga 32

community $10,69,76,81,83,92,102$, 122,127

consumers 40n19, 59, 60, 95, 100, 141, 151

consumption 52, 54, 81, 82, 83, 87

conversion stories $9,15,49,55-8$

Cosmomate see World Mate

Csordas 48

cults $12 \mathrm{n} 12,12 \mathrm{n} 13,22$

daibyō 120, 139n8

Davis, Winston 66n16

Deguchi Nao 6, 30

Deguchi Onisaburō 30, 44

dentō shūkyō 5

Dentsū 72, 67n26, 85, 94

digital religion $138 \mathrm{n} 1$

documentary $14,16,25,26,27,39 \mathrm{n} 4$, $65 \mathrm{n} 1,151$

Dorman, Benjamin 27, 39n11, 39n13, 63

Egawa Shōko 23, 67n33, 108

Eien no Buddha 89, 94, 95-9

Eien no hō. 33, 34, 90

Eiga Shingekibu (Sacred Film Division) $41 \mathrm{n} 46$

El Cantāre 15, 34, 92, 93, 99, 100, 102, 105,107 ; proclamation of 101

El Cantāre Festival 53, 99, 101

entrepreneurship 27, 29, 48-9

The Eternal Buddha see Eien no Buddha

eventification 73

experience $15,26,32,55,90,102$, $105,121,148,149$; of mediated rituals $9,69,76,80,81,82-3$, 87; multi-sensational 56

festivals $7,38,53,66 \mathrm{n} 18,73,80$, 100-2, 111; see also Hoshi Matsuri; goseitansai

Feutchwang 48, 66n 8

films 30, 33n41, 37, 41n46, 42n54, $42 \mathrm{n} 55,43 \mathrm{n} 67,45,72,73,83$, 
143, 144; B movies 149; see also movies; anime

First of the Month Fire Rite see Tsuitachi engi hōshō goma

Friday (magazine) 57, 100, 104, 105, 108, 109, 114n18; see also Kōdansha Friday affair

Fukami Tōshu 41n34

Gekkan gendai (magazine) 104

Genma Taisen 20

genze riyaku (this-worldly benefits; practical benefits) 6,70

GLA see God Light Association

God Light Association (GLA) 6, 11n5, 36, 38, 54, 66n9; and Kōfuku no Kagaku 89, 90, 104, 105, 113n7; use of media metaphor 47, 65n7; "visual sessions" of 37; see also Takahashi Shinji; Takahashi Keiko

The Golden Laws see Ōgon no hō gomagi (wooden sticks) 76, 77, 78, 80, $88 \mathrm{n} 18,88 \mathrm{n} 19,88 \mathrm{n} 20$

goseitansai 94-5, 97, 99, 101-5

Great Anshin/Awaji earthquake 28, $41 \mathrm{n} 42$

Great East Japan Earthquake 28 guru 118-19, 122, 146

haipā shūkyō 12n13

Happy Science see Kōfuku no Kagaku Hardacre, Helen 23

Hatsugoma 69

Hayakawa Kazuhiro 105

heresy see jakyō

hierarchy 118, 136, 137

Hikari no Wa 7, 8, 10, 13n19, 24, 49, 115-40; development and teaching 120-3; and the Internet $64,125,128-34,128$, 129,142 ; and online videos 143, 144, 144; rejection of Aum Shinrikyō 60,135; and religious authority $135-7,139 \mathrm{n} 8$; and social media 37; see also Aum Shinrikyō; Jōyū Fumihiro; offline meetings

Hō no Hana Sanpōgyō 26, 41n35

Hoover, Stewart 3, 17

Hoshi Matsuri (Star Festival), 27, 30, 59, 67n20, 68, 69, 74, 78, 79, 86; descriptions 77-80, 88n21; developments in 1980s 71, 84; in media $73,88,97$; and other

Agonshū's events 71

hyper-religions see haipā shūkyō

Ikeda Daisaku 29, 49, 50-1, 53, 66n12, $66 n 13$

Inoue Nobutaka 11n5, 12n12, 20

inshi jakyō 17, 19, 39n11

Institute for the Research in Human Happiness see Kōfuku no Kagaku

Internet 4, 29, 42, 66, 138, 141; and Agonshū 85; and Aum Shinrikyō 123-8; and Hikari no Wa 10, 128-35; and image control 64; in Japan 138n4; and Kōfuku no Kagaku 112; and live rituals 69; and new religions 8, 37, 115-17; and parody 147, 152; and religion (study of) 137-8n1; and religious leader 50, 111, 135-7, 142, 151; and social media 38, 140n37; see also Mixi; Niko Niko Dōga; social media; YouTube

Ishihara Tsuneji 104, 106

Ishii Kenji 41n41

Ishii Tomoko 117

Itō Shinjo 66n15

Iwasa Yoshiya 27

jakyō 19, 39n10, 109

Japan Commercial Broadcasters Association 97

Jikōson $67 \mathrm{n} 30$

Jiu 63, 67n30

jōhō sangyō ("information industry") $28,41 \mathrm{n} 41$

Jōyū Fumihiro 8, 14, 23-4, 60, 116, $118,122,124,139 n 8,120-1$; as celebrity $133,135-7,140 \mathrm{n} 43$, 140n44, 150-1; and online videos $143,144,144$; and social media 49, 117, 119, 130-5, 150

Kageyama Tamio 100, 105, 106

kami 19, 33, 94, 114n22

karuto see cults

Kibō no kakumei 106-8, 115n18

Kinokuniya bookstore 21

Kiriyama Seiyū (Tsutsumi Masuo) 7 , 37, 69, 70-1, 73, 88n9, 88n24; performing rituals $74,75,77$, $79,83-4$; publications by 24 , $43 \mathrm{n} 66,84$ 


\section{kisei shükyō 5}

Kitamura Sayo 27, 41n36, 63

kōan chōsachō 26

Kōdansha 25, 89, 105, 106, 108-10; see also Kōdansha Friday affair

Kōdansha Friday affair 10, 39, 49, 89, 97, 104-6, 108-10, 111; see also National Association of the Kōdansha Friday Victims; Kibō no kakumei

Kōdansha Furaidē Jiken see Kōdansha Friday affair

Kōdansha Furaidē Zenkoku Higaisha no Kai see National Association of the Kōdansha Friday Victims

Kōfuku no Genri see Principles of Happiness

Kōfuku no Kagaku 1, 6, 10, 13n19, 25, 29, 30, 31, 42n48, 43, 46, 48,49 ; advertising campaign 27, 28, 38, 45, 60, 89, 93, 93-5; advertising of Eien no Buddha ("The Eternal Buddha") 95-9; anime and movies of $11 \mathrm{n} 5$, $34,35,37,61,43 n 55$; attacks on media $64,106-8,108-10$, $114 \mathrm{n} 19$; attacks on other groups 109-10; and Aum Shinrikyō 7, $14,24,26,111$; conflict with press $97,104-5$; control of media $67 \mathrm{n} 35$; and conversion stories 55 ; history and teaching 89-93, 113n7; and the Internet 112, 115, 116, 134; magazines of 32 ; manga of $32,33-4$, 56-7, 106-8; and Nostradamus $43 n 66$; post 1995 111-13; and radio 36 ; and satellite broadcasting 36, 43n60, 69; slogan 94; spectacular events 36, 53-4, 89, 100-3, 114n16; see also Arā no Daikeikoku; Eien no Buddha; Eien no hō; El Cantāre; goseitansai; Kōdansha Friday Affair; Nosutoradamusu Senritsu no Keiji; Ōgon no hō; Ōkawa Ryūhō; Principles of Happiness; Taiyō no hō; Yoshikawa Saburō

Kōmeitō 64, 67n31

Konkōkyō 11, 32, 36, 43n57, 114n22

The Laws of Eternity see Eien no ho The Laws of the Sun see Taiyo no hō maddo mūbi see MAD movies

MAD movies 143,145

magazines $9,17,21,22,42 \mathrm{n} 51$, 120, 123; of Agonshū 73; and conversion stories 55, 58; defamatory reporting in $39 \mathrm{n} 13$, 62, 63, 64, 104, 108; of Kōfuku no Kagaku 32, 91, 110, 112; of new religions $15,31-2,38$, $42 \mathrm{n} 50,43 \mathrm{n} 67,45,65 \mathrm{n} 3$; of Oomoto 6, 11n2, 30-1; religious advertisements in 4, 7, 27, 41, $72,94-7$; reporting about new religions $26,28,46,50,57,89$, 100,140 ; see also individual titles

Mainichi Daily News 46, 73, 76

Mainichi Shinbun (newspaper) 97, 105 manga 9, 42n51, 42n52, 43n67, 142,

143; of Aum Shinrikyō 33, 123, 124; and conversion stories 55-8; of Kōfuku no Kagaku 56-8, 106-8, 113n11, 114n18; and new religions $11 \mathrm{n} 5,32-4$, $43 \mathrm{n} 65,57,72,87 \mathrm{n} 9$

mashups video 143-4, 144, 146

MAT (Manga Anime Team) 32, 123, 148

Matsuzawa, Masahiro 73

media 4; ambivalent relationship with new religions $3,15,17,61$, $65,108,110$; attack from new religions 106-8; and conversion stories 55-8; engagement 39 , 44, 65; external 9, 15-16, 27, $64,111,123,130$; impact on definition of religion 3, 4, 18-20, 40n17; impact on practices and rituals 52-5; for increasing profile and improving image 44-7; internal $8,15,61,62$; multi- 4 , 34,35 ; poly(media) 4 ; religion as 2 ; and religion (study of) $2-3$, $11 \mathrm{n} 3,11 \mathrm{n} 5$; representations 4,24 , 48,123 ; as society watchdog 23 ; use in early stage of formation of religious groups $3,6,7,8,61,73$, 130, 152; views on new religions 17-22, 26-8; see also Internet; magazines; manga; media strategies; "media mix"; print media; newspapers; radio; satellite broadcasting; social media

"media mix" 72,30 
media strategies $1,3,10,16,28,29,38$, 45,46 ; changing over time 7,60 , 61; of Oomoto 30-1; post-1995 $7,9,24$; see also media mediation 48-52, 60, 65, 69, 86, 110, 111,141 ; of religion 2 ; or religion online $138 \mathrm{n} 1$

mediatisation 2, 11n 4

Meiji era (1868-1912) 5, 67n25, 39n3; media and new religions in 17 , $18,22,23$

Meikyō Shinshi (magazine) 18

Meitokusai 69, 86; via satellite broadcasting 74-6

Mixi 49, 116, 117, 130-1, 134, 137, $140 \mathrm{n} 36,140 \mathrm{n} 37$

Mori Tatsuya 14, 16, 25, 27, 41n37

movies see films

$M \bar{u}$ (magazine) 20

Murai Hideo 23, 26, 118, 135

My Birthday (magazine) 20

Nakayama Miki 17, 33, 114n22; see also Tenrikyō

Nakazawa Shin'ichi 24n29

narratives 45, 48; of conversion 9, 15, $55-8$; in manga and anime $42 \mathrm{n} 2$, 56-7, 87n9, 123; media 7, 28, 55

National Association of the Kōdansha Friday Victims 106-8

nationwide virtual temple 74

Net Dōjō 116, 117, 129, 129, 131

Netto dōjō see Net Dōjō

new religions $4,7,10,11 \mathrm{n} 6,43 \mathrm{n} 59$, 45, 48, 51; after 1995 24, 25-6, 111, 113; characteristics 5-7, 71 ; criticism toward $8,14,15$, 104, 108, 142; definition 4-5, 12n12, 39n3, 44; and leaders 13n18, 52, 66n8, 66n9, 70, $136,138 \mathrm{n} 3$; media texts by 4 , 64,95 ; media views of $17-22$, 23, 26-7, 40n17, 62, 67n26; membership $12 \mathrm{n} 13$; numbers $12 \mathrm{n} 8$; periods of development $5,13 \mathrm{n} 7$; reaction to criticism 109-10, 141; testimonies in 55, 57 ; use of the Internet $8,115-$ 17,125 ; use of media $1-2,3,9$, $14,16,28-38,42 \mathrm{n} 54,46$; use of media language 47; use of media (study of) $11 \mathrm{n} 5,41 \mathrm{n} 41$; visibility and image changes 59-60, 61, 65 newspapers $1,4,7,9,11 \mathrm{n} 6,31,45$, 62, 115, 150; coverage of Aum Shinrikyō 23; criticism to new religions 26, 50, 63, 64, 104, 108; and Kōfuku no Kagaku 72, 94, 95, 97, 102, 104, 109, 110; in Meiji 17-18, 21, 22, 39n13; and religious advertising 27 , 34, 41n40; see also individual newspapers

new spiritual movements $5,12 \mathrm{n} 11$, $40 \mathrm{n} 23$

NHK 12n6, 20, 88n12

Nichiren 18, 113n4, 90

Nihon Datsukaruto Kyōkai 22

Nibon minkan hōso renmei see Japan Commercial Broadcasters Association

Nikkei Shinbun (newspaper) 97

Niko Niko Dōga 142, 143, 144, 144, $145,147,149,151$

Nishiyama Shigeru $12 \mathrm{n} 10$

Nostradamus 20, 38, 42n55, 43n66, $43 \mathrm{n} 67,93,94$

Nosutoradamusu Senritsu no Keiji 42n55, 43n66, 93, 94

NTT (Nippon Telegraph and Telephone Corporation) 68, 73

offline meetings $116,117,125,134$ ofu kai see offline meetings

Ogawa Tomoko 100, 105, 106

Ōgon no hō 33, 34, 35, 90

Ōkawa Ryūhō (Nakagawa Takashi) 6, 29, 85, 89-90, 110, 111-13; birthday festival of 99-103; establishment of Kōfuku no Kagaku 91-2; media criticism of 49, 50, 57, 97, 104; performing event 1,31 ; proclamation of divine status 10, 98-102; publications by $66 \mathrm{n} 43,56,93$, $94,113 \mathrm{n} 5,113 \mathrm{n} 10$; reaction to criticism 105, 108-9; retirement from public view 111-13, 134; rivalry with Aum Shinrikyō 7; see also Kōfuku no Kagaku; Kōdansha Friday Affair

Oomoto 19, 39n16, 48; and media $6,11 \mathrm{n} 2,11 \mathrm{n} 5,29-30,31,37$, 43n57, 44, 61

Oumu jiken see Aum affair Oumu Shinrikyō Higaisha no Kai 22 Ōya Sōichi 19 


\section{Index}

Pana Wave Laboratory 6, 40n32

Panawēbu Kenkyūjo see Pana Wave Laboratory

parody 142, 144, 149; of Asahara

Shōkō 145-9, 150, 151; and misunderstandings 147; reception of 149,152 ; of religion 150

performance $26,28,53,66,86$, 114 n 14 ; event 1,55 ; live 38 , $75,76-9,83$; mass $52-3,62$, $67 \mathrm{n} 19$; ritual $9,37,52,54$, 81, 84; screened 76-7, 80, 82; spectacular 53,101, 103, 111; of Takahashi Shinji 54

poa 119, 146

Principles of Happiness 56, 92

print media 11n2, 30, 63, 109, 148, $149,150,151$

propagation activities $9,10,11 \mathrm{n} 2,62$, 93, 123, 138n2

prophecy 41n33, 43n66, 60, 101, 110

Public Security Intelligence Agency (PSIA) see kōan chōsachō

publishing house $6,8,29,30,32,107$, 108; of Agonshū 72, 73; of Aum Shinrikyō 123; of Kōfuku no Kagaku 46, 90, 94, 102, 112, 114n16; see also Kōdansha

radio 4, 7, 9, 43n59; and Agonshū 69, 71, 73; and Aum Shinrikyō 123; and Kōfuku no Kagaku 46, 67, 94, 96, 112; programmes by new religions 5n11, 36, 43n 57; and Taniguchi Masaharu 47, 31

Reader, Ian 5, 20, 46, 70, 78, 83, 84, 87, $88 \mathrm{n} 23,114 \mathrm{n} 19,119$

reigen (spiritual words) 90, 104

Reiyūkai 27, 36

"religion boom" 19, 20, 22

Religious Juridical Persons Law see Shūkyō hōjin hō

Renmonkyō 18-19, 39n12, 63, 109

"return to religion" see shūkyō kaigi

Revolution of Hope, the see Kibo no kakumei

Risshō Kōseikai 36, 38, 41n45, 42n49, 43n60, 43n63, 63, 113n4, $114 \mathrm{n} 22$

ritual; 3, 8, 47, 118; of Agonshū 37, 73-4; indoor 74-6; mediated $9,10,81-2,83$; modes of engagement $10,83,86-7$;

outdoor 77-81; reproducibility of 102 ; and satellite broadcasting $68-9,74,75-81$; as spectacle 52 , $78-9,101-2$; see also satellite broadcasting

ruiji shūkyō 12n12, 17

satellite broadcasting 4, 7, 8, 9, 29, 36, 52; in Agonshū 10, 37, 43n60, 49, 60, 65n $3,69,73-4$; and indoor rituals 75-7; and outdoor rituals 78-81; in Sōka Gakkai 50-1, 66n11

Sect Shinto 19

Seichō no Ie 89, 28, 36, 38, 65n6; and the Internet 116, 37; and printed media $6,29,31$; and radio $11 \mathrm{n} 5$, $43 \mathrm{n} 57,47$

Seikyō Shinbun (newspaper) 31, 45, $65 \mathrm{n} 1$

seishin sekai 20-1, 21, 40n23, 40n25

Senden Kaigi (magazine) 27-8, 97

Shimada Hiromi 24n29, 99, 104

Shimamura Mitsu 18; see also Renmonkyō

Shimazono Susumu 12n12, 55

Shinhatsubai 59-60

shinkō shūkyō $12 \mathrm{n} 12$

Shinnyoen 36, 43n60, 43n62, 61, $66 \mathrm{n} 15$

shinreisei undo 5, 40n23; see also new spiritual movements

shin shinshūkyō 4, 12n10; see also New Religions

shinshūkyō see New Religions

Shinto 5, 18, 19, 37, 53, 88, 121

Shirozukume shüdan see Pana Wave Laboratory

Shugendō 60, 69, 70

Shükan gendai (magazine) 104

Shūkan Sunday (magazine) 65n3, 72-3

Shukkesha 117, 118, 120

shukyō būmu see "religion boom"

Shükyō hōjin hō 12n8, 19, 31, 92, 117

shūkyō kaigi 19, 20

social media 4, 8, 37, 85, 87, 112; Hikari no Wa's use of 132-3, 116, 136-7; and issues of control 64, 138n3; in Japan 115-16, $138 \mathrm{n} 4,140 \mathrm{n} 37$; and religious authority 49, 137; see also Internet 
Sōka Gakkai 29, 31, 38, 45, 48, 66n10, $89,109,113 \mathrm{n} 4$; advertising of $1,11 \mathrm{n} 1,45$; conflict with press 63-4, 114n20; online criticism of 115 ; manga by $32-3,57$; large event by $52-3,62$; and satellite broadcasting $36,43 \mathrm{n} 60$, 50-1, 66n14, 86; see also Ikeda Daidaku; Toda Jōsei

spiritual 34, 47, 71, 113, 122, 146; authority 48, 100, 112; damage 106-7; dialogue 54, 67n22; powers 46,72 ; practices 22 , 57, 87n9, 120; see also new spiritual movements; seishin sekai; reigen

spirituality $17,40 \mathrm{n} 23,122$

Stalker, Nancy 11n5, 48

Star Festival see Hoshi Matsuri

State Shinto 39n14

Sunday Mainichi 46, 64, 105

supernatural 20, 41n3, 52, 120, 135, 149; see also Supernatural powers

supernatural powers $20,87 \mathrm{n} 9,117$, 120, 123

\section{Taishō Nichinichi Shinbun (newspaper)} 30,31

Taiyō no hō 33, 34, 90, 94

Takahashi Keiko 54

Takahashi Shinji 6, 47, 54, 90

Takimoto Tarō 23

Taniguchi Masaharu 6, 47

technology 2, 45, 60-1, 62, 64, 69, 72, 87; impact on leader-member relationship 50-1; impact on ritual 52, 76; new 36, 47, 73, 74, 86; see also media

televangelists $7,11 \mathrm{n} 3,38,73,82$

television $1,4,7,12 \mathrm{n} 6,26,27,31,34$, 38, 40n19, 41n40, 43n59, 63; and Aum 14, 23, 24, 30, 64,
135, 137, 148, 151; compared to satellite broadcasting 76 ; report of Kōdansha Friday Affair 105-6; use by new religions 36 , 43n 57, 73, 75, 94, 96, 97, 102

Tenrikyō 17, 27, 28, 31, 37, 114n22; magazines of 32 ; manga of 33 ; radio and television programmes 36

Tenshō Kōtai Jingukyō 27, 63, 41n36

Thomsen, Harry 5, 41n 44

Toda Jōsei 32-3, 50, 53

Toei Animation 34

Tokyo Shinbun (newspaper) 97

Tsuitachi engi hōshō goma 67n20, $69,70,84,88 \mathrm{n} 14$; via satellite broadcasting 74-6

UFO 20, 134

Utopia 91, 92

video sharing websites $64,132,151$, 142, 144-5, 150; see also Niko Niko Dōga; YouTube

visibility $15,16,32,44,45,59,92$; of Aum Shinrikyō 24-5; Internet impact on 135, 137; and its risks $3,8,9,60-5,102$; of religious leaders 50, 103, 110

Weber, Max 47, 48

Whelan, Christal 6, 65n7

World Mate 26, 36, 41n34, 55

yamabushi 77, 79, 82, 85, 86

Yomiuri Affair 63

Yomiuri Jiken see Yomiuri Affair

Yomiuri Shinbun (newspaper) 63, 97

Yonemoto Kazuhiro 104

Yorozu Chōhō (newspaper) 18-19, 39n13

Yoshikawa Saburō 90

YouTube 112, 142-4 